\title{
SUBTLE INVASIONS: ASPECTS OF SAMOAN WOMEN'S WARTIME EXPERIENCES
}

SAUI’A LOUISE MARIE TUIMANUOLO MATAIA-MILO

A THESIS SUBMITTED TO THE VICTORIA UNIVERSITY OF WELLINGTON IN FULFILMENT OF THE REQUIREMENTS FOR THE DEGREE OF DOCTOR OF PHILOSOPHY IN HISTORY

VICTORIA UNIVERSITY OF WELLINGTON 


\section{Acknowledgements}

I would like to express my sincere thanks and gratitude to my supervisors, Adrian Muckle, and Charlotte Macdonald for all your assistance. I thank you most sincerely for your patience, interest, and immense knowledge that guided and helped me through this research. I could not have imagined having better advisors and mentors for this journey.

I acknowledge the scholarship award under the Memorandum of Understanding between the National University of Samoa and Victoria University that enabled me to pursue this study. I also received financial assistance from the Victoria Doctoral Hardship Scholarship and Victoria Doctoral Submission Scholarship.

I would also like to express my deepest appreciation to all my research participants (age 83-105 years), in Upolu, Manono, Savai'i, Tutuila and Manu'a, and in Auckland. You graciously agreed to be interviewed, to contribute and to share your wartime life stories. You are the reason I set out to find answers. Your war experiences have become the core of this thesis. Without you this study would not have been possible. I know most of you have passed on to the spirit world, but your wisdom will strengthen the next generation of Samoan women.

A number of people have contributed their services to improve the quality of this thesis, notably the VUW Librarians Justin Cargill and Tony Quinn, the staff of the New Zealand National Library/Alexander Turnbull Library and Archives New Zealand. A note of gratitude also goes to Father Ioane Ono for giving me permission to look at the Roman Catholic Archdiocese of Samoa-Apia Archives at Vailima. Grace Millar has been a great help in reading and formatting the manuscript. Special thanks also go Judith Bennett who allowed me to access some of the US archives she collected for her project. Thank you also to a small army of friends, here in New Zealand, Pago Pago and Apia that I could access via private messages on social media, who helped me with retaking photos I missed, clarifying names, and attending funerals on my behalf.

Special thanks also goes to Dr. Lizzie Towl of the Faculty of Graduate Research and her 'Shut Up and Write' sessions every Wednesday mornings. I met many awesome 
people in this group, whom I shared this journey with especially, Mickey, Evan, Ha, Corina and Nancy. Thanks for being my writing buddies.

There were many people along the way who welcomed me into their homes to live or to rest a while during the fieldwork in American Samoa: Mulinu'u Leaupepe and Manino Salamo, Ruby Ripley, and I'aulualo Folau Solofa. I am grateful also to the descendants of Tui Manu'a Elisara, Reverend Filoiali'i (EFKAS) and families, for accepting me, a stranger, into their home.

I would like to acknowledge the love and support of my families in New Zealand and in Samoa. I am extremely grateful to my inlaws in Auckland, New Plymouth and Hamilton for your support; and thank you also to my brother Leslie and his family, especially Rosalini, Vaauli, Nicholas and Lucas, for putting a smile on my face everytime you call.

I le agaga fiafia, e momoli fo'i le faafetai tele male faamalo i o'u aiga pele, uso ma tuagane i lau tapuaiga, faapea si ou tina, Rosalie Taioalo Vaauli Mataia. O lau lagolago, o fautuaga sa faamalosiau ia te au, ua afua ai le faai'uina manuia o a'u taumafaiga. Faafetai tele mo alofaaga momolipo, ma ia faamanuia atu pea le Ali’i ia te oe. Ia tatou faafo'i pea le vi'iga ma le faamanu i le Atua soifua.

Finally, a special thanks to my husband, Sulutumu Taiatu Sasa Milo. Patience is indeed one of your greatest virtues. This is also your work. You listened to my ramblings before they became ideas. Your weird humour kept me sane and your positive thinking inspired me to keep going. I am glad I shared this journey with you. Thank you for believing in me. Elalelei la'u pele!

This thesis is dedicated to all the women of Samoa who lived through the Second World War. Your memories have become my memories, and through this thesis they will be the next generations' memories. Faafetai alofa! 


\begin{abstract}
During World War Two the peaceful "occupation" of the Samoa Islands by US Forces combined with existing colonial conditions to transform the lives of Samoans in important yet also subtle ways. Drawing on thirty two oral history interviews and the papers of the colonial administrations this thesis examines the wartime lives of Samoan women. Their accounts of their experiences reveal how they understood the war at the time and after years of life experience. Using approaches from social history and women's history this thesis illustrates women's agency in finding ways to manage the new social contexts and situations created by the war.
\end{abstract}

The central argument of this thesis is that it was the ordinary business of negotiating daily life during the war that engaged and normalised social changes. These mundane everyday acts were significant historical moments that wove new and unique motifs into the tapestry of Samoan women's history. The war brought to Samoa a multitude of American servicemen who saw Samoa through a 'romantic' lens as an arcadia of unrestrained social mores. In contrast, through this research Samoan women reveal their wartime experiences in their own words. The women's narratives indicate that the war interrupted lives in many ways causing them to rethink their roles in response to the changes.

The four areas of Samoan women's lives that this thesis examines are their roles in their families and communities, their involvement with the churches, their engagement with wartime popular culture and lastly their wartime sexual encounters. The discussion opens with a portrait of Samoan society during the 1920s and 1930s, depicting the social and political forces that shaped women's lives and influenced their understandings of their wartime experiences. This discussion highlights how colonial entanglements had a bearing on the different trajectories that women's lives took during the war. The thesis then turns to explore the arrival of the war, examining the women's initial experiences and reactions with a particular focus on what they learnt from their experiences and how they adapted to change in the context of their communities and families. The study finds that social transformation was a response to the war's disruption of physical and cultural space and the critical structures and ideologies that are central to Samoans' way of life. 
The second part of this enquiry examines how wartime circumstances affected Samoan women's sometimes tense relations with the Christian churches. The churches occupied a central place in Samoan society as a provider of both spiritual nurture and secular education for women during the war years, so they deserve specific attention. Wartime conditions created opportunities that expanded and rejuvenated the scope of Samoan women's agency which had been marginalised and narrowed by Christian influence before the war. At the same time, the war heightened the pre-war tensions between Samoan women's agency and the power of the churches. Despite the clergy's reluctance, the churches provided spaces in which American troops socialised with the Samoan population, creating social situations that were difficult to control.

The third area analyses Samoan women's engagement with wartime popular culture and how the consumption of introduced material culture galvanised their autonomy and enabled them to tailor social transformation to suit their personal perceptions. Wartime popular culture in its many forms contributed to the rapid absorption of new ideas and the adaptation of cultural practices. Women's engagement with this popular culture resulted in 'on the ground changes' that stimulated social transformation and which should be appreciated as significant historical moments in their own right.

The fourth area of discussion investigates Samoan women's wartime sexual encounters. The perception that Samoan women's sexual encounters with American servicemen were characterised by an unrestrained morality on their part ignores other factors that shaped these encounters, including violence and their own bodily knowledge and preparedness. This study shows that Samoan women had a variety of sexual encounters during the war and their narratives speak volumes about the pains of such life-changing moments.

There was no single or archetypal wartime experience. The thirty two interviewees experienced the war in different parts of the Samoa islands and their social and political alignment has influenced their perceptions and understanding of their wartime lives. The social transformation brought by the war involved considered responses from the women who sought to balance personal and family interests and Samoan values. Exploring the women's wartime lives reveals their resilience and their ability to overcome difficulties and effect change for the better of their community. 


\section{Table of Contents}

Acknowledgements

Abstract $\quad$ iii

Table of Contents $\quad \mathrm{v}$

List of Figures vi

List of Tables vi

List of Abbreviations $\quad$ vii

Chapter One. Introduction: Situating Samoan Women's World War II Experiences 1

Chapter Two. Lesolosolou - Samoa on the eve of the Second World War 42

$\begin{array}{ll}\text { Chapter Three. The War Arrives in Samoa } & 78\end{array}$

Chapter Four. Samoan Women and the Churches during the War 111

Chapter Five. Consuming Wartime Pleasures: Samoan Women's Engagement with

$\begin{array}{ll}\text { Wartime Popular Culture } & 138\end{array}$

Chapter Six. Samoan Women’s Wartime Sexual Encounters 173

$\begin{array}{ll}\text { Chapter Seven: Conclusion } & 210\end{array}$

Appendix 1: Participant Information Sheet 216

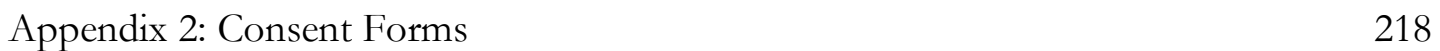

Appendix 3: Questions for Oral History Interviews 220

$\begin{array}{ll}\text { Bibliography } & 231\end{array}$ 


\section{List of Figures}

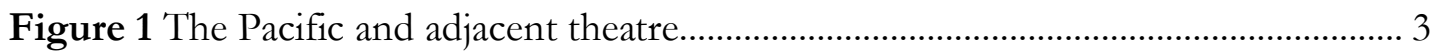

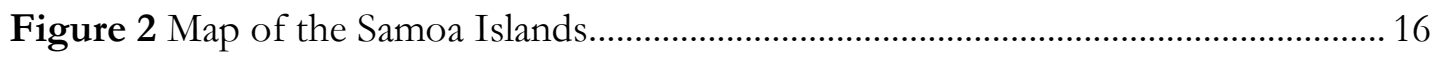

Figure 3 Location of interviewees during the Second World War................................... 30

Figure 4 Location of interviewees during the interview process in 2014 ......................... 31

Figure 5 M. M. Jeanne D’Arc at Makogai, Fiji, with Samoan Lepers, circa the 1940s .. 46

Figure 6 Samoan Hospital, Motootua circa early 1940s. 60

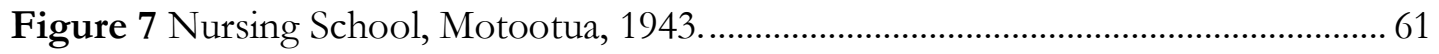

Figure 8 Drama: Students of a Catholic School in the 1930s or early 1940s................ 141

Figure 9 Students of the SMSM Convent School, Moamoa, in the late 1930s............ 143

Figure 10 Unidentified Samoan women. ………........................................................ 144

Figure 11 Perpetual Vows at Moamoa .............................................................................. 145

Figure 12. Snippets of Samoan women's style of dress from the 1930s, 50s and 60s . 146

Figure 13. Charmosan Face Powder Advertisement ........................................................ 148

Figure 14 The Cheeky Dances? Entertainment at the Pearl of the Pacific. .................... 183

Figure 15 An American Serviceman and a young Samoan girl ..................................... 188

\section{List of Tables}

Table 1 Ethnic Profile of Western Samoa, 1942 


\section{List of Abbreviations}

\begin{tabular}{|c|c|}
\hline ANZ & Archives New Zealand \\
\hline ASE & Armed Services Edition \\
\hline ATL & Alexander Turnbull Library \\
\hline CA & Chief Administrator \\
\hline $\mathrm{CD}$ & Contagious Diseases \\
\hline $\mathrm{CMO}$ & Chief Medical Officer \\
\hline DHPG & Deutsche Handels-und Plantagen-Gesellschaft \\
\hline GI & $\begin{array}{l}\text { ‘Government Issue/ General Issue/ Galvanised Iron’ - a noun used to } \\
\text { describe the US Marines. }\end{array}$ \\
\hline LDS & Church of Latter Day Saints \\
\hline LMS & London Missionary Society \\
\hline NARA & National Archives and Records Administration \\
\hline NZRE & New Zealand Reparation Estate \\
\hline OMPA & Oceania Marist Papers Archives \\
\hline $\mathrm{RC}$ & Roman Catholic \\
\hline SDA & Seventh Day Adventist \\
\hline SMSM & Missionary Sisters of the Society of Mary (Suore Missionarie della \\
\hline & Societa Di Maria) \\
\hline STD & Sexually Transmitted Disease \\
\hline US & United States \\
\hline VD & Venereal Diseases \\
\hline
\end{tabular}




\section{Chapter One. Introduction: Situating Samoan Women's World War II Experiences}

Three years ago, when interviewing Samoan women about World War II, I noticed that their discussions were punctuated with sarcastic gestures, raised eyebrows and resounding silences. Such performances emphasised the indignity that the memory most closely associated with Samoan women's wartime experiences was that of 'O Keige Samoa ma a lakou kamai maligi” - 'Samoan women and their baby marines'. ${ }^{1}$ Several members of the generation born immediately after the war relayed this memory in a way that denoted a criminal sentencing for a wartime offence. People do not speak directly about Samoan women's wartime history instead it is whispered in quiet conversations which carry a host of interpretations and attitudes towards women and war. This 'performance' suggests the whisperers' agenda and the possibility of other versions. These whispers have come to define the experiences of the wartime generation of Samoan women.

'O Keige Samoa ma a lakou kamai maligi' was the history of Samoan women and war that I have inherited. The disquieting performance and the obscurity surrounding Samoan women's wartime experiences lives not only in conversations, but also in the written narratives. I refuse to accept this legacy and question why only one specific aspect of Samoan women's lives is emphasised in Samoan memories. There is a range of women's experiences during the war that are of equal importance and are yet to be explored. I therefore call for a reconsideration of the history I have received. That call is the genesis of my research.

The central question of this study is: what were the experiences of Samoan women during World War II? At the heart of this question lies the desire to map out the extent to which women's wartime experiences impacted on their lives and their roles within their families and villages. Individuals have internalised their wartime experiences and have therefore negotiated and reordered their lives in the face of the profound moments of rupture brought by the war. Therefore, the question about women's wartime experiences is an inquiry into social transformation. The Second World War

\footnotetext{
${ }^{1}$ Faanunumi Rosa Tupai-Taeao, interview by Louise Mataia-Milo, Wednesday, 7 October 2014, Nu'usuatia, Upolu.
} 
stimulated social transformation in all combatant societies. In Samoa the arrival of the war challenged the accepted gender order causing a transformation of the lives of Samoan women and men. Exploring Samoan women's wartime experiences illuminates the degree to which the war was or was not a turning point in their lives.

Using oral history, the objective of this thesis is to construct a social history of Samoan women's wartime lives and to consider how women made sense of their experiences during the war years. Their experiences can tell us about Samoan society's understanding of the war and how individuals negotiated their lives. Adding Samoan women's voices widens our understanding of Samoan women's history. Their insights reveal different wartime experiences and layers of meanings, such as stories of gender and the power of women's agency to provoke social change in Samoan society. The place of women's lives in Samoan wartime history has been obscured by the academic tradition of overcommitting to political experience. This thesis shows that Samoan women and war history is an area worthy of study.

My encounter with the performances that surround the telling of Samoan women's wartime lives raised two further questions that also underpin this research. The first question is how much do we know about the generations of women who lived through the war? The second question concerns my role as a historian and storyteller who has refused to accept the history that was passed down to me. Joan Scott, informed by the thoughts of Walter Benjamin, emphasised the critical importance of the historian as 'part of a chain of storytellers, an intermediary, perhaps a midwife, who understands that she is bringing forth something that did not originate with her. ${ }^{2}$ We are charged with a responsibility to the next generation of storytellers to extend the knowledge that did not originate from us by asking questions of our recent past. I am aware as well of my role a historian within Samoan society and as a scholar within western academic traditions and conventions.

${ }^{2}$ Joan W. Scott, "Storytelling," History and Theory 50, no. 2 (May 2011), 204. 


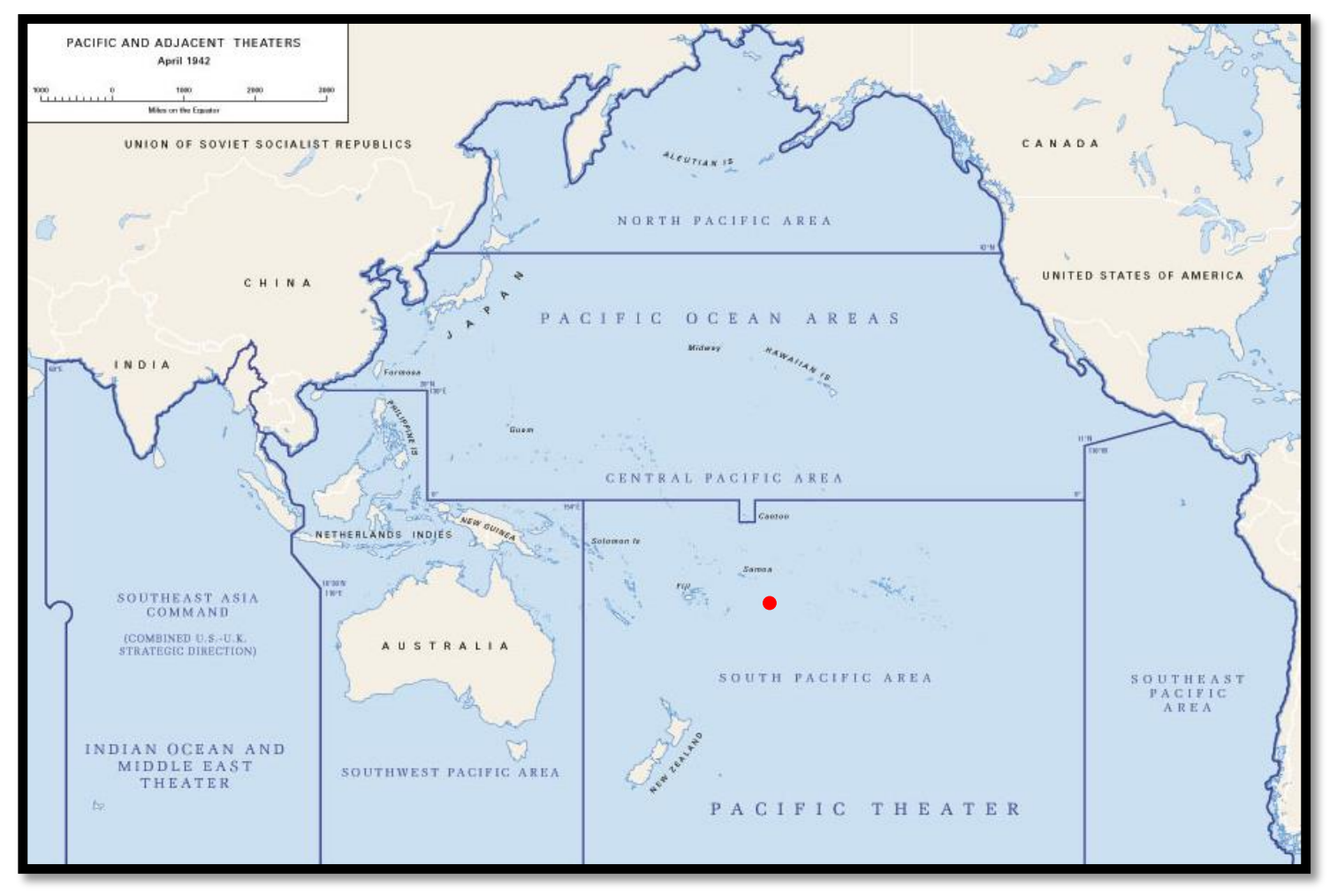

Figure 1 The Pacific and adjacent theatre. Samoa highlighted by a red dot. (Source: US Army Center of Military History).

\section{A historiographical discussion}

The Pacific, as shown in Figure 1, was a major theatre of the Second World War between the Allies and Japan. The Japanese bombing of the United States Naval base at Pearl Harbour in December 1941 set in motion forces that brought many young men and armaments into Oceania, transforming the usually quiet region into an important and busy war zone. The Pacific Islands, home to indigenous Pacific islanders, became a theatre of war, the location of military bases and was inundated with either Japanese or American soldiers. The war brought over 15,000 young American marines to the Samoa islands and radically influenced the entire Samoan population of approximately over $60,000 .{ }^{3}$ The war was a major moment of change in the lives of Samoan women and men as well as in the Pacific Islands' relations with world powers.

\footnotetext{
${ }^{3}$ Robert Franco, "Samoans, World War II and Military Work," in Remembering the Pacific War, ed. Geoffrey M. White (Honolulu: Center for Pacific Islands Studies, School of Hawaiian, Asian and Pacific Studies, 1991). 176. Western Samoa's population stood at 57,759 in 1938. American Samoa's population in 1940 was about 12,908 in total, in which about 10,000 were indigenous civilians. See: "Eighteenth Report of
} 
Writing about the history of the war and the experiences of Samoan and other Pacific islanders is uneven. As we shall see in this introductory discussion much of the writing has been shaped by particular geographical, political and economic concerns which often have overlooked, side lined or marginalised the experiences of Pacific islanders, including Samoans and especially women.

\section{The Pacific war historiography}

Much of the historiography of the Pacific war has been dominated by military histories which have focussed attention on the Western and Northern Pacific and in turn on the Oceanian culture areas of Melanesia and Micronesia. This in part reflects the focus on the fighting and the principal campaigns. The Battle of the Coral Sea in May 1942 was the first time the Allies stopped the Japanese Imperial Navy, preventing the Japanese forces from landing in Papua. The Battle of Midway Island in June 1942 ended any Japanese designs for control of the Pacific theatre and was immediately followed by the Battle of Guadalcanal, a military offensive from August 1942 to February 1943 that eventually overwhelmed Japanese forces in the Solomon Islands. The campaign then continued through Micronesia. ${ }^{4}$ As one moves away from the battle lines towards island groups such as Tonga and Samoa, which were forwarding bases for the US forces, the literature thins out.

The attention paid to certain areas also reflects the "national" preoccupations of Australian and US historians who have followed their nation's troops. Australian historical research, for example, has focussed on the Kokoda Track campaign in Papua New Guinea. Kokoda has become part of Australia's celebrated war for freedom that

the Government of New Zealand on the Administration of the Mandate territory of American Samoa for the Year Ended 31 st March, 1938." In Appendices to the House of Representative (AJHR). 2; Joseph Kennedy, The Tropical Frontier: America's South Sea Colony (Mangilao: Micronesian Area Research Center, University of Guam, 2009). 198.

${ }^{3}$ James F. Dunnigan and Albert A. Nofi, The Pacific W ar Encyclopedia ed. Albert A. Nofi (New York: Facts On File, 1998). 
seldom features the Melanesian villagers. ${ }^{5}$ The domination of the Pacific war historiography by American historians reflects a similar commitment from US historians. The New Zealand historians have also followed suit through the work of John Crawford, Ian McGibbon and many others. ${ }^{6}$

Writing about Pacific islanders was often overlooked in the earlier military histories. The dominant colonial and military view relegated islanders' wartime experiences to looting, involvement in cargo cults and millenarian movements. The war historiography, according to Hugh Laracy, portrayed Pacific islanders as observers rather than participants, as looters with insignificant roles in the war. ${ }^{7}$ In 1994 Laracy noted that 'published accounts of Pacific islanders' involvement in the war are very few and less abundantly informed' than the military histories. He was also concerned about the growing 'fragility' of oral sources as the generation who experienced the war began to take their experiences with them to the grave. ${ }^{8}$

Over time, however, and especially since the late 1980s, more and more attention has been paid to the experiences of Pacific islanders as labourers, combatants and witnesses to the war. The collections of oral histories edited by Geoffrey White and Lamont Lindstrom between 1987 and 1991 did much to redress the absence of Pacific islanders and their voices and to stimulate new research. The books Pacific Encounters, The Pacific Theatre and Remembering the Pacific $W$ ar, brought to the fore Pacific islanders' perspectives and understandings about what the war meant for them. ${ }^{9}$ These histories presented how the lives of Pacific people were disrupted as their homes became battlegrounds. The

\footnotetext{
5 P. Macinnis, Kokoda Track: 101 Days (Fitzroy: Black Dog Books, 2007); Peter Provis, "'Track' or 'Trail'? The Kokoda Debate 1," Flinders Journal of History and Politics 26 (2010); Gwen Bessell-Browne, The Road to Kokoda and Other Verses (Melbourne: Robertson and Mullins, 1943).

${ }^{6}$ John Crawford, New Zealand's Pacific Frontline: Guadalcanal-Solomon Islands Campaign, 1942-45 (Wellington: New Zealand Defence Force, 1992).

${ }^{7}$ Hugh Laracy, "George Bogese: Just a Bloody Traitor?," in Remembering the Pacific War, ed. Geoffrey M. White (Honolulu Center for Pacific Islands Studies, School of Hawaiian, Asian \& Pacific Studies, University of Hawai i at Manoa, 1991), 149-69.

${ }^{8}$ Hugh Laracy, "World War Two," in Tides of History: The Pacific Islands in the Twentieth Century, ed. K.R. Howe; Robert C. Kiste and Brij V. Lal (St Leonards: Allen \& Unwin, 1994), 153-4.

${ }^{9}$ Geoffrey M. White, ed. Remembering the Pacific War (Honolulu: Center for Pacific Islands Studies, School of Hawaiian, Asian and Pacific Studies, 1991); Geoffrey M. White and Lamont Lindstrom ed., The Pacific Theater: Island Representations of World War II (Honolulu: University of Hawaii Press, 1989); Geoffrey M. White ed, Pacific Encounters: Island Memories of World W ar II (Honolulu: East-West Center, 1987).
} 
war, usually seen as a cruel environment, appeared as a stage on which islanders' futures were irreversibly transformed.

Further oral histories of Micronesian experiences have revealed the complexities of militarisation endured by Pacific islander populations. The integration of oral histories has enhanced historical analysis by providing another means to discuss indigenous wartime agency. Oral history enables protagonists or actors in history to tell their stories. Their accounts may or may not be complete, 'true' or consistent, but oral history allows their voices to be heard in their history. Anthropological analyses by Falgout, Poyer and Carucci of Micronesians' memories of the Japanese and American occupation during the war are excellent examples of this kind of history. ${ }^{10}$ Their access to over 300 oral histories of Micronesian men and women permit us to sense the tragedy of the war in the North-Western Pacific. They show how the Pacific war caused a generation gap for the people of Micronesia; a generation was forced to accept Japanese ideals and abandon their own indigenous ways, which created a gap in Micronesian indigenous knowledge. ${ }^{11}$

Recent work by Geoffrey White and Eveline Buchheim signals another arc of war memories where new generations, in the absence of 'embodied voices of experience, draw from war histories as reference points to map out how their wartime relatives moved through spaces of remembrance to invent new nodes of wartime memories for themselves. ${ }^{12}$ White and Buchheim show the importance of war histories as resources that future generations will call on for the answers they seek from the past. Understanding the importance of providing the next generation with a more substantiated map of past wartime lives, has intensified my commitment to women and war history as an area worthy of study

Although the focus of these histories was mostly still on Melanesia and Micronesia, since the 1990s more attention has been paid to the experiences of islanders in the South Pacific area, including New Caledonia, Fiji, Tonga, American and Western Samoa

${ }^{10}$ Lin Poyer, Suzanne Falgout and Laurence M. Carucci, The Typhoon of War: Micronesian Experiences of the Pacific War (Honolulu: University of Hawaii, 2001).; Suzanne Falgout, Lin Poyer and Laurence M. Carucci, Memories of war: Micronesians in the Pacific War (Honolulu: University of Hawaii, 2008).

${ }^{11}$ Falgout et. al., The Typhoon of War, 326-9.

12 Geoffrey M. White and Eveline Buchheim, "Travelling War: Memory Practices in Motion," History and Memory 27, no. 2 (2015), 11. 
and the Cook Islands. For example, Robert Franco's contribution to Remembering the Pacific War examined the military work carried out by American Samoans (a topic discussed in more detail below). ${ }^{13}$ In 1998 historians of Tonga turned their attention to Tongan experiences. Like its neighbour Samoa, Tonga was a base behind the lines. The contributors to Echoes of Pacific War paid particular attention to the Tongan people's experiences. ${ }^{14}$ These scholars explored aspects of social change such as value systems, the arts, migration, family planning and the emergence of a new middle class. These aspects of Tongan life were all affected by the war. More recently, Kim Munholland has examined the political, economic and cultural challenges that the American presence in New Caledonia presented to French authorities. ${ }^{15}$

Fijian historians also have paid attention to wartime experiences. ${ }^{16}$ Brij Lal has asked how the Fijian ethnic groups perceived the war noting the local political and social fractures between the itankei-indigenous Fijians and the Indians. According to Lal, the itaukei response, loyalty to the Crown, was a politically calculated manoeuvre by the chiefs to keep them in favour with the British colonial government. In contrast to the itankei's engaged reaction to the war, the Indians were reluctant because of unresolved grievances, mostly to do with wages and their status as indentured labourers. ${ }^{17}$

Lal's research reveals that people's understanding of their wartime experiences are embedded in the pasts they know. They bring these motivations to the fore as they negotiate their wartime responses. For the Indian population, their colonial experiences as indentured labourers, servants, the continuous rejection of appeals to the government for equal treatment and equal pay, and the government's colluding with the Colonial Sugar Refinery against them, provided the basis of their attitude towards the war. Lal also showed how some Europeans began to distance their loyalty from the

13 Franco, "Samoans, World War II, and Military Work."

14 Deryck Scarr, Niel Gunson, and Jennifer Terrell, eds., Echoes of Pacific War: Papers from the 7th Tongan History Conference Held in Canberra in January 1997 (Canberra: Target Oceania, 1998).

${ }_{15}$ Kim Munholland, Rock of Contention: Free French and Americans at War in New Caledonia, 1940-1945 (New York: Berghahn Books, 2005), 142-172.

16 Deryck Scarr, Ratu Sukuna: Soldier, Statesman, Man of Two Worlds (London: Macmillan 1980).; Asesela Ravuvu, Fijians at War, 1939-1945 (Suva: Institute of Pacific Studies, University of the South Pacific, 1988).

${ }^{17}$ Brij V. Lal, "For King and Country: A Talk on the Pacific War in Fiji," in Remembering the Pacific War, ed. Geoffrey M. White (Honolulu: 1991), 19-25. 
British Empire, only to encounter a different type of westerner, the Americans, who threatened the established order.

Perhaps the most elusive wartime experiences are those of Pacific islander women. This research seeks Samoan women's perspectives on how wartime social interactions at grass root levels contributed to social transformation. These experiences and perspectives, often seen as trivial and unimportant, are historically significant.

Pacific scholars' attention to questions about the nature and consequences of wartime 'fraternizing' in the Pacific only began in the 1990s, but popular understandings of this topic date from the time of the war. In 1947 James Michener introduced the world to wartime social relations between Pacific women and American GIs not as a history but as a series of short stories titled Tales of the South Pacific. ${ }^{18}$ These stories took on a life of their own, became a hit on Broadway and later turned into a Hollywood film. ${ }^{19}$ The information Michener collected in his role as the official naval historian for the Pacific region in 1945 informed his short stories. Michener addressed issues such as wartime inter-racial relationships with indigenous women by portraying a variety of wartime social relations in a variety of mythical Pacific locations. ${ }^{20}$

To have these fantasies inform the abstract history of Samoan women's wartime lives that I have inherited is certainly a cause for concern. Michener's work was not historical and his views, as manifested in Tales of the South Pacific, do not capture the wartime realities lived by many Pacific women and they misinterpret and distort the meanings of their experiences. What the Tales do confirm though is that young men's perceptions of the Pacific were fuelled by Hollywood images and the idea that the Pacific Islands were an arcadia of sexual fantasies. His Tales seem to render people's realities meaningless. This study seeks an explanation for such histories from those who lived these wartime realities so as to fully understand and appreciate the past on its own merits.

This aspect of the study is informed by research elsewhere in the Pacific. Beth Bailey and David Farber examining wartime Hawai'i illuminate how the war, even within the

\footnotetext{
${ }^{18}$ James Michener, Tales of the South Pacific (New York: Macmillan, 1947).

19 James A. Michener, The World Is My Home: A Memoir (New York: Curtis Publishing Company, 1992).

20 Judith A. Bennett and Angela Wanhalla, "Introduction: A New Net Goes Fishing" in Judith A. Bennett and Angela Wanhalla eds., Mothers' Darlings of the South Pacific: The Children of Indigenous Women and U.S. Servicemen, World War II (Honolulu: University of Hawai'i Press, 2016), 9.
} 
American territory, made life more treacherous for women. ${ }^{21}$ Many Hawai'ian women became victims of racial and sexual discrimination by the soldiers. Prostitution and STDs were on the rise in Hawai'i at the beginning of the 1940s as many young American men were brought to island.

Scholars with Tongan interests have been at the forefront of efforts to document Tongan women's experiences and social changes from the war. For example, Sosiua Lafitani's has discussed the 'multiplicity of contradictions' in values and behaviour as Tonga became modernised by the war. ${ }^{22}$ Elizabeth Wood-Ellem highlighted the experiences of women like Tupou Posesi Fanua who was ostracised for living with a US naval officer. Wood-Ellem also introduced Saiatua Lavulo, who was appointed by Queen Salote as the first Tongan policewoman to assist the US Medical officials to treat the imprisoned Tongan women infected with venereal disease. ${ }^{23}$ Saiatua's story illustrates Salote's efforts to culturally mediate the treatment process. Charles Weeks' evaluation of the American occupation of Tonga, which focused on wartime politics and the economic boom, also touched on venereal disease and prostitution focusing on the armed forces strategies to keep the incidence of infection low by imprisoning women of 'loose character' to administer treatment. ${ }^{24}$ Imprisonment had been the classic treatment for women by the military since the seventeenth century. ${ }^{25}$

Wood-Ellem's biography of the Tongan monarch, Queen Salote, highlights the multitude of anxieties that heightened women's wartime experiences. Queen Salote's position as the head of state and her role as a mother meant she was charged with the many responsibilities of organising a whole country during the war. By royal decree,

${ }^{21}$ Beth L. Bailey and David Farber, The First Strange Place: Race and Sex in World War II Hawaii (Baltimore: Johns Hopkins University Press, 1994).

22 Siosiua F Pouvalu Lafitani, "New Behaviours and Migration since World War II," in Echoes of Pacific

War, ed. Niel Gunson Deryck Scarr, Jennifer Terrell (Canberra: Target Oceania, 1998) , 76-82

${ }^{23}$ Elizabeth Wood-Ellem, "Behind the Battle Lines: Tonga in World War II in Echoes of Pacific War, ed. Niel Gunson Deryck Scarr, Jennifer Terrell (Canberra: Target Oceania, 1998), 16

${ }^{24}$ Charles J. Weeks, "The United States Occupation of Tonga, 1942-1945: The Social and Economic Impact," Pacific Historical Review 56, no. 3 (August, 1987), 417-18.

${ }^{25}$ Kimeya Baker, "The Contagious Diseases Acts and the Prostitute: How Disease and the Law Controlled the Female Body," Journal of Law and Jurisprudence 1, no. 1 (2012), 93-5. 
Queen Salote declared all war babies as Tongans and saved them from societal wrath. ${ }^{26}$ The Samoans, who were under colonial rule at the time, did not have such luck.

In the Cook Islands Charlotte Macdonald has explored another facet of colonial connections between the Pacific islanders and New Zealand, which led to many Cook islander women being employed in New Zealand as domestic servants during and after the Second World War. ${ }^{27}$ She examines the hardships these young island women went through because of the choices they made and the colonial connections that altered their lives. Rosemary Anderson has documented the Cook Island women's experiences as domestic workers in New Zealand homes. ${ }^{28}$

The recently published Mothers' Darlings of the South Pacific has highlighted the consequences of intimate relationships between Pacific indigenous women and American marines. ${ }^{29}$ The authors have focused on the lives of the children of these unions and how nature of their parents' wartime relationships shaped their lives. My research in this project reveals how such relationships brought shame to the families and challenged the moral values of the Samoan society. ${ }^{30}$ This thesis expands the discussion started by Bennett and Wanhalla, looking at other aspects together with sexual encounters. Researching about Samoan women's wartime experiences is a platform to learn more about the silences, shame and stigmatism. It is through knowing and understanding these dynamics that appreciation and healing may come.

The racial dimension of wartime relationships also cannot be ignored. Racial attitudes disadvantaged Pacific islanders, but are infrequently acknowledged in the Pacific war histories. Prejudices exist in every society and are carried by people across cultures into different cultural environments. The Japanese forces and the Allied soldiers often used demeaning words from their homelands to refer to Pacific islanders in a derogatory

\footnotetext{
${ }^{26}$ Elizabeth Wood-Ellem, Queen Salote of Tonga: The Story of An Era, 1900-1965 (Auckland: Auckland University Press, 1999); Bennett and Wanhalla, ed. Mothers' Darlings of the South Pacific, 182.

27 Charlotte Macdonald, "Taking Colonialism Home: Cook Island "Housegirls" in New Zealand, 19391948," in Colonization and Domestic Service : Historical and Contemporary Perspectives ed. Victoria K. Haskins and Claire Lowrie (New York: Routledge, Taylor \& Francis Group, 2015).

28 Rosemary E Anderson, "The Origins of Cook island Migration to New Zealand, 1920-1950" (MA thesis, University of Otago, 2015).

${ }^{29}$ Bennett and Wanhalla, ed. Mothers' Darlings of the South Pacific: The Children of Indigenous Women and U.S. Servicemen, World War II (Honolulu: University of Hawaii, 2016).

${ }^{30}$ Saui'a Louise Mataia-Milo, "There Are No Commoners in Samoa" in Bennett and Wanhalla, ed. Mothers' Darlings of the South Pacific, 42-82
} 
way. ${ }^{31}$ Racial discrimination was embedded in US military institutions. It was manifested in the segregated camps and units for African American soldiers in the Pacific area of command. No African American units were stationed in Samoa. ${ }^{32}$

Bennett, citing MacGregor's discussion of racial segregation in the US Armed forces, indicates how racial ideologies were well entrenched in military officials' principles and practices. Major General Charles Price, commander of the Marine Corps of the Samoa Defence Group, took upon himself the moral obligation to protect the 'primitively romantic' Samoan women from intimate relations with the African Americans. Price believed that the Polynesian "mixture with the white race produced 'a very high-class half-caste.' Mixture with the Chinese would result in, 'a very desirable type"'. However, as Bennett and Macgregor noted, Price believed that a Samoan's union with an African American or Melanesian would produce "a very undesirable citizen." 33 Price’s opinion suggest that 'race' or 'dark colour of the skin' was an aspect. The two African American units that arrived in American Samoa on 13 October 1943, were immediately sent to the Ellice Islands the next day. ${ }^{34}$ This racial preoccupation was important because it meant that the Samoan women did not have any sexual relations with the African American soldiers. This was different to the situation in Tonga. ${ }^{35}$

In relation to the wider scholarship on the Pacific war this thesis seeks to further extend the attention paid to the experiences of Pacific islanders as civilians who were behind the lines but whose islands were nevertheless "occupied" for the duration of the war. Using oral history to focus on the wartime experiences of Samoan women in particular will introduce their experiences into the wider scholarship on women and war. The oral histories show how Samoan women, as Pacific islanders, responded to the US forces.

\footnotetext{
${ }^{31}$ Judith Bennett, Natives and Exotics: World W ar II and Environment in the Southern Pacific (Honolulu: University of Hawaii Press, 2009), 29.

32 Bennett, Natives and Exotics, 33.

33 Price cited in Morris J Macgregor, Integration of the Armed Forces, 1940-1965 (Washington: Centre of Military History, 1981), 110-111; cf. Bennett, Natives and Exotics, 33.

34 Bennett, Natives and Exotics, 33 citing Morris J Macgregor, Integration of the Armed Forces, 1940-1965. (Washington, Centre of Military History, 1981), 110-111, citing Price.

35 Charles J. Weeks, "The United States Occupation of Tonga, 1942-1945: The Social and Economic Impact," Pacific Historical Review 56, no. 3 (August, 1987), 417-18; Deryck Scarr, Niel Gunson and Jennifer Terrell, ed., Echoes of Pacific War (Canberra: Target Oceania, 1998).
} 


\section{Gender as a category of analysis in war history}

In examining the wartime experiences of Samoan women this thesis draws on wider writing about women in wartime using gender as a category of analysis. The historiography on women's wartime experiences during World War II is well established in the Americas, Europe, Australia and New Zealand. Pacific women's wartime experiences have just begun. Nicholas Thomas in the early 1990s challenged Pacific historians to use gender as a category of analysis to explore Pacific history. Thomas argued that 'gender should not be taken as a marginal topic which can fruitfully be added to a more general history, as a way of rectifying an omission. Instead, the question of gender transforms the way one understands colonialism and the kinds of representations and encounters it has entailed. ${ }^{36}$ It is the intention of this study to explore Samoan gendered wartime experiences to further understand the extent of Samoan women's agency in a tumultuous time.

The women's liberation movement of the 1970s onwards stimulated interest in women's history, expanding the field of historical inquiry. ${ }^{37}$ Joan Scott postulated the use of gender as a category for historical analysis. For Scott this approach 'will yield a history that will provide new perspectives on old questions redefine the old questions in new terms, making women visible as active participants, and create analytic distance between the seemingly fixed language of the past and our own terminology. ${ }^{38}$ She stressed the importance of language dynamics that imply cultural representations that construct gendered experiences. ${ }^{39}$ Scott's re-evaluation of the questions and methods of history in the 1980s widened the scope of historical scholarship.

Gender historians challenged the traditional nature of mainstream historical practice which seemed to have locked women's experiences out of written histories. For example, the debate in the 1980s about what the war did or did not do for women caused feminist historians to call for a reassessment of historical approaches. Feminist

\footnotetext{
${ }^{36}$ Nicholas Thomas, "Partial Texts: Representation, Colonialism and Agency in Pacific History," The Journal of Pacific History 25, no. 2 (December 1990), 150.

${ }^{37}$ Betty Friedan, The Feminine Mystique (Harmondsworth: Penguin, 1965); Gerda Lerner, Why History Matters: Life and Thoughts (New York: Oxford University Press, 1997); Joan Kelly, Women, History and Theory: The Essays of Joan Kelly (Chicago: University of Chicago Press, 1984), 198.

38 Joan W. Scott, "Gender: A Useful Category of Historical Analysis," The American Historical Review 91, no. 5 (1986), 1075.

${ }^{39}$ Joan W. Scott, Gender and the Politics of History (New York: Columbia University Press, 1999), 50.
} 
historians redefined the concepts of politics and power as well as the language applied by historians to document history. The private lives of ordinary people, notably women, became part of History. ${ }^{40}$

These approaches have enabled women's wartime experiences to be developed as an area worthy of study. The war as a category of analysis and gender are important and have informed the questions about 'women and war' in the work of feminist historians such as Penny Summerfield, Christine Sylvester, Marilyn Lake, Joy Damousi and Cynthia Enloe. ${ }^{41}$ Summerfield was one of the first historians to embrace Scott's approach in her discussion of British women's wartime labour and social experiences. ${ }^{42}$ She influenced Sylvester's call to conceptualise war as a subset of social relations and wartime experiences, because war cannot be fully understood unless it is studied from the people who experience it in myriad ways. ${ }^{43}$ Persis Charles has argued that the war is a 'powerful prism through which to view the history of women and that the history of women can act with the same power to view the history of war. ${ }^{44}$ The thesis is a Samoan response to feminist historians' call.

Penny Summerfield's theoretical perspectives also contribute to our understanding of how women reorganised their lives to ensure that the home front was secure and that their families did not suffer in the absence of the men folk. ${ }^{45}$ War did not affect just the men who went to fight, especially in World War II. Women were also at the heart of the war, at the home front, at the frontline as nurses and far behind the battle lines at forwarding bases such as Samoa. Indigenous women's lives were also affected in areas

40 Gerda Lerner, Why History Matters: Life and Thoughts (New York: Oxford University Press, 1997); Joan Kelly, Women, History and Theory: The Essays of Joan Kelly (Chicago: University fo Chicago Press, 1984), 198. ${ }^{41}$ Christine Sylvester, Feminist Theory and International Relations in Postmodern Era (Cambridge: Cambridge University Press, 1994); Penny Summerfield, Reconstructing Women's Wartime Lives (Manchester: Manchester Univesity Press, 1998); Cynthia Enloe, Seriously! Investigating Crashes and Crises as if Women Mattered (California: University of California Press, 2013); Joy Damousi and Marilyn Lake, ed. Gender and War: Australians at War in the Twentieth Century (Melbourne: Cambridge University Press, 1995).

42 Summerfield, Reconstructing Women's Wartime Lives; Penny Summerfield, "Culture and Composure: Creating Narratives of the Gendered Self in Oral History Interviews," Culture and Social History 1 (2004), 65-93.

${ }^{43}$ Christine Sylvester, $W$ ar as Experience: Contributions from International Relations and Feminist Analysis (Canada: Routledge, 2012), 15.

44 Persis Charles, "Women and the Two World Wars: Report on Conference at Harvard," Women's Studies Quarterly 12, no. 2 (Summer, 1984), 7.

45 Summerfield, Reconstructing Women's Wartime Lives. 
where military forces were stationed. Samoan women, like American, European and African women, reorganised their lives during the war.

Australasian feminist historians also have brought forward a range of issues that were important in their own respective communities. Topics such as 'feminine desire', identity and indigenous vulnerability during the war highlight how wartime experiences are intertwined with local. Marilyn Lake and Kate Darian-Smith in their separate discussions highlight the concerns about women of Melbourne communities and their engagement with wartime popular culture. ${ }^{46}$ Fiona Paisley's consideration of Aboriginal women's lives emphasises the different cultural dynamics that influenced Australian women's wartime lives. ${ }^{47}$ Lauris Edmond, Deborah Montgomery and Pamela Hyde have brought to the historiography New Zealand women's voices about their experiences during the two world wars showing the diversity of personal experiences and the wars' effects on families. ${ }^{48}$ Pamela Hyde, informed by Foucault's notion of power operating in the micro-political levels of society, explores how the print media, namely the New Zealand Woman's Weekly, constructed suitable bodies and behaviours to reflect women's vital roles in the war effort. ${ }^{49}$ This study brings Samoan wartime narratives to the scholarship on women and war.

Many contemporary indigenous people and war histories have applied post-colonial notions in their reassessment of past experiences. ${ }^{50}$ The significance of this growth in the literature from non-western societies is that it decentres but complements western gender historiography by bringing to the fore indigenous women's wartime experiences. Natalie Zemon Davis has argued that, 'The de-centring historian does not tell the story

\footnotetext{
${ }^{46}$ Marilyn Lake, "Female Desires: The Meaning of World War II," in Gender and War: Australians at War in the Twentieth Century, ed. Joy Damousi and Marilyn Lake (Cambridge: University of Cambridge, 1995), 6080.; Kate Darian-Smith, On the Home Front: Melbourne in Wartime 1939-1945 (Melbourne: Oxford University Press, 1991).

${ }^{47}$ Fiona Paisley, "No Back Streets in the Bush: 1920s and the 1930s Pro-Aboriginal White Women's Activism and the Trans-Australia Railway," Australian Feminist Studies 12, no. 25 (1997), 119-137.

${ }^{48}$ Lauris Edmond, ed. Women in Wartime: New Zealand Women Tell Their Story (Wellington: Government Printing Office, 1986); Deborah Montgomery, "Reassessing Rosie: World War II, New Zealand Women and the Iconography of Femininity," Gender and History 8, no. 1 (April, 1996), 108-132.

49 Pamela Hyde, "Managing Bodies - Managing Relationships: The Popular Media and the Social Construction of Women's Bodies and Social Roles from the 1930s to the 1950s," Journal of Sociology 36, no. 2 (2000), 157-71.

${ }^{50}$ Harauko Taya Cook, "Memories of Japan's Lost War," Journal of American-East Asian Relations 11, no. 1/4 (2002), 25-40; Jeanne Vickers, Women and War (London: Zed Books, 1993); Nancy L. Clark, "Gendering Production in Wartime South Africa," American Historical Review 106, no. 4 (October, 2001), $1181-1213$.
} 
of the past only from the vantage point of a single part of the world or of powerful elites, but rather widens his or her scope, socially and geographically, and introduces plural voices into the account. ${ }^{51}$ The war was a global phenomenon that mobilised many people of different cultures and races to parts of the world they were not familiar with. Local experiences were also global shared experiences. My thesis about Samoan women's experiences is also situated within this scholarship.

The feminist lenses enable me to analyse the four selected aspects of Samoan women's wartime lives that this thesis explores, namely: their roles in the family and the village, their relationships with the church, their engagement with popular culture and lastly their wartime sexual encounters. These experiences are at the core of this thesis. The intention is to examine Samoan women's wartime experiences by identifying the breaks that kept their narratives from entering Samoan history. Using Samoan gender as a category of historical investigation reveals an array of processes that shaped Samoan women's wartime experiences. Furthermore, these allow us to understand not only people's motivations but also the effects of people's actions.

${ }^{51}$ Natalie Zemon Davis, "Decentering History: Local Stories and Cultural Crossing in a Global World," History and Theory 50 (May, 2011), 190. 


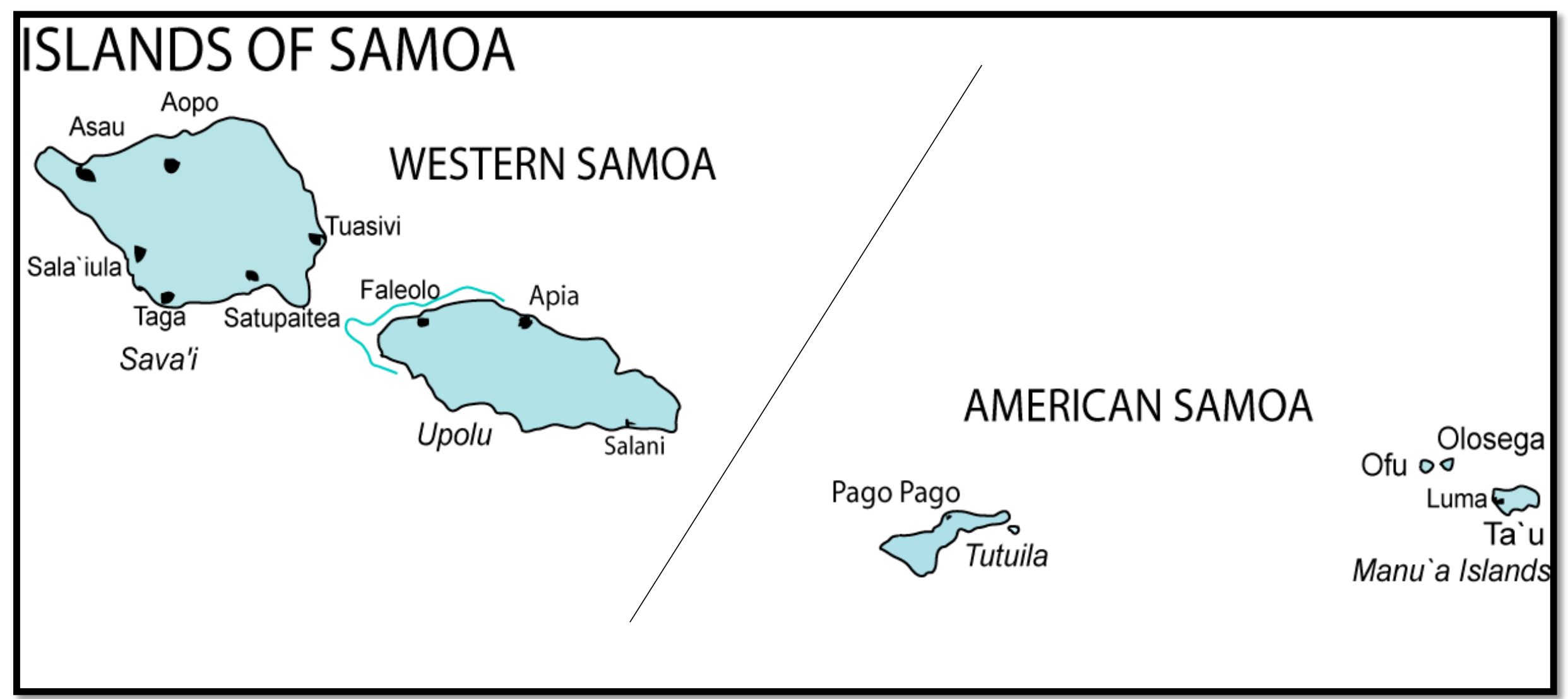

Figure 2 Map of the Samoa Islands 


\section{Samoan historiography and its intersection with the war}

Another major historiographical area that this thesis engages with is the history of Samoa itself. It is not surprising that little attention has been paid to the wartime history of Samoa (Western Samoa and American Samoa) in its own right. Most of Samoa's known history is about the contests for power and titular titles which led to civil wars. Samoa did not have the luxury of official war histories because it was not a sovereign country. The two Samoan territories, as shown in Figure 2, were not sovereign political entities and had no control over their wartime participation. When the war broke out, Samoa was a single society, but two colonial territories under the control of two separate administrations. The eastern islands, including Tutuila and Manu'a group, had been under American rule since 1899 while the western islands, including Upolu and Savai'i, had been under NZ administration as a League of Nations class C Mandate since 1920 (having been taken over from Germany in 1914). The Mandate rules, which disallowed the raising of any formal standing armed forces in Western Samoa, determined its participation in the conflict as well as how it would go into the history books. The two territories were in a war zone, but they were not combatant nations. For this reason, they appear in the United States and New Zealand war histories as colonial territories on the margins of the war. This study considers the two separate territories as a single cultural area, the Samoa islands.

In the 1950s, writing about Western Samoa's involvement in the Pacific war was shaped by the NZ official war histories. The 1952 volume on the Pacific campaign, written by Oliver A. Gillespie, only touches slightly on Western Samoa ${ }^{52}$ while F. L. W. Wood's 1958 volume focused on how the war moulded New Zealand's position in the international diplomatic arena and its foreign policies towards the Pacific. ${ }^{53}$ Wood highlights New Zealand's guiding role in administering the trusteeship and preparing Western Samoa for self-government. New Zealand's diplomatic ability in regional affairs made Western Samoa relevant to New Zealand's official war history. Neither history paid much attention to wartime developments in Samoa itself. The two authors

52 Oliver A. Gillespie, The Pacific, ed. Howard Karl Kippenberger, The Official History of New Zealand in the Second World War 1939-1945 (Wellington: Historical Publications Branch, 1952).

${ }^{53}$ F. L. W. Wood, The New Zealand People at War: Political and External Affairs, Official History of New Zealand in the Second World War 1939-45 (Wellington: War History Branch, Department of Internal Affairs, 1958), 327-347 
had different questions in relation to which the territory of Western Samoa was not a priority. The participation of Western Samoans in the NZ war effort also escaped notice; Joseph F. Cody devoted only half a sentence to the 'odd men from the Pacific' in his official history of the 28th Maori Battalion. ${ }^{54}$

Much of the writing about Samoan history that has emerged since the 1960s has been shaped by a preoccupation with resistance and political development in which the period of the war and its social history has not been seen as especially important. Western Samoa was the first Pacific nation to claim sovereignty from colonial rule in 1962. Documenting this milestone achievement of becoming a modern nation became the main focus. However, there were signs that historians were aware of what their preoccupation with the new political journey meant for Samoan historiography.

Davidson's consideration of the war in Samoa mo Samoa is very brief and general; the war presented a break from political action and a period of prosperity. However, as Davidson noted, the war also presented a challenge to the matai, the local chiefly authorities who had to implement village regulations and sought to restrict 'association between young women of the village and the troops'. ${ }^{55}$

Mary Boyd wrote that the war was 'a period of great disturbance and unaccustomed prosperity'. ${ }^{56}$ She posited in her various discussions that the war and the US occupation had 'served as the catalysts of resurgent nationalism'. ${ }^{57}$ Samoan leaders voiced their loss of confidence in the trusteeship of New Zealand during the war. Boyd asserted that the war's main effect on Samoan politics was 'to prolong the uneasy truce between New Zealand and Samoa, until once again the forces of Samoan nationalism threatened a major political eruption, ${ }^{58}$ She further noted the effect of the US presence on the village

\footnotetext{
${ }^{54}$ Joseph F Cody, (28) Maori Battalion, ed. Howard Karl Kippenberger, The Official History of New Zealand in the Second World War 1939-1945 (Wellington: Historical Publications Branch, 1956), 7. On Pacific Islander participation in the 28th Maori Battalion see: Louise Mataia, "Odd Men from the Pacific: The Participation of Pacific Island Men in the 28 (Maori) Battalion in the Second World War" (MA Thesis, Otago University, 2007); Kolokesa Mahina-Tuai, "Fia (Forgotten in Action) Pacific Islanders in the New Zealand Armed Forces," in Tangata O Le Moana, ed. Kolokesa Mahina-Tuai, Damon Salesa and Sean Mallon (Wellington: Te Papa Press, 2012).

${ }_{55}^{5}$ J.W. Davidson, Samoa Mo Samoa: The Emergence of the Independent State of Western Samoa (New York: Oxford University Press, 1967), 157-8

56 Mary Boyd, "The Record in Western Samoa to 1945," in New Zealand's Record in the Pacific Islands in the Twentieth Century, ed. Angus Ross (London: C. Hurst \& Co., 1969), 185.

${ }_{57}$ Mary Boyd, "The Decolonisation of Western Samoa," in The Feel of Truth: Essays in Zealand and Pacific History Presented to F.L.W Wood and J.C. Beaglehole on the Occasion of their Retirement, ed. Peter Munz (Wellington: A.H. \& A.W. Reed for the Victoria University of Wellington, 1969), 63.

58 Mary Boyd, "The Record in Western Samoa to 1945",184
} 
economy, 'the windfall of dollars and trade goods was mainly devoted to traditional Samoan purposes and there were few signs of permanent changes in the villages'. ${ }^{59}$ In Boyd's view, the war's political impacts slowly dismantled New Zealand's hold on the mandated colony.

Meleisea's abridged treatment of Samoans' wartime experiences in Lagaga does not do justice to Samoan women's wartime experiences. ${ }^{60}$ The political narrative which has been emphasised in the current historiography overlooks the importance of women's history and social history. Meleisea references the New Zealand Administration's Secretary of Native Affairs, G.G. A. McKay, who briefly reported on Samoans as labourers for the US forces, noting that this involvement had led to an increase in wealth; there also had been an increase in social activities and in the hosting of banquets by taupou women. This thesis provide a more detailed account of Samoan experiences, notably those of Samoan women.

The political implications of the war years also dominate American Samoa's limited historiography. The earlier political histories reflect its colonial status and illuminate the activities of the administration rather than the indigenous people. Captain J.A.C. Gray's history focused only on the time of the Naval Administration from 1900 to $1951 .^{61}$ Gray's discussion of the World War II period centred on the military manoeuvres, the mobilisation of military forces on the island and the growth of the economy. Gray mentioned that the war 'upset the balance of life, particularly in Tutuila' but does not give the view of the Tutuila people to justify such statements. ${ }^{62}$ The more recent publication, The Tropical Frontier: America's South Sea Colony, by Joseph Kennedy is another case in point. ${ }^{63}$ Kennedy integrated military and academic discussion with minimal Samoan contributions. He succeeded in casting new light on the United States' policies in American Samoa without considering the reactions of the Samoans.

\footnotetext{
59 Mary Boyd, "The Record in Western Samoa to 1945",185

${ }^{60}$ Malama Meleisea and Penelope Schoeffel Meleisea, eds., Lagaga : A Short History of Western Samoa (Suva: Institute of Pacific Studies, University of the South Pacific, 1987). 142, 154; Malama Meleisea, Change and Adaptations in Western Samoa, (Christchurch: M. Meleisea, 1992).

${ }^{61}$ J.A.C. Gray, Amerika Samoa: A History of American Samoa and Its United States Naval Administration (Annapolis, Md: United States Naval Institute, 1960).

62 Gray, Amerika Samoa, 240-45.

${ }^{63}$ Joseph Kennedy, The Tropical Frontier: America's South Sea Colony (Mangilao: Micronesian Area Research Center, University of Guam, 2009).
} 
Although the historiography has been focused more on political developments there are some references that show historians' awareness of wartime social change and economic developments. One of the most explored themes is the notion that the war provided an opportunity for Samoans to gain labour skills that became useful in the post-war era. In Samoa, as elsewhere in the Pacific theatre, local labour was critical to the Allies' war efforts, not only in the garrison construction leading up to the war, but also throughout the war period in the daily operations, servicing the troops' needs.

Pacific islander men became wage labourers, worked in construction and were taught carpentry and mechanical skills by the troops. Franco's survey of Samoa enquired into the connections between wartime economic wealth and social change in the post-war years. He highlighted the notion that the war accelerated the process of integration into a Western cash economy which eventually led to Samoans' migration to the metropoles in the post-war era. ${ }^{64}$ Franco argued that Samoans' wartime labour was a seedbed for emigration as well as a threat to traditional authority.

Franco's discussion of Samoans' wartime labour focussed mostly on male labour and overlooked women's wartime labour through nursing in both Samoan territories.

Moreover, Samoan women ran family owned restaurants to cater for the US marines and did washing for American dollars. ${ }^{65}$ The women who washed the marines' clothes and who did domestic work for naval families also earned cash. Davidson noted that wartime wealth and opportunities, such as Samoan women's laundry work, underpinned the drive for independence. He was also aware of the tense relationships between the indigenous authorities and the American GIs over their developing relationships with Samoan women. ${ }^{66}$ Cluny and La'avasa Macpherson have argued that these acquired skills altered the patterns of migration; individuals entered the labour market outside of Samoa with skills and became less dependent on family networks. ${ }^{67}$

Samoan historiography's political focus has not only hindered an in-depth analysis of wartime social transformation, but also suggested that social change followed on from

${ }^{64}$ Franco, "Samoans, World War II, and Military Work," 173.

65 R 93796 50, "Isabella Stowers Will," Archives New Zealand, Wellington (hereafter ANZ).

${ }^{66}$ Davidson, Samoa Mo Samoa, 157.

${ }^{67}$ Franco, "Samoans, World War II, and Military Work"; Cluny Macpherson and La'avasa Macpherson, The Warm Winds of Change (Auckland: Auckland University Press, 2009), 51-58. 
political transformation. Historians have concentrated their attention on the consequences of the wartime changes, rather than experiences during the war. Meleisea suggests that political development and independence led to the economic and social changes which modernised Samoa. ${ }^{68}$ Samoa's wartime history has been politically angled, with a focus on the political experiences of the economically active men whose labour was in demand during the war. That work experience incidentally led them to pick up skills that enhanced their employability outside of Samoa. Such analyses suggest a top-down linear flow of social change. Wartime politics gave the US Military command, the Navy and New Zealand administrations, the churches, the chiefs and the older people formal authority over the rest of the population. Change was expected to flow in the same direction. However, during the war, as this thesis will show, transformation did not follow the expected path.

One of this study's main arguments is that exploring the social aspects of Samoans' experiences during the war shows not only that social changes started from the "grass roots", but also that the changed wartime context neutralised the once stringent barriers and social structures, giving individuals the tools to control the rate of social change. By examining ordinary people's wartime experiences, this enquiry will widen the framework of Samoan social history.

\section{Gender as a category in Samoan histories}

Three Samoan scholars have addressed the changes in Samoan women roles using gender perspectives. Each of their studies is also relevant to this study in different ways. In 1979, Schoeffel presented case-studies that highlighted how gender and power relations within the Samoan family and in village women's groups influenced women's roles in families before and after marriage. ${ }^{69}$ Schoeffel found that church fellowship groups were less effective in their application of authority than the traditional gender groups such as the aualuma, faletua ma tausi, ma ava a taulelea. ${ }^{70}$ I will discuss these

\footnotetext{
${ }^{68}$ Malama Meleisea, The Making of Modern Samoa (Suva: Institute of Pacific Studies, 1987), 103.

${ }^{69}$ Penelope Schoeffel Meleisea, "Daughters of Sina: A Study of Gender, Status and Power in Western Samoa" (PhD Thesis, Australia National University, 1979); Penelope Schoeffel, "Rank, Gender and Politics in Ancient Samoa," The Journal of Pacific History 22, no. 4 (1987), 174-193.

${ }^{70}$ Samoan woman socialise through gendered institutions that reflect the social structure of Samoan society. All Samoan women identify with aualuma - a group of village young women, commonly referred to as the daughters of a village. This group is usually under the guardianship of an elderly 'daughter of the village who herself is either unmarried or a widow who has returned to her village of birth. When a
} 
groups in detail in Chapter Two. Schoeffel argued that the latter, the traditional gender groups, had more autonomy and power to effect changes in the family and village than the former. ${ }^{71}$ In her case study of Poutasi village she highlights the variations in the degree of social and religious influence on Samoan women's roles at different phases of their lives. This aspect of Schoeffel's observations is relevant to how I will explore women's roles as young women and as wives during the war period.

Fairbairn-Dunlop's oral history project published in the late 1990s explored Samoan women's lives from the 1950s to the 1990s and showed their commitment to their families and villages in the multiple roles they play within different social sectors of (Western) Samoa. Fairbairn-Dunlop's oral history evidence strongly supports the notion that women, in their traditional and modern roles, are driving forces of social change in Samoa. The subtle veneer of normality of this agency is the very reason this significant role has been overlooked by scholars. ${ }^{72}$

Jeannette Mageo's psychological approach to exploring gender and young women's behaviour is also a useful frame for this study. Mageo's idea that young women tend to conceal their true personal feelings to keep the order is a powerful way of thinking about young women during the war years. ${ }^{73}$ One of Mageo's principal ideas in Theorising Self is that cultural neglect is a form of control, 'the unsaid becomes the obsession of the system that neglects it. ${ }^{97}$ Women kept silent about their wartime experiences for many reasons. Many thought their lives were less important than the lives of others. Some were afraid in case they became stigmatised and others suffered in silence from the trauma of sexual violence. For many, historians simply never asked them to contribute to the narrative.

member of the aualuma marries, usually to a man outside of the village, the young woman then goes to live with her in-laws in that village. She then joins the group for wives of the village, Faletua ma tausi ma ava a taulelea - the group of wives Faletua (paramount chiefs' wives) and tausi (orator chiefs' wives) and ava a taulele'a (wives of untitled men).

71 Penelope Schoeffel Meleisea, "Women's Associations in the Rural Economy of the South Pacific: Case Studies from Western Samoa and East New Britain Provice, Papua New Guinea," (Noumea: South Pacific Commission, 1983).

72 Peggy Fairbairn-Dunlop, Tamaitai Samoa: Their Stories (USP Suva: KIN Publication, 1998), viii-ix, 1-15.

73 Jeannette Mageo, "Spirit Girls and Marines: Possession and Ethnopsychiatry as Historical Discourse in Samoa," American Anthropological Association 23, no. 1 (1996), 61-82; Jeannette Mageo, "Zones of Ambiguity and Identity Politics in Samoa," Jounal of the Royal Anthropological Institute, no. 14 (2008), 64-69. ${ }^{74}$ Jeanette Mageo, Theorizing Self in Samoa: Emotions, Genders and Sexualities (Ann Arbor: University of Michigan Press, 1998), 7-8. 
The use of gender as a category of analysis by Schoeffel, Fairbairn-Dunlop and Mageo has enabled them to address the subjectivities and the cultural symbolism that construct women's roles. Others have added to the consideration of Samoan women's lives. Asenati Liki has focused on Samoan women of Melanesian ancestry in the colonial period. Tina Tauasosi has examined Samoan women and domestic violence in the first decade of the twenty-first century. ${ }^{75}$ Simanu Klutz has studied women's power relations and women's political agency in her village, Saluafata, through the nineteenth and twentieth centuries, examining the forces that influenced the rise and fall of this agency. ${ }^{76}$

Schoeffel, Fairbairn-Dunlop and Mageo and the new generation of Samoan women scholars are important to this research. Although their questions, focus and time periods are different they provide important insights concerning the forces that have influenced Samoan women's lives over time. This study uses gender approaches to investigate how the war shaped women's power relations and in turn their roles and the process of social change. In addition, it will also address Samoan women as subjects rather than as objects of discussion. ${ }^{77}$ This will provide a more nuanced representation of Samoan women's wartime experiences. This thesis thus adds to the growing body of literature that explores Samoan women's lives and their agency through time.

\section{Towards a history of Samoan women's wartime experiences}

My study is organised around four broad aspects of Samoan women's lives during the Second World War: their roles in their families and communities; their relationships within the church; their engagement with wartime popular culture; and finally their wartime sexual encounters. All four aspects of women's wartime lives in this analysis will illuminate the dynamics that shaped wartime experiences and reveal the extent to which the war impacted on their agency.

\footnotetext{
75 Asenati Liki, "Rootedness in 'Aiga: Work and Movement among Teine Uli in Samoa and Aotearoa/ New Zealand" (PhD thesis, University of Hawai'i, 2007); Tina Tauasosi, "Sauaga O Tamaitai e a Latou Tane i Samoa: Wife Abuse in Samoa" (PhD thesis, University of Hawaii, 2010).

76 Manumaua Luafata Simanu-Klutz, "A Malu I Fale, E Malu Fo'i I Fafo' - Samoan Women and Power: Towards an Historiography of Change and Continuities in Power Relations in Le Nu'u O Teine of Saoluafata 1350 - 1998 C.E." (PhD thesis, University of Hawai'i, 2011).

${ }^{77}$ Nicholas Thomas, Entangled Objects: Exchange, Material Culture, and Colonialism in the Pacific (Harvard: The President and Fellows of Harvard College, 1991), 7-11.
} 


\section{Women's roles in their families and communities}

Exploring Samoan women's roles in the regulated wartime context shows how the war disrupted the old social order and normal routines of daily life. The discussion (developed mainly in chapter 3) examines the different ways that women exercised their agency to negotiate in ways suitable for their families the challenges presented by the wartime circumstances. Samoan culture prescribes Samoan women's roles and their place in Samoan society. Women are always considered a blessing to a family. Their prehistorical position as a link to ancient deities lends mana to their counsel. Women are the keepers of the covenant, the feagaiga, whose view is highly respected in decision making. In her daily family duties, the Samoan woman is the 'fai oa', the maker of tangible wealth, such as the highly valued fine mats, or ie toga. Fairbairn-Dunlop explores in Tamaitai Samoa the central role a Samoan woman has in Samoan society's social structure which in turn determines her place in society in the different phases of her life, as an unmarried woman and as a wife. ${ }^{78}$ The institutions of the taupou, the aualuma and the faletua ma tausi ma ava a taulelea are important gendered platforms. The agency of these institutions has undergone change over the years. The wartime period brought another wave of changes to women's roles and responsibilities. Samoan women had to negotiate and incorporate these changes into their lives. This study explores how the arrival of the war impacted on these roles and how the women in turn responded.

\section{Women's relations with the churches in wartime}

The church occupied a dominant role in all the Samoa islands by the mid-twentieth century, influencing every aspect of Samoan life. This area of the investigation (developed mainly in chapter 4) triangulates Samoan women, the church, and the Second World War. The advent of the war created social circumstances that challenged the ways in which the church marginalised women's traditional agency. As a social space, the church diffused the strangeness of the American marines while simultaneously providing spaces for social interactions that were difficult for the church authorities to control.

\footnotetext{
${ }^{78}$ Fairbairn-Dunlop, Tamaitai Samoa: Their Stories, 5.
} 
The mission schools were flagships that promoted Christian female roles in the late 1930s. However, the war created flexible social circumstances that sustained changes already started by the church that altered the trajectory of Samoan women's lives in the post-war era. The war coincided with the arrival of new missionaries, armed with new skills. Commercial practice, book keeping and secretarial skills such as typing and shorthand, were added to St. Mary's school curriculum during the war period. These signalled the anticipated changes in post-war employment which took Samoan women away from the domestic sphere. ${ }^{79}$

The numerous considerations of the church and women's agency highlight the missionaries as agents of social change. Others who have written about the churches in Samoa have focused on church policies but seldom devote any attention to women in the church during the war years. ${ }^{80}$ Missionaries' reflections indicate how the church began to change its procedures to coincide with cultural changes. ${ }^{81}$ Liua'ana in his assessment of war's impact on Samoa's ecclesiastical and political relationship presents evidence relating to the churches' involvement in coercing women into sexual encounters during the war. ${ }^{82}$ This study reveals the extent to which the church capitalised on wartime wealth and provided an important space for social interaction with the US servicemen.

\section{Women as consumers of popular culture}

As will be discussed in chapter 5 , the consumption of popular culture was a significant aspect of wartime experience. Popular cultural material in its many forms such as clothing, music, dances, candies, movies, reading material and cash, contributed to the rapid growth of the processes of social absorption and cultural transference between societies. The focus on Samoan women's engagement with wartime popular culture reveals several important features of their wartime experiences. Using wartime popular

\footnotetext{
${ }^{79}$ Emma Vaai, "Sister Patrick's Golden Girls," in Tamaitai Samoa: Their Stories, ed. Peggy Dunlop (Suva, Fiji: KIN Publication, 1998); Fairbairn-Dunlop, Tamaitai Samoa: Their Stories; Bernard Thorogood, ed. Gales of Change: Responding to a Shifting Missionary Context, The Story of the London Missionary Society 1945-1977 (London: World Council of Churches Publication, 1994), 79.

${ }^{80}$ Liua'ana, Samoa Tula'i: Ecclesiastical and Political Face of Samoa's Independence, 1900-1962.

${ }^{81}$ Hilda E.A. Small, Papauta: The Inland Rock (1967); Sister Mary Consolata, Samoa with Love: Reminiscences of Forty-Five Years (Waltham, Mass: Marist Missionary Sisters, 1991).

${ }^{82}$ Liua'ana, Samoa Tula'i, 277.
} 
culture as a historical frame shows that people's interactions do not fit in neatly with social expectations. These situations show that change does not always have a linear trajectory; events intermingled with existing understandings or circumstances to stimulate certain responses, creating new experiences. At the same time, this examination illustrates that people make history in the most ordinary ways. That is, mundane events are also important historical moments that effect social change.

Social scientists have noted that popular culture is easy to identify but rather difficult to define. ${ }^{83}$ Popular culture had many forms and served many functions during World War II not least as entertainment for soldiers. Longmate examined the impact of American servicemen on the British culture through their food, music, entertainment and romances ${ }^{84}$ Similar studies were conducted by Potts for Australia and Cleveland for New Zealand. ${ }^{85}$ Some historians use 'Pacific' in their titles, but reference only Australia and New Zealand and say nothing about Pacific islanders' engagement with wartime popular culture. ${ }^{86}$ This study addresses that absence.

There has been no analysis of Samoan women's engagement with wartime popular culture in the existing historiography. There has been, though, some treatment of the changes to diet that occurred. ${ }^{87}$ More generally, Bennett's Natives and Exotics shows how Americanism was filtered into the Pacific through objects and consumer goods which framed soldiers' views of Pacific islanders. ${ }^{88}$ Michener's exotic representation of Pacific Island women places him at the vanguard of the historiography of the Pacific war. Through his literary success, Michener repackaged the South Pacific, which became an item of popular culture consumed outside of the region from the post-war years to the

83 Tony Bennett, "Popular Culture: A Teaching Object," Screen Education 35 (1980), 18; Carla Freccero, Popular Culture: An Introduction (New York: New York University Press, 1992); Julie Reid, "Mythological Representation in Popular Culture Today," Communication Theory and Research 33, no. 2 (2008), 80-98. ${ }^{84}$ Norman Longmate, The G.I.'s (New York: Scribner's, 1975).

${ }^{85}$ E. Daniel Potts, Yanks Down under 1941-45 (Melbourne: Oxford, 1985); Les Cleveland, "When They Send the Last Yank Home," Journal of Popular Cultures 18 (1984), 31-36. See also Barbara Friedman, "The Soldier Speaks: Yank Coverage of Women and Wartime Work," American Journalism 22, no. 2 (2013), 6382.

${ }^{86}$ Loyd E. Lee, ed. World War II in Asia and the Pacific and the War's Aftermath, with General Themes (Westport, Conneticut: Greenwood Press, 1998); Ruth Elwell, "Popular Culture and World War II," in Popular Culture and World War II: World War II in Asia and the Pacific and the War's Aftermath, ed. Loyd E. Lee (Westport, CT.: Greenwood Press, 1998).

87 James R. Bindon, "Breadfruit, Banana, Beef, and Beer: Modernization of the Samoan Diet," Ecology of Food and Nutrition 12, no. 1 (1982), 49-60.

88 Bennett, Natives and Exotics, 15-27. 
present. ${ }^{89}$ Soldiers' reflections on their engagement with Pacific islanders are expressed in their published memoirs. ${ }^{90}$ They refer to items generously exchanged with the local population such as the stories of 'Moa' (Dorothy Lamour), Glen Miller, the Samoan anthem ('you are my sunshine'), the use of 'khaki Tee shirts' and 'mills and boon' novels. These indicate how symbolic material items were subtly filtered into Samoan daily life. ${ }^{91}$ The thesis explores the ways in which women were active in using and giving meaning to the new commodities and cultures brought by the war. Samoan women were the principal agents for filtering 'pop culture' into Samoan society. Aggie Grey is an example of this historical agency. ${ }^{92}$ Her role as an hotelier allowed her to import American items for her guests and to provide an avenue for Samoans to access popular culture that provoked a mixture of emotional experiences.

\section{Women's sexual encounters}

The last aspect of Samoan women's wartime experiences that this study explores (in chapter 6) is their sexual encounters. These were the most provocative of all the wartime experiences because the intimate exchanges with the US marines and the babies that sometimes resulted presented a challenge to cultural expectations and post-war social relationships. Samoan society was forced to confront the nature of these new crossings, creating a series of responses that have come to define the overall character of women's wartime lives. The high incidence of illegitimate children meant that specific practices, essential for sustaining familial connections and sustaining cultural power structures, were unable to take place. Social panic resulted from this experience. This led to the shaming and stigmatising of women who had children with American servicemen. Those who did not have children did not suffer the same fate.

The perception that Samoan women's sexual encounters with American servicemen were characterised by an unrestrained morality on the women's part ignores other factors that shaped these encounters, including sexual violence and women's bodily

${ }^{89}$ Michener, Tales of the South Pacific.

${ }^{0}$ John J. Carey, The Marine from Boston (Boston: Garrett Park Press, 2000); Michener, The World Is My Home: A Memoir.

${ }^{91}$ Bennett, Natives and Exotics. See also Joanne Hollows, Feminism, Femininity and Popular Culture

(Manchester: Manchester University Press, 2000).

92 Fay Alailima, Aggie Grey: A Samoan Saga (Honolulu: Mutual Publishing Company, 1988). 
knowledge and preparedness. These two elements are significant because they affect individuals' understanding of their encounters.

Using the gender approach of 'sex as power' to frame Samoan women's sexual encounters, this research reveals how the idea of sex and its ultimate consequence, reproduction, weighs heavily on how the war is remembered. Women's and society's silence has veiled the sexual violence committed against Samoan women by American GIs for more than 70 years. This finding raises new questions about the significance of these wartime encounters. This study shows that Samoan women had a variety of sexual encounters during the war and their narratives speak volumes about the pain sometimes associated with these life-changing moments.

The four aspects of Samoan women's wartime experiences that I have outlined above have never been addressed together in Samoan history. Revealing these aspects of women's experiences will inform this generation's understanding and appreciation of Samoan women's experiences and, perhaps, help break the silences surrounding this part of our shared experiences as a society. The study is a celebration of their lives as well as an acknowledgement of their responses to the challenges they faced as Samoan women during World War II.

\section{An oral history}

Oral history has been vital in bringing Pacific islanders' experiences of the war into the historical record and it is the principal method used in this study. The persistent absence of Samoan women's narratives in the current historiography demanded participation from the generation who experienced the war.

For this thesis I conducted interviews with thirty two women from Manu'a, Tutuila, Upolu, Savai'i and Manono. The interviews were conducted in New Zealand, Samoa and American Samoa. The interviewees who consented to participate in this project are now in the twilight of their lives with ages ranging from 83 to 105 years. (One other interview was with an individual who shared her mother's memories of the war years). They experienced the war when they were between the ages of 10 and 37. This immediately presents a limitation as well. These are the only memories I was able to access in the duration of the fieldwork. The experiences of women who lived through 
the war as adults are now inaccessible. However, the interviewees' memories of their mothers, although limited, may still allow us to access some stories about adult Samoan women's wartime experiences.

One of the advantages of these women's testimonies is that they captured several layers of memories. The first layer is usually the activity or the event as they saw it as young people. As children they absorbed the conversations, words, views and attitudes of the adults about the war without any filters. The second layer of meaning comes from their individual understanding of these events when they happened. The third layer of meaning comes from the women's reflections on their wartime lives; after years of living they have revisited their their wartime lives in these interviews.

As seen in the map in Figure 3, the women are from different parts of the Samoa islands. Some of the women were still living in the same villages that they lived in during the war. Others, as indicated by their location during the interviews in Figure 4, have migrated outside of Samoa and their wartime experiences have become travelled stories. They are also from different parts of the social spectrum with different levels of access to social capital. Two of the participants are former politicians. ${ }^{93}$ All these factors have had a bearing on how they remember their wartime lives.

\footnotetext{
93 Tuala Tiresa M. Hunter-Malietoa was the second wife of the late Head of State of Samoa, Malietoa Tanumafili II. She was an educator and later became a politician in Samoa. Tuala was the leader of the Samoan Christian Party. Asuega Faamamata Lauvai is a former Senate member from the Maoputasi district, in the $32^{\text {nd }}$ Legislature of the Government of American Samoa.
} 


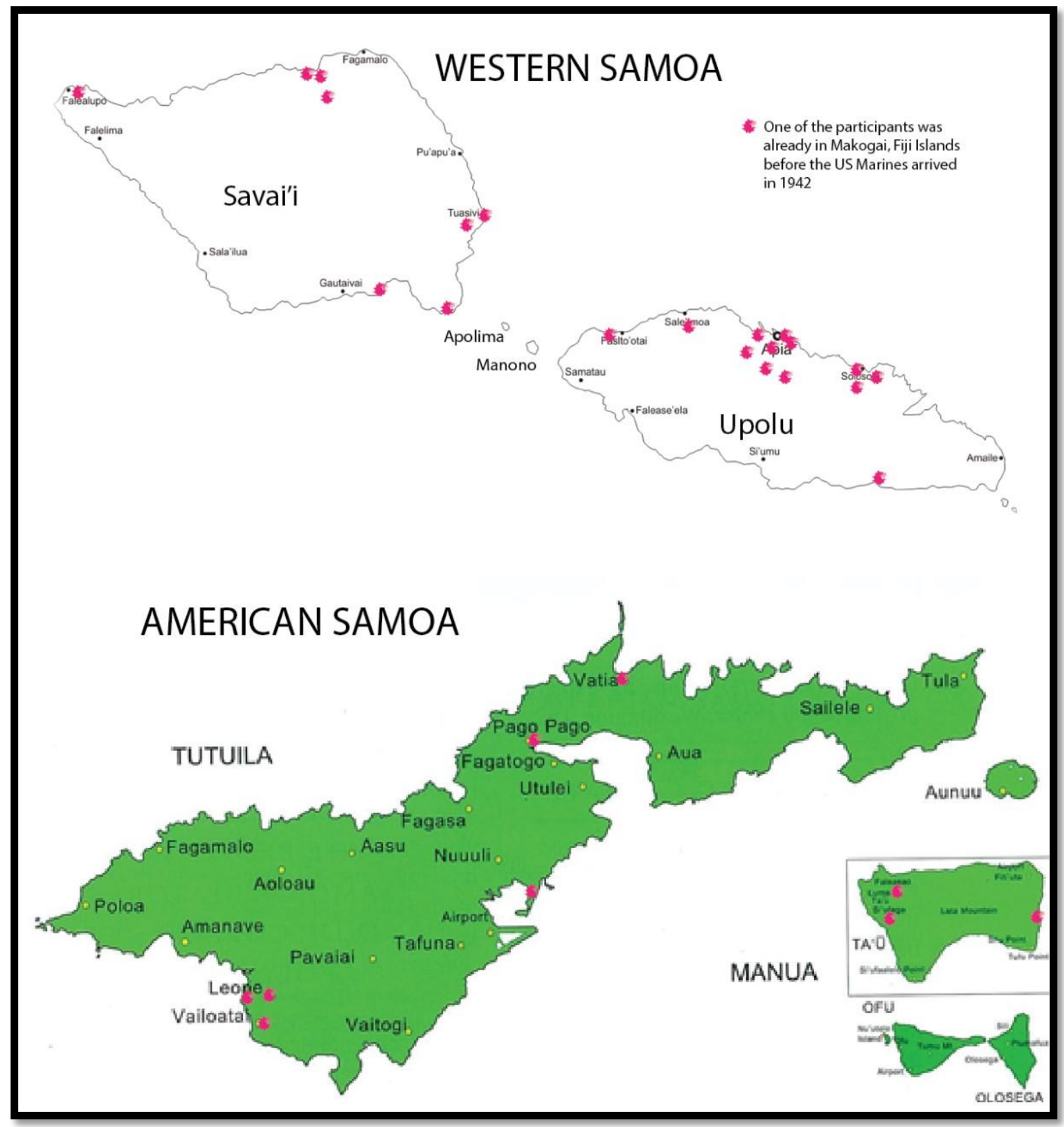

Figure 3 Location of interviewees during the Second World War. 


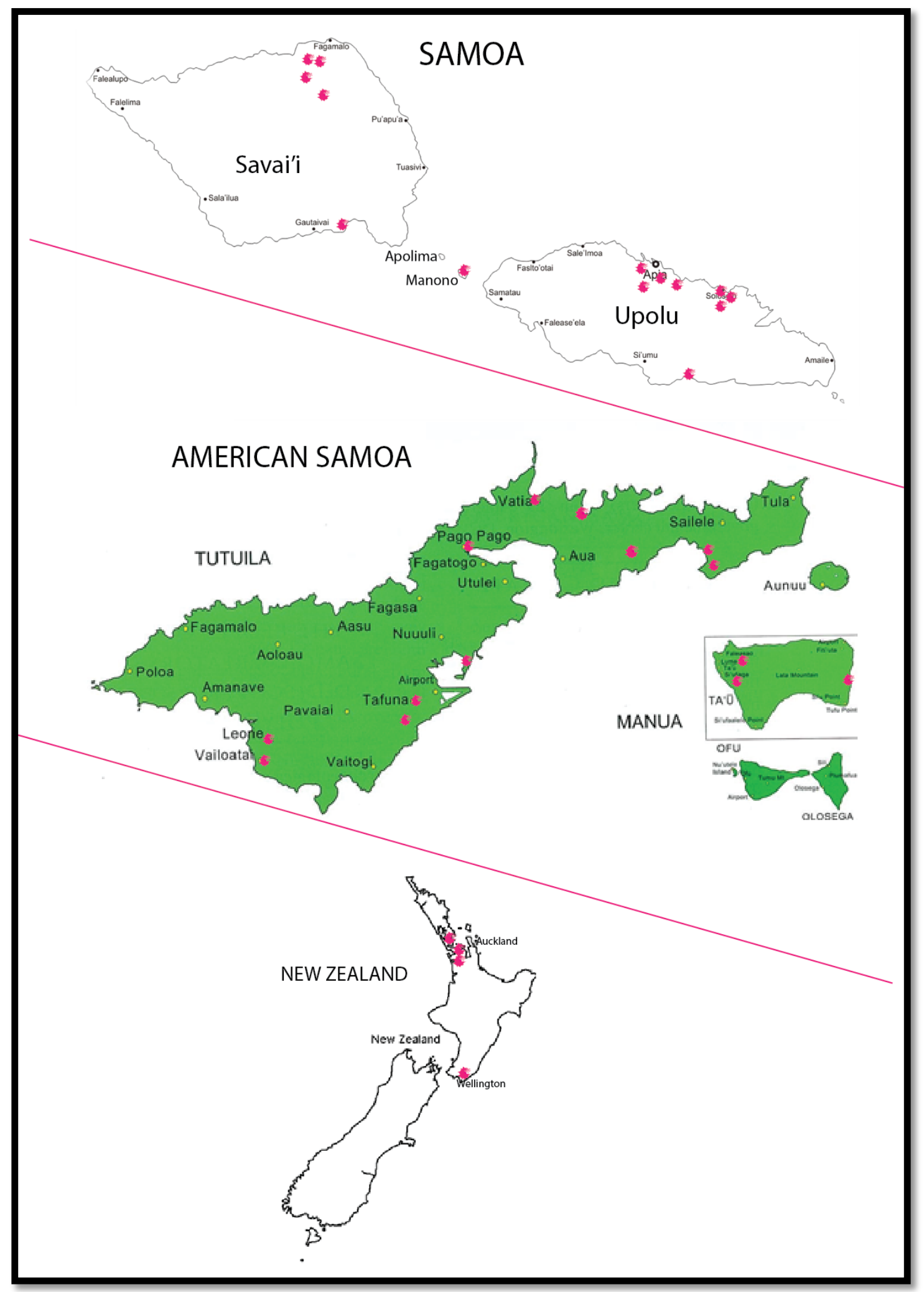

Figure 4 Location of interviewees during the interview process in 2014. 
Identifying and accessing these women has been a race against time and old age. There were also social contours that required attention and understanding. As an indigenous researcher from Samoa, I am aware of my obligations to the rules of academic research as well as my responsibilities to the community that I am researching. This is also the home I will return to when the research is finished. On the one hand, I hear Scott's call that the academic pursuit of gender history demands that researchers disturb the ground on which they stand. ${ }^{94}$ On the other hand, I must respect the culture within which I live. The success of this research was dependent on balancing these two traditions with respect to the Samoan women, whose history I sought. Navigating the two required me to do what the old Samoan voyagers did at the dreaded reef channel at Taga; I had to learn to count the waves like Salemuliaga to reach the safety of the shore. ${ }^{95}$

Because I was well aware of the stigma and shame surrounding the history of Samoan women and the war I used a snowballing method (rather than using advertisements or social media) to discreetly identify participants. This included participating in activities such as bingo games, village group meetings, women's fishing parties and attending cultural functions, including funerals. Cultural knowledge and skills ranging from knowing the oratory language, the fa'alupega (honorifics) of villages and their anthems to playing Bingo, weaving and fishing for 'palolo' were all crucial to the process of developing a rapport with the guardians, ensuring a safe passage to access the 'woman'. ${ }^{96}$ I developed a rapport with the guardians, mostly daughters and granddaughters of the 'wartime women', who would either allow me to approach their mothers for permission to interview them or decline my request altogether. The guardians were key to the success of this research.

Once I had identified potential participants, understanding the different physical and social contexts in which the women live was a crucial to gaining access to them. An understanding of the old chiefly connections and events that have shaped the socio-

\footnotetext{
${ }^{94}$ Joan W. Scott, “Response to Gordon”, Signs 15, no. 4 (1990), 860

95 'The phrase, 'E faitau galu Salemuliaga i le ava i Taga' - Salemuliaga counts waves at reef channel in Taga', has multiple meanings. Here it refers to careful timing and navigating to ensure a safe passage through the reef at Taga.

${ }_{96}$ Palolo worm (Palola viridis) is a delicacy in Samoa. The rising of the palolo occurs in the last quarter of the moon in the months of October and November. This is an annual ritual to fish for the epitoke of the palolo which are diligently fished with nets for only a few hours at dawn and are either eaten raw or cooked. It is an acquired taste.
} 
political relationship between the islands of Savai'i, Upolu, Tutuila and Manu'a is important to understanding people's demeanour and sense of pride in their identity. Samoans have a strong belief in their ancestors' spiritual essence and co-exist with them, sharing the same space. The Manu'a islands has a reputation amongst the Samoan people as an ancestral origin and spiritual place. Like the performances of conversations about women and war, references to Manu'a are often filled with talk of 'aitu' - ghosts. The best ghost stories in Samoa come from Manu'a, where there is always references to a host of legendary Pacific royalties who visited the island group. The island of Ta'u for example is commonly described as an eerie place where 'e te vaai atu lava o taavavale mai atigi po'o i le matafaga' - you see skulls rolling on the beach'. My mother was raised with this history and she passed it to me as a warning. On arrival in American Samoa I was warned again of the same 'beings' and was advised that I had to find the 'right' family to stay with and get their protection. I had with me two one litre Le Vai bottles filled with holy water, a rosary, a scapular and a little prayer to recite in case something 'spiritual' happens. As a contingency plan, I had group of Catholic nuns in Upolu who prayed while I ventured out to the furthest corner of the archipelago with such a ghoulish reputation.

Understanding the Samoan family setting and how the elderly are looked after required a consideration. Samoans in Samoa live in open houses in the village. The elderly normally reside in the main fale (house) where they are watched by their children and close relatives in the surrounding houses. So although they may be the only person in the open house, they are never alone. It is therefore difficult to be discreet within such a tightly knit familial community and this influenced the method used to access the participants in Samoa. In Auckland the interview environment was a lot quieter, enclosed and mostly without an audience.

The delicate age of the participants affected not only the time of the day at which the interviews took place, but the duration of the interviews as well. The average length of the interviews is approximately one hour. The first interview was at a home for the elderly in Auckland. This was the longest interview, lasting two hours and it was the most interrupted interview as well because of hospital routine checks and administration of medication and meals. One interview was called off because the participant was emotionally affected while reflecting about her traumatic wartime 
experience. I tried as much as possible not to interrupt the participants' daily routines, to ensure that my presence did not affect their meal times and the taking of medications. With the exception of the first interview, all the interviews took place in the participants' homes.

As per Samoan etiquette, the interviews began with the formal Samoan greetings, the faatulima, done in the oratory language. This is where I recited the village honorifics ensuring that each of the participant's chiefly titles was laced into these cultural notes of salutation. At this short yet powerful moment of greeting the participant, one acknowledges the living sources of history. The Samoan protocols are done in oratory Samoan.

Choosing the right Samoan words was vital. For example, I chose to use the word, 'saili - to seek or to appeal' rather than the word 'su'esu'e - to question' in the Research Information Sheet and during the interviews. The former implies a genuine quest for new knowledge from the elders, while the latter suggests an interfering behaviour. Positioning myself as a seeker of their knowledge is less arrogant than to 'interrogate'.

In Samoa, deportment when meeting face to face with an elder, that extremely spiritual moment for both the interviewer and the interviewee, is also important. When I addressed the women asking them to assist in the writing of Samoan women's history they all reticently saw themselves as unworthy of being in the history books but they thanked the project for thinking so highly of them as sources of history. I believe my knowledge and application of the Samoan language greatly assisted in breaking the ice between myself as the Samoan researcher and the Samoan wartime women.

There were instances during the interviewing process which were more challenging than others. I discuss two examples to indicate how I resolved these encounters. All the interviews were conducted in front of an audience who were family members, mainly children and grandchildren. The presence of the family gave women the courage tell their stories because they could ask their family members to clarify the dates and names of people and who they are. On the other side of the same coin, having an audience meant that I had to carefully find the right words to ask questions about sexual encounters. I observed that the adult males of the family would sit away from the 
audience, listening in on the interviews. I noticed also that they distanced themselves when I began to ask questions about sexual encounters.

During the interview session in Savai'i I was invited by a carer to sit on the interviewee's mattress with them because of a hearing impairment. As a Samoan one must not cross such spatial boundary, reserved only for close family members. To resolve the situation I requested if the granddaughter would sit with the participant and repeat my questions to their ear. The family agreed. The real challenge then came when I changed from the normal everyday Samoan language into the metaphoric Samoan as a way to hide the carnal knowledge from the young teenager and her brothers and sisters in the audience. A quick slap on the girl's lap showed the interviewee's disapproval of the subject matter and the questions asked. This was followed by the audience's laugh which broke the uneasy silence. The young woman said to participant, 'You have to answer it because the lady asked it', whereby I reminded the participant that they did not have to answer the question. All the participants responded differently in terms of their reaction to the questions but eventually answered the 'hard' questions asked of them.

The interviews were conducted mainly in Samoan. Using the Samoan language in the interviews was extremely important for this research. Having the participants reflect on their wartime lives in the comfort of their own vernacular helped to extend and refresh their memories. Participants who could speak the English language were able to respond to the questions in both languages. Only one participant requested to have the interview in English because she found it difficult to remember things in the Samoan language. The interview question guide was given to the guardians and to the participants before the interview so that they knew what the research was about. Although I had the question guide in Samoan and English, I had to ask the questions in the oratory language. Conveying the Samoan voice as the interviews changed their form from oral to the written language is also very important. I was apprehensive that the Samoan voice was beginning to be eroded through the translation of the interviews into the English language. To resolve this problem I have left some parts of the quotes in Samoan alongside the English translation.

I also made use of village anthems as part of the interview process. Village anthems are historical records of significant accomplishments and heroic acts of power which later 
generations recite to recall the greatness in their pedigree. Children learn these anthems at village gatherings and they are always the 'go to' song at gatherings to entertain visitors or when one is traveling and misses the village. Sometimes, in a very new practice that is now seen in Samoa, the village anthem is sung at the funerals of men and women of rank to farewell them on their final journey. As an oral culture, singing and dancing to these anthems is a form of remembrance. I employed them to pause interviews so that the participant could steady their nerves, recollect their memories and regain the courage to tell their stories. In the village of Solosolo, one of the participants was nervous about reflecting about the war. As a strategy, I started to talk about her village and its history and as I sang the first line of the anthem she joined in the singing and got up from her chair to dance. When we finished singing, I asked her of her earliest memories of the war ${ }^{97} \mathrm{I}$ have discussed the details she gave in reply in Chapter Six. A similar thing happened at Matavai, Safune, where the participant sang her village anthem which tells the story of the creation of the village and its most important feature, its legendary village pool. ${ }^{98}$

The generation of women who contributed to this research are elders in their villages and are watched over protectively by their children and extended family. As a Samoan, my culturally inscribed role makes me part of that guard. I am an insider. Yet my role as a researcher complicates matters and as a Samoan researcher with questions I became an outsider inside at this juncture of relations. Furthermore, my close cultural proximity to the subjects makes the task of researching critically challenging because the personal stories they tell are also family histories. Revealing them to an outsider inside may be in an individual's best interest but perhaps not the family's. Part of my role was to conciliate all these levels of anxiety.

Being an insider, you are at the mercy of the participants' demeanour and predilections. As an inside researcher, we must be prepared to allow the participant to ask questions about our identity because these are important to Samoans. In Tutuila I was interviewed by a participant before I entered their fale tele. I was told not to come in because she had questions. In Samoa it is rude to speak to an elderly person while standing so I sat by the entrance of the fale tele and answered her questions which included, 'o fea e te

${ }_{97}$ Tautautasileniualeotaleuluaiali'i Leota, interview by Louise Mataia -Milo, 29 August 2014.

${ }^{98}$ Faapusa Faumuina, interview by Louise Mataia-Milo, 17 October 2014. 
sau ai? / where are you from, o ai oe? / who are you, $\mathrm{O}$ fea lou nu'u? / where is your village, $\mathrm{O}$ ai le matai o lou aiga? / who is the chief of your family, $\mathrm{O}$ ai na fai atu e te sau ia te au? / Who directed you to me?' After I was interviewed the participant stood up and went into the living room of the house where she had breakfast, watching me from inside the house. There was an exchange with other members of the family inside the house in Samoan. The participant took another look at me and I smiled back to her. By this time, I was totally exposed to the sun. When the participant finally decided to allow me to enter she called one of the relatives to bring me into the house, closer to her table where I had to do the greeting formalities in Samoan.

A common question that came up in the interviews was the question of intent. What are you going to do with this information? How much money are you going to make from this? Will I see you again? I explained the academic commitment for the research. As a Samoan researcher, I am culturally obligated to take that trip again to thank them in person, after the research is done. It is a return journey that I am excited and anxious to take because most of them will not be there. This is a part of the afterlife of the research that one must be prepared for.

The interviews themselves were structured to record how the women remembered the four aspects of their experiences. They also reflected on how they thought about their wartime experiences after many years have passed. Alessandro Portelli, who argues for the value of oral history of non-hegemonic groups, posits that the unique element in oral sources that no other sources possess in equal measure is the speaker's subjectivity: 'Oral sources tell us not just what people did, but what they wanted to do, what they believed they were doing, and what they now think they did. ${ }^{99}$ This is an element that is further enriched with the consideration of gender perspectives asserted by Scott. ${ }^{100}$

Oral history tells how individuals made sense of their pasts. Portelli highlights the importance of the oral history method of collecting data by saying: 'Interviews often reveal unknown events or unknown aspects of known events. They always cast new light on unexplored areas. ${ }^{101}$ Through individuals' stories we can see a variety of

\footnotetext{
99 Alessandro Portelli, The Death of Luigi Trastulli and Other Stories: Form and Meaning in Oral History (New York: Stage University of New York Press, 1991), 50.

100 Scott, Gender and the Politics of History, 51.

101 Portelli, The Death of Luigi Trastulli and Other Stories, 50.
} 
wartime experiences from their point of view. The benefit of the oral history approach is the intimacy of the participants' voices in telling their stories. The women interviewed for this study have become agents of history by participating in the expansion of the currently narrow frame of Samoan historical scholarship.

Obsessions with silence can also lead to a loss of history. Over time, the keepers of these silenced histories disappear without sharing their stories. This further obscures women's wartime narratives. An example of such a historical problem is the case of Samoan women's World War I experiences, which are an area that the embodied voices of Samoan women cannot contribute to anymore. Falgout and others have outlined the same problem in Micronesia. ${ }^{102}$ The lesson here, and thus the reason for this project, is that perhaps it is the historians' professional obligation to be more vigilant and proactive in recognising areas of historical research that need to be explored.

This thesis offers an opportunity for Samoan women to make history, to share their wartime lives as they understood them. They lend their agency to Samoan wartime history, revealing the complexities of their lives that challenge the way we have come to accept and appreciate their experiences. Natalie Zemon Davis, who explored ordinary people's lives in sixteenth century France, acknowledged that her considerations are 'partly my invention, but held tightly in check by the voices of the past. ${ }^{103}$ In this thesis my interpretations are held in check by the conversations with, and understandings of, the Samoan women who lived through the Second World War.

I argue in this study that social change is produced through daily encounters, changing practices and shifting understandings that continuously negotiate what normality is. All these aspects constitute personal agency. The war generated unusual circumstances that transformed ordinary people's lives. Oral history is the platform that allowed the women to recount their own experiences and observations and also to reflect on their wartime lives, bringing their agency to the fore. David Shaw's comprehensive discussions of agency and the recovery of self warns about the tendency of oral

102 Lin Poyer, Suzanne Falgout, and Laurence M. Carucci, The Typhoon of War: Micronesian Experiences of the Pacific War (Honolulu: University of Hawaii, 2001).; 217-8, 315-20.

103 Natalie Zemon Davis, The Return of Martin Guerre (Cambridge: Harvard University Press, 1983), 5. 
historians to atomise or overemphasize the personal self in the narratives. ${ }^{104} \mathrm{I}$ acknowledge this risk and the many other limitations of the oral history approach. However, given the fast deteriorating state of the oral sources, this study chose to highlight personal agencies as a way to allow Samoan women's wartime experiences to enter the historiography.

The women's reflections as they narrate their wartime choices, actions and individual desires reveal their indigenous agency in how they see their lives as Samoans. They have been given the chance to narrate their own experiences as historical agents in the process of making history. Allowing Pacific people to tell their lives from their own perspective is an important part of Pacific history. Exploring Samoan women's wartime lives and their personal agencies reveals the variety of different experiences that existed within a context that is often blurred in general histories. Historians of the Pacific such as Robert Nicole and Martha Kaplan in their studies of Fiji also draw on personal agency to reframe and rediscover the actions of ordinary people neglected by previous historians. ${ }^{105}$

This research shifts away from the dominant practice of viewing history through the agencies of political and cultural elites. This study gives the ordinary woman's view, the villager's voice. Analysing Samoan women's wartime experiences shows how they, as Samoans, as islanders and as women saw and interpreted their wartime situations. Their responses to their wartime realities as ordinary people reveal that these Samoan women made history in their own terms.

Through their narratives we discover their interpretations and how they assign new meanings to old understandings, linking their pre-war selves, their wartime lives and their present. All of the women understood that they had no control over their situation in the larger scheme of things. Yet at the village and family level, they were able to have some of control over certain aspects of their lives. Although they had to conform to the emergency regulations, they were still able to exercise their personal agency in the way

\footnotetext{
104 David Gary Shaw, 'Recovering the Self: Agency after Deconstruction' in Nancy Partner and Sara Foot's The Sage Handbook of Historical Theory (Sage, London) 2013, 486-490 105 Robert Nicole, Disturbing History: Resistance in Early Colonial Fiji. (University of Hawai'I Press, Honolulu) 2011. 9-10, Martha Kaplan, "Meaning, Agency and Colonial History: Navosavakadua and the Tuka Movement in Fiji. American Ethnologist 17, no.1 (1990). 10-11. See also: Browen Douglas, Across the Great Divide: Journeys in History and Anthropology. (Harwood Academic Publishers, Amsterdam). 1998. 19-21
} 
in which they Samoanised novel wartime situations, encounters and interactions. While some experiences were happy and were warmly recalled, others were violent. Talking about these experiences allowed the individuals to confront their memories and to consider how these wartime events have shaped their lives. The women's remembrances of their wartime selves illuminate the many connected layers of previous experience and personal agency that have accumulated over time.

To complement these oral histories this thesis also draws on a variety of other historical sources. Contemporary newspapers and magazines have been very useful as have been the memoirs of soldiers. Where possible archival sources have been used to address some of the questions. For example, the records of the Catholic Diocese of Samoa and Tokelau reveal how established institutions transformed both in practice and in frame of mind to accommodate the war. The US Naval records highlight developments in the areas occupied by the US troops. The American Samoa Archives did not have any records available to me during the time of the study. The photographs from the Samoa Archdiocese Archives at Vailima provided a representation of how Samoan young women looked before and during the war. The archives of the New Zealand administration have proved invaluable in corroborating some of the stories that the women referred to in the interviews. I have only used only a fraction of this rich archive.

There were also limits to which the archival sources I could access. Time and funding constraints hindered access to the NARA records in the United States. I was only able to draw from some of the records of the Government of American Samoa, made available by other researchers. It is important to note that much of Samoa's wartime history sits in the US naval archives in the form of administrative reports and correspondence, yet to be evaluated and analysed by interested scholars. Some of the military records to do with military disciplinary laws and court martial cases during the Pacific War were part of the disposable records of the US military command. Communications with NARA personnel indicated that these records were destroyed after the war. They are also expensive for Samoan based researchers to access because they are in San Francisco and the files have to be inspected by the archivists before they can be released for viewing. The personal narratives are also becoming difficult to access. Diabetes and hypertension, as well an increased outward migration of elderly 
Samoans to NZ and the United States for medical care, intensify the fragility of these histories.

Five further chapters and a conclusion now follow. Chapter two provides a portrait of Samoa before the Second World War and the inter-war decades into which the women interviewed were born. The central discussion in this chapter draws on the important social, political and economic changes, trends and processes that govern Samoan behaviour and social transformation.

Chapters 3-6 focus in turn on the four different aspects of Samoan women's wartime experiences outlined above. Beginning with the war's arrival in Samoa, Chapter 3 explores the different responses to war emergency regulations and how the wartime circumstances subtly transformed women's roles. The participants' insights become the windows through which we see the wartime vistas and Samoans' responses to the social upheaval that brought about social transformation. Chapter four examines the extent to which the war influenced women's engagement with the church and how this shaped their lives. Chapter five examines Samoan women's engagement with wartime popular culture including candies, movies and dancing. Finally, chapter six explores Samoan women's wartime sexual encounters. 


\section{Chapter Two. Lesolosolou - Samoa on the eve of the Second World War}

Lesolosolou is an old Samoan term, seldom used today. A literal translation, when divided into three parts, is le/the, solosolo/slow moving, u-/to bite. Robert Louis

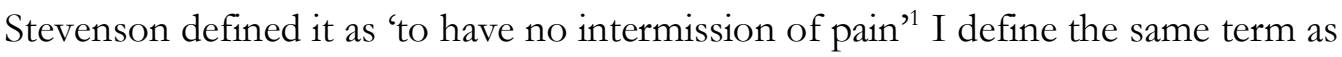
'continuous struggle.' The term is defined in the context of hosting a malaga (ceremonial visiting parties), where visitors have overstayed in a village, or when visitors constantly arrive, draining the host's hospitality and resources. It has a similar meaning to the Maori phrase kawhawhaitonu matou or 'struggle without end'. ${ }^{2}$ Lesolosolou encapsulates the state of affairs on every level of the Samoa islands in the first 30 or so years of the twentieth century in which outsiders claimed the islands for themselves while Samoans ceaselessly struggled to make sense of it all.

This chapter explores the entwined political, social and cultural forces that shaped Samoan women's lives in Samoa's not so roaring 1920s and 1930s. In doing so, it seeks to outline the historical processes, institutions and events that influenced their life experiences. I begin by discussing the diverse backgrounds and experiences of some of my interviewees to illustrate how the various social, political and economic forces already at work shaped Samoan women's lives. The second part of the discussion examines the colonial influence on the Samoan society that the interviewees were born into during the interwar period. It considers how both Samoan and introduced institutions came together to influence women's lives in the first half of the twentieth century. The final part of this chapter then explores the cultural institutions and other social forces that shaped Samoan women's daily lives and their roles before the war. These institions such as the aualuma and the taupou and the relational concepts such as the covenant or the feagaiga and va tapui'a were already areas that were continually contested and heavily influenced by the Christian missionaries by the 1930s. An understanding of this significant part of Samoan women's lives is fundamental to understanding how they responded to the arrival of the war.

\footnotetext{
${ }^{1}$ Robert Louis Stevenson, A Footnote to History: Eight Years of Trouble in Samoa (Auckland: Pacifika Press, 1996, $1^{\text {st }}$ ed.1892), 6.

2 Ranginui Walker, Ka Whawhai Tonu MãTou = Struggle without End (Auckland: Penguin, 2004).
} 
The discussion ultimately shows that women's wartime experiences were formed against an evolving backdrop that melded old and new, global and local manifestations of social and political forces. Individuals and groups alike had to negotiate, balance and reorganise their lives and the terms of their engagement with the dynamic nature of their daily environment. Their understandings of the prevailing contexts and rules were reflected in their responses to the war, which brought change on a scale that Samoans had not before encountered.

\section{Ordinary lives}

It is impossible to capture an archetypal pre-war experience because despite Samoa being a small indigenous society, there are many elements which can make individuals' experiences very different. Factors such as one's geographical location, social capital, personal situation and religious denomination all had a bearing on the pre-war experiences of my interviewees. Furthermore, the Samoa islands was a society divided into two political territories under the agents of two different government and their different systems of rule. All these factors affected life in pre-war Samoa. The lives that follow illustrate this point.

Ana Savea and Fa'asalafa Leota are both from the village of Solosolo, on the north eastern side of Upolu, and lived near each other yet their lives before the war were very different because of their parents' background and the chiefly families they come from. Ana was born in Solosolo in 1927. She had an older brother. Both her parents were from Solosolo but had paternal ties to Amaluia in American Samoa. While she was still young, Ana's father left the family and remarried and moved to live at a nearby village. Her mother with the support of the whole family raised Ana and her brother. Ana remembered how her mother, who only had a sister, did the chores of a woman as a weaver and was involved in the women's group as well as working the plantation with her older brother to feed the family. She attended a school at Solosolo run by a villager named Salevao but left when she was eight years old to attend the Catholic convent school for girls at Moamoa. Here, Ana joined other young Samoans girls who had all come from different villages to receive a Catholic education. At the boarding school, the church doctrines of purity, piety and virtue were the main concerns. Girls were taught domestic skills in cooking, knitting, crocheting, and agricultural skills. Ana, 
however, claims that the most important thing to school was the 'kapite' - the catechism.

As young students, our duty was to go with the nuns to help sell the kapisi (cabbages) and other vegetables in town. We help load the horse draw cart and go with the nun, who also take the crocheting to sell in town. We give the kapisi to Emelio and other places. We also learned how to plant the kapisi and kaloti. One of our duties as well was to collect the dried breadfruit leaves that have fallen off the tree. We take this to a dug out. We get the cow manure, add it to the leaves and the fill the patch with the soil, and grow the plants on top. That is how the sisters made their money. O le popoto ia o taupousa! - The nuns were smart. However, the most important task of the day was learning the 'kapite'. That was the top priority. We were given books with prayers that we all have to learn the off by heart and they teach us about the church and all that. ${ }^{3}$

Ana stayed at the school for some years before returning to her village and family after the outbreak of the war. The skills she learned from the nuns she applied at home.

Fa'asalafa is three years older than Ana and was much more involved in village life. Born in 1924, she attended a village school run by 'a village man who went to the seminary but came back. ${ }^{14}$ Her birth had marked a turning point in her family history. It was the year that her father, the sole holder of a paramount chiefly title, made a decision that changed her extended family by allowing another relative to hold the title concurrently with him. Thus, the second born daughter was named Faasalafalesuafaoleotatoomata - dividing the Leota Toomata title. As a daughter of a paramount chief and sister to a taupou, Fa'asalafa had a more traditional upbringing than Ana, yet it was also unusual in a way because neither she nor her sister (the taupou) followed the strict traditions of the taupou upbringing.

There was no one to help. Many people of our village died in the faama'i tele - the big death - so we all had to do our bit to help the family. ${ }^{5} \mathrm{My}$ father and mother were old, but I remember how my father used to go out to the plantation to get food and provide for the family. He was already a

\footnotetext{
3 Ana Peletisala Savea, interview by Louise Mataia-Milo, 22 September 2014, Solosolo, Anoama'a.

${ }^{4}$ Fa'asalafalesuafaoleotatoomata Leota, interview by Louise Mataia-Milo, 30 September 2014, 30 September 2014.

5 'Fa'amai tele' - 'the great sickness'. A common expression referring to the 1918 influenza pandemic. 
paramount chief then, but there was hardly anyone to 'tautua'. ${ }^{6} \mathrm{We}[$ the children] all have to help out. ${ }^{7}$

Faasalafa's narratives illustrate how people adjusted their daily lives and the way they practiced their culture because of situations they had no control over, such as the 1918 influenza pandemic. On top of this, heads of families were not focused on the immediate families but had to cater for the security of the whole extended family as indicated by Faasalafa's decision to split the titular authority.

The second example of contrasting pre-war lives comes from Manono, an island off the west coast of Upolu. Canoes and long boats were the main form of transport to and from Manono and the island is famous in Samoan history as the place where travellers who traversed the busy ocean highway between Savai'i and Upolu would call in to rest before making the last leg of their journey.

Maria Taupau Enesi and Sr. Makerita are both from Manono yet each had different experiences in their early lives. Both women were born in 1924. Makerita, from the village of Faleū, received an informal education within her extended family. She was an eager shadow who followed her paternal aunties to the aualuma and one of the armies of helpers sent around the village by her mother's weaving group to collect weaving materials from other families before joining other youngsters in the preparation of food for the weavers. As we will see in Chapter 4, Makerita's chance wartime meeting with her maternal uncle, who ensured she received a formal education, would change the trajectory of her life.

The happy and adventurous childhood memories that now comfort Sr. Makerita in the delicate years of her life contrast with those of her fellow villager Maria. Although the two women are from the same island, their paths never crossed. 'When I was young, I went to the pastor's school then come and help mother with the housework. ${ }^{8}$ At an early age, Maria succumbed to Hansen's disease (leprosy) and was removed from Manono to the leprosy unit of the hospital in Apia where she stayed for some years before she was shipped off to the leper colony of Makogai, in the Fiji Islands, in 1942.

\footnotetext{
6 Tautua - cultural support. Untitled men fulfil this cultural obligation by doing daily chores at a paramount chief's residence or preparing food for the chief.

${ }^{7}$ F.Leota, interview.

${ }^{8}$ Maria Aigailetai Taupa'u Enesi, interview by Louise Mataia-Milo, 30 December 2014, Salua, Manono.
} 
Maria was 18 years old when she left Samoa, yet she never forgot her mother's determination to travel the long distance to be with her at the hospital.

Many people are scared of lepers then. In the early days, the doctor told my mother that she could not stay at the hospital, but mother insisted she could not leave me! Nevertheless, she travels from Manono every day to be with me until the doctor allowed her to stay, and she did until they took me with other Lepers to Makogai. I have an older half-sister who was also at Makogai. She died and is buried there as well. While I was there, I was longing to get better so I can return home.

Although this thesis focuses on women's wartime experiences within Samoa, Maria's wartime story reminds us that some Samoan women experienced the war outside of Samoa. Maria spent the war years living on Makogai and did not return until after the war.

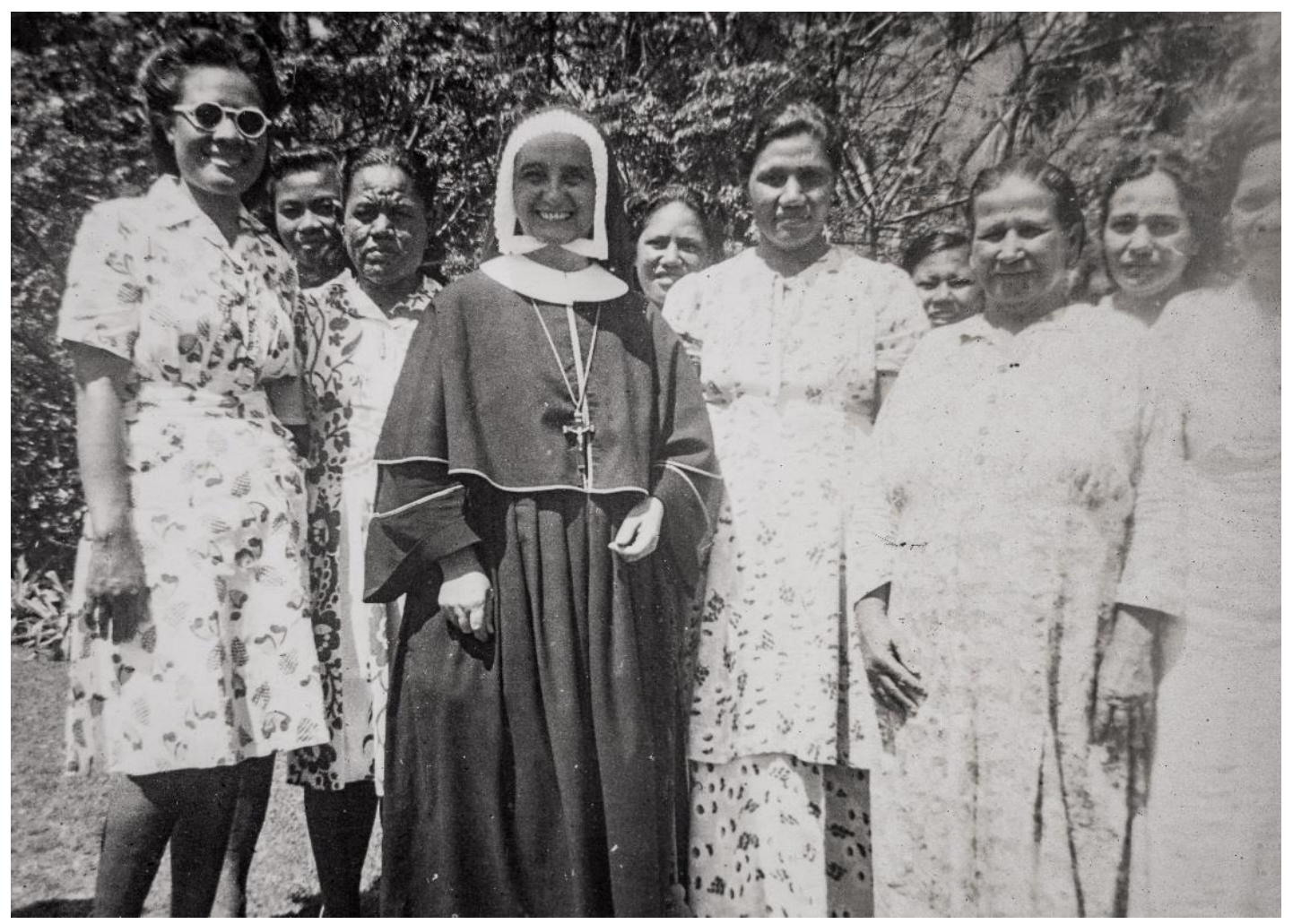

Figure 5 M. M. Jeanne D’Arc at Makogai, Fiji, with Samoan Lepers, circa the 1940s (Source: Archdiocese of Samoa Archives, Vailima).

The third set of examples comes from the villages of Tuasivi on Savai'i, Fititua in the Manu'a Island group and Nu'u'uli on Tutuila. These three locations all help represent

9 Taupa'u Enesi, interview. 
different aspects of Samoans' lived experiences before the war. Isabella Ryan was born at Lalomalava in 1930. Her father, Edmund Stehlin, was of German, French and Samoan heritage. He was in charge of the police and prisons in Tuasivi under the New Zealand administration. As a daughter of a Samoan-born official and as the maternal granddaughter of an LMS minister, Isabella had a sheltered life. She attended the Catholic primary school at Fusi together with her siblings. Her father ensured they had books to read. The family lived in the government compound near the Tuasivi cape and apart from the rest of the village. Her resourceful Samoan mother managed their home and was responsible for budgeting, cooking, nursing and sewing.

My mother baked wedding cakes, baked our bread and ran the whole household... I marvelled at her, and even when they go to government functions, mama knew how to dress, and how to behave, ae la e o i mea e iai papalagi - yet they were going to where there were foreigners. ${ }^{10}$

Isabella's memory of her parents' ability to access resources and food items seldom consumed in Samoan households and their socialising suggests that the family had the social capital to navigate colonial social hierarchies with ease. They were part-European, and they were also part of the New Zealand colonial administration. Even within this calm social circle, Isabella sensed at a young age how her father's family looked coldly on her mother's demeanour and indigeneity. Isabella revealed how her grandmother did not like her mother because she was Samoan, 'but I tell you, e better atu lou tina i loo isi afakasi ma isi papalagi! - My mother is better than other half-castes and foreigners. ${ }^{11}$ These racial attitudes were a common feature of colonial life in both territories. However, in the rural areas, such as Manu'a, people seldom saw racial attitudes flouted in public.

Born in the village of Fitiuta in Manu'a in 1932, Saunia Pa'au recalled that she had a great time growing up. Her life was similar to how her ancestors lived: 'o mea lava mai anamua na fai ai le nu'u lenei ae lei sau Le taua - this village lived and used the old ways before the war. ${ }^{12}$ Saunia recalled the simplicity of daily life when Samoan children's ball games such as kilikiti (Samoan version of Criket), lape, and togi ga nonu punctuated obligations to family and the pastor's school. Saunia described how strict the chiefs of

${ }^{10}$ Isabella Stehlin Ryan, interview by Louise Mataia-Milo, 7 May 2015, New Lyn, Auckland.

${ }^{11}$ Ryan, interview.

12 Saunia Pa'au, interview by Louise Mataia-Milo, 6 December 2014, Fitiuta, Manu'a. 
the village were in the 1920s and life as she puts it was 'faigata - difficult'. Saunia remembered that her education was:

At the pastor's school! The teacher was the pastor and his house was the school. We all brought our little mats women by our mothers to sit on. You take it home at the end of the day and bring it back the next day. Before the war the normal things we did at school was the learning the alphabet, how to write our names and how to write in general. We used the charcoal from the umu to write with. Moreover, at times we used the laufao leaf as books. ${ }^{13}$

Saunia described the simple education at Fitiuta a decade before the war, something that today's generation might be oblivious to. What is significant in this Manu'a village context was that the outlook and orientation of the young girl at school and in her leisure was mostly Samoan.

On the main island of Tutuila, in Nu'u'uli, lives another young woman, Nanatiifaleteleife'auatamalii Savusa, who before the war lived an extremely shielded life due to illness. Born in 1932 Nanati was raised by her maternal grandparents, together with her three other siblings. A year after her mother passed away, her father wanted to return to his village and to take his children with him. Nanati's grandmother however, persuaded her young father, Mageo Ma'e'ele, to leave Nanati and her siblings with them at Nu'u'uli, and carry their maternal surname, Savusa. According to Nanati, her grandmother felt that another woman might not care for her grandchildren. She allowed Nanati's father to visit them, even after he remarried. Not long after this arrangement, Nanati's life took another turn for the worse:

I was little and still in school when $[$ ] became a cripple. I could not feel my legs. You can stab it with a knife, they bleed but I did not feel anything. My grandmother and I travelled the length of Tutuila to find a cure. The hospital told her I was a hopeless case and to just bring me home to be looked after. That was my life for three years, some months and days. I was only 13 then. However, I heard her weeping in the middle of the night. Listening to her cry made me cry as well. Then all of a sudden, I could feel my legs move. I called out to her in the dark about what was happening to me. She lit the lamp and saw that I could wriggle my feet and then tell me that it is a miracle. ${ }^{14}$

\footnotetext{
13 Pa'au, Interview

${ }^{14}$ Nanati'ifaleteleife'auatamalii Savusa, interview by Louise Mataia-Milo, 12 December 2014, Nu'u'uli, American Samoa. Nanati did not name her condition using any medical term. However, her body has the physical symptoms of someone who suffered from Polio. In 1932, cases of infant and child paralysis
} 
Nanati's grandmother was excessively fond of her sick granddaughter and worried for her future. She made sure that Nanati got the best education that the family could afford at the time. Nanati was the only person in the family to travel by bus to attend the feepaying Catholic school while the rest of the household's children went to the local village school. Nanati's grandmother persuaded her other children to help fund Nanati's education.

The last examples to illustrate the different kinds of lives that Samoan young women lived before the war come from the urban areas of Vaiala, in the district of Vaimauga in Upolu and the village of Pago Pago, Tutuila. Both Tuala Falenaoti Teresa Minnah Hunter-Malietoa and Asuega Faamamata Lauvai are now holders of paramount chiefly titles from their families and were prominent politicians in their primes. ${ }^{15}$ These two women experienced the war in the different urban areas of the two Samoan territories.

Born in 1932, Asuega was raised by her older siblings who were already adults with families of their own when her parents died while she was still young; 'Ioe, e faapena lava le mea sa iai, e vaai e le au matutua le au laiti - yes, that was the usual way; the older ones take care of the younger ones. ${ }^{16}$ Asuega lived in the village of Pago Pago, the capital of American Samoa, which as described by Asuega was still very traditional even though it was a capital.

There was the continuous presence of the naval administration but people went about doing what they have always done in the past, living the Samoan way and attending church and school. Our family is humble and we did not have a lot, unlike other half-caste families here at the village but we were alright. ${ }^{17}$

In Western Samoa Tuala's childhood in the 1930s exemplifies the colonial influence, which affected the way that people related to each other at the time. Tuala's father was a part-New Zealander and her mother, like Isabella's mother, was the daughter of an LMS minister. Her father was a land surveyor in the New Zealand administration and her

occurred in American Samoa. Western Samoa Health officials who investigated how infants and children in Western Samoa were infected trace it to frequent interisland travels between Tutuila, Savai'i and Upolu, and children's reaction to drugs for the treatment of yaws, administered through injections either to the buttocks or the arm. See: P.J. Monaghan, Acting C.M.O. to C.A. Berendsen 'Comments on Ielu's Report of July 1'st, 1934 of Savai'i Paralysis Cases'. Aug. 10, 1934. AAEG W3240 950 Box 613 C 311/6/5 1."

ANZ.

15 The matai titles Tuala and Asuega refer to each of these individuals from here on.

16 Asuega F. Lauvai, interview by Louise Mataia-Milo, 16 December 2014, Pago Pago, American Samoa.

17 Lauvai, interview. 
mother looked after their family. Tuala was born in 1924. Her eldest sister, Ivaomalososo'o, died in the pandemic of 1918, together with many of her other relatives. ${ }^{18}$ Her father's European status may have mellowed any resentment of the New Zealand administration: 'My father had European status. He was a surveyor trained in New Zealand. He wanted things that New Zealanders wanted. He was like a New Zealander. ${ }^{19}$ Tuala recalled that the attitudes of the New Zealanders and those who 'were like the New Zealanders' at the time were very different from the attitudes in her later years as an adult: 'It was different in a way that ah you think differently about yourself, that you are more important than the others, you know the New Zealanders! I'm sorry to talk like this [Silence]. ${ }^{, 20}$

Tuala attended Leifi'ifi school with other children of New Zealand officials and partEuropean Samoans. English was the only language allowed in the entire school compound. One of the things she did not like at school was sitting the New Zealand matriculation exams. 'It really was to prove I have something like a European way., ${ }^{21}$ However, outside of school, she enjoyed a more westernised Samoan home environment. Tuala's mother acquired a car and was an active member of a social circle in Apia, including the Aute Club. The Aute club was a group of half caste women who hosted social events in Apia in the 1920s and 1930s to fundraise for different causes. There are no records of this club but they hosted a luncheon for the Governor General of New Zealand when he visited Western Samoa in the 1930s. They were also involved in raising funds to purchase a Spitfire aeroplane for the New Zealand army. The group evolved during the war and became known as the Samoan Mothers' Club, who supported Samoan soldiers who fought in World War II. Tuala's mother was a president of this club for a time.

These nine lives highlight the variety of my interviewees' pre-war experiences. They also illustrate the types of changes that asymmetrically cut through Samoan society in the 1920s and 1930s. Family situations and the church shaped Ana's life at an early age. Faasalafa was bound to traditional obligations because of her father's chiefly title. Her family also had to adapt their daily practices while the extended family gradually

\footnotetext{
18 Tuala Falenaoti Terese M. Hunter-Malietoa, interview by Louise Mataia-Milo, 12 August 2014.

${ }^{19}$ Hunter-Malietoa, interview.

${ }^{20}$ Hunter-Malietoa, interview.

${ }^{21}$ Hunter-Malietoa, interview.
} 
recovered from the influenza. Maria and Makerita from Manono never crossed paths but both were influenced by circumstances beyond their control. Maria's illness sent her far away from Samoa and (as we shall see) Makerita became caught up in another relative's plan. Nurtured in political engagement at a very young age Nanati developed a perceptive character and an awareness of the social issues to stand up for despite her physical frailties.

Family situations also dictated Asuega's early life where her older siblings directed the way for her. The bustle and congestion in Pago Pago caused by the presence of the navy contrasted with the quiet and remote corners of Samoa where Saunia and Isabella grew up. Isabella's life also differs because of her father's colonial and racial status that allowed her access to experiences not available to Saunia. This does not make Saunia's pre-war experiences less important. Tuala and Isabella perceived Samoa from elevated social positions because of their parents' roles in the New Zealand administration. Tuala's early life experiences highlight the colonial aspect of Samoan society that she was born into where race was a currency to access social capital. These nine lives are not representative of the entire population, but they provide us a glimpse of what life was like in the two territories before the war.

\section{Colonial social control}

The early 1900s, especially the 1920s and 1930s, was a period of power conflict between the colonial administrators who were trying to exercise political control and the Samoan chiefs who opposed the policies that restricted their cultural practices. The two administrations' racial and paternalistic attitudes led to disastrous ends such as the pandemic. Some of the participants in this research lived close to the epicentres of political protest in the 1930s in the two territories while others lived in more remote areas. All however were influenced in some way by the policies of the colonial administrations in the inter-war decades.

The women interviewed for this study were born into a Samoa which had grown accustomed to dramatic change. The factional wars that dominated the nineteenth century and the violent and non-violent transformations they brought were still in the living memories of their parents' generation. The wars had kept Samoa in a state of 
instability and none of the factions achieved their long-term goal of ruling Samoa through the chiefly titles. Instead, the chiefly factions' entanglement with foreign interests created a situation that allowed foreign penetration of Samoan politics and reconfigured many aspects of Samoan society. ${ }^{22}$

The titular contests, the last of which occurred from 1889 to 1899, allowed Britain, Germany and the United States - who had themselves enflamed the chiefly factionsto enter the contest for power. This resulted in the partitioning of the Samoa islands in 1900, following the 1899 Tripartite Convention, sending Samoan society along two separate political paths. Germany colonised the western islands (including Savai'i and Upolu) while the United States was ceded the eastern Islands (including Tutuila in 1900 and the Manu'a group in 1904). Samoans had to adapt to the new change in power. One can argue that Samoa finally found a prolonged peace and a sense of stability with the foreigners in power but at the cost of their indigenous autonomy.

Under formal colonial administration, metropolitan interests further drove the transformation of the Samoan Islands. The United States' interests were primarily strategic. As a territory of the United States, the US Navy administered Tutuila and the Manu'a islands until 1951 when a civil government took charge under the Department of Interior. ${ }^{23}$ The Navy transformed Pago Pago into a coaling station for the US Pacific squadron and then into a naval base on the eve of World War II. ${ }^{24}$

Germany's engagement in Samoan affairs was to safeguard German economic interests. Foreign planters (mainly Germans although there were others from Britain and Denmark as well) had developed Samoa's agricultural potential in industrial agricultural products such as copra, cocoa and rubber. The Hamburg trading company Deutsche Handels-und Plantagen-Gesellschaft (DHPG) dominated commercial and agricultural activities in Samoa and introduced Samoans to the world money economy and capitalist culture. ${ }^{25}$ These systems were foreign to the Samoan people who were still practising the subsistence and reciprocal system they inherited from their ancestors. The DHPG

\footnotetext{
${ }^{22}$ Kennedy, The Tropical Frontier, 223; Amerika Samoa Humanities Council, A History of American Samoa (Honolulu: Bess Press, 2009), 257-9.

23 Amerika Samoa Humanities Council, A History of American Samoa, 248-52.

${ }^{24}$ Kennedy, The Tropical Frontier, 12-6, 195-201.

25 Doug Munro and Stewart Firth, "German Labour Policy and the Partition of the Western Pacific: The View From Samoa," The Journal of Pacific History 25, no. 1 (June 1990), 86.
} 
operated mainly on Upolu and Savai'i because of the availability of flat land suitable for mono-agricultural plantations. For a while, the copra and cocoa plantations developed into a lucrative undertaking that generated a demand for labour that Samoans were not accustomed to. The Germans resolved this labour problem by importing Melanesians and Chinese to work the plantations as indentured labourers. ${ }^{26}$

The First World War abruptly ended German rule in Western Samoa. New Zealand forces, as part of the British Military occupation, took over from Germany without public opposition in August 1914. ${ }^{27}$ In 1920, Western Samoa became a League of Nations Class C mandate to be administered by New Zealand. Again, the Samoans had to adapt to a new colonial administration.

Nineteen of my interviewees grew up in Western Samoa and eleven grew up in American Samoa. Some of them are descendants of individuals who came to Samoa as planters and who were part of the DHPG. For example, the maternal grandparents of Amanda Galea'i Iuli were German-American planters and traders who married Samoans. Alice McElhiney (nee) Chadwick's father was a banker in the service of one of the commercial companies in Samoa. Isabella's father, Edmund Stehlin, was a partGerman Samoan in the employment of the New Zealand administration. The father of Sivao Hedwig Williams, who was also Sr. Makerita's maternal uncle, was a blacksmith and an overseer of the Tuanaimato plantation of the New Zealand Reparation Estate (NZRE), formerly the DHPG plantations. Born in 1919, Sivao's education ended abruptly when Mr. Eden (the Manager of the NZRE), turned up to her classroom at St Mary's convent school 'to look for the old man's daughter!' ${ }^{28}$ At 13, Sivao began a life of caring for others, working in domestic service, looking after Mr. Eden's children.

The different colonial administrations had a significant impact on social and political relationships at the turn of the century. The approaches of the colonial administrations towards Samoan traditional political and social institutions were characterised by

\footnotetext{
${ }^{26}$ Davidson, Samoa Mo Samoa, 77-9; Munro and Firth, "German Labour Policy and the Partition of the Western Pacific: The View From Samoa," 85-102.

27 Albert Wendt, "Guardians and Wards: A Study of the Origins, Causes, and the First Two Years of the Mau in Western Samoa." MA thesis, Victoria University of Wellington, 1965.

${ }^{28}$ Hedwig Sivao Williams, interview by Louise Mataia Milo, 4 Feburary 2015, Ponsonby, Auckland.
} 
paternalistic and Eurocentric attitudes. ${ }^{29}$ The German native policies, as Steinmetz has argued, were designed to 'transform indigenous ways of life' by changing indigenous society to fit into the colonisers' cultural and economic schemes. These colonial strategies disrupted Samoan political and social structures. The German officials interfered in the Samoan chiefly system by eliminating the use of paramount chiefly titles and demanding that Western Samoa recognise the German Kaiser as the only 'ali'i sili', paramount chief, and accept his representative's authority. Such a foreign policy disrupted the fundamental structure of the Samoan culture relations and created discontent. Traditional practices such as the malaga, that are manifestations of traditional social and political relations, were banned.

The New Zealand administration followed the German administration in its attempts to regulate the population. Campbell's comparative analysis of the New Zealand, US Navy and German colonial legacies in Samoa posited that the German administration was ruthless compared to the New Zealand administration when dealing with Samoan institutions. ${ }^{30}$ From an indigenous point-of-view, I argue that all the colonial administrations severely altered the Samoan way of life. From the beginning of the colonial era Samoans endured lesolosolou in colonial policies and attitudes that disadvantaged them. In most cases, those who had the most to lose were the most vociferous in their protests, but the entire population endured the misfortunes.

\section{Pandemic}

The military occupation of Western Samoa was a six-year disaster that severely affected Samoan cultural institutions. ${ }^{31}$ The tragic maladministration of the influenza epidemic, commonly referred as the 'Talune Incident', is a case in point. ${ }^{32}$ The epidemic killed approximately 22 percent of the Western Samoan population, weakening both the cultural and commercial economy. ${ }^{33}$ McLane's recent comparative study on the pandemic's effects in Western Polynesia show the severity of the epidemic in Samoa

\footnotetext{
29 Davidson, Samoa Mo Samoa, 80-9; Meleisea, The Making of Modern Samoa.

30 Campbell, "Resistance and Colonial Government: A Comparative Study of Samoa," 48.

31 William Neil Plimmer, "The Military Occupation of Western Samoa, 1914-1920" (Victoria University, 1966), 137

32 Wendt, "Guardians and Wards." 15-18

33 Sandra M. Tomkins, "The Influenza Epidemic of 1918-19 in Western Samoa," The Journal of Pacfic History 27, no. 2 (December, 1992),181
} 
compared to Fiji and Tonga. ${ }^{34}$ All the interviewees for this study had lost family members in the pandemic. Like Faanunumi's and Amanda's mothers, many of these interviewees grew up on the stories of the traumatic experiences involved. Amanda, born in 1927 in Manu'a, to a Samoan father and American-German Samoan mother, remembered how her mother had been traumatised because she lost most of her family in Safotu to the 'faama'i oti' - the death sickness. ${ }^{35}$

Faanunumi Tupa'i Taeao, born in 1921 at the village of Salani, recalled her mother's traumatic experience of the epidemic:

My mother survived the faama'i tele. She tells how she saw how some of the sick people died not directly from the disease but from the mole manava - starvation. There was no one to get food for the sick. Those people died also so there was no one to prepare any food. I think that was the year eighteen! ${ }^{36}$

The women in this study shared their parents' experiences of the tragedy. Fa'asalafa, as a young child was told that the church and the catechist's house by the church were also grave sites of villagers who perished in pandemic.

Our parents told us that during the pandemic, many people died at the church. So, both the church here (the Catholic Cathedral at Solosolo) and the Catechist's house next to it are all surrounded by graves. They said that during the fa'ama'i, the dead were buried close to the houses because the ones who buried you were also very sick. They just put you in the grave and bury you and that's it! No one could do the usual lagi, the Samoan burial rites. And if you died at home you were buried just outside the posts of the house. $^{37}$

The effects of the 1918 pandemic denied many Samoans the burial customs accorded by the Samoan culture. Families decreased in size and the family economy also suffered. As in the case of Faasalafa's family, people were not worried about prestige but more about ensuring that families survived the ordeal. The discontent with the loss of family

\footnotetext{
${ }^{34}$ John Ryan McLane, "Setting a Barricade against the East Wind: Western Polynesia and the 1918 Influenza Pandemic" (PhD thesis, University of Otago, 2012), 151-2.

35 Amanda Galea'i Iuli, interview by Louise Mataia-Milo, 26 November 2014, Leone, American Samoa.

${ }^{36}$ Faanunumi Rosa Tupai-Taeao, interview by Louise Mataia-Milo, Wednesday, 7 October 2017, Nu'usuatia, Upolu.

37
} 
members that affected family economy and cultural practices became one of the issues which led Samoans to protest against the New Zealand administration.

\section{The Mau Movements}

Dissatisfaction with many aspects of colonial rule in both territories led to protest movements against both the US and the NZ administrations in the 1920s and 1930s. The Samoan population criticised the racial and paternalistic attitudes of the colonial administrations in implementing social policies which affected Samoan cultural practices. Grievances stemmed from local chiefs' suspicion of the administration's handling of copra, meddling in Samoan chiefly affairs and other social issues which revealed the racial attitudes of the two administrations.

In US Samoa, the Navy's approach in dealing with expressions of discontent contrasted with the heavy-handed New Zealand approach in Western Samoa. Tensions mounted in the 1920s in the two territories against their administrators. In American Samoa the court of inquiry into Terhune's administration in 1920 resulted in a court-martial. Although it did not resolve Samoan issues, the fact that the navy attempted to attend to their complaints gave the chiefs some satisfaction. ${ }^{38}$

Most Samoans remember that the Americans at times listened to some of the Samoan chiefs who opposed some of their policies and embraced their participation through regular meetings of the district representatives. In Western Samoa, the protests against the administration resulted, in December 1929, in the Black Saturday killings of Samoans such as one of the Samoan leaders, Tupua Tamasese Lealofi III. Also, killed in this incident, yet rarely acknowledged, were Migao, Leota, Enesi, Tapu, Ainoa, Faumuina of Savai'i, Vele and Tu'ia. ${ }^{39}$

Faanunumi remembered vividly the time when the Mau supporters marched through the villages, gathering support for the cause.

When we were kids we used to see people march through our village (Salani). We were always scared of it. O le tagavai a Sapunaoa a alu e sa se isi ona toe maua i le auala. When the Sapunaoa village march with their

${ }^{38}$ Kennedy, The Tropical Frontier, 125-48

${ }^{39}$ Michael J. Field, Mau: Samoa's struggle against New Zealand oppression. (A.H. \& A.W. Reed Ltd., 1984), 1567. 
banners, no one is allowed on the road. Because they carried axes and machetes. They take down everything in their path. They were also singing songs in support of Tamasese. I learned afterwards that they were all Mau supporters with their blue ie. ${ }^{40}$

Here the Samoan custom of waging war was used as a way of expressing their discontent against the colonial administration. The Sapunaoa banners in support of the Mau were paraded through the villages in the form of a war party moving through the villages. These marches became a common scene throughout the villages in the 1920s and 1930s.

The political struggle to deal with the colonial administrations' Eurocentric policies meant that women, as members of society, were also struggling. The Mau members took to the hills after the New Zealand administration declared it to be seditious in 1930. Women and children were often left vulnerable and demoralised in their own homes because of the raids by the New Zealand police together with the incarceration and deportation of the Mau leaders and their supporters. When Faasalafa was young she saw how the arrival of troops caused a lot of commotion in her village.

I was young when I saw them. I remember when the vaega au came it caused a lot of action here. If it was daylight the men would run away to the bush close by. When they come at night, some of them would climb up the roof of the houses and hid there. They come in the night sometimes and beam their lights towards the houses but found only the women and children sleeping. And when they found a Mau uniform, they take the blue uniform and tear off the white mua and toss it. I was still young then but I saw that is what they did. ${ }^{41}$

At the same time, however the 'Samoa Women's Mau' emerged to provide leadership. At the helm of this group were the wives and sisters of the leaders of the Mau. Truly the Mau became a family, a Samoan affair. Out in the villages, women played a crucial role helping the Mau supporters avoid being caught by the troops.

The kids composed a song about a woman named Faaofo from our village, who used to ring the bell to signal to the men of the village that the troops were approaching. Ta loa le logo, Faaofo ua oso, Oso ia Tuvale aua le ofu o

40 Tupai-Taeao, interview.

${ }^{41}$ F. Leota, interview. 
le misionale. Papalagi ua omai, e fai i ai o oe o le fai lotu, ua le kea i latou ae ua fesili poo fea le faifeau ae tali o loo i Apia. ${ }^{42}$

Others like Nanati were close to the epicentre of political protest in the 1930s in American Samoa. Nanati's grandmother was involved in the 1920s Mau movement against the US Navy administration. Nu'u'uli, where Nanati lives, was the headquarters for both the 'Mauga's Mau' and the Nu'u'uli - Manu'a Mau. ${ }^{43}$ The chiefs and other supporters criticised the Navy for maladministration of copra funds, attempts to ban marriage between naval officers and Samoan women and interference in traditional Samoan titular matters such as the appointment of the Tuimanu'a.

Nanati's family was at the centre of these political protests in Nu'u'uli. The Mau fale fono (meeting house) built by supporters from all over the Samoa islands during the protests was situated on her family's land. Nanati related that the house came down after cyclone Ofa in $1990 .{ }^{44}$ Her family's political activism meant that Nanati grew up in a political environment and was aware of the political issues that were significant to the women in her village and around American Samoa as well in the 1920s and 1930s. She remembers vividly how her family engaged with village affairs: 'E potopoto i le matou fale talimalo. E mautu foi le tinifu. The Samoan way of life was already embedded in this village before the marines arrived. They (the village groups) often congregate at our big house. The tinifu were very active as well. ${ }^{45}$

Samoan historiography has rightly placed considerable emphasis on the disastrous management of the pandemic and the other heavy-handed policies of the New Zealand administration which led to political protest in Western Samoa. ${ }^{46} \mathrm{It}$ is important, however, not to overlook the ways in which developments in areas such as education and health care were also shaping the lives of Samoans during this era as well as some of the other forms that colonial control took.

\footnotetext{
${ }^{42}$ F. Leota, interview.

43 David A Chappell, "The Forgotten Mau: Anti-Navy Protest in American Samoa, 1920 -1935" Pacific Historical Review, 1 May 2000, Vol.69 (2), 235-7.

44 Chappell, "The Forgotten Mau", 251; Savusa, interview.

${ }^{45}$ Savusa, interview. Tinifu - another name used to refer to the Aualuma.

46 Campbell, "Resistance and Colonial Government: A Comparative Study of Samoa," 46.
} 


\section{Welfare and Health}

Primary health care programmes brought to the villages modern medical care that greatly improved population growth. Health departments were set up in both territories as well as nursing schools. Motivated by the disastrous pandemic, the New Zealand administration's commitment to primary health care improved the lives of the women born before the war. ${ }^{47}$ The sanitation programmes led to the establishment of the village women's sanitation committees, commonly known as komiti tumama, all over Western Samoa. Rural health care improved hygiene and people's health as seen in efforts to eradicate yaws in the late $1920 \mathrm{~s} .{ }^{48}$ However, Campbell's assessment points out that welfare and development policies were characteristically a means to an end to establish political control. ${ }^{49}$

The teaching of basic hygiene and health care which had been introduced by the missions was brought under government structures. The administration collaborated with the LMS missionaries to improve basic health in the villages, which led to the production of healthcare instructions for Samoan medical practitioners, nurses and women's health committees. The health books were written in both the English and Samoan languages. The third volume in this health series provided instructions about baby welfare and women's committees for village mothers. ${ }^{50}$ In 1934, the LMS opened the Papauta Baby Clinic at the Papauta Girls School and training schools for nursing for the welfare of babies began in 1935. Nurses, played a very important role in driving healthcare in the villages. The Administration set up a nursing school at Motootua to care for Samoan patients (Figure 6 and Figure 7). One of the challenges the administration faced in Western Samoa, however, was the loss of well-trained young nurses to marriages. Monaghan, the Acting Chief Medical officer, expressed this concern in his correspondence with a Mr. Stallan:

It is rather hard on the department when just when their training is finished, and their services are badly needed, that we should lose them so soon. We receive no benefit from all the time put in coaching and teaching them. If

\footnotetext{
47 Penelope Schoeffel, "Gender, Status and Power in Samoa," Canberra Anthropology 1, no. 2 (1978), 210.

48 Penelope Schoeffel "Dilemmas of Modernisation in Primary Health Care in Western Samoa," Social Science \& Medicine 19, no. 3 (1984), 210.

${ }^{49}$ Campbell, "Resistance and Colonial Government: A Comparative Study of Samoa," 57.

${ }^{50}$ E. A. Downs and Dr. H. B. Turbott, Health for Samoa [Maloloina mo Samoa] (Wellington, N.Z.: Govt. Printer, 1937).
} 
they are useful to you as regards their medical knowledge, could you not use your influence in regards to them marrying your missionaries, so we could have their services for two years after they have been trained? ${ }^{51}$

American Samoa had a similar problem with their nurses and according the chiefs, 'many nurses marry soon after graduation, and thus few single nurses are available for assignments. ${ }^{52}$ The nurses who married and moved away from the nursing school applied their knowledge in their own communities where they were also members of the church, the aualuma and the newly formed women's health committees. So, in a way, the hospital's loss, as highlighted by the health officers' concerns, was the community's gain when the young married nurses brought their new knowledge to the villages.

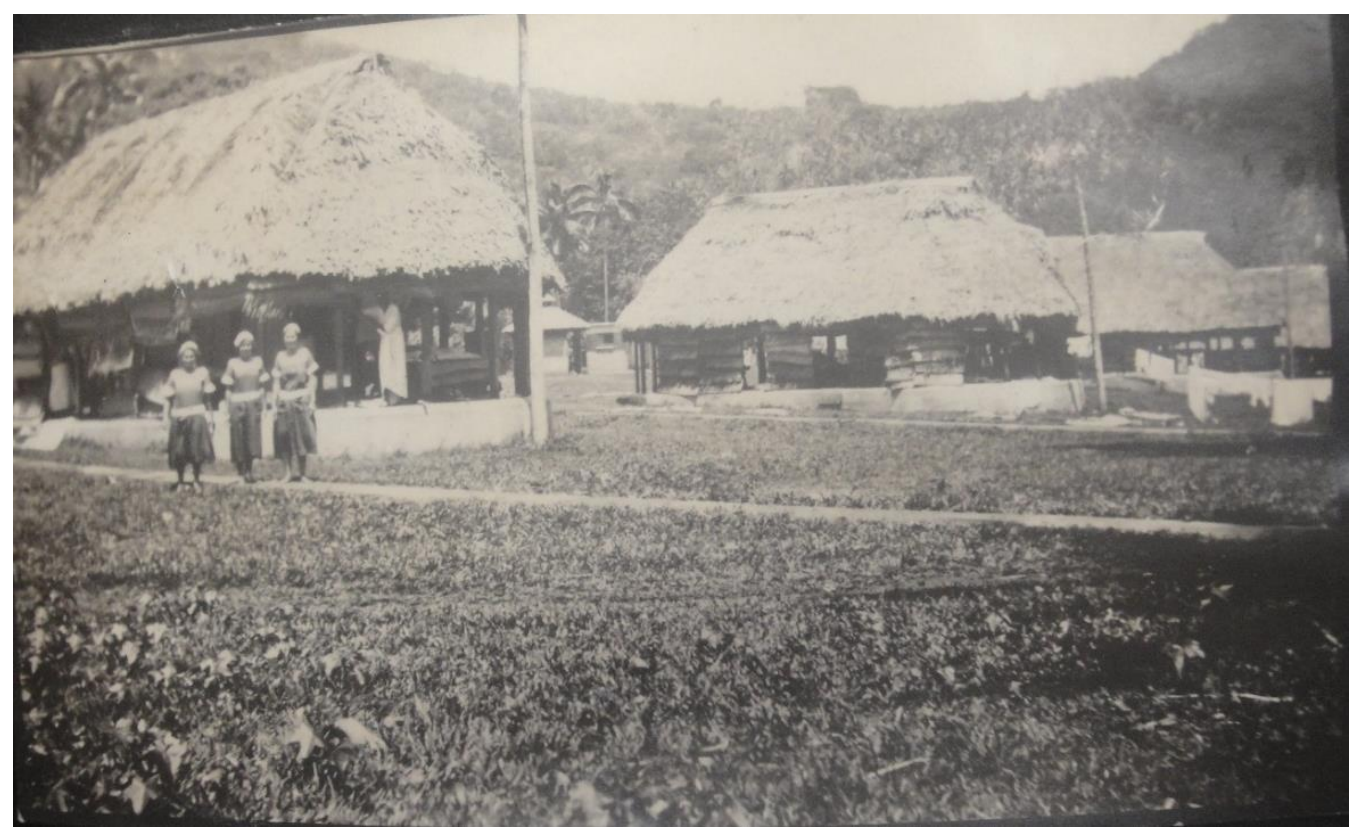

Figure 6 Samoan Hospital, Motootua circa early 1940s. (Source: Mary Lambie album)

51 Monaghan (Acting Chief Medical Officer) to Stallan, 18 May 1937, LMS - Samoan District Correspondence with the NZ Administration, 1915-46, MS Roll 08, PMB 0144, Alexander Turnbull Library, Wellington (hereafter ATL).

52 Public Health Officer to Manu'a District Resolution, 1935. Records of the Government of American Samoa, T-1182 ROLL 19, National Archives and Records Administration, San Bruno (hereafter NARA). 


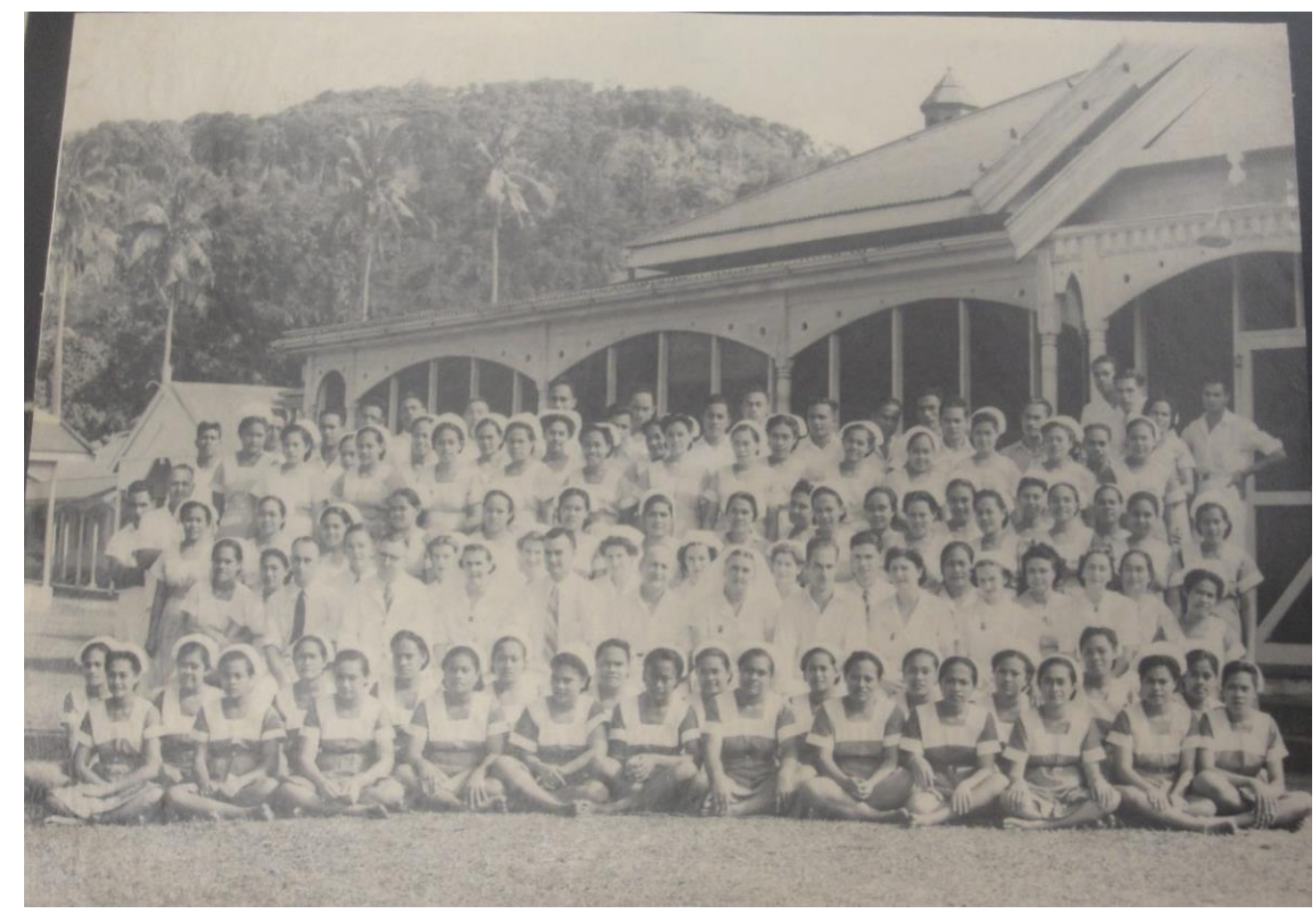

Figure 7 Nursing School, Motootua, 1943. The hospital for Europeans is in the background. (Source: Mary Lambie album.)

In American Samoa, initiatives struggled to gain funding due to the reluctance by the metropole to finance the Navy's welfare and development policies. The health care system for the Samoans was one of these projects that had a plan but no funding. A Samoan hospital was built and the navy supplied the medical personnel, but Samoans had to pay to for the medical care provided. The Navy Hospital and Dispensary was exclusively for the Navy personnel.

The Samoan hospital required Samoan health care personnel, however, and the navy looked towards the Atauloma School for girls to fulfil this role. ${ }^{53}$ In 1913 the Samoa Nurses' training school was set up and the first graduates of this training program completed their studies in 1916. The wives of missionaries in Tutuila recommended Samoan women to the US nursing personnel responsible for the training; their advice was to choose women who had passed child bearing age. ${ }^{54}$ This recommendation may have reflected an assumption that young Christian women raised at the village pastor's

53 Amerika Samoa Humanities Council, A History of American Samoa, 183-5.

54 H. M, "Samoa," The American Journal of Nursing 14, no. 12 (1914), 1069-73. 
house had little maternal health experience. It may also have reflected awareness of the differences between European and Samoan attitudes towards the body. The concept of 'va tapuia' prescribes that men's and women's bodies must not be seen or exposed in the presence of the other. The men looked after the men and the women did the same. More generally, however, the recommendation illustrates one of the ways in which women's lives and the opportunities available to them were shaped by the missions.

\section{Education - Schools}

The churches were the principal providers of formal education in Samoa in the 1920s and 1930s together with the colonial administrations who were already attempting to improve the level of education. The village schools, run by the Pastors and Catechists were the key social instruments, which shaped and sustained the churches' influence over the Samoans. Their main aim was to reinforce the denominational beliefs and canons with little or no emphasis on Samoan culture.

Formal education as offered by the missionaries and the administrations was mainly concerned with skills and western values and behaviour seen as desirable by the missionaries and the administrations. Before 1930, the Navy pursued an education policy to 'make Samoa an English-speaking Colony. ${ }^{.55}$ Government funds sustained the growth of schools and the training of teachers, but these schools were gradually becoming institutions that the chiefs had no control over and were beginning to threaten Samoan values and behaviour. The chiefs expressed their dissatisfaction with the school system that did not teach their young people to respect the ancient Samoan customs, especially the language. Tufele of the Manu'a district commented, 'the children should learn their own language and the customs of their people, like they do in all other nation, like they do in America and in Germany. The Germans do not first try to learn the English language; they learn their own language first. The Samoa children should know their own language and customs. ${ }^{56}$ In 1933, the education policy changed to 'make them increasingly conscious and proud of their own Samoan heritage of arts, crafts, customs and culture in the hope that these may not disintegrate under the

55 Pedro Cruz Sanchez, "Education in American Samoa" (Educat.D., Stanford University, 1956), 131-5. ${ }^{56}$ Tufele, Manu'a District, Fono Records, 1929. Records of the Government of American Samoa, T-1182 ROLL 18, NARA. 
influence of increasing contact with the world beyond. ${ }^{57}$ The reformed policy continued in the post-war years.

Western Samoans' experience of education was different from in American Samoa. The NZ administration was not in a financial position in the 1920s and 1930s to set up a secular and compulsory education system. Efforts to develop a centralised school system in Western Samoa did not eventuate until after the war. However, the administration was developing a general education scheme that linked the village schools run by the missions to the administration schools. ${ }^{58}$

The NZ administration structured the education system in 1933 in two levels. Grade I schools consisted of the Mission schools which took in pupils between the ages of 3 and 30 years. The curriculum was basic reading and writing and domestic skills. The curriculum was left to the discretion of the missions. Most of the schools available for girls were residential or boarding schools. For girls in general, attending school took them away from their homes and villages. Ana, Alice, Saini, Isapela and Tauvaga shared this experience of leaving their families to be educated together with other girls either at the Convent school at Moamoa, Atauloma or at Papauta. According to the administration, the boarding schools prepared girls for a higher standard of village life as it was very common that Samoan women married young after leaving school. On the other hand, there were also the day pupils in populated areas such as Apia and Leauvaa. These schools met the needs of pupils who would pursue their education further.

Music, sewing, typewriting and shorthand were part of the special curriculum taught in some schools. ${ }^{59}$

The Missions collaborated with the NZ administration to provide for Grade II schools as a progression from the village schools. In this structure the administration funded and regulated the training, supervision, and payment of the teachers while the Missions in the villages provided the schoolhouses. Very little English was taught at the village schools before the 1940s. In 1933, a total of 39 Grade II schools existed in Western

57 Sanchez, "Education in American Samoa," 87.

58 Campbell, "Resistance and Colonial Government: A Comparative Study of Samoa," 52.

${ }^{59}$ New Zealand Administration of Samoa, " Eighth Report of the Government of New Zealand on the Administration of the Mandated Territory of Western Samoa for the Year Ended the 31st March, 1933," (Wellington: New Zealand Government, 1933), 13-4. 
Samoa, staffed by Samoan men who had received training. Existing alongside the mission schools in the 1930s were other schools, fully funded and operated by the administration. These included, Avele School, set up as an agricultural school, Vaipouli in Savai'i, the training school, and Intermediate school at Malifa and the Ifi Ifi School for Europeans. ${ }^{60}$

Unlike the American Samoa school system, the schools in Western Samoa reflected the racialised aspects of colonial Samoa. The cousins Sivao Williams and Makerita Leauna'i remembered how the Convent school they attended at Savalalo was segregated into two schools; St Mary's was for European and part-Samoan/Chinese girls and the daughters of prominent paramount chiefs, while St Anne's was for Samoan girls, 'e leai ni fa'ai'u palagi! - no foreign surnames'. This set up did not go unnoticed but was seldom talked about at the time. Reflecting on these times, Sivao commented that 'E faailoga lanu i levaega e leai ni faa'iu palagi - They were racist against those who did not have foreign last names. ${ }^{61}$ The schools at Ifi'ifi and Malifa, at the government compound, also had the same limitation that carried through in the 1920s and 1930s.

The Marist sisters were atuned to the changes in girls' education outside of Samoa and introduced subjects that would have a profound effect on the trajectory of Samoan women's employment after the war. In 1925 St Mary's School at Savalalo added commercial training to its curriculum, including subjects like typing, commercial English, commercial practice, book keeping and shorthand (stenography). ${ }^{62}$ Alice attended a school that offered these subjects. Sivao who was already working as a baby sitter and a housemaid by 1939 recalled how she helped her parents support her youngest sister, Lydia, who received a more modern education so she could have a career. The nuns who introduced and successfully sustained this bold program were Americans with backgrounds in commercial and secretarial studies and a different outlook from the European missionaries. The new courses signalled a change in the attitude towards girls' education that envisioned young Samoan women leading

\footnotetext{
${ }^{60}$ New Zealand Administration of Samoa, "Mandated Territory of Western Samoa (Eighth Report of the Government of New Zealand on the Administration of) for the Year Ended the 31st March, 1933," (Wellington: New Zealand Government, 1933), 13-4.

${ }^{61}$ Williams, interview.

${ }^{62}$ Emma Kruse Vaai, "Sister Patrick's Golden Girls," in Tamaitai Samoa: Their Stories, ed. Peggy FairbairnDunlop (Suva: Institute of Pacific Studies, USP, 1996), 161.
} 
successful careers in the workforce and sharing workspaces with men in contrast to the earlier rationale for women's education as a preparation for a life in the village in domestic roles. Many of the former Savalalo students later migrated to New Zealand and found their secretarial training very useful.

\section{Controlling Miscegenation and Marriage}

One of the issues that preoccupied all colonial administrations in Samoa before the Second World War was keeping the populations segregated by introducing laws that prohibited marriages between foreigners and Samoan women. Miscegenation was common and had created a significant part-European/part-Samoan population by the 1930s. In most cases, European-Samoan unions were formalised. Marriage in the Samoan sense was viewed to access resources, cultural capital, and networks and in many instances it was a chance for one of the families to ascend the social hierarchy. However, the increase of unions between Samoan women and foreigners was viewed as threatening colonial rule because they blurred the boundaries of authority drawn on racial lines. ${ }^{63}$

All three colonial administrations sought to regulate race mixing and Samoan customs to maintain control. The German administration forbade marriages between Germans and Samoans in 1912. ${ }^{64}$ Marriage proposals had to be signed off by the 'Kaisalika', the German governor. The governor also passed laws that categorised indigenous Samoans as separate from 'part-Europeans' and published the registrations of these part-Samoan families in the local newspapers. ${ }^{65}$ Shankman notes that the German administration's aim was to 'protect the Samoans from lower class Europeans' who frequented Samoa. ${ }^{66}$ The NZ administration inherited these developments and it too discouraged colonial officials from having relationships with local women. Both the German and NZ administrations also sought to discourage relations between Samoans and the indentured Chinese and Melanesian labourers due to the fear that the Samoan race

\footnotetext{
${ }^{63}$ Meleisea, The Making of Modern Samoa, 60-62.

${ }^{64}$ George Steinmetz, The Devil's Handwriting; The Fiji Times, Tuesday 10 February 1912, AGCA 6051 ROLL 81, ANZ.

${ }^{65}$ Lolepa Schmidtz - Consent letter to German Governor for the marriage of Theresa to J. Johnston 28 October 1896, German Samoa Archives AGCA 6051 File 1092, ANZ.

66 Paul Shankman, "Interethnic Unions and the Regulations of Sex in Colonial Samoa, 1830-1945." The Polynesian Society 110, no. 2 (2001): 126-7.
} 
would be mongrelised by the Chinese or become inferior by any union with the Melanesian labourers. ${ }^{67}$

In American Samoa the Navy was also 'notorious for its domestic colour bar'. ${ }^{68}$ The Navy banned any interethnic unions in 1919 to prevent Samoans suffering from the fate of the Hawaiians' and becoming landless in their own society. ${ }^{69}$ Nevertheless sexual relations between naval officials and American Samoan women led to a gradual increase in the number of illegitimate children. The naval officials' reluctance to fulfil paternal responsibilities became one of the reasons for Mauga's Mau in the 1920s. ${ }^{70}$

Despite all efforts by colonial officials, sexual relations still occurred whether approved or not. These unions transformed the Samoan social landscape as the offspring could potentially access multiple social networks. Children born out of wedlock were generally raised by Samoan families. Children from unions recognised as legal by the colonial officials were registered as part-Samoan. By the 1920s, the part-European Samoans whom the colonial administrations had expended so much energy, time and money to control were becoming more visible in public life. Many of them had been educated outside of Samoa but they sympathised with their Samoan families, as was the case with the famous businessperson, Olaf Nelson, who opposed New Zealand's colonial policies, and the hotelier Aggie Grey, to name just two examples. ${ }^{71}$ These "troublesome half castes" began to make their presence felt in Samoan politics and social life in the 1920s and 1930s. They were troublesome because they did not fit into the rigid colonial moulds and had great interests in the development of Samoan affairs.

The part-Chinese and part-Melanesian population was largely confined to the plantations and in the remote villages. They did not have the freedom of movement and access to social capital enjoyed by the part-European Samoans. Some family histories

${ }^{67}$ Liua'ana, Samoa Tula'i; Paul Shankman, "South Seas Confidential: The Politics of Interethnic Relationships in Colonial Samoa," in Globalization and Culture Change in the Pacific Islands, ed. Victoria S. Lockwood (Upper Saddle River, N.J.: Pearson Education, 2004).

${ }^{68}$ Campbell, "Resistance and Colonial Government: A Comparative Study of Samoa," 51.

${ }^{69}$ Kennedy, The Tropical Frontier, 46; Mataia-Milo, "There Are No Commoners in Samoa".

70 Chappell, "The Forgotten Mau," 235.

${ }^{71}$ Olaf Frederick Nelson, Misleading the Commission - Samoa at Geneva: Misleading the League of Nations : A Commentary on the Proceedings of the Permanent Mandates Commission at Its Thirteenth Session Held at Geneva in June, 1928 (1928); Fay Alailima, Aggie Grey: A Samoan Saga (Honolulu: Mutual Publishing Company, 1988); Damon Salesa, "Emma and Phebe: 'Weavers of the Border'," Journal of the Polynesian Society 123, no. 2 (2014), 145-67. 
reveal the invasive and humiliating way the colonial officials ransacked Samoan houses to find Chinese or Melanesian labourers suspected of having relationships with Samoan women. Nonu Masae Atogi, a Samoan-Chinese who grew up in Safotu, confirmed these experiences. ${ }^{72}$ Liua'ana discusses in detail the ill treatment of the Chinese by the New Zealand administration in the 1920s and 1930s and the unsuccessful policing of these relationships. ${ }^{73}$

Colonial ideas and policies that sought to devide the Western Samoan population along racial lines were manifested in the segregated schools and in the two hospitals for Europeans and Samoans as well. Five of the interviewees are mixed blooded Samoans, yet all of them had different upbringings, depending on their geographic location and their parents' social standing. None of them grew up as Europeans. Some lived like Europeans and moved within European and New Zealand administration circles, others identified and lived as Samoans in the villages. Isabella and Tuala were both daughters of Samoan born half-caste men who were New Zealand administration officials. Amanda, an American/German Samoan grew up in the Catholic Church, under the watchful eye of Sr. Mathew, a European nun. Alice stayed at the convent most of her young life.

\section{Censoring entertainment.}

The colonial authority used a variety of policies to hold on to political power and continue to police sectors of the population that challenged their authority, such as the half-caste population and the chiefs. Other less visible policies also had far-reaching consequences for the women who grew up before the war in terms of their exposure to cultural influences from outside Samoa. Censorship of popular cultural activities and entertainment reveals the less visible ways in which colonial control steeped into the mundane and taken for granted aspects of life.

The censorship of motion pictures by the NZ authorities was carefully conducted to sift out ideas that might stimulate an uprising against the administration. This subtle policy

\footnotetext{
72 Nonu Masae Atogi, interview by Louise Mataia-Milo, 16 October 2014, Paia, Savai'i.

${ }^{73}$ Ben Featuna'i Liua'ana, "Dragons in Little Paradise: Chinese (Mis-) Fortunes in Samoa, 1900-1950," The Journal of Pacific History 32, no. 1 (1997), 29-48.
} 
reveals the anxieties of colonial officials in dealing with an indigenous population that was becoming conscious of its own ability to recapture its autonomy.

Colonial officials took great care in deciding which movies the general population in Apia could watch through a thorough censoring process in Wellington. In 1929 a letter from the NZ based censor, W.A. Tanner, to the under-secretary of the Department of Internal Affairs, observed that 'what would be ordinary fare for an educated population like New Zealand would probably be very questionable fare for a primitive people like the Samoans. ${ }^{74}$ Tanner went on to say:

One of the principal concerns in Samoa is to see that the white race is not brought into contempt by the exhibition of films which would tend to lessen the respect of the natives for the white man, which is so essential. From motives of safety this is necessary in a territory where the natives heavily outnumber the whites. Even a picture with the famous dog Rin Tin Tin would be questionable as the dog frequently fights and overcomes the villain - a white man. ${ }^{75}$

On the surface, Rin Tin Tin is a great entertainment. But at the level of social relations, Rin Tin Tin is about contestation of power. Tanner feared that to expose the Samoans to such 'entertainment' would incite an uprising. Knowing this colonial anxiety implies that the movies allowed in Samoa during such a politically dramatic time focused on the images that would have raised good character and reputation of the coloniser.

The female body was also a colonial concern. Tanner sought the opinion of the Film Censor of the British administration in Fiji instead of asking the view of the Samoans. The Fiji censor, Baylay, explained his own personal judgement of what was and was not suitable for the Samoan audience:

For the natives, there are two things I must be very sure and not show: nude women and bedroom scenes where women are not dressed and where any black man is getting the best of a white man in any fight or boxing match. I could not show Jack Johnson beating any white man but could show all pictures where the white man puts Jack Johnson down.

The police are very good to me, they take my word very often that the programmes are free of these scenes without me always going through

\footnotetext{
${ }^{74}$ Memorandum from W.A. Tanner (Censor) to the Undersecretary, Department of Internal Affairs, 31 October, 1929, R17964154, Censorship of Films for Western Samoa - 1920-1936, ANZ.

${ }^{75}$ Memorandum from W.A. Tanner (Censor) to the Undersecretary, Department of Internal Affairs, 31 October, 1929, R17964154, Censorship of Films for Western Samoa - 1920-1936, ANZ.
} 
them. On my part I am most careful when going through your synopses. If [the police] say it should not be shown I return to you, not shown knowing you will give me one in place of it. Nearly every night some of the police are in the pictures. All films shown in Fiji can be safely shown in Samoa. ${ }^{76}$

The women in this research were already consuming popular cultural material filtered through a colonial racial prism to which they were oblivious. Some of the women interviewed lived close to the cinemas and could afford to go to the movies or the concerts at the Tivoli. For example, Palepa Sooalo of Safotu saw a few western films when she was young at the village shop owned by a half caste family. ${ }^{77}$

In American Samoa, the naval administration had access to the movies within the naval compound, away from the local people. However, when the Fono was in session, movies were a common feature of the entertainment program. The chiefs attending the fono, together with their wives, would be be invited to an open screening of a movie that the governor would choose, which were mainly westerns. ${ }^{78}$

\section{The view from the village}

I have charted the general scene and how the two administrations effected social control throughout Samoa by exploring the social and political forces that influenced women's lives. The discussion in the next section focuses more on the institutions shaping their lives in the village. Exploring this important part of the Samoan women's lives is fundamental to understanding Samoan women's behaviour and its intimate connection and place in the Samoan culture on the ever of the Second World War. At the heart of this discussion are the concepts of the feagaiga/the covenant, the aualuma, and the taupou, which are all concepts that determined Samoan women's roles and the spaces they occupied in Samoan society's social structure. As observed by the anthropologists who visited Samoa of the 1930s, the social structure was undergoing major changes, which also meant that elements such as the aualuma were reconfigured.

\footnotetext{
${ }^{76}$ Letter from J. Baylay, Suva, Fiji to New Zealand Picture Supplies Ltd., Wellington, 4 September 1920, R17964154, Censorship of Films for Western Samoa - 1920-1936, ANZ.

77 Sooalo, interview.

78 Aides Notes on the Annual fono, 3 November 1939. T-1182 ROLL 19, Records of the Government of American Samoa, NARA.
} 


\section{Reconfiguring the Aualuma}

Almost all the interviewees and their mothers were involved in some way with their village aualuma, also known also as the nu'u o tamaita'i (the assembly of women) and in American Samoa as 'tinifu'. ${ }^{79}$ The aualuma consists of all the daughters of the chiefs (paramount, orator and lesser chiefs) in a village. It is the usual practice that married women would move to their husband's village. When they become widowed they return to their families and take their place again with the aualuma. This is the Samoan woman's institution for socialisation. All Samoan women belong to a chiefly title so no one is left out. It is within this group that all the daughters and sisters of the chiefs congregate. Women who marry into the village come under a different group known as the Faletua ma tausi, ma ava a taulele'a - the wives of the chiefs and orators. ${ }^{80}$ Traditionally the aualama's wide-ranging executive roles give it a lot more political power than the faletua.

All Samoan villages have honorifics specific to their aualuma. As a body politic, it duplicates the Samoan chiefly system; every member of the aualuma occupies a space which corresponds to her family chief's location in the council of chiefs. The aualuma, literally translates as 'the ones at the front', signifies the importance of women as the exemplified feagaiga or covenant and the space they occupy in the Samoan body politic.

The aualuma has a wide variety of functions. In addition to its spiritual roles, it is the place where Samoan women learn their place in society and skills such as weaving the different types of mats used in cultural activities and are instructed in etiquette. As described by Faasala, learning in the aualuma involved observing the older girls and women: 'o amio lava a teine matutua na matou faataitai i ai - we copied what the older girls were doing. ${ }^{, 81}$ It is also the place where they might talk about private bodily knowledge and sex. This type of knowledge according to most of the participants was usually transmitted via euphemism or in songs or in specific cultural occasions that had a sexual end, such as hosting a aumoega, a travelling party in pursuit of a marriage proposal to a village taupou, a woman of rank. Both Tiresa Fiti Brown of Vatia and

\footnotetext{
${ }^{79}$ Tinifu is mostly used in Tutuila and Manu'a. In Upolu and Savai'i tinifu refers to young children. ${ }^{80}$ Faletua ma tausi ma ava a taulelea - the group of wives Faletua (paramount chiefs' wives) and tausi (orator chiefs' wives) and ava a taulele'a (wives of untitled men).

${ }^{81}$ F. Leota, interview.
} 
Faasalafa from Solosolo experienced hosting aumoega travelling parties who visited their respective villages. The aumoega is a form of traditional courtship in which a party of men, often led by a chief or a manaia (son of a chief), accompanied by a known orator and untitled men seek a marriage proposal from the taupou of the hosting village. $^{82}$

The aualuma was also a network in which all the village women would consult each other and share problems and find solutions to challenges they faced either at the village level or within familes. For Faanunumi, the aualuma was important as a place where problems could be shared and solutions found: 'O le aualuma e aoga e faasoa atu ai se mea o ota vaivai ai ae e fesoasoani mai ai foi isi tamaitai. The aualuma is useful to me because I get to share things that I am weak at while others come and help. ${ }^{93}$ It is in this sharing network that women become closely connected with each other and learn from each other's successes or failures.

Within the aualama exists the institution of the taupou or augafa'apae, an unmarried lady of rank. She is the ceremonial head of the aualuma under the patronage of the senior aualuma women. An elected unmarried lady from a paramount chiefly line is bestowed a taupou title firstly in the presence of the chiefs and then at a place designated by the aualuma. In some villages taupou are acknowledged and respected by the chiefs because they are the chiefs' representatives in the women's group. A village may have one or more taupou depending on the number of paramount chiefs and the political structure of the village. There is normally one aualuma that hosts the taupou, but there are variances in cultural practice across the archipelago. Ana Peletisala and Faasalafa Leota of Solosolo noted that in their village in the 1930s there were two aualuma associated with two separate taupou from two different chiefly families. ${ }^{84}$

The taupou is the embodiment of the aualuma's political influence. The aualama is responsible for grooming the taupou in their roles as dignified leaders and in the etiquette of the ritualised roles they are expected to perform especially the task of hosting guests in a manner that upholds the honour and dignity of the chiefly title,

\footnotetext{
82 Penelope Schoeffel Meleisea, "Daughters of Sina", 172-73; Fairbairn-Dunlop, Tamaitai Samoa, 4-19.

${ }^{83}$ Faanunumi Tupai-Taeao, interview by Louise Mataia-Milo, Wednesday, 7 October 2014, Nu'usuatia, Upolu.

${ }^{84}$ Savea, Interview; F. Leota, Interview.
} 
family, and village that the taupou represents. A taupou's power and honour peaks when she is married and moves to her husband's village where she joins the faletua ma tausi ma 'ava a taulele'a. ${ }^{85}$ Another unmarried young woman is then selected to take her place. A taupou's marriage rituals in polygamous Samoa included the fa'amaseiau, the ceremonious public deflowering, also known as a virgin ceremony, of a woman of rank. This challenged Christian beliefs and practices and was one of the first Samoan social practices banned by the missionaries. ${ }^{86}$

Several of the women interviewed for this study were taupou or sisters of taupou. Tuala was bestowed the taupou title, Falenaoti, after she returned from her studies in New Zealand in the late 1950s. She was respected by her village aualuma. At her wedding in 1963 she did not go through a virgin ceremony. Faasalafa was the closest friend and sister of the Taupou, Tuitogamatoe Alauni. She seldom left her sister's side until she got married. Nanati was given the taupou name for the Savusa chief at birth. These three examples indicate the variations of etiquette and practices that surrounded the lives of taupou women that scholars observed in the decade leading up to the war.

Various scholars have mapped out the changes in the aualuma and the taupou from the 1830s to the 1930s as a result of evangelization and other developments in Samoan history. The missionaries in their drive to proselytise Samoa stimulated the transformation of Samoan institutions such as the aualuma and created a sequence of changes that contributed to its fragmentation. The aualuma's influence on young women's social orientation was of concern to the Christian missionaries who sought out strategies to transform it and to bring Samoan women's cultural practices in to line with their newfound Christian faith.

\footnotetext{
85 The taupou system continues to evolve. In the 1960s and 1970s a holder of a taupou title retained her designation even after she was married. Recently, a grandmother was bestowed a taupou title from a village in the Anoama'a district.

86 Athough Rev. John Williams of the London Missionary Society banned this aspect of the elite marriage ritual the 1830s, the practice continued even in the early 1930s. Richard M. Moyle, ed. The Samoan Journals of John Williams, 1830 and 1832, Pacific History Series No.11 (Canberra: Australian National University Press, 1984). See Lynne Enari, "Fuatino Koke Aiono," in Tamaitai Samoa: Their Stories, edited by Peggy Fairbairn-Dunlop. (Suva: Institute of Pacific Studies, 1996). 72-4.
} 
The anthropologist Patrick A. Buxton highlighted how the missionaries and the colonial administration policies interfered with Samoa's social structure. ${ }^{87}$ Buxton saw the taupou in 1928 as a 'pawn in local politics', especially in regards to the ritualiszed traditions that emphasised modesty and polygamous marriage to paramount chiefs for begetting high ranking children so as to strengthen the father's political power, a practice which connotes the significance of pedigree in Samoan society. ${ }^{88}$ In 1928 Margaret Mead intrigued the academy with her claims that the Samoan young women experimenting with sex was evidence of a relaxed transition into adulthood. ${ }^{89}$

Keesing two years later shared Buxton's view, highlighting missionary activities as the main cause of the decline of Samoan polities, including the aualuma and the taupou. ${ }^{90}$ Assessing the transformation of the 'taupou' institution, Keesing observed that the changes were a direct effect of the vacuums created in the women's institutions when the missionaries banned some of the cultural practices that had core cultural functions. ${ }^{91}$ Keesing was referring to the missionaries' attempts to Christianise Samoan women's traditional institutions by influencing marriage practices from polygamous to monogamous unions. The missionaries also tried to reconfigure traditional Samoan women's agency by setting up groups such as the Christian women's fellowship as alternatives to the traditional agencies of the aualuma, who sustained the cultural practices of their figure head. Keesing's and Mead's work is significant because it informed US officials' understandings and perceptions of Samoan women when the allies arrived in Samoa in 1942.

The Christian alternative institutions that replaced indigenous cultural institutions altered Samoan women's agency. Some of the Samoan customs that are linked to the institutions of the aualuma and taupou were seen by the missionaries as immoral. These included aspects of marriage rituals, hosting the aumoega, polygamy and other practices that linked the aualuma and taupou to the overall structure of the fa'asamoa. The

87 Patrick A Buxton, Researches in Polynesia and Melanesia: An Account of Investigations in Samoa, Tonga, the Ellice Group, and the New Hebrides, in 1924, 1925 (London: London School of Hygiene and Tropical Medicine, 1927); P. A. Buxton, Brown Men and White in Samoa: Researches in Polynesia (London: London School of Tropical Medicine, 1928).

88 Buxton, "Brown Men and White in Samoa", 103.

${ }^{89}$ Mead, Coming of Age in Samoa (New York: William Morrow, 1928).

${ }^{90}$ Felix M. Keesing, "The Taupo[u]System of Samoa:a Study of Institutional Change," Oceania 8, no. 1 (1 September 1937), 7-10.

${ }^{91}$ Keesing, "The Taupo[u] System of Samoa," 1-14. 
replacing of these customs by the missionaries led Samoan women to adopt the Christian rituals and codes of behaviour which Keesing, Mead, and Buxton observed in the 1920 s and 1930s. ${ }^{92}$

The mission schools themselves were also key social instruments which shaped and actively sustained the churches' influence over Samoan women. The church, the mission homes, convents, and Samoan ministers' residences were key sites for the adoption of Christian moral codes and practices instead of the aualuma. Parents were encouraged to allow their children to live with the pastor and his wife where they were taught Christian virtues, bible reading, writing, sewing and housekeeping while also carrying out chores. ${ }^{93}$ In short young women were being prepared to be church ministers' wives. As spiritual parents, the pastor and his wife had more influence on young women's lives than their real parents. It was generally the village pastor who selected some of the older girls to pursue further religious and home economics training at the two traditional LMS boarding schools for girls, Papauta Girls' School in Western Samoa, and Atauloma Girls' School for the Tutuila and Manu'a girls. ${ }^{94}$

The Christian reconfiguration of Samoan women's agency eroded the position of Samoan women as feagaiga or the covenant. The cultural honorifics and significations for women shifted to the church ministers and their wives, which further removed women from their central place in society. ${ }^{95}$ Since the arrival of the missionaries, Samoan women's traditional institutions have always been an area of contention in shaping Samoan women's lives. In negotiating this uneven terrain to find a balance between the fa'asamoa and Christian ideals, many aspects of Samoan women's agency were removed from the centre and became what Stuart Hall referred to as 'actively marginalised' in their own culture. ${ }^{96}$ With their political agency reduced, the women's status was relegated to the margins and their worldview became more Christian in

92 Buxton, Researches in Polynesia and Melanesia; Keesing, "The Taup[o] System of Samoa"; Margaret Mead, Social Organisation of Manu'a, vol. 76 (Honolulu: Bishop Museum, 1930).

${ }_{93}$ Elizabeth Marchette Roach, "From English Mission to Samoan Congregation: Women and the Church in Rural Western Samoa." (PhD thesis, Columbia University, 1984).

94 Roach, "From English Mission to Samoan Congregation".

${ }^{5}$ Latu Latai, "Changing Covenants in Samoa? From Brothers and Sisters to Husbands and Wives?," Oceania 85, no. 1 (2015): 92-104.

${ }^{96}$ Stuart Hall, "Notes on Deconstructing 'the Popular'," in Cultural Theory: An Anthropology, ed. Imre Szeman and Timothy Kaposy (West Sussex: Wiley-Blackwell, 2011), 72-80. 
character. These changes to women's agency were fundamental to shaping their roles in families and villages in the 1930s.

All the participants have attested to the importance of the church in shaping and their lives. Faanunumi and Faapusa spent all their youth at the Faifeau's residence. Tuala's mother, for example, was always reminded: 'don't you forget, you are a pastor's daughter! ${ }^{97}$ These reminders carried the Christian expectations of behaviour and they also implied the existence of the very opposite of these values. Faafouina Selesele of Satupa'itea refused to live her life according to such an outlook. Born in 1927 into a chiefly and politically active family, there was an expectation that Faafouina would be a role model for other village women especially when her father ran the village. As we shall see later, however, this was not to be.

On the eve of the war life for those who attended the LMS and Catholic boarding schools was also 'governed by many'. The church, the culture, individual and family situations all contributed in shaping women's lives. The parents who were less inclined to interfere with how the Church molded their daughters into Christian young women that were suppose to be virtuous and obedient. But there were others who did not conform to such expectations. The war gave some of the young women some leeway to socialise and enjoy the new vistas and encounters with the American marines within the churches that were already beginning to feel the pinch of the war on their authority.

Also driving change within the aualama were the health care programs spearheaded by the administration since 1921 and at the village level by the komiti tumama - sanitation committees. Initially established by the missions the komiti tumama were reconfigured and adapted into the aualuma, complementing its traditional healing functions. The drive to improve health through the use of aualuma's agency in its executive role, gradually chipped away at the old cultural boundaries differentiating the aualuma from the faletua ma tausi ma ava a tulele'a.

Traditionally, the aualuma seldom shared its cultural space and roles with the faletua ma tausi ma ava a taulele'a. However, in the drive to improve health, the social boundaries came down and all women congregated in the same space. Although the new grouping

\footnotetext{
${ }^{97}$ Hunter-Malietoa, interview.
} 
(the Komiti tumama) provided a new space for women from outside of the village to socialise together with the aualuma, the women in the village setting seldom broke with tradition and the traditional setup of the aualuma was replicated in the komiti tumama, similar to the mafutaga a tina, and the church women's fellowship. What is significant here is that traditional roles were extended and were effectively improved with the knowledge of modern medicine and skills introduced from the nursing schools run by the two administrations.

Samoan women's agency evolved as women incorporated new knowledge and practices into the lives of their families. By the 1920s and 1930s Samoan women's social spaces for engaging with the community expanded. The purpose of the komiti tumama was practical and less restrictive than the traditional groupings. Many individuals preferred this grouping because it had a lot more activities they could apply to their own households. Many saw their role in the komiti as an extension of their family roles in ensuring village hygiene. Frequent monthly village inspections and heath activities became synonymous with the komiti rather than with the aualuma.

Being the culturally appointed nurses, the village women in their capacity as members of the aualuma/health committee were responsible for giving out medicine to those who needed western medication. The designated chiefly home that hosted the taupou and the aualuma also became the village dispensary. The archival records show that it was the norm for the administration to work alongside the village women to assist in the distribution of these general medications. ${ }^{98}$ The same women's spaces often served as the place where the village, nurses, midwives and occasionally doctors congregated for a range of activities including medical checks for expecting mothers, administering injections for young babies and circumcising young boys. New responsibilities and skills enriched old roles, making these women's groups relevant again.

This chapter's discussion has revealed many forces that influenced Samoan women's lives leading up to the Second World War. It has highlighted that Samoans were accustomed to change; some they were able to control and others they were not.

98 Petition by the chiefs and councillors of Safotulafai to Robert Logan regarding their dissatisfaction with the assistant governor, Williams. Safotulafai, 27 March 1915. R9498619, "Papers Relating to Deputy Administrator Williams," Samoa-BMO2 1, ANZ. 
Political and social power, race and religion all worked together with different intensities to influence women's agency. Throughout the discussion we see the interviewees as young women beginning to make sense of the Samoan society they were born into. Indeed it was in a state encapsulated by the idea of lesolosolou. With time, individuals were able to negotiate and change their lives in a society that was also slowly changing. That slow process of internalised negotiation was about to get its biggest shock ever. 


\section{Chapter Three. The War Arrives in Samoa}

No other historical event can equal the influence of the Second World War for the Samoan people. People's responses to this global phenomenon reverberate down the generations. As in many other parts of the world, the war was a defining moment for the Samoan people. Exploring Samoans' wartime lives, reveals how ordinary individuals' daily encounters during the war were themselves key historical moments.

Epeli Hau'ofa's innovative paradigm of 'a sea of islands' consolidated the goal to address the life experiences of people who were thought to seldom make history. Hau'ofa conveyed the significance of ordinary Pacific islanders as actors of history in his argument that 'only when we focus on what ordinary people are actually doing, rather than on what they should be doing, can we see the broader picture of reality." While there are many levels of history, the experiences of ordinary people in villages and communities are very telling of the realities lived during the war. These ordinary lives are often overlooked by historians who have often failed to recognise the historical moments made in the 'ordinary - ness' of islanders' encounters with the soldiers or wartime circumstances.

This chapter has three parts. The first examines how the events between September 1939 and December 1941 foreshadowed later experiences. The wartime emergency regulations frame this discussion about the veins through which the war permeated the Samoan islands, illuminating the initial changes that occurred before the arrival of US forces en masse in 1942. The second part of this discussion surveys my interviewees' understanding of, and responses to, the arrival of the US troops following the outbreak of war with Japan. Samoan women's narratives of their experiences of the arrival of the US marines, first in American Samoa and then in Western Samoa, provide a portrait of this encounter. This part of the discussion highlights the variety of their responses to, and perceptions of, the GIs.

The third part of this chapter examines the extent of transformation in Samoan women's roles as a result of the changed wartime circumstances. I argue that the transformative nature of the war derives from the demands it made on cultural and

\footnotetext{
${ }^{1}$ Epeli Hau'ofa, We Are the Ocean: selected works (Honolulu: University of Hawai'i, 2008), 35.
} 
physical spaces. Whereas the military looked on land or physical space in terms of strategy and logistics, Samoans viewed the land as fundamental to the faaSamoa, the Samoan way of living. Land or eleele in Samoan, which translate to English as 'blood', is the essence of the culture. The role of every Samoan person is tied to the land. The change in land use for defense purposes by the new occupiers interrupted this close relationship. The impact of these changes can be demonstrated by tracing the changes in Samoan women's daily routines and their roles during the war.

\section{On the Eve of War}

New Zealand and the United States entered the Second World War at different times. New Zealand declared war on Germany in September 1939, a little over a year before the United States declared war against Japan in December 1941. New Zealand immediately enacted the Dependency Emergency Regulations for Western Samoa, the Cook Islands and Niue. These regulations gave the government emergency powers to prosecute the war and were published in the official New Zealand Administration of Samoa Gazette immediately after New Zealand declared war on Germany on 3 September $1939 .^{2}$ The following were the regulations applied to Samoa at the beginning of the war:

Censorship \& Publicity 1939 \& Amendments 1,2.3.

Price Stabilisation 1939 \& Amendment 1.

Defence 1939 \& Amendment 1/

Shipping Control 1939

Overseas Passengers 1939

Supply Control 1939

Aliens 1940

Oil Fuel 1939 \& Amendments 1,2.3.4.

Passport 1939

Enemy Trading 1939 \& Amendments 1.2.

Wheat and Flour 1939

Export Prohibition 1939 and Amendments 1.

Contraband 1940

Enemy Property 1940 \& Amendment 1,2.3.4.

Foodstuffs 1939

Finance 1940

Import Certificates 1939

${ }^{2}$ Memorandum for the under-secretary, Department of Internal Affairs, 1 September 1939, IA1 3046 171/2/1, Wartime Administration Arrangements - Proclamations, Regulations - Application of to Western Samoa, Cook Islands, Niue Island, ANZ. 
Public Safety 1940 \& Amendment 1.

Prisoners of War 1940.

Shipping Seizure 1940

Shipping Safety 1940 \& Amendment 1.

Control of Prices 1939 \& Amendment 2.

United States Forces 1943. ${ }^{3}$

New regulations were added and amendments to the first regulations were made from time to time in during the war. They also greatly affected aspects of Samoans' daily lives. For example, the Public Safety Emergency Regulations, the Censorship and Publicity Emergency Regulations and the internment of Enemy Aliens all had implications for Samoans' daily mobility as they were restricted to their villages.

One of the first wartime regulations enacted in Western Samoa was the immediate internment of the German nationals and part-German Samoans as prisoners of war at Tuvao, a sub-village of Moata'a, on the New Zealand Reparation Estate plantation. ${ }^{4}$ The New Zealand Administration archives reveal that this sector of the population in both territories was under close surveillance. ${ }^{5}$ From Tuvao Plantation, the detainees were shipped to Matiu (Somes) Island in New Zealand despite the fact that some of their relatives living in New Zealand were not subject to the same treatment. A similar process occurred later in American Samoa but to a much lesser degree.

For some German Samoans, their internment at the outbreak of World War II echoed their experiences at the outbreak of World War I when the British military occupation imprisoned their fathers in New Zealand. ${ }^{6}$ The families of the internees had to relive the trauma of losing their parents and the families experienced economic hardship. The Samoan wives of the internees had to rely heavily on their Samoan families for support. ${ }^{7}$

${ }^{3}$ List of Emergency Regulations Issued. IA1 3046 171/2/1, ANZ.

${ }^{4}$ NZ Administrator to Army Department, undated, AD1 1379/336/1/37, Aliens and Prisoners of War Civilian Internees Interned from Samoa, ANZ. See also Christine Winter, "Changing Frames," The Journal of Pacific History 47, no. 2 (2012), 364-67.

${ }^{5}$ NZ Administrators notes on Samoans with German connections, AD1 1379/ 336/1/37, ANZ.

${ }^{6}$ Enemy Alien Report: Fredirich Oskar Christian and Kurt Montgomery Stunzner and Rudolf BerkingAD1 1379 336/1/37, Aliens and Prisoners of War - Civilian Internees from Samoa, ANZ. Mathes was suspected of being a Nazi sympathiser. See also: Andrew Francis, "To Be Truly British We Must Be Anti-German": New Zealand, Enemy Aliens and the Great War Experience, 1914-1919 (Oxford: Peter Lang, 2012); Tony Brunt, To Walk under Palm Trees: The Germans in Samoa (The Museum of Samoa, 2016), http://germansinsamoa.net/wp-content/uploads/2013/09/Palm_Trees_Ebook.pdf.

7 AD1 1379 336-1-37, Aliens and Prisoners of War - Civilian Internees from Samoa, no date, ANZ. 
The anxiety of wartime uncertainty saw individuals hurriedly wed in the most unusual circumstance. A 19 year old Maria Janke married Paul Arno Hessmann, a 31 year old school teacher and German national, at the Moata'a Internment Camp on 18 November 1939. ${ }^{8}$ Paul was interned together with Maria’s father, Fritz Maritin Jahnke, awaiting their transfer to New Zealand.

While neither the participants in this study nor their immediate families were interned, the process of sifting the population to find potential enemies reminded some Samoans of when the New Zealand police ransacked homes to find supporters of the Mau movement a few years before the war. Rounding up the 'Enemy Aliens' intensified the already tense relationship with colonial authorities. Sivao Williams, born in 1919, is from the village of Lepea. She was working for Mr. Eden, the General Manager of the NZRE during the war and was living with the Edens at the Suga plantation, at the village of Vailele, east of Apia. Eden was responsible for the Tuvao plantation internment camp. Sivao recalled that many Samoans at the time were afraid of the 'fitafita papalagi - the white soldiers' even before the arrival of the US forces:

Because they go into people's homes and search their pusa - [clothes] chests and all that. Yes, that was what they did during this time. However, they never came to our house (her family home at Lepea) or Mr. Eden's as well. I was already working as a house maid at Mr. Eden's home when the war broke out. You hear people tell about these type of things happening often. One time I went on the bus to Apia and found out that Vaimoso was under surveillance by the police. I asked why and they said, 'They stop you and search if you are carrying any sharp objects. That is what the police did'. I thought the police were a bit strict at the time.'

Sivao's memory of this incident showed the contrasting scenes in the villages with the heavy police surveillance compare to the NZRE plantation where she lived. To enforce the emergency regulations, the police became more visible out in the town villages. Many Samoans were also afraid of the police because of the NZ administration's previous attempts to suppress the Mau movement.

The emergency regulations included curfews and blackouts, which disrupted people's mobility and alienated the population. In Upolu, Sister Malia Makerita Leauna'i, a

${ }^{8}$ AD1 1379 Aliens and Prisoners of War - Civilian Internees from Samoa, ANZ.

${ }_{9}$ Williams, interview. 
former student of the SMSM sisters at Moamoa, remembered how the blackout regulation frustrated the students who were often told off by the nuns for not adhering to the rules.

The blackouts at Moamoa were a nuisance to everyone. We ate while it was daylight. Come the night we use the candles or the kerosene lamp, but the we have to cover the windows so the light would not be seen from outside. Every now and again the telephone would ring, it would be followed by a nun telling us that the troops were on the phone telling us to turn the light off. So we just sit in the dark. O le faapologa tagata ia. It was like slavery! ${ }^{10}$

While the authorities presented the wartime curfews as a public safety measure, Alice Chadwick (later Alice McElhiney), who was a student of the Convent School at Savalalo, remembers how the curfews targeted some of her friends because they were part-German:

The earliest memory I have of the war was seeing the soldiers on the road with guns in the street.... We mixed with the German kids, half German, half Samoan. In fact, we even go to school with them, and we never thought about them. Then the first thing I noticed with the Americans, they would not allow them on the streets after 6 o'clock. These are the German kids that I know that I mixed with [sic]. They were not allowed, there was no freedom for them, and some of them were brought here to New Zealand. That is my experience of that. In fact, some of them I even know, the young ones but I was not, scared or anything like that. It was just part of everyday living. We did not think it was bad or anything; I know that because you see them on the road walking around in their uniform. They are allowed but when its 6'oclock they would stop them - a curfew. Particular on to the Germans. ${ }^{11}$

In Alice's opinion, the curfews were unfair because they singled out her part-German friends. In the eyes of Alice who was part-English, they were all Samoans. Alice's memory indicates how the regulations not only restricted mobility but forced people to choose sides because the administration identified some Samoans as the potential enemy. The Alien Control Emergency Regulations (1939) did not make any specific distinction regarding the nationality of the 'enemy aliens'. However, Samoans still remembered the internment process during the Great War when German nationals were sent away as prisoners of war. ${ }^{12}$ The $\mathrm{NZ}$ administration urged the villages to abide

\footnotetext{
10 Sister Malia Makerita Leauna'i, interview by Louise Mataia-Milo, 9 January 2015, Vailoa, Faleata.

11 Alice Mary McElhiney, interview by Louise Mataia-Milo, Saturday, April 4 2015, Manurewa, Auckland New Zealand.

12 Francis, "To Be Truly British We Must Be Anti-German".
} 
by the regulations, especially screening all lights which could be seen from the sea. Transport was reduced to save fuel and imported foodstuffs were rationed.

Communications with the outside world also became limited with the enactment of the censorship regulations affecting broadcasting and postal services from September 1939 onwards. The policing of these laws was very invasive. The new rules gave officials the right to search or detain travellers suspected of carrying letters or objects that might compromise national security. Women suspects were taken to a Justice of the Peace or a female member of the administration staff. The situation grew worse still with the Shipping Safety Emergency regulations in 1940 that restricted the movement of merchant ships, reducing the flow of information into the territory to just a trickle. The Western Samoa Mail established in 1901 published local news and notices and heavily censored and outdated war news from Europe until its publication was suspended in March 1942. ${ }^{13}$

The circulation of information about the war was slow to reach the extremely rural villages such as Lefagaoali'i. Tauvaga Lemana, who was a 16 year old girl when the war broke out, first heard of the war by listening to village people's stories: 'I did not see the war, but people came and told me about it. Our family lived too far inland that we did not see many people or signs of the war. ${ }^{14}$ Most Samoans had no access to radio.

Almost all of the participants who lived out in the villages claim that during the war the only person who would have had access to a radio was the church minister. The circulation of newspapers that published government notices and information about the war was mainly limited to the urban areas and seldom reached the rural villages except through the official channels such as the village mayors. Notices were almost always in English. Only the colonial administrators, the politically active chiefs and a few members of the Samoan community were able to access such information. ${ }^{15}$ Samoans out in the villages got information about the war from other villagers who visited Apia or from relatives who joined the construction units in Pago Pago. The different versions

\footnotetext{
13 "Samoan Newspaper Suspends," Pacific Island Monthly, 16 May 1942, Vol. XII No. 10.

14 Tauvaga Lemana Enesi, interview by Louise Mataia-Milo, 17 October 2014, Lefagaoali'i.

15 Prime Minister's Office to the Director of Broadcasting Services, AAD - LW 3363 Box 333, 'Censorship World War II 1938-39, ANZ.
} 
of stories circulated about the war at the village level caused both hysteria and excitement.

The exodus of New Zealand women and children together with other European residents and missionaries starting at the end of 1939 was another sign to the Samoans in Upolu and Savai'i that war was on the horizon. The New Zealand government discouraged missionaries and female travellers who wished to travel to Samoa. ${ }^{16}$ Although the administrators organised evacuations, the final decision to leave was voluntary. Most of the evacuees from Western Samoa were the wives and children of New Zealand officials.

The war also stimulated an outward migration of young abled bodied Europeans and part-European Samoans from Samoa to join the war through enlisting in the New Zealand forces. The rules of the mandate prevented the New Zealand administration from raising an armed force in Samoa. These young enthusiastic Samoans did not meet the blood quantum criteria set by the military which stated that recruits must be 'fullblooded whites and up to but not including, persons of half-Polynesian blood'. The fathers of the recruits, who themselves were British veterans of World War I, objected to these criteria noting that other Samoans who enlisted from New Zealand had no difficulties compared to the men enlisting from Western Samoa. ${ }^{17}$

The administration also sought to accommodate the evacuation of missionaries. The LMS appealed to withdraw the wives and children of its missionaries. Relatives of New Zealand missionaries in Samoa called on the government for assistance to evacuate their family members. ${ }^{18}$ However some missionaries preferred to continue working in Samoa, during the war rather than to return home. For example, Sister Veronica, a Catholic SMSM nun, disregarded her family's plea to the New Zealand Prime Minister to take her out of Samoa. Most of the nuns living in Samoa were French, English, German and American. They all stayed during the war. ${ }^{19}$ All the Mormon missionaries serving in

\footnotetext{
${ }^{16}$ IT1 431 EX69/151 1. Evacuation of Women and Children from South West Pacific Territories WWII, ANZ.

${ }^{17}$ Mataia, "Odd Men from the Pacific: The Participation of Pacific Island Men in the 28 (Maori) Battalion in the Second World War."; "Euronesians Are Not Accepted: Recruiting in Western Samoa," Pacific Island Monthly (15 March 1941).

18 J. S. Hickey to the Right Hon. Peter Fraser, 9 March 1942. IT1 431 EX69/151 1, ANZ.

${ }^{19} \mathrm{NZ}$ Administrator's list of SMSM missionaries residing in Samoa during the war. IT1 431 EX69/151 1, ANZ.
} 
Samoa were ordered by the church headquarters to evacuate back to America except for the head of the mission in Upolu. As a result Samoan men and women stepped forward and took the reins of the church administration during the war. ${ }^{20}$

Meanwhile in American Samoa the preparations for a possible war with Japan resulted in significant development of the territory's infrastructure by the end of 1941 . The program that had been set in motion by Japanese expansion in Asia since 1937 saw Pago Pago Harbour developed into a naval air base. ${ }^{21}$ The coastal guns mounted at the entrance to Pago Pago harbour by 1940 were a sure sign that war was foreseeable. In March 1940 the US Marine Corps' 7th Defence Battalion arrived to provide a garrison for the territory and to work on further building up Samoa's defences. The Seabees, constructed utility roads, buildings for the medical centre and an airstrip at Tafuna. By 1941 the US government had poured in over two million dollars to bring Pago Pago up to standard as a naval and submarine base. ${ }^{22}$ Although the construction might have been seen by the local population as development, the fact was that the Americans were getting ready for war and Samoa was seen as an important strategic point between the United States and Australia

The construction work was a dynamo that generated many different experiences for Samoans prior to the arrival of the main body of the marines in January 1942. The Samoan population provided labour for construction. Many Samoans travelled from Western Samoa to join the construction crews in American Samoa, learning new skills along the way. ${ }^{23}$ The construction work appealed to Samoans because of the high wages paid by the US forces. The opportunity to earn money from the war build-up came at a time when both territories were experiencing copra deficits. The New Zealand Reparation Estates had suffered a loss of profit with the plummeting of international prices. The governor of American Samoa informed the Fono in 1940 that expenditure

20 R. Carl Harris, Building the Kingdom in Samoa, 1888-2005: History, Personal Narratives, and Images Portraying Latter-Day Saints' Experiences in the Samoan Islands (Heber City, Utah: Harris Video Cases, Inc., 2006).

21 Stephen Ronald Maynard, "Marines Defense Battalions, October 1939 - December 1942: Their Contributions in the Early Phases of World War II" (MA thesisUniversity of North Texas, 1996), 93-5.

22 Pacific Island Monthly XI, no. 7 (14 February 1941); Kennedy, The Tropical Frontier, 202-3.

23 Telegram from ADMOR (Apia) to Wellington, 19 April 1941, ACGA 8280 IT1 211, ANZ. 
would exceed income and suggested an increase in the poll taxes and in production of copra, mats and curios to improve the territory's income. ${ }^{24}$

The inter-island migration between US Samoa and Western Samoa provided an informal channel for the circulation of information about the war. War construction in Western Samoa did not start until 1942, after the US Command signed an agreement with New Zealand. In 1945 the Attorney General in US Samoa noted that the 'phenomenal increase [in the population] since 1940, is due to workmen and their families coming here to work in the war effort, mostly from Western Samoa.' Evidence of this, according to the Attorney General, was the fact that from 1940 to 1945 the population decreased slightly in the Manu'a district, where there were no war activities but increased significantly in the eastern and western districts where work war was being done..$^{25}$

The manufacture of floor mats and other light handicrafts brought Samoan woman into the economically active population, contributing to the economy in their traditional role as weavers or fai oa - treasure makers. Governor Wild manifested his confidence in the possibility of a viable market for Samoan women's handicrafts. He predicted in 1940 'that next year will show a much larger increase due to the expansion program of both the Army and Navy in locations where climatical conditions make the Samoan floor mat desirable. ${ }^{26}$

In the 1920s the US naval administration had established a Department of Native industry to encourage Samoan artisans to continue carving and producing traditional weaving that could be sold to foreigners. ${ }^{27}$ The administration played a central role in controlling the prices in the trade of a variety of Samoan handicrafts, such as wood carving, necklaces and especially a variety of Samoan mats and siapo. These activities benefited women's groups in the 1930s and the early 1940s. Villagers sold these items to the passengers of the Matson cruise liners. Tiresa Fiti Brown confirms that before the war one of the biggest earners for women in the village of Vatia, aside from cutting

\footnotetext{
24 AG to the Governor, 22 August 1945. T-1182 ROLL 32 Part 1, "Records of the Government of American Samoa," NARA.

25 AG to the Governor, 22 August 1945. T-1182 ROLL 32

26 Annual Fono Proceedings, Governor's Address, 1940. T-1182 Roll 56. "Records of the Government of American Samoa," NARA.

27 T-1182 ROLL 18, "Records of the Government of American Samoa," NARA.
} 
copra, was weaving 'fala oka - ordered mats' for money. ${ }^{28}$ The Naval administration predicted a lucrative business with the changing wartime conditions and encouraged the manufacturing of these Samoan handicrafts.

Wartime restrictions meant, however, that the villagers could no longer offer cultural entertainment for foreigners, especially in the northern coastal areas of American Samoa. People had grown accustomed to socialising with the tourists they hosted and danced for when the 'Meli' arrived. ${ }^{29}$ Dance groups, especially in the south coastal communities of Lauli'i, Fagaitua and Aua hosted siva for the tourists. With the changing conditions in early 1941, the administration banned passengers from the Matson cruise ships that frequented Pago Pago from going beyond Aua, which meant a loss of income and interaction with outsiders other than naval personnel for the villagers in Fagaitua and Lauli'i. ${ }^{30}$

Restrictions on movement also came into effect. The usual malaga parties were also forbidden without written permission from the Attorney General. These restrictions were introduced just as US Samoa was recovering from a famine caused by the 1939 hurricane that threatened food security. The Manu'a representative to the fono recommended a ban not only on the malaga but also on other traditional practices such as funeral feasts which stretched already limited resources. ${ }^{31}$ The other district representatives successfully opposed the Manu'a recommendation, but slowly, even before the United States entered the war, mobility was being restricted and people's daily routines disrupted, and cultural interaction limited to the villages in which people resided.

Blackout regulations which had been enforced in Western Samoa since September 1939 came into effect in American Samoa from December 1941. In Olosega, Manu'a villagers were instructed by the chiefs to go inland to the old forts while the chiefs and the Samoan marines patrolled the coast line to ensure the villagers kept to the regulations. ${ }^{32}$

\footnotetext{
28 Tiresa Fiti Brown, interview by Louise Mataia-Milo, 12 December 2014, Vatia, American Samoa. 29 'Meli' (the transliteration of 'mail') is a common term given to cruise ships and other ships that came into the ports of Apia and Pago Pago.

${ }^{30}$ Loia Sili o Amerika Samoa i le Pule o le Tiute e uiga i le mataupu O siva i aso Meli, Mati 31, 1941. T1182 Roll 56. "Records of the Government of American Samoa," NARA.

31 T-1182 Roll 20, "Resolution of the Chiefs of Manu'a, 1939 and 1940," NARA.

32 Letuli to the Attorney General 14 July 1940. T-1182-Roll 20, NARA.
} 
Saunia remembered how families were fined if they were caught with the fire or embers still on in the night at the Fitiuta. ${ }^{33}$ People were not allowed to light fires at night, so there were no more night activities for the villagers.

In Leone, young people like Amanda were anxious because of the darkness, and because it restricted their evening routines. Many older people were frustrated because they had to reorganise their lives around these curfews and blackouts.

One of the things I was scared of, was the six o'clock curfew. There was the Catholic Church that had a clock and the bell goes at 6 [in the evening] for the Angelus. This was the time for every family to eat. There were no lights. We sit in the dark, talk in the dark, sleep in the dark. My father and many of my cousins were all working with the Marines but they get home to early. We eat at six $(6 \mathrm{pm})$, do the evening prayers first before eating. When we finish eating it is already dark... we could not wash the dishes until the morning because lights were not allowed. The cigarettes, the old people would hide behind the mat and draw the pola blinds of the house, but still they could see him. One Samoan guy [Samoan Marine] called out, 'close your smoke... 'The funny thing was if someone wants to smoke, they have to put the pola down but they can still see it from outside. So they had to put it out! Many of the old men who like to smoke their Samoan tobacco with the lau sului (dried banana leaves) could not do it at night. ${ }^{34}$

The disruption to simple daily routines initially caused much anxiety, but sustained disruption normalised the change and the villagers became used to living in the dark.

In Samoa, the Second World War's transforming potential had not been immediately apparent when war broke out in Europe in September $1939 .{ }^{35}$ The war initially was in Europe and North Africa, far away from the Samoan world, and people were not overly concerned. However, this analysis of the wartime emergency regulations and their implementation shows how Samoa's colonial status placed the two territories in a vulnerable situation. The different levels of activity on the New Zealand and American sides reflected the different priorities of the two administration.

Samoans saw the war approaching by watching the activities of foreigners as dictated by the implementation of emergency war regulations. The initial war regulations suddenly

\footnotetext{
${ }_{33}$ Pa'au, interview.

34 Iuli, interview.

35 Judith A. Bennett, "Fears and Aspirations: US Military Intelligence Operations in the South Pacific, 1941-1945," The Journal of Pacific History 39, no. 3 (2004), 282-4.
} 
disrupted the lives of Western Samoans in late 1939, but it was a more gradual process for the American territory. The Naval administration of American Samoa with its regular meetings with the chiefs was more efficient and tolerant in its approach compared to the New Zealand administration which was seen by villagers as more invasive. The internment of the perceived enemy, the evacuation of foreigners and censorship subtly restricted the mobility of the local population, forcing people to adjust their lives and routines to conform to the wartime situation. Restrictive wartime regulations tapered everyday lives.

The effectiveness of the rules received their first test when Japan unleashed its attack on the US Naval Base at Pearl Harbour on 7 December 1941, causing the United States to enact all the wartime regulations that it had been planning for many years. On 8 December the US declared war against Japan, taking all its Pacific possessions into the war and making American Samoa vulnerable to attack. As expected, American Samoa became a target.

The Japanese attack on Pago Pago harbour on 10 January 1942 was the baptism of fire that the Samoans did not want. A Japanese submarine surfaced off the coast of Fagasa in the north and fired 14 light shells towards the Naval Station. Only three people were slightly injured, and ironically one of the shells hit the house of Frank Shimasake, one of the four long time Japanese residents at Utulei. ${ }^{36}$ There were no deaths, but the attack brought home the message that 'a shooting war has reached Samoa.' Saini's memory of this incident reveals the very real potential of war horrors that was almost unleashed by the Japanese attack.

That incident happened when I was in Tutuila at Fagatogo. It was chaos in Fagatogo at the time! I heard a loud gun/cannon fired from Fagasa (a village on the northern side), and it fell at the wharf. I think it was trying to hit the wireless post, that long thing [wireless post] for the wireless but it did not come down. Sa matua'i vevesi ai a Fagatogo i lea mea! ${ }^{37}$

\footnotetext{
${ }^{36}$ Kennedy, The Tropical Frontier, 207; "Progress of the War in the Pacific," Pacific Islands Monthly XII, no. 6 (15 January 1942), 11; J.A.C. Gray, Amerika Samoa, 241.

37 Saini Mauga Milo, interview by Louise Mataia-Milo, 4 December 2014, Ta'u, Manu'a.
} 
The only Samoan defence at the time of the attack was the $7^{\text {th }}$ Marine Defense Battalion, the Fitafita and the first Samoan Battalion of about 160 men referred to as the Samoan Marines (Malini) who were still under training. The Naval station lacked weapons and had no way to retaliate despite the military build-up that was well underway. The chaotic and fearsome state of affairs in Tutuila after the 'bombing' brought home the reality that war had arrived.

Saini's narrative reveals how some Samoans understood the attack and how unprepared the local population was on what to do in the event of an assault by the enemy. Amanda recalled how this real incident caused the US Naval officers to evacuate their wives and children to her village of Leone. This reaction was contrary to Samoan understandings of what to do in wartime.

We often hear people say to get ready because there was a war coming. That was always the story, but it was only over at the police station (at Fagatogo) that was busy. I was at Fagatogo because my sister was there, she married to a person from Fagatogo. People kept depending on the police who said that all families should have a plan of where to run to when an attack comes. My sister told me, if ever there is a war, we are not going anywhere. We will just stay at her home. However, I was not scared; I just wanted to find out where we were going to run to when it comes. However, I left Tutuila for Manu'a, and it was in a chaotic state because of the Japanese attack. ${ }^{38}$

Saini suggests that some people were oblivious to the urgency of the situation and unaware of the potential consequences of not heeding the evacuation processes. The inclination to stay home stemmed from the belief that the war would be a showdown between the American and Japanese forces and that Samoans would only be observers. However, unknown to Saini and the rest of the Samoan population, more wartime sojourners were about to enter Samoan waters and to change their lives like never before.

\section{The Arrival of the War}

The main body of the US forces sailed into American Samoa carried by three luxury ocean liners, the SS. Lurline, Monterey, and Matsonia, on 20 January $1942 .{ }^{39}$ They

\footnotetext{
38 Milo, Interview.

${ }^{39}$ Kennedy, The Tropical Frontier, 206-07.
} 
brought 5,600 officers and enlisted men of the $2^{\text {nd }}$ Brigade of the $2^{\text {nd }}$ Marine Division, the first American expeditionary forces to leave the United States after the declaration of war against Japan. Other parts of the same convoy carried the machinery, artillery, and ammunition. The arrival of the convoy in Pago Pago harbour was a welcome assurance to the naval authorities and the Samoan population following the fears raised by the Japanese attack on Fagatogo wharf. The population of American Samoa, which was about 12,900 people (including about 8,000 indigenous Samoans) almost doubled overnight. ${ }^{40}$ There were times during the war when the marines outnumbered the local people.

The arrival of the $2^{\text {nd }}$ Marine Brigade created an awkward political situation in American Samoa. General Henry Larsen, who led the $2^{\text {nd }}$ Marine Brigade, outranked the governor in office, Captain Laurence Wild. Shortly after the landing, Captain Wild assumed the role of senior officer while Larsen was appointed the Military Governor of American Samoa.

Larsen promptly set about organising Samoa's defences by prioritizing communications and transport infrastructure. ${ }^{41}$ The airfield at Tafuga (now Tafuna) was only 10 per cent complete when the brigade arrived, so this became the priority. The $8^{\text {th }}$ Marine Regiment, one of the principal units, assumed beach defence duties and the $2^{\text {nd }}$ Defence Battalion began the installation of seacoast and anti-aircraft artillery batteries to protect the airfield which became operational in March 1942. The $2^{\text {nd }}$ Marine Brigade continued the work of the $7^{\text {th }}$ Defence Battalion through the construction of roads and communication lines further away from the harbour and into the villages. Six weeks after arriving in American Samoa, they completed the road from the north to the south of the island and the communication lines and switchboard connections to all the key units. $^{42}$

Larsen also issued wartime regulations such as evacuation orders that removed the wives and children of American naval officers to Hawaii. Censorship was established, and warnings were issued against infringements. He also set about 'identifying filth' and

\footnotetext{
40 Stephen Ronald Maynard, "Marine Defense Battalions", 106-09; John Wesley Coulter, The Pacific Dependencies of the United States (The MacMillan Company: New York, 1957), 76.

41 Maynard, "Marine Defense Battalions," 119-20.

42 Maynard, "Marine Defense Battalions," 119-20.
} 
placed under close watch a handful of German nationals, including some German Catholic missionary teachers and four long-time Japanese residents. ${ }^{43}$

Young people were amazed at the physical presence of war as it came ashore. The spectacle of seeing the inbound ships unloading their war cargo excited and captivated them. Amanda from the village of Leone, on the south-west coast of Tutuila, describes the first time she saw the landing of the US Marines and their equipment at the harbour in Fagatogo:

We went on the bus to the market at Fagatogo. We were stunned! We saw a warship come up to the dock. The side of the boat came down, and vehicles came on to the ground. I was wondering how it would sail back again into the deep since it was so close to land. There were a lot of jeeps, trucks, and all that! I think we were there to go to the hospital, but we decided just to sit there all day and watch this incredible event. ${ }^{44}$

Bound up with the novelty of this massive arrival were feelings of apprehension when the troops began to penetrate the villages. In Leone, Amanda had the impression that her front yard suddenly had become a frontline when the families were forced to accommodate the new visitors. At the age of 87 , Amanda vividly recalled the scene in her village when the American soldiers arrived in huge trucks with heavy artillery:

Leone is a big village with many big fales [Samoan houses] commonly used to host guests, and the community respects the homes as culturals spaces. They did not stand a chance. The maligi came and filled them with 20 punk [beds] each and lived there. All the fale tele of Leone filled with maligi! Outside, in the front and behind the houses of Leone, were all filled with tents. The school where I taught was stocked with ammunition. The officers took over the convent and the rectory. We were stunned! It was the first time I saw so many people! All those marines, and artillery trucks. They came and opened the [school] house without even asking! I suspect that the rest of Tutuila was like that, but I speak of Leone because it is my village. The Marines took over the whole community. ${ }^{45}$

Another village that had a similar experience was Nu'u'uli, a regal paradise of political significance which straddles the Western and Eastern districts of American Samoa. ${ }^{46}$ As well as being the biggest village in American Samoa, Nu'u'uli was also the stronghold of

\footnotetext{
${ }^{43}$ Kennedy, The Tropical Frontier, 206-9.

${ }^{44}$ Iuli, interview.

${ }^{45}$ Iuli, interview.

${ }^{46}$ Nanatiifaleifeauatamalii is the Taupou title for the chiefly family of the title Savusa.
} 
the Mau movement in Tutuila in the $1920 \mathrm{~s} .{ }^{47}$ White sand carpets this secluded coastal haven which shelters the many village fales that host the council of the tripartite titles that rule Nu'u'uli. ${ }^{48}$ Nanati was ten years old when the marines flooded her village with white men in uniform and heavy equipment. The hefty and tawny coloured artillery contrasted with the natural white carpet of the coastal village. For Nanati the presence of all these things crowded the usually open space creating an unsettling atmosphere on the home front. The open space which she perceived as her playground was occupied overnight. The villagers were forced to go sideways from their common pathways because the space was occupied by the machinery of war. Nanati described the scene in her village when the maligi arrived.

This village [Nu'u'uli] does not have grass lawns. It is all sand. When it is sunny, you can hardly open your eyes. The whole village, even behind the houses it's all white sand. When the maligi arrived, over there [pointing to the front yard by the sea], e te alu fa'atafatafa ua tumu i taavale tau - you have to go sideways, it was full of military trucks. Behind here [pointing to an area behind the house] was where the hospital for the soldiers. On the side there where my cousins' houses are [pointing her hand to the right where two houses now stand], that area was their mess hall. It was here in our village where the 'Fa'afetu tasi' ${ }^{49}$ was based. That was the highest ranked officer who looked after the whole thing. He stayed in the house up at the top of that mountain [pointing to the hill which overlooks the village]. ${ }^{50}$

Nu'u'uli transformed from a secluded, peaceful village to a military camp, disrupting village life. Like the people of Leone, the Nu'u'uli villagers had to reorganise their lives to accommodate the marines with whom they had to share their village.

Remote villages did not escape the military presence. Vatia, on the northern side of Tutuila, nests in a narrow crescent shape strip of land and could only be accessed properly by sea. People seldom travelled out of Vatia unless it was essential. Normally, they would cross the mountain to the next narrow valley of Afono which was a whole day's travel by foot. ${ }^{51}$

${ }^{47}$ Meleisea and Schoeffel, ed. Lagaga.

${ }^{48}$ Nu'u'uli village has three paramount chiefs.

${ }^{49}$ Faafetu tasi - One-star. In the US armed forces, the One Star ranks often refer to either a Brigadier General in the Marines or a Rear Admiral in the Navy.

50 Savusa, Interview.

51 Sopo - to journey by foot. 
Tiresa, a teenager at the time, remembers that the war reached Vatia on board a 'vaa kalesini-kerosene boat.' The boat brought iron rods, steel beams, big and small ammunition and barbwire for building barracks and coastal fortifications.

They brought in Palagi and Samoan marines to look after this village. They have their training, and we would go to watch. The old men of the village told us to go away, but instead, we try to get close. When the ships came, we were all excited watching them bring guns, cement, iron steel, the spikey ones. It was all new to us. We saw how they put up all the fencing of all the shoreline of vatia. ${ }^{52}$

The arrival of the troops and their hardware overwhelmed young people like Tiresa who was anxious and kept asking a lot of questions to her parents about the marines. Tiresa saw how the beach was planted with barbwire and pillboxes. She asked her parents what all this meant if they wanted to go to the sea?

The people (marines) said its part of the defence in case there of an attack and this [fortification] would make it difficult for them to come straight at us. I thought to myself, oh that is nice. My mother said it should be okay because they have put up a gun by the sea as well. ${ }^{53}$

Many young people did not understand straight away what all this meant, so they had to rely on the older people to explain the new changes in their environment.

The islands of the Manu'a group were considered by the US war office to be less exposed to attack, and they had not been much affected by the build-up, but this did not mean that they were left alone. The war brought devices never seen before in remote parts of Samoa. Saunia Aupa'au's earliest memory of the war was chasing after an aeroplane that flew above her village, Fitiuta, on the island of 'Ta'u.

I remember the first thing I was aware of the war, was an aeroplane flying very low. The kind they [the military] used for the war. We ran after it to take a good look at it but it kept flying - matou o tuli tamo'e! Moreover, when we could not chase it anymore, we all stopped and danced in the middle of the village because we were excited. It was the first time I saw an aeroplane. Our parents saw us and called us back, but we were all blissful about it. ${ }^{54}$

52 Fiti-Brown, interview.

${ }^{53}$ Fiti-Brown, interview.

54 Paau, interview. 
The sight of an aeroplane over Fitiuta created a wave of excitement. for Saunia and her siblings and friends.

The feelings of excitement, amazement, overcrowding and apprehension described here represent the mixed emotions and ambience associated with the war when it first appeared in American Samoa. Young people's impressions varied substantially, reflecting the different responses around American Samoa. New mixed emotions shaped expectations. While there were anxieties in the beginning because of the fear of the unknown, there was also an element of adventure. Similar vistas opened up on Upolu and Savai'i when the GIs reached Western Samoa.

Before any US troops could be deployed to Western Samoa formal arrangements for the defence for the Samoa Islands had to be made between the two colonial administrations. The US War Department estimated that despite the war construction and planning, the security of American Samoa was still weak because of its proximity to other undefended islands such as Western Samoa, the Union Islands (Tokelau) and the Wallis Islands, a French territory. ${ }^{55}$ To the US Command, the lack of a strong garrison on Western Samoa posed a possible threat to the security of American Samoa and communications between the US and Australia. ${ }^{56}$ To pre-empt such a threat, New Zealand, and the United States negotiated and signed an agreement on 20 March 1942 in Tutuila to create the Samoan Area Defense Group. ${ }^{57}$

The purpose of the March 1942 arrangement was to 'ensure that the United Forces may be established in Western (British) Samoa with the utmost dispatch and enable the defense of American and British Samoa to be considered and treated as one by the Commander of the American Forces. ${ }^{58}$ The terms of the agreement made the American Samoa Naval administration and the New Zealand administration relinquish all defensive power to the Military Governor of American Samoa. Their authorities were

55 "Committee of Imperial Defence - Strategic Importance of the Pacific Islands, 1937" http://www.secretintelligencefiles.com/Content/swwf.cab56/0002/033.

56 Maynard, "Marine Defense Battalions," 128.

${ }^{57}$ Maynard, "Marine Defense Battalions," 122.

58 US Forces in Western Samoa Agreement between USA and New Zealand. WAII 1517 DAZ 121/9/B10/5," ANZ. 
limited to civilian matters. This might have been a blow to the administrators' authority, but it was beyond their control - just as it was for Samoans more generally.

The $7^{\text {th }}$ Marine Defense Battalion of the US Marine Corps reached Upolu from American Samoa on 27 March 1942, a week after the agreement was signed and before the arrival of the planned occupation force, the $2^{\text {nd }}$ Marine Brigade. The Western Samoans watched in awe as troops unloaded ammunition, vehicles, bulldozers, and tractors at Vaiala. The island's garrison increased from a Local Defence Force of 50 to nearly 6,000 marines, creating a formidable stronghold.

The New Zealand administration was committed to assisting the US Forces with logistical organisation of the villages with regards to spaces for the US Marines to use. A letter from A.C. Turnbull, the Acting Administrator, to Brigadier General H.L. Larsen in Pago Pago outlined this 'wholehearted cooperation' with attached reports outlining the available resources for billeting accommodation. ${ }^{59}$ The Malifa and Leifi'ifi school compounds became army barracks and storage sites for ammunition and officers' accommodation. ${ }^{60}$ Tuala was a student at Leifiifi School when the marines arrived. 'The Marines took over our school at Leifiifi. They stayed there, and the school hall was all filled with weapons. However, our classes continued and we had our classes in some of the family's houses'. ${ }^{61}$

The churches at Malua (LMS), Piula (Methodist), Pesega (LDS) and Moamoa (Roman Catholic) also cooperated with the provision of accommodation. The Race Course, now the Apia Park at Vaiala and Moata'a, was one of the first points of call for the marines once they disembarked. The Race Course, the golf club pavilion and the band stand quickly attracted the young foreigners. ${ }^{62}$ Villagers who lived near the Race Course saw how the happy young men would often whistle to the women while they went about their chores. ${ }^{63}$

Further inland, the Papauta Girls' School came highly recommended by the Acting Administrator as suitable accommodation with an excellent water supply and sanitation

\footnotetext{
${ }^{59}$ US Naval History Division, "US Naval History of Western Samoa," Micro-MS-0850-1, ATL.

${ }^{60}$ Leifi'ifi and Ifi'ifi school refer to the same school.

${ }^{61}$ Hunter-Malietoa, interview.

62 US Naval History Division, "US Naval History of Western Samoa," Micro-MS-0850-1, ATL.

63 Mataia-Milo, "There Are No Commoners in Samoa," 54. 
system. Isapela Mata'utia was at Papauta School. Like its sister school in Tutuila, Atauloma Girls' School, Papauta was open at the beginning of the war but it later closed. The first American troops arrived and were billeted there. Isapela, who grew up in the Ellis Islands (Tuvalu) with her father's family, had to go to her mother's village of Matautu in the district of Falealili, on the southern side of the island. She shared how her schooling was cut short and how the war followed her to Matautu:

I went to my mother's village, at Matautu Falealili. At that time, the people were getting ready for the war. Word came that the troops would arrive at Falealili. The pulenu'u (village mayor) sent out a message to everyone in the village to get ready. When the soldiers arrived, they were placed in the prayer house. No one was allowed by the Chiefs to go to that house. No women! No women or children! They ate by themselves. ${ }^{64}$

The quarantine treatment by Matautu differed from how the village of Solosolo, in the eastern district of Anoama'a, responded to the marines' arrival. Faasalafa Leota remembered that the first time the marines entered Solosolo, the villagers mistook them for the New Zealand troops hunting the seditious Mau supporters.

The Pastor's house is located by the road towards the beginning of the inhabited part of the village. Whenever the minister's wife see soldiers come, I remember this when I was young. She would put on the church minister's robe and go outside to ring the church bell as if it is a call for people to pray. However, it was a warning to the menfolk that the soldiers were coming to get them. All the men would run into the bush to hide because they were scared. There was one incident when one old man ran naked in fear. This was during the day. At night when they come, the men would climb the thatched roofing and hide there until the leave. They come to look for the blue, i.e., lavalava and tear away the 'mua' stripe. That was how our village reacted when the American marines came. ${ }^{65}$

The villagers interpreted the arrival of the marines in their village as the New Zealand administration's retaliation for their involvement in the Mau movement.

The northern west coast of Upolu was recommended by authorities as the ideal site for an airstrip. The New Zealand administration provided land for this purpose, and the $3^{\text {rd }}$ Marine Brigade went to work on building the Faleolo airstrip (now the Faleolo International Airport) in April 1942. The village of Magia, next to Satapuala, became the headquarters for the newcomers. The population in Magia and the nearby villages

${ }^{64}$ Isapela Malautea, interview by Louise Mataia-Milo, 13 December 2014, Lauli'i, American Samoa. ${ }^{65}$ F.Leota, interview 
expanded with the American troops and the Samoans who managed to find work there. Some families were resourceful and operated restaurants from their homes in Magia. Mrs. Ella Stowers, for example, ran a family eatery at Magia. ${ }^{66}$ The military command also built an entertainment centre, the "Pearl of the Pacific", near Satapuala for the enlisted men to encourage them to socialise within the vicinity of the barracks and not to drink in public or share alcohol with Samoans. The officers frequented their clubs at the hotels in Apia. ${ }^{67}$

Other units of the brigade took care of various aspects of defence. The Seabees and other units constructed the cross-island road from Leulumoega to Lefaga between 1942 and 1943. Other detachments covered Savai'i. Many of the troops complained that the Western Samoan defence build-up was too much work for the men. Other detachment companies, such as $G$ Company of the $2^{\text {nd }}$ Battalion of the $7^{\text {th }}$ Marines, were stationed in the villages of Savai'i.

Although Savai'i was ill suited to the US marines' strategies because of its high topography, a military camp was setup at Sapapali'i, the village made famous by the arrival of Reverend John Willams when he brought Christianity a century before. It was here that Isabella Ryan first saw the American marines. She remembered her first encounter with the war splendidly.

The first time we saw the marines we were driving past Sapapali'i. They were based there. We saw them all lined up. They were on parade in the early morning about 7 or 8 and I thought, what a lot of palagil Oka Oka e, gei mau palagi! Because there were hundreds of them, one row would be a hundred, in their boots and their soldier uniform, light brown in colour. All these marines in full uniform! And the commander instructing them. We stopped the car and watched. I was amazed, and I thought wow! To me war was exciting. Ha Ha! $!^{68}$

Like her American Samoan peers, Isabella reflected on how she remembered her first impressions of the war as a young girl and she resolved that this episode of her life was 'exciting' because of the new people to look at and the activities that broke the

${ }^{66}$ BBAE 1570 A645 1115/ P520/1953. "Stowers, Isabella - Magir, Apia, West Samoa - Married Woman." ANZ.

${ }^{67}$ Alailima, Aggie Grey.

${ }^{68}$ Ryan, interview. 
monotony of island life. The newcomers became the new buzz. Isabella recalled how her new American neighbours brought new thrills to her as a child.

They lived next door to us, my memories of them was, when you are asleep in the early morning, you can hear them marching in their boots doing their training. E patapatatū mai se'evae i le mamafa i luga o vao ma ma'a -Their heavy boots thumping on the grass and stones. There were 50 here at Tuasivi, they spread out like that, and Faga had 50, mainly along the coast here at the Fa'asaleleaga district. I don't know about Upolu. ${ }^{69}$

But the older people did not easily share the young peoples' fascination with the marines and their unusual activities. A lot of them were anxious because of the uncertainty the war brought. Isabella experienced her parents' fear:

I remember mama and papa were always worried because of the war! The Samoans out of the government, what I remember was, e fefefe [scared]! Even in school, my friends would say, 'Tafefe i le taua! Tafefe ae o'o mai Sapani' (In distress because of the war! In agony, if Japan gets here.) The older people were anxious, afraid of the Japanese. But the marines who were all palagi but about two who looked Japanese, you know, you did not know what a Japanese look like, at the time, but the kids pointed them out, other 12 year olds like me. They said, 'o sapani lae, e lua sapani la ei o i maligi - Japanese there, two Japanese with the Marines. ${ }^{70}$

Older people tended to ignore the young children at play around them while they talked. The children too were trying to make sense of the sudden change in village life and absorbed the adults' conversations. Isabella and her school mates created their own images of what a Japanese looked like.

When the novelty of the troops' arrival wore off, the anxiety began to seep further into society. Tuala reflected that her older relatives opposed the war and the presence of the marines and this, in turn, influenced her opinions. In a raised voice she responded: ' $\mathrm{E}$ leai! E lei fiafia i ai tagata! - The people were not happy about it! Because there would be a war, killing people! We did not want people killed. Moreover, there were too many Americans coming. We wanted the war to finish and those people to return to their home. ${ }^{71}$ These critical attitudes, often expressed in the privacy of homes, were kept hidden when in public. For example, one of the New Zealand songs taught at Leifi'ifi

\footnotetext{
${ }^{69}$ Ryan, interview.

${ }^{70}$ Ryan, interview.

${ }^{71}$ Hunter-Malietoa, interview.
} 
school was the famous Maori Battalion anthem, 'Ake Ake Fia Tau e'! According to Tuala, "We used to sing the Maori Battalion war song. But we changed the last part to Samoan - Fia tau e! (Wanting to fight) However, we did not want the war. We wanted it to finish! (Humming the tune of the Maori Battalion song). ${ }^{, 72}$

\section{Responses to the Arrival of the US Marines}

The arrival of the US troops in Western Samoa was an event of colossal scale beyond the comprehension of most young Samoans. The arrival of so many uniformed foreigners broke the monotonous tone of everyday island life. My interviewees' initial encounters with the war in different corners of the archipelago reveal different understandings of and responses to the arrival of the war. The reflections of Tuala and Isapela Mata'utia illustrate the suspicion of the older people about the war and their attempts to contain the marines to the end of the village. Others like Amanda, Tiresa of Vatia and Isabella found the arrival of the war an exciting event. The marines brought a new thrill which made a break with their 'boring' lives. In some places, such as Solosolo where the US marines were mistaken for the New Zealand police hunting the supporters of the Mau movement, the war's arrival was seen in relation to the local political context.

These first impressions also illustrate the range of emotions experienced when the marines reached the Samoa Islands. Astonishment was mixed with fear and excitement. However, the euphoria of the first arrival soon passed as the GIs began to consolidate the defense of the Samoa Group by building the airports and the utility roads. Military installations changed the features of the land, restricting people from their usual routes to perform the roles expected of them.

Oblivious to all the bureaucratic and military manoeuvres, the villagers found themselves having to renegotiate their lives to adjust to the wartime circumstances. The first experiences of young girls like Tiresa, Amanda, and Saini in their respective villages, attest to how their lives changed with the arrival of the war. The sudden increase of soldiers in January 1942 disrupted the normality of life in small closely knit

\footnotetext{
${ }^{72}$ Hunter-Malietoa, interview.
} 
communities which had no control over the newcomers and the global forces that they represented.

\section{Disruption of cultural obligations}

One fundamental aspect of Samoan life that was disrupted by the war was access to resources that catered for basic physical and cultural needs. Samoan land usage was transformed during the war due to defense priorities. Land is the life blood of the Samoan culture. All aspects of Samoan life, including language, cultural practices, traditional economy and resources revolve around land. The interruption to people's access to land resulted in changes in cultural practice and social relations, impacting on Samoans' ability to fulfill their domestic duties and cultural obligations. This study argues that people's inability to access the core resources caused a transformation as people sought alternative routes and to improvise with the resources available. Saunia's memory of her wartime experiences is an example of this.

Our village [Fitiuta] decided not to have any of the usual village activities until the war finishes. The chiefs informed each of their families 'e nonomanu' - not obligated to contribute to village matters because the majority had no means to cater for the village and family obligations. Before the war, this village lived off the land and sea. They were our shops. There were not many plantations as well. However, during the war, no one was allowed to go anywhere. ${ }^{73}$

Wartime regulations and the fortification of the coastline restricted people from accessing food supplies and other resources required to live out their cultural obligations. The chiefs were well aware of the people's inability to fulfil their roles and had to call on their villages to '[faa]nonomanu'. The normality of life was put on hold. As the war went on the situation got worse even though there was no actual fighting in Samoa.

The village mayor announced earlier in the war for each family to dig holes/caves and cover them. These were for us to go into in case the enemy attack. We were not allowed to light any fires at night so we just sat in the dark and prayed. My father would sing a song with my mother to pass the time. The village mayor gave these orders that we, young girls used to be frightened of. Even our parents were afraid, especially when no one was allowed to go around in the night. I used to dread the night because it

\footnotetext{
${ }^{73} \mathrm{~Pa}$ au, interview. Nonomanu is to refrain from a usual practice to allow change to happen before returning to the previous practice. It can also mean waiting or praying in silence.
} 
was dark. We ate in the evening while there was still light. We were not allowed to light a fire. If we had a light we would cover it and not let it smoke in case the enemy aeroplane sees it. We used to eat bananas that were not cooked properly because we had to keep the cooking fire low. There was nothing to eat it with because no one was allowed to fish. ${ }^{74}$

The wartime restrictions had a significant effect on the daily lives of Samoans. Many wartime changes for Samoan women were brought about by the need to adapt to the regulations that confined them to 'caves' for the most of the day. Saunia's reminiscences draw attention to the disruption of the local food supply in remote areas and the privations that her family experienced. With a smile on her face, she remembered how frugal they had to be.

It was quite funny sometimes when you think about it. We could not go anywhere really, especially at night. You are not allowed to visit other families' caves. And if you want to send a message, there was nothing really to write with. We had to call out the pulenu'u to come so we can ask him if he can go to the next family to look for food because there was nothing to eat because there was no fire. If they find fire in your family's cave, the head of your family gets punished. We all had to endure it. As a young girl I wanted to run away, I didn't tell my parents really but that was always at the back of my mind. At that time you don't really see anyone visiting, it's normally just your families. They usually come up to check and do a head count in the hole. And if there is anyone missing then they choose younger men to go and look for them. ${ }^{75}$

Sauni'a's endurance of life in the 'aga-cave' remained an indelible memory of her wartime life. The initial excitement when the war arrived was replaced with frustration which caused her to want to run away. But Sauni'a was not alone in her fears. Many other young women shared her frustrations.

\section{Finding a different route to resources}

In Natives and Exotics, Judith Bennett has considered how military campaigns of the war affected the island environments. In her analysis, Bennett personifies the Earth as an actor which the wartime sojourners attempted to use for their own purposes. ${ }^{76}$ Bennett emphasises the war's lasting impact on the environments that the islanders had to live in after the war. The spiritual connections of the islanders to their land and environment

\footnotetext{
${ }^{74} \mathrm{~Pa}$ 'au, interview.

75 Pa'au, interview.

76 Bennett, Natives and Exotics, 305.
} 
were also often ignored. Military installations such as naval guns, pillboxes and wire fencing transformed the coastline of American Samoa, making it look like an island under siege. The military installations changed the features of the land. Amanda remember how the fencing regulated people to take new routes to access resources or to visit friends and families.

Leone turned into a beach chiseled with pillboxes and wires that changed peoples routes into the village - ua ta alofa lava i le matou beach i nai tagata - I really felt for our beach and our people. There was all this wiring! [Signalling the height of the wire fence and the rows], one, two, three. No one could get through, even the Japanese I guess. The fencing went all along the coastline up to the Leone Bridge. Everyone had to go through the bridge because that was the only way in or out. No one was allowed to swim or fish. There was no more of those big village fishing that we use to do. It was only after the war that we began again and there was a lot of atule, young mullet. ${ }^{77}$

Other villages on the northern side of Tutuila like Vatia were transformed in a similar way.

Vatia's coastline was hedged in with barbwire fences and pillboxes at both ends. It was an unnatural sight that the villagers had to live with. Although the fortifications might have protected the people from a direct attack, they restricted villagers' access to one of their main resources. 'E fou i le matou vaai! It was all new to us. We just watched the put up put up the fences. Ua si'o atoa ai le sami o vatia i le pa uamea. The whole coastline of Vatia was all fenced. ${ }^{78}$

Vatia women, according to Tiresa, were great weavers and are known for producing good quality Samoan mats and other handicrafts. To produce such quality mats, the pandanus had to be soaked in seawater for a period or buried in mud to dye the leaves. This part of the preparation for weaving specific types of mats became difficult. The heavily fortified beaches pushed the women of Vatia to find other areas to continue their traditional practices. Those who were most affected by these fortifications were the women and young girls. Everyday tasks such as fishing the lagoon for shellfish and other seafood stopped.

\footnotetext{
77 Iuli, interview.

78 Fiti-Brown, interview.
} 
While they were barred from accessing their resources, they watched the marines destroyed their fringing reefs to make way for their machinery. Tiresa vividly remembered that this was also the first time they saw the use of 'faga ia - dynamite' to blast the reef and allow bigger boats to come close to the shore. However, this development, as Tiresa put it, brought a new way of dying. Some villagers may have gazed in awe at the power of such a small device to deliver a mighty blow as well as it deadly potential when it claimed the life of a villager attempting to use dynamite for fishing.

The dynamite exploded and killed a man from my mother's family. He lit it using a taume (dried coconut branch) he thought it did not light because there was no flame from the taume. So he blew on the taume again and lit and it exploded and his hand came off. He went up in the air and came down into the water. What did we do, because those were the days of the maligi. We all sat down and looked at it. There was so much blood in the sea. We just sat and watched - ualeai se tala ua toe faia - no one could say anything. The wife came for her husband with a cloth to wrap him and to bring him out of the water and lay him down on dry ground. The maligi people came and they say to take him over the mountain to see the medics. He has to be carried. So the people brought the wood and a moega maligi (stretcher) and they put the man on it and tied him up so he doesn't fall off. They also got some bamboo and they put it through the stretcher and he was carried like a pig. Another girl and I had to go and carry the water for the dying man. I give him water when he goes iiisss, iiisssss [gasping for air]. That was the sound he made when he wanted to drink. We took him to the hospital and they said there is nothing to be done. The man died. ${ }^{79}$

The long arduous journey over the mountain ended in tragedy. Witnessing such a tragic event traumatised Tiresa. The incident took a turn for the worse when Tiresa was told to return to the village with another woman to ask the village to light up the way so they could bring back the body. Tiresa had a phobia of the dark and refused to do as she was told.

They beat me up but I was like a rock. I did not care. I am always afraid of the dark. I did not want to come, just the two of us in the dark. I couldn't do it. They gave me a hiding for that. There were no telephones then. The hiding they gave did not budge me, yes! So some of the chiefs who were with us came back instead. I did not care about my skin but as long as I

\footnotetext{
${ }^{79}$ Fiti-Brown, interview.
} 
don't go in the dark. So in the end we begin to see the lights in the dark coming towards us and we followed them. Those were difficult days. ${ }^{80}$

Witnessing the accident that claimed the life of a fellow villager sent a strong message to the people of Vatia about the danger of some of the material that was now accessible through the GIs. On the personal level, Tiresa's experience demonstrates that everyone was experiencing their own personal difficulties, like the phobia of the dark. The war circumstances intensified these personal suffering and fears to avoid being a nuisance to the family and the village.

\section{Villagers' Displacement}

Villagers were displaced from their land to accommodate military routines and installations. The marines' set up camp very close to Samoan homes at different villages around American Samoa. Villagers were told not to go into the bush anymore and to find somewhere else to move to because the marines were using the plantation lands for training. Amanda was anxious about where her family would live since the marines had taken her family's homes. The normality of daily life was disrupted and living space became very limited not only for her family but for the rest of the village.

All of the Leone people moved away from the village up to the togavao jungle/bush. Some went to Au'uma where the stream is, where the families quickly built about four faleo'o - small huts - for themselves. We went to a place called Auta at Malaeloa. It was far. The houses in the village were empty; only one person of the family would come to check on the houses in case someone steals the mats. ... We were upset because we wanted to come back to our house. It was always dark at night. ${ }^{81}$

Building faleo'o for families' wartime accommodation was a common scene in American Samoa at the start of the war. Young people like Amanda were unaware of the high-level arrangements between the government and the elders of the village that allowed the marines to invade and occupy family lands without their permission. This greatly distressed her family and reminded them of previous sad experiences.

I was afraid in the beginning. We were all asleep early one morning and were woken by a Catapillar (Backhoe) scuttling directly to our house. We all sat up and looked. It came so close to the side of our house that for a moment we said to ourselves, 'Auoi ta fefe, nei tei ua lavea le tatou fale! -

${ }^{80}$ Fiti-Brown, interview.

${ }^{81}$ Iuli, interview. 
Oh no our house will be demolished'! I was so scared and shocked at the same time. I was 16 when that incident happened. I was shocked. I thought it will crash into the big Moso'oi tree as well but it didn't. It was pulling something like a big tank. And there were a lot of marines standing around. They were not even bothered but for us it was the opposite. We were all frightened. We just sat there waiting for it to come back but it didn't. Ua ou tei lava, ua totolo mai lava faapea o le a taia i le Moso'oi tele ae e leai, e alu atu a ia alu. ${ }^{82}$

The voice of the village cryer, whose task was to warn people about the marine's activities, was drowned out by the noise made by these new machines as they bulldozed the area within the vicinity of people's homes.

Our village mayor was the only one who does the heralding to inform people about what was going on. At the time, he often called out 'fa'amolemole e faofale tagata uma, e sa se isi na fealuai, leaga e iai mea a maligi o loo fai - Please everyone must stay inside their houses and no one is allowed walk around because the marines are doing their work!' We did not even know what work it was because the mayor was a Samoan, he did not know what to call what was going on. But he calls out these warnings for us. So, we would just sit inside and not do anything but talk amongst ourselves about how overbearing and arrogant these people were because they dug up our land without talking to us. We did not know they were there to protect us. ${ }^{83}$

Amanda's narrative highlights the notion that the Samoans were locked in a situation that they were unable to control. The war was beginning to impinge on village activities and the cultural processes. Most of the families left the village and stayed in temporary dwellings on their other lands that were not allocated to the marines. This greatly affected village women's agency, especially in terms of guiding and enforcing rules about behaviour as set traditionally by the aualuma. But Samoa by 1942 was packed with soldiers and in some villages, like Leone, people lived far apart from each other, making communication difficult. In some villages, the village women's groups such as the aualuma and faletua ma tausi became inactive for much of the time and met only when it was necessary:

E lei fetaui le aualuma - the aualuma did not meet. Even the faletua mat tausi, it was the same. My mother who was a wife of a matai stayed home and kept our faleo'o clean and ensured there was always food for us. If ever there was something that these groups needed to discuss, it was at the

${ }^{82}$ Iuli, interview.

${ }^{83}$ Iuli, interview. 
church at Siona after the Sunday service or at the pastor's house they would meet. Sometimes it was at the Catholic Church, inside the cathedral that is. Because the marines occupied the parish hall. Everything was a mess then. There was another palagi who lived by the church in a palagi house. The catechist had to ask if the priest could live there during the war because marines have also occupied the rectory. ${ }^{84}$

As a result of the wartime circumstances aualuma matters were discussed in the church without any objection from the church. This shift in social boundaries, which were often strict during peace time, indicates that social restrictions could be flexible as safety valves that could accommodate human experiences.

The lapse in the activities of the closely connected women's social groups also meant there was also a break from the weaving groups and other group activities that contribute to women's socialization and learning of skills. One of the interesting developments during this wartime break was the formation of temporary groups, usually small, which replicated the functions of the aualuma. Amanda referred to this group as 'o le latou tama'i aualuma - their little aualuma', suggesting the group was created to serve a purpose for a short while before it was dissolved.

E lei faia se aualuma ona e lei toe feiloai lava tagata - the aualuma did not happen because people hardly met. But it was in 1944, that a palagi, an officer came and some of the older ladies gave him the title of Moso'oi Pala - Rotten Moso'oi [a reference to older women, as opposed to Moso'oi pula - Ripe Moso'oi usually associated to the young unmarried women]. He was their friend. They met over at Ilaoa's house, where they slept and sang. One of the girls was made a nominal taupou. Well she is not a real taupou. But they [the group] made her the taupou. It was Maliana Tuitele. The palagi came and stayed at her house. They were entertaining this palagi and other people one day while I was playing marbles outside. This was during the war. And the officer said to the ladies that he came to find the most beautiful girl at Leone. My eldest sister, Pulotu was part of that tama'i aualuma, not me. I got up to go and he called out from that group that I was the most beautiful of all the rest. He did not pick any of the group inside. Ha ha. I got five dollars. I stood there, my friends were asking me what the man was saying. We didn't bother what he was saying, we got money and left. Pulotu and the others were still inside singing. One of the blind old ladies here at the village had a granddaughter called Aveolela (Rays of the sun). These ones called their aualuma, Aveolela [Rays of the

\footnotetext{
${ }^{84}$ Iuli, interview.
} 
Sun] and gave the palagi the name often referred to older women. It was funny! ${ }^{85}$

Amanda's story about the Aveolela may explain Keesing's observation about the increase in the number of taupou titles during the war. ${ }^{86}$ What is significant here is that the group of women imitated the aualuma by appointing a nominal taupou and an aualuma for a specific purpose, which was to entertain the officers. This would not have happened during peace time. However, with the war on, the young women saw an opportunity to have some fun and created a group with the knowledge that they would not be ridiculed for it.

From their houses without walls, the Samoans observed and were fascinated by the daily military routines and the equipment. They watched the marines at work and in their leisure and saw how their lives were different to theirs while at the same time sharing living spaces with them. At times, many villagers felt sorry for the marines because of the strict military codes that dictated their movements:

Those poor marines were like slaves! What I mean is, that they did not sit around to evaeva [have a real down time] and be idle. It's only when they had their day off; I think it's about eight hours or so. But when they come [from the bush] they clean their guns, they would do this and that chore and clean. I always see that. Naughty Florida went over to have a look at how they cleaned their weapons and say to them, 'let me do it!' She wanted to clean the guns ha ha! But the guys said no in case she might get hurt. All of them carried guns and e le malolo! -They never rest! If ever they get a time out they would come here and hang out, but they were always keeping time (pointing to the wrist) Talofa e $!^{87}$

These trifling emotional connexions in such congested spaces sometimes set the tone for the relationships that developed between the Samoans and the marines. As occupiers of the same shared spaces, many young women witnessed and became active participants in the process of social transformation. Gathering venues such as mess halls and entertainment centres on family lands were visible from the home and the new activities captured the attention of young people and drew them in to participate.

On Saturdays, they [the marines] have what was called the Battalion Drills. Oka! We all went to watch it. It was nice. When we come back [to the

\footnotetext{
85 Iuli, interview.

${ }^{86}$ Keesing, "The Taupo[u] System of Samoa a Study of Institutional Change."

${ }^{87}$ Iuli, interview.
} 
convent], we imitated and copied all the English words we heard. There was a girl who was a comedian; she was the one who was the commander calling out, "Rear, to the Rear, March! About turn!" Like the way the marines did it. The nun was shocked with what we were doing; there was about six or eight of us doing this parade. It was Maselina Leota who was brilliant at those calls. After that, everyone clapped and cried that we have done this. Even the priest who was a French man was cheering on and saluted to us. We liked it because we learned many of those words and routines about marching. Some of the marines were listening and watching and laughing at us. Then we would always end with 'You are my sunshine.' Even the little kids knew this song by then. ${ }^{88}$

These lighter moments of youthful banter unconsciously wove the new changes and experiences into young girls' lives. Imitating the marines' parades helped them understand military terms and routines. Amanda described how the Saturday Battalion Drills and parade took a life of its own as the young people imitated them at the convent for all the neighbourhood to see. This behaviour normalised some of the new practices and integrated new ones, including their understanding of military vocabulary. Their emulation of the marines' routine was a subtle part of the changes taking place.

The arrival of the war was an epic event in the lives of Samoans. The sheer size of the military forces was unlike anything seen before on the Samoa islands. As seen in the village scenes described by the young women, the war regulations restricted, displaced and disrupted people's lives and their cultural practices. Young Samoan women's wartime experiences reveal the extent to which the war changed their lives. Such change was beyond the Samoans' control.

Young people were fascinated by the new sights and sounds of so many young foreigners, and huge machinery and new colours. But when the euphoria subsided and they found the ordinariness of their lives was challenged by the new wartime circumstances that they had to negotiatein their daily lives. There was no time to reflect and consider the depth and long term effects of their responses. All of the interviewees I have referred to in this chapter saw their families and villages changed in response to the wartime situation.

Samoa's colonial status influenced the timing and the character of the transformation. Both administrations flexed their authority through the use of regulations, but both

${ }^{88}$ Iuli, interview. 
ultimately had to defer to the US military command. It seemed as if each of the territories had two different sets of authorities, colonizing the territories twice over. Although there was no actual combat in Samoa, people were still displaced and this disrupted daily routines, causing change and adaptation. At times, personal priorities were put aside. Samoan women engaged with the war by cooperating with the regulations that hindered their independence while at the same time they made choices and adapted their cultural practices to suit the new circumstances. Samoan women's roles in their families and communities epitomise the notion that transformation is caused by the mundane business of ordinary life. Little by little, the Samoan women and the rest of the Samoan population adjusted their lives according to the tune of the regulations and the troops that occupied their space. Women helped each other cope with the changes. The wartime conditions did not allow them the luxury of time to find better solutions than the ones they came up with during the war. At times, as highlighted by Saunia, doing nothing was the best response. 


\section{Chapter Four. Samoan Women and the Churches during the War}

This chapter triangulates the Second World War, Samoan women's agency and the Christian churches. A close examination of these three elements highlights the important ways in which they intersected, creating avenues that expanded and rejuvenated the scope of Samoan women's agency which had been marginalised and narrowed by Christian influence. At the same time, the war heightened the existing tensions between Samoan women's agency and the power of the churches. The churches provided spaces in which American troops socialised with Samoans, creating social situations that were difficult to control. Some wartime experiences had little to do with the war but were life changing experiences nevertheless for some individual women in relation to the churches.

The chapter begins by exploring the military "occupation" of church spaces and the changes which resulted. The discussion then focuses on the experiences of individual women in relation to the churches and their views of the churches during the war. Their accounts underscore some of the powerful elements of the wartime relationships between the churches and individual women.

\section{The Churches and Wartime Change - the occupation of church space}

The war brought a different dimension to the Samoan women's relationship with the churches. Before the war, the church was a social force akin to the colonial administration. But when the emergency regulations were activated and the US military command took control of the entire Samoa Defense Group, the churches, like the Samoan parishioners and the colonial officials as well, had to answer to a higher authority. They had no choice but to conform to the military demands on church premises. The US forces occupied significant properties such as the LMS Malua theological college, the Catholic seminary at Moamoa and the Methodist headquarters at Faleula. $^{1}$

On the island of Tutuila, the newly established Mormon agricultural school at Mapusaga was quickly filled by the GIs. The Catholic rectory and the convent buildings at Leone

\footnotetext{
${ }^{1}$ US Naval History Division, "US Naval History of Western Samoa," Micro-MS-0850-1, ATL.
} 
housed the officers while enlisted men were accommodated in village homes and in canvas tents pitched in the open spaces. Amanda tells how the rectory became an administration building for the marines while St. Theresa School became an ammunition store. ${ }^{2}$ The only priest had to move into the home of a village family after some of the chiefs pleaded with the military authority to keep a priest in Leone.

Bishop Darnand wrote to Father Fotheringham in American Samoa, immediately after the United States declared war against Japan describing to him some of the initial changes the church in Western Samoa had to make to accommodate the unfolding situation.

I was anxious to get news from Pago Pago. People coming back to Upolu tell us everything and explain about the precautions taken in your American island. But your letter shows that you are still all alive. The sister's school in Savalalao is now a dispensary and Moamoa an Emergency Hospital. The crypt of our church is full of cases, beds, packages. Eight Samoan houses in Vaea have been taken to receive the sick and wounded. Black outs in Apia and Moamoa. No midnight mass this year. ${ }^{3}$

Darnand's letter clearly shows the changes forced on the churches with the advent of the war, altering the functions and role of the church, from a space of spiritual calmness to military stores and barracks. Like their parishioners, the Church authorities could not do anything else but abide

Although the churches generally conformed to the wartime situation, tolerating the military attitudes may have strained their relationship with the authorities. For example, President Emery of the Mormon Church Mission refused to vacate his mission home at Pesega. Emery's son later related how the tension was resolved based on religion and comradeship as fellow Americans: 'As things turned out the Commander, William McKean was a neighbour to my father and a member of the Ward where my father was Bishop for 25 years $\left(29^{\text {th }}\right.$ Ward - Salt Lake State). Commander McKean assured my father that they could get along without the Mission Home'.

\footnotetext{
2 Iuli, interview.

${ }^{3}$ Bishop Darnard to Fr. Fotheringham, 17 December 1941, Oceania Marist Province Archives (hereafter OMPA), Reel 67, ATL.

${ }^{4}$ Harris, Building the Kingdom in Samoa, 73.
} 
The military occupation made the churches sites for various encounters between parishioners and the marines. Churches, school, rectories and the homes of ministers and catechists are all considered as church spaces in which a variety of encounters occurred. For example, the rectory at Leone housed officers while the priest was housed with a local family. It remained a house from which authority was dictated. It was also a place where some young women met the officers they befriended. Amanda reveals, for the first time since this incident occurred, an experience that almost ended in disaster for her and and her friends Apolo and Ruby.

Ruby's boyfriend was an officer at the Rectory. Only I and another girl of our choir knew about it. So we were always in good terms with Ruby. One of us had to go upstairs to give the message to the boyfriend if we wanted to go for a ride in the jeep to Amanave. There were MPs (Military Police) we had to avoid. Apolo went to give Ruby's message to the officer who called out, 'Mr. Palmer, Ruby wants you to come.' He came down, brought the jeep, and we got in. Ruby went to the front. One of the girls was scared and opted not to go. So it was just Apolo and I in the back. I have never told this to anyone before. We went all the way past Amanave heading up to Poloa. The road was slippery as it started to go up, speeding at the bend and the jeep went straight to the breadfruit tree on the side of the road. It was God's grace that saved us! We were literally on the breadfruit tree which came up from the side of the cliff. That was the only thing protecting us from going over. The man [Mr. Palmer] told us to get out of the jeep. Some of the young men from Poloa who heard the booming noise when the car hit the tree came to help. They shamed us first, Ua omai faama matou! They helped lift the vehicle back on to the road. There was no flat tyre, so he turned the car and drove back home. No MPs came as well. We were lucky. They dropped us off (Apolo and I) and continued to the rectory. The priest did not know that Ruby always go upstairs with the palagi. I did not tell anyone because I was scared in case my father finds out. I was supposed to be at the choir practice then come home to sleep. Ha ha! When I see Palmer, he always says 'hi.' Some of us when we want to speak English, we would call out to them, 'Hi officer!' Alternatively, we would say, 'Hi Lieutenant!' There were many of them [officers] at the Rectory, they had pins, we did not know about the differences in the [army] pins because they just got here. So it was always best to just call them officers. Leone had many houses used by the troops. Even the (LMS) missionaries' house at Fagalele, they had to leave, and the army took over that house. ${ }^{5}$

Amanda was thankful that they all lived to tell the tale of their adventure with the officer to Poloa. The rectory was a place that was normally reserved for the priests and

\footnotetext{
${ }^{5}$ Iuli, interview.
} 
other members of the clergy. It was a restricted space for men. But as Amanda revealed it was also a place that they could access discreetly through their friendship with certain officers. There seemed to be an ease in the way the young women related to the new tenants of the rectory compared to their relations with the clergy. Amanda also highlighted the point that the missionaries, both Catholic and Protestant, had to move away when the military took over. The church authority at the rectory was replaced by the military. To the young women like Amanda and Ruby, the new authority changed the dynamics of what the Rectory represented, making the building more accessible to them.

Many other types of relations were fostered within the churches between the marines and Samoan women and this was one of the reasons why they frequented the villages and many Samoan family homes. Marines penned in their diaries their appreciation of the home cooked meals some families offered them. ${ }^{6}$ Sivao remembered cooking a meal for her sister, Joyce, who asked her father if she could invite some of her American GI friends to their home:

My sister Joyce had maligi friends. She asked if I can cook a meal for them and I did. I made fried steak, potatoes mash, gravy, and the dessert was apple crumble. The marines thought that we didn't know how to cook that kind of meal you see. But we did. One of the marines asked Joyce about who cooked the meal and she told him it was her sister that was me. And they said it was great. They had seconds and thirds. They were all happy about it.

Ana, Tiresa, Faasalafa and Isabella all say that families looked after the marines: 'E tofu lava le aiga ma le latou maligi.' Most of the marines were young and were missing home. Sr. Makerita while she was still a student at Moamoa, recalled that her school was used as a store for all the US Soldiers uniforms. As a student, she talked with some of the soldiers who were not much older than her and who were missing home. Some of them showed her pictures of their wives, girlfriends and even the children. 'E nai tamai mea lava, masalo e 17, 18 - they are very young, perhaps $17,18{ }^{8}$ In some cases the wives of

${ }^{6}$ Marbaugh A Journey with the Marines.

7 Williams, interview.

${ }^{8}$ Leauna'i, interview. 
the pastors and catechists and older women played a maternal role for the marines. Amanda relates that:

A young marine went out to the bush and found a little pig in the fox-hole. That was a new term we learned from them. He came back and gave it to the catechists (Veronika and Petelo) whom he referred to as Mama and Papa, to look after. The pig was named Gunda! And they took really good care of the pig as well as the boy. When it was time for the boy to return (to America), Veronika put up a feast for him. He cried saying that he was going to miss them. Veronika cried and hugged him. What happened to Gunda? I think we ate it at the farewell ha ha!'

Caring for the marines was a theme that resonated in the oral histories collected for this research. It shows how women's roles extended to accommodate new people. Women are the stronghold of the family in their roles as homemakers and as nurturers who look after the family and newcomers within the church.

\section{Disruption to mission school routines}

The disruption caused by the arrival of the troops affected not just the buildings, but missionary work as well. The Mormon Church had evacuated most of the missionaries who were working in Samoa by 1941. Heads of church missions in Samoa had to write to the local authorities for permission to allow missionaries to come to Samoa during the war. The frequent denial of these requests disrupted church development. ${ }^{10}$ The Mormon Church for the first time selected a Samoan to look after the Tithing when the missionaries had to return to America for the war effort. ${ }^{11}$

In American Samoa, schools closed from the end of 1941 until the end of $1944{ }^{12}$ Amanda related that 'Sa nonofo uma i le fale le autalavou - All the youth stayed home. Some of the older boys joined the Samoa marines. ${ }^{13}$ Many young women thus experienced the war away from the direct influence of the church schools, and this had a bearing on the level of their interaction with the troops. Young women who studied at Atauloma went back to their villages to either the church minister's house or their family home to help. Others, like Saini, joined their friends at the aualuma. Most

\footnotetext{
${ }^{9}$ Iuli, interview.

${ }^{10}$ Mr. W.S.M. Organ (Seventh Day Adventist Mission -Apia) to Mr. Quin (Department of Internal Affairs -Wellington), 26 November 1942. ACGA 8280 IT 431 EX69-151 Part 1, ANZ.

${ }^{11}$ Harris, Building the Kingdom in Samoa, 1888-2005.

12 Iuli, interview.

13 Iuli, interview.
} 
aualuma around American Samoa were only semi-active because families moved away from their homes while the marines occupied the villages. Young men who were of working age either joined the construction labour forces or the Samoan marines or worked as mess boys at the various Mess Halls.

Papauta School continued to operate at the beginning of the war but eventually closed as the number the US troops increased. On the other hand, the Catholic schools in Western Samoa continued to operate during the war. The sisters opted not to be evacuated, despite being on Turnbull's list of evacuees and despite appeals from their families to return to Europe or New Zealand.

Regular evacuation drills were a disruptive wartime routine added to the mission schools' program, causing anxiety amongst young students. Alice remembered that there were always warning sirens for which everyone had to stay inside the classrooms.

We were all worried because every now and again we hear a siren. But for some reason, maybe something is going overseas or something. And when it went [while at the convent] we were all told to go inside, even school during the day, we hear the siren going, we were all told to go inside the room and wait until the end. You know when you hear the fire warning? Even when it's not happening there, or somewhere far, as soon as we hear the siren, everybody goes inside the rooms until it's finished and then when the siren go again then we were allowed to go outside. That was my only experience, but we do not see any action of anything else, nothing at all, that is all there is, just the siren. ${ }^{14}$

Alice's description of how the sirens dictated their lives also illustrates the level of local understanding about the war and the connections between local and international events. However, the Savalalo students were not the only girls' subjected to these wartime routines. Isapela, a sickly young student, remembered how difficult it was for her as a student to cope with the regular evacuation drills at Papauta before the school closed for the war. War evacuation procedures became part of school life for young women under the care of the churches.

There was a stream at the bottom of the valley, behind the church at Papauta School. Teachers instructed us that if ever the school is attacked by war troops, we should all escape to the valley to hide. So I usually hang about in front of the church in case there is an attack then I will be one of

14 Alice Mary McElhiney, interview by Louise Mataia-Milo, Saturday, April 4 2014, Manurewa, Auckland New Zealand. 
the first to escape because there were many of us and the route down to the bottom of the valley is steep. My leg also had the mumu - the red. I usually try to slide down on the side to get down to the river. We were told if we see an aeroplane coming we should all run to the valley. We had these drills every Friday. A lot of the girls got tired of doing this all the time, so they ran away. ${ }^{15}$

Another change seen in the church schools during the war was the increase in prayers for the war, especially in the Catholic schools. Isabella remembered that from 1942 the whole school was always praying and this did not finish until the war ended.

The rosary was always prayed to stop the war. The whole school. We start school in Savai'i at eight finish at 2. Then it shifted to start at 9 and end at 3. At that time we always say the rosary and prayers for the war. At the time the nuns told us to pray that the war doesn't come to Samoa or to end the war. All I remember that we always pray a lot of rosaries But at home, we do not because we were already $7^{\text {th }}$ Day adventists by then. ${ }^{16}$

What Isabella did not know, was that she was united in the same prayer with all other Catholic children and missionaries round the Pacific. The Marist order in Oceania province sent out a request for all the missionaries to pray the rosary during the war to seek 'divine remedy [for] the terrible crisis that our Marist missions in the Solomon Islands [face]. ${ }^{17}$

When the US forces converted the Malifa and Leifi'ifi schools into military barracks, some of the girls from these two schools opted to move to St. Mary's for the commercial training courses that had begun there before the war. Sister Patrick coordinated the commercial training courses during the war, preparing a special generation of women who were in important positions as secretaries in the political negotiations leading up to independence. Winnie Laban reminisced how her mother, Analyse Patu of the village of Vaiala, was one of Sister Patrick's former students who had fond memories of the importance of her training from St. Mary's during the war.

One of my mother's memories about the value of the education she got from the sisters were the skills she gained that gave her a job in the government. She said that she was one of the secretaries who were involved in documenting the processes and procedures that prepared Samoa

\footnotetext{
15 Malautea, interview. Mumu - red. This is the common name for the disease of filiariasis. The affected part of the body swells and become red.

${ }^{16}$ Isabella Stehlin Ryan, interview by Louise Mataia-Milo, 7 May 2015, New Lynn, Auckland.

17 Oceania Superior Order to Bishop Darnand, September 1943. OMPA reel 63, ATL.
} 
becoming a nation in the 1950s. She typed the founding document of the country - the Samoan constitution. But she credits the sisters for that. ${ }^{18}$

Analyse's intimate connection with the Samoan founding document illustrates how women contributed to political developments; an involvement that was made possible by a relevant educational experience. These are women's political contributions that are overlooked in Samoa's narrative of nation building. Analyse's and other secretaries' contributions are significant historical events.

As mentioned in chapter 2 some of the new sisters sent out to the Samoa Islands before the war were Americans. They befriended the US marines who in turn could sponsor some of their students. As related by Sister Consolata in her memoirs, at times a marine would turn up to school to request a place for a girl whose family the marine had befriended. This may explain a slight increase in student numbers at the Convent school at Savalalo in the early 1940s. ${ }^{19}$

\section{New Worshippers}

The church was a familiar space to the marines and reminded them of home. Sunday, as a day of rest and church services, was observed by the marines. Nanati saw during the war that 'on Sundays, they do not work or walk around like the week days. They just sit around quietly in the morning. They were told about the importance of Sunday so they don't do any work but just rest and relax around. It's only during meal time that you see them in a long line [to the mess hall], ${ }^{20}$ Catholic marines attended the Sunday masses which were all in the Samoan language at first. With the marines' presence services soon became bilingual. Some marines requested the regular celebration of the mass. The priests tried to accommodate these requests, but found themselves overworked and had to write to the bishop for permission to celebrate more than two masses a day.

Fotheringham sought Darnand's permission to celebrate more masses but Darnand replied that, 'Rome can only allow three per Sunday' and thus the services were kept at this number. ${ }^{21}$

\footnotetext{
18 Winnie Laban, interview by Louise Mataia-Milo, 22 Feb 2016, Kelburn, Wellington.

${ }^{19}$ Sister Mary Consolata, Samoa with Love.

${ }^{20}$ Savusa, interview.

21 Darnand to Fotheringham 4 August 1942, OMPA reel 67, ATL.
} 
The churches overflowed in some parts of Samoa, but this was not the case everywhere. Places such as Leone, Fagatogo, Pago Pago, Apia and along Satapuala had more marines attending local churches. By sharing the same space with Samoans as Christian equals, many of the marines developed connexions with the local population. A marine from Boston described in his published memoirs his memory of going to church in Samoa:

Sundays was church day and everyone went to church. The women showed up in white dresses and parasols, and the men wore white suits, a white shirt, and no tie. Many men wore large white "planter type" hats. I never could see a place in their fales where they could have stored these sparkling white Sunday go-to-meeting clothes. The church service was first in French, then in Samoan, and then in the most fractured English I have ever heard. This tiny church was ancient with a rock floor and of course, a small bell tower. There were no pews but they did have some antique portable, wobbly, wooden bench seats just big enough for four people to sit on uncomfortably. There were many tip overs when people shifted their weight. All during the service the bats and birds that lived in the bell tower would fly around the ceiling. When the Samoan women started to sing, high pitched voices all in unison and loud, the birds flew around scared into flight by the noise. ${ }^{22}$

Carey's memoirs show the humble physical sites of the church and the exchanges that took place between the women and men.

In his assessment of Samoans' military work Franco suggests that material gain motivated Samoans' relationships with the marines. ${ }^{23}$ However, Samoan women's wartime experiences show another dimension to the relationship. According to Sister Makerita, "We talked with them when we went to collect the coconuts and found out that some of them were just boys, far away from home. ${ }^{24}$ In a small society one quickly learns the reciprocal nature of the culture. Perhaps the flash lights, guitars, and comics and even money given to individuals, were tokens of appreciation and camaraderie rather than payments. More of these exchanges are discussed in the next chapter. However, what is important here is that women extended their roles, even within the church, to help the marines cope with their situation.

\footnotetext{
${ }^{22}$ John J. Carey, A Marine from Boston. A First Person Story of a US Marine in World War II: Boot Camp, Samoa, Guadalcanal, Bougainville (Bloomington, Ind.: First Books Library, 2002).

${ }^{23}$ Franco, "Samoans, World War Two, and Military Work"; Gray, Amerika Samoa.

${ }^{24}$ Leauna'i, interview.
} 
On a different level, the church was a neutral space where women and the marines could interact on an equal footing. Here the interactions were more of a social nature, helping to bridge differences between the two people. The view from this standpoint showed the humanity of the machine of war as many young men were missing their families. Amanda was surprised to see the marines crying.

It was Christmas and they [the marines] all wanted to attend church service. Most of them [in Leone] were Catholics. The Naval Officers lived at the Rectory. The priest had to ask them for a candle to use for the midnight Christmas mass (blackout curfew still enforced). It was really nice in the old cathedral. The walls were high with only one entry onto the main road. So we lit the candle and the priest who was French led the mass. I was in the choir. Gapo (the choir master/conductor) took out a little light he got from a maligi for himself. It was the first time to see a little [flash] light. We all sang in the dark because we all memorised everything in Latin anyway. That is the Samoan way. The church was full of maligi. I said to Gapo that I know how to sing the song 'God Bless America'. I knew it from the nuns. He told me to sing the song and I did. At the same time, he was playing the piano, trying to find the tune for the song. He was good at that. Just when I was about to finish the song I hear someone wailing. Yes, it was the end of the Mass. They were the maligi boys around 17 years may be, all crying! They did not want to go outside. They just sat inside and cried missing home. $^{25}$

Unbeknownst to Amanda, she had contributed in the already energised call to arms, reminding the marines of their homeland. Amanda was an agent of wartime change. Her rendition of this American patriotic song during the mass was an unusual event. Soldiers were supposed to be strong minded and disciplined with their emotions. However, at Leone, Amanda and many of her fellow villagers saw not soldiers but young men missing home. The only thing to do was to help them out. A similar incident also occurred in Apia to Alice who was punished by Sister Mary Theresa, for breaking school rules to help a marine who needed help.

I talked to a soldier when I was at the convent. I was playing tennis at the front. Our rule was, you are not allowed to talk over the fence. You got to ask for permission before someone talks over to you. But when this truck pulled up, and the guy came over and asked me, [if] I have a medal of St Christopher. I had one so I went upstairs without asking permission to get my medal to give it to him. I know I was breaking the rule, but I didn't have time to go and ask for permission. So I was punished for doing that. ... On Friday and Saturday nights, during the roll call, they call your name and if

25 Iuli, interview. 
someone knows you did something wrong they will tell. Well the girls who were playing tennis, told the nun that I didn't ask permission to go and take the medal to this man. So my punishment was to kneel during the whole mass for a whole month, I don't sit down. That was my punishment. In fact I think it was a bit harsh. but I accept it, I went along with it, I know I was breaking the rule but if I go a look for permission I missed out on this guy who wanted a medal. ${ }^{26}$

Alice did not mind the punishment because she knew that she had broken a rule. However, to her, getting the St. Christopher medal to the marine was far more important than asking for permission.

[He needed the medal because he was going away] That is what he said. He knew this was a convent, it was the only place he could get a medal. And the truck was waiting there for that. And that was the reason I thought, if I go looking for the sister to ask for permission, they haven't got time to wait. There were quite a few of them [on the truck]. But this guy, I don't know, must be depressed, or needed it to feel better about it, or he is a Catholic, most probably otherwise he would not have asked for the medal. And then he stopped the car and he called and I went over and talked to him. ${ }^{27}$

In the Catholic faith, St. Christopher is the patron saint of travellers. The faithful often pray for his protection during long difficult journeys. Alice understood the significance of the medal and she went out of her way to ensure that the marine got the protection he asked for. These different examples and experiences show that although the space of interaction was at the church, the relations between the Samoans and the marines were a lot closer and different from those with the clergy who tended to separate themselves from the people.

In Leone, the priest having to ask for the candle illustrated the shift in the local balance of power where the US command now had sole authority over church routines. It perhaps also shows that the church too had loosened its grip on the order of service especially in the songs and hymns sung at the mass. The overwhelming emotions may have obscured the historical significance of this event that signalled a shift in attitude by the church and all those involved to accommodate the presence of the Americans.

${ }^{26}$ McElhiney, interview.
${ }^{27}$ McElhiney, interview. 


\section{Cash and the Churches}

Bishop Darnand saw the military occupation of the Catholic schools in American Samoa as a 'blessing in disguise', anticipating the transformation and improvements to the buildings that would be made by the government. ${ }^{28}$ Darnand's idea characterises the position of the churches during the war more generally. Cash earned as wages flowed from the military to the Samoans and into the churches. Darnand approved the purchase of a piece of land where the old Catholic chapel stood in Pago Pago for $\$ 700$ dollars in $1941 .^{29} \mathrm{He}$ also supported Fotheringham's suggestion to invest in war bonds. ${ }^{30}$

In Nu'u'uli, Nanati saw how the church services also became sites where wartime wealth could be displayed. Money earned by Samoans during the war led to an increase in parishioners' financial contributions to the churches. Before the war, the church produced copra to finance the churches' developments. ${ }^{31}$ This changed during the war; the cash brought in by the American troops ended up with the church.

The money came from the tamea, laundry! When Friday or Saturday comes, a maligi would turn up to your house with his washing asking the women if they could wash their clothes. When they come back to collect their washing and give you money. Oka ni tupe - wow it was heaps of money, like a 50 or 10 dollars! The women here had a lot of money. But the washings were small, maybe about two pants and a shirt. There was so much money, cash but people did not know what to do with it. Sometimes I see a $\$ 100$ dollar bill, it was too much. The toeaiina (older men) saw how crazy people were getting with the new cash. The pledges for the pastor became a competition on who donates the biggest amount. Some families who seldom afford to give money, they started to donate around $\$ 100$ dollars for the alofa. All of this caused by the money from the marines. One of the village elders who could afford to donate towards the upkeep of the faifeau, advised the new rich to 'faifai isi - take it easy.' The old man named one of his family relatives 'Faifai' isi' to commemorate the change he saw at church and in our village. The name refers to those families or people who were not well off in the beginning but when they got some money from the marines they immediately want to display it by donating a lot of it to the faifeau. I remember he said it at church when we were all there. And of course, the faifeau made a lot more money than everyone else. ${ }^{32}$

\footnotetext{
28 Darnard to Fotheringham, 3 January 1942, OMPA reel 63, ATL.

${ }^{29}$ Darnand to Fotheringham, 8 January 1941, OMPA reel 63, ATL

${ }^{30}$ Darnand to Fotheringham, 20 April 1942, OMPA reel 63, ATL.

31 Wendt, "Guardians and Wards"; Jocelyn Linnekin, "The Teacher and His Copra", 544-7.

32 Savusa, interview.
} 
The elders were concerned about the display of the new wealth and warned the families about the excessive giving to the church. The new money ignited a spirit of competition not only in Nu'u'uli but in many other churches around Samoa.

The war also brought a new type of fundraising for the parishioners of the different Christian denominations. Cutting copra was the main income for most of the churches in Samoa before the war. This time consuming and labour intensive way of earning money changed during the war. Raffles and socials were a lot easier to organise, more entertaining and generated more profit. In many cases the women were responsible for setting up these fundraising activities for their church. Regular raffles and socials in the villages, usually on the church lawns, fascinated many young people because it gave them something different to look forward to. The women were at the forefront in organising these events for the church. Saini remembered that during the war, the women raised funds to build the old church through monthly socials at the place where the church was later built. ${ }^{33}$ Here we see how the traditional executive role of Samoan women was put to use during the war to raise funds for the church. This illustrates the wider scope of the Samoan women's agency.

Several churches and schools were under construction, during the war. In the middle of all this fundraising and construction, the church authorities were reluctant to accept any criticism from the villagers. Bishop Darnand's attitude towards the Leone parish illustrated this point when he wrote to congratulate Fr. Fotheringham on 26 April 1940: 'Malo le galue - Well done with [the] work you are doing. I am glad to hear that you have finished the ceiling of your church. Too many 'teuteu' - decorations are useless. You were right to tell the people to open their purse more generously and their mouths less frequently. 34

Darnand's attitude suggests that the churches benefited a lot more from the war than the individuals who gave to them. The government of American Samoa was not blind to the church officials' drive to renovate churches and other projects such as bell

\footnotetext{
${ }^{33}$ Milo, interview.

34 Darnard to Fotheringham, 26 April 1940, OMPA reel 67, ATL.
} 
towers. In reply to an attempt to avoid paying import taxes for some of the material for the church tower at Leone, the Governor responded:

The governor is mindful of the service rendered to the Samoan people by the Catholic mission and by other Christian denominations but he is also cognizant of the generous financial support given to all churches by the Samoan people and it is only fair, therefore that the churches pay their just proportion of import duties and other taxes to the end that the hospital and other governmental services can be maintained for the benefit of the Samoan people. ${ }^{35}$

The naval administration knew that the money from war ended up with the church.

Exploring the churches and wartime changes reveals several things about the church that perhaps were not known before. The churches authority diminished during the war although it was still recognised as an institution that brought people together. Like the villagers, the churches too had to toe the line with regulations. Their premises were important to military logistics as well as spaces that brought the two peoples together as worshipers. Young girls like Nanati and Amanda saw during the war that the cash earned by their relatives flowed from the marines to their families who then donated to the church. The church earned a lot of money, indirectly during the wartime period.

I now turn this discussion to explore the wartime lives of some individual women and their experiences with the churches during the war. There were no specific wartime programs ran by the church to better prepare them for the arrival of the war. No one expected a force of this magnitude until it arrived. The church as a spiritual institution was expected to give spiritual nurture during such tumultuous times. The following examples show how women's wartime lives were influenced by the church.

\section{Lives Governed by Many}

A distinctive feature of women's lives in pre-war Samoa was the Christian churches' power and authority over almost every aspect and stage of their lives. By the 1930s the traditions which governed Samoan women's lives had been profoundly influenced by Christianity. Christianity was intricately integrated into the Samoan consciousness and cultural practices and had significantly narrowed the contexts in which Samoan women

35 Governor Captain H. A. Houser to Fr. Goupillaud, 11 October, 1946, OMPA reel 67, ATL 
could exercise their agency both individually and collectively. The church assumed a position of power akin to the traditional chiefly aristocracy whose endorsement legitimised the churches' authority in Samoan society. This relationship explains how the churches were able to exert their influence over people's lives and the culture. This status was an advantage to the clergy giving them the right to control and determine the life paths of Samoan women. The examples that follow from my interviews with Faapusa, Saini, Faanunumi, Amanda and Makerita demonstrate how their lives were influenced in one way or another by the churches.

\section{Faapusa and the church minister}

Faapusa from the village of Matavai in Savai'i made a sudden decision about her life after she was persuaded by her village minister at the LMS annual conference in 1942 to accept a marriage proposal from a much older pastor, a widower, when she was only 20 years old:

We were eating, and the church minister from my village called to me and said that I [should] go and eat with one of the men [the widowed pastor] in the front. After the meal, our minister said that I can talk with man, who was also a minister but a widower. We talked, and I refused when he proposed. $\mathrm{Na}$ ou faafitifiti ai i le tamaloa ona ua uma na fai lona toalua ao au ou te le iloa fai toalua ne'i tei ua fasi au - I refused him at first because he had a wife before. I did not know how to be a wife in case he beats me. But eventually, I accepted his proposal. Afterwards, I told our church minister that I accepted the man's proposal and we were married on the same day at the fono. We went with my church minister to where the Lefaga parish (the village in which the widower belonged to) were staying to present me [as the new wife of one of the church ministers]. My family only found out later when people told them. Then they came to do the Samoan custom for the wedding. But after the fono, I did not come back to my parents. I went to Lefaga and lived there as a minister's wife and only returned home when my husband died. ${ }^{36}$

Faapusa left her parents at Matavai only because the church minister asked her parents for her to come to help out at the conference. She agreed to it because she wanted to help out. Faapusa had no knowledge that her religious parents had other plans. She was in a position where she had to accept their decision, perhaps as a way to save face and she did not dare to disobey.

${ }^{36}$ Faapusa Faumuina, interview by Louise Mataia-Milo, 17 October 2014, Matavai, Safune. 
Faapusa's story of her experiences shows how institutional roles such as being 'spiritual parents' were used to accomplish clergy's personal agendas. The lives of young women, like Faapusa, became entwined with the plans of the village minister. For Faapusa, to have rejected the proposal would have meant disobeying the minister and this would have been disrespectful. One can argue that Faapusa was placed in a position where she could not say no and was forced to accept her new situation as 'her choice'. She had to accept her fate because of her duty to the pastor as her spiritual parent. Faapusa was naïve and did not understand the ways of the world. Moreover, this was her first trip away from her village and away from her parents who, according to Faapusa, knew nothing about any plans to marry her off.

As a single woman whose socialisation has been informed by biblical and Christian rules, Faapusa was anxious about her new situation. It is probable that Faapusa's experiences were replicated around Samoa to varying degrees. One of the common understandings entrenched informally by the church over generations is the notion that it is bad luck for a woman to refuse a proposal from a man of the cloth. This belief continues to be used today to threaten young women who refuse to conform to the church's bidding about marriage. There have been incidents where young women have eloped with someone because they disagree with the clergy's decision. In some instances women have committed suicide. It is also important to note that families also persuaded young women to marry men they did not like. Ana tells us that 'o lo'u toalua muamua, ou te lei manao i ai ae na ave lava au e le matou aiga faanofo ai, ai ona e faapea o le afakasi. - I did not want my first husband but my family pushed me to marry him, I guess it was because he was half-caste. ${ }^{, 37}$

\section{Saini Milo and the church minister}

Saini Milo also suffered a similar fate to Faapusa. Saini was born in Amouli, Ta'u, in 1926. She is one of the youngest of twelve children born to Sunema and Mauga, both from the village of 'Ta'u, the eastern-most island of the Manu'a Islands. Saini went to the local village school at Papatea where she learned how to read and write. Saini

\footnotetext{
${ }^{37}$ Savea, interview.
} 
recalled that her mother's advice was to live a virtuous life. It was the church, though, that governed her life's journey leading up to and during the war:

We had a relative who was a church minister who just returned from Leulumoega (Malua Theological College) with his wife. They just completed their studies and were invited to the village of Faleasao. He came and said to me, 'ua lava lena aoga - that is enough schooling.' However, I was only in Class 6 you see, so that was the end of my school years. We moved to Faleaso, and I did all the domestic chores for the minister. When it was time to select the girls for Atauloma, that was the time when Atauloma had already started; I was picked together with two other girls from Faleasao. So off I went [to Atauloma School]. ${ }^{38}$

The religious teaching to respect the clergy shaped Saini's early life. The church minister did not contemplate the importance of education for a young lady in the long run; he only saw her usefulness regarding domestic duties. The minister's authority to select girls to go to Atauloma and Papauta meant that he held power to influence the trajectory of young women's journeys and their futures. Saini might have hoped for a new beginning when she was chosen to go to Atauloma. However, with another arbitrary decision from the minister, her world changed when she was in her late teens during the war.

I came back from Atauloma for a holiday. The faifeau was at our house when two young men entered the house. The minister calls me into the house; he wanted to talk to me. I came in, and the minister said that I have to go and sit next to the young men, I did not know who they were then you see. I asked him, 'Why? I do not know them!' And the minister said, 'if I tell you to go and sit with them then you go!' The minister then turned to the young men and asked them for the reason why they have come to our house. The young man next to me spoke, 'I have come to ask you and your wife that I would like to marry your daughter - Ou te fia nofo i lou alo.' Ae e na o le sefuluiva ou tausaga ae faanonofo a a'u ma le tama lea e le faifeau. - I was only nineteen years old and the faifeau married me off to this man. I didn't know him. We were not together for a long time. He went off with other women. Ae o a'u na ou fia alu lava i le aoga ae vavao au e le faifeau e fai mai ou te nofo ona ua leai nisi o le aiga. - I wanted to return to school, but the minister stopped me, saying that I have to stay because there is no one to look after the family. ${ }^{39}$

The power of religious persuasion influenced Saini's decision to accept a stranger's marriage proposal. Saini did not desire the life she ended up living, but she did not have

\footnotetext{
38 Saini Mauga Milo, interview by Louise Mataia-Milo, 4 December 2014, Ta'u, Manu'a.

${ }^{39}$ Milo, interview.
} 
the final say over her life. Nor did her mother, her only living parent at the time. The church minister sealed her destiny when he decided she should marry and stay at home. Here lies the tension between the powers of the institution and the agency of individual women. The church controlled women's access to education. The church permitted some education for girls but decided what the limits should be. Saini's case shows how the clergy could abuse their religious position to make important decisions for young women. The zealous belief that the church minister's actions and decisions were informed by the 'musumusuga a le Agaga Paia - whispers of the Holy Spirit' conditioned many Samoan families to accept and respect the faifeau's decisions as the final word. Saini was never asked if she would like to consider her options nor request advice from her mother who was her only living parent.

The way in which Saini and Faapusa were directed by the clergy to accept their new lives contrasts with the lives of other young women and girls. Sister Consolata's memoirs relate the story of Mauga, adopted by a marine named Charles Burns who was billeted with a Samoan family. Consolata writes:

Samoan children are taught to work at an early age, and Mauga's task was to do the cooking in the outside oven. Everyday Charles would see Mauga busy at her chores. She was a happy child and often sang while working. He was attracted by her winning smile. One evening he approached her father and asked if he might adopt her, stating that after the war he would like to take her to the States, where his mother would be delighted. The next day there was a council meeting in which the whole family participated. Mauga was asked if she would like to become the Marine's adopted daughter. She consented readily and her parents were honored to have a Marine adopt their child, especially by one whom they were already calling their Charlie. ${ }^{40}$

Mauga's decision changed her life. Charlie negotiated with Sister Consolata to accept Mauga who was a non-Catholic at St Joseph's school at Leauva'a where she was eventually baptised and given the name Laura. Charlie died at Guadacanal, however, and Mauga was never legally adopted. Under the guidance of Sr. Consolata, she completed her education with the nuns and became a substitute teacher with the lower classes. She never went back to her family. She stayed with the nuns and later became the wife of a catechist. ${ }^{41}$

${ }^{40}$ Consolata, Samoa with Love, 45.

${ }^{41}$ Consolata, Samoa with Love, 52. 
The three experiences I have drawn on show the different ways in which young women's lives were influenced by church and family in wartime Samoa. Saini's and Faapusa's experiences differed from those of Mauga who had the choice to make her decision whether or not she wished to be a Marine's adopted daughter. Saini and Faapusa were not given the same freedom by the clergy.

The elevated position of church minister meant that the minister's wife was also in a position of power. Her influence was in the area of teaching domestic skills to the young women and reading and writing to young children at Sunday school. At church, the minister's wife headed the church's women's groups which consisted of all the mothers and elder women of the church. The women's group's primary role is prayer and fellowship and secondly to assist church development through fundraising or by organising activities to further improve the spiritual or physical outlook of the church. Women's communal roles as co-ordinators and directors of village activities were transferred into the church context where the minister's wife, an outsider in the traditional sense, acquired more authority over the village women in the fellowship. At gatherings, she occupies the space usually reserved for the leader of the aualuma, the taupou. The minister's wife though has no power over the aualuma when they come together as a village group although the group acknowledges her position as the pastor's wife.

\section{Amanda's life in the church}

Some young lives were influenced by their families' religious conviction to replace family members lost to Protestantism. This was how Amanda came to be in the SMSM convent at Leone. It was common for a nun to take guardianship of a young girl for religious reasons. Amanda's mother's family in Safotu, who were devout Catholics, appealed to Sister Mathew before she left Safotu to serve at Leone, American Samoa, to adopt one of Amanda's mother's children to be raised in the church as a replacement for the mother who had married a non-Catholic. In those times, Catholics were expected to marry within the church. Sister Mathew accepted, and Amanda was sent to stay at the convent when she was only ten years old.

This commitment to educating young girls is reflected by Bishop Darnand's statement that 'the Christian families are honored to give their children to the service of the 
Church. ${ }^{, 42}$ This comment reflected an obligation for parishioners to serve the church as a manifestation of their faith. Samoan women were at the mercy of the clerics to be molded as they saw fit. They might have thought it was a good thing for the women but from Saini's and Faapusa's view it was not the life they wanted for themselves; they were duty bound. As Saini tersely commented, 'e sili a le usita'i - best to obey. ${ }^{143}$

Sister Mathew raised Amanda according to the Catholic ideal of living a pious and virtuous life and aspiring to be a nun. The nuns ran the St. Theresa's School for girls, which the Naval administration later renamed Leone Girls School. Amanda attended the same school and completed Grade Nine there in May 1941. 'I finished my education in May 1941, and taught in the $5^{\text {th }}$ grade, in the same year until 1942 when the bulk of the forces arrived. Sister Mathew, who taught at the school, was taken away with all the nuns, and I returned to my family. ${ }^{44}$ Amanda's life was interrupted by the arrival of the war, which led to the removal of the clergy from American Samoa and the schools being closed down. ${ }^{45}$ All of the SMSM sisters were on Upolu for the duration of the war. $^{46}$

The churches' intimate involvement in women's lives normalised a very narrow platform of life experiences. Life was predictable, especially for women in the villages, while many personal aspirations were never reached. The notion that education is a path to making informed decisions and individual independence had not yet entered the churches' thinking in Samoa. Sister Makerita's reflections on her own life experiences as a young woman, when she was left at the school at Moamoa against her will to become a nun, encapsulate many women's experiences before and during the war: 'E fai tele lou olaga - My life is governed by many. ${ }^{47}$ Women and girls had little autonomy or control over their lives.

\section{Sister Makerita}

An analysis of Samoan women's wartime experiences with the church reveals individuals' personal wishes for what they wanted to happen yet the situations they were

\footnotetext{
42 Bishop Darnand to Fr. Fotheringham, 14 August 1939, OMPA reel 63, ATL

${ }^{43}$ Interview, interview.

${ }^{44}$ Iuli, interview.

45 Iuli, interview.

${ }^{46}$ NZ Administration list of the SMSM sisters in Western Samoa, 1941, IA1 3046 171/2/1, ATL.

${ }^{47}$ Leauna'i, interview.
} 
in did not always allow them to be fulfilled. The interviewees were too young during the war to have the courage to reject any influences in their lives. Instead, they played along with the status quo. Scott refers to an element of human experience as the repressive social instruments and processes that individuals struggle against. ${ }^{48}$ In the struggle to understand their position in the greater scheme of things women acquired new experiences and created new identities for themselves. Youngsters observe and obey the adults in the family, so their ability to effect change is often unrealised at a younger age. This does not mean they are powerless to exercise their agency but they were bound by the reciprocal nature of the relationship. In 1941 Makerita, from the village of Manono, found herself is a similar situation.

Makerita decided to follow her paternal aunties everywhere they went, to learn from them. Makerita was very close to these women and was intrigued by their influence in the aualuma and around the village. She remembers going with them to the aualuma, and enjoyed her childhood experience in this circle as one of the 'runners' sent around the village by the older women to collect something or to assist other young women to serve the older women of the aualuma. One can say that Makerita grew up at the aualuma where her aunties and other women taughter her how to communicate with her peers and learned the manners of behavior around chiefs, and older women. 'Of course before you are sent out to the family to ask for something they instruct you on what to do when you arrive at the home you were told to go. First, when you get to the family, you go to the back and sit, the first word that you say is, 'talofa and faamolemole - greetings and please' before you give them the message. That was my education at the village. ${ }^{49}$ However, a serendipitous meeting with her maternal uncle changed Makerita's life path, bringing her closer to the church.

The NZRE often hired casual labourers for plantation work. Village groups often exploited this opportunity to raise funds. While the war was on, the aualuma from Salua went to work at the Tuanaimato plantation and Makerita went along because her aunties were part of the group.

My uncle, my mother's eldest brother was the overseer there [at the Tuanaimato Plantation]. Some of my cousins saw me when I got down

48 Joan W. Scott, "The Evidence of Experience," Critical Inquiry 17, no. 4 (Summer, 1991), 779.

${ }^{49}$ Leauna'i, interview. 
from the truck with the workers when we arrived. They told their father and I was sent for. He asked what I was doing there. I told him that I was there for a tafao [aimless wandering/ hanging out/roaming]. He replied, 'E te tafao o oe o se moa - You roam as if you are a chook? You are not to go with the workers. You will stay here.' And so I did. I think my uncle was embarrassed that I was one of workers. My uncle wanted to take me to school but I always wanted to go with my father's sisters. Schooling in my younger days was at the catechist's house. ${ }^{50}$

Makerita obeyed her uncle's instructions and stayed with his family at the plantation.

She never saw the crew she came with again. Makerita was oblivious to how her life was going to be subtly choreographed by her uncle.

The nuns at Moamoa had an arrangement with my uncle that they supply tobacco to sell to the plantation workers. On Sundays my cousins would hike up to Moamoa to take the nun's money and to visit my aunty who lived and helped out at school. I went with Sivao and Kiose. That was also the Sunday that one of the village girls, Kalala Siafausa from Lepea will receive her Marian medal at mass and we wanted to see that. Little did I know that my uncle had planned it as a way to take me up to Moamoa. After we left for the house, my uncle telephoned my aunty and the nun in charge informing them that I was on the way and to keep me there. At the end of the mass I looked for my cousins. I found out later that they left before the end of the mass. One of the girls from Manono that I knew said for me to follow the students' line back up to the school, so I did. That is how I ended up in the church school. The nun, Sister Malia Paula, tried to sooth me and said to stay with her but I did not know her. I was not familiar with this sort of life. My aunty then came and ask why I kept on crying, I should be alright because she was there. I told her I did not come to stay I had to go. But I could not.... Over time I decided to become a nun. $^{51}$

The conflict Makerita experienced occurred during the war at a time when neither Makerita nor the church had much control over their situation. In most respects this experience was incidental to the war, but the war perhaps shifted her attention away from her own anxieties about the life she lived and yet had no say in. Being young and bound to obey her elders, Makerita conformed to her uncle's plan, which she ultimately saw as her own choice. This was a cultural repressive mechanism at play.

Makerita's story reminds us that not all wartime experiences were directly related to the war. People continued to live their lives and were affected by other factors that led

\footnotetext{
${ }^{50}$ Leauna'i, interview.

${ }^{51}$ Leauna'i, interview.
} 
them to other positions and identities. Makerita was one of the aualuma workers from Manono. She was also a niece of an uncle who wanted an education for her and placed her in the church and on the pathway to the turning point in her life when she decided to become a nun. This subtle plan meant young women like Makerita and perhaps Faapusa were unconsciously active subjective participants in the transformations in their lives. Makerita had to forgo her independence as an individual and conformed to a devised 'choice'.

\section{Alice and Faafouina}

While individuals may have appeared to conform to social expectations, there was always a tension between the repressed individual's will and the conformed self to 'keep the peace.' Alice's view of what she wanted to do reflected this conflict between the individual's interests and society's expectations.

When I go home, those same girls that go with the Americans, I can hear the older women say to their girls, 'why don't you be like Alice?' And I used to say [to myself], No! This is not Alice; I'd like to do what they were doing. Because I'm so protected. Because there's a limit to things that you could do and then when you go out and you see those girls and when you see people they say, 'you are a very good girl' and so whatever, all the nice things they used to say about you. You used to think, 'yeeaah! In here (outside of the convent) yes, but in there (the convent) I want to do what you're doing too.' But I can't, I am not allowed. Even I say that to myself, I'll just show this face to people that I'm a very good person but inside, I wanted to do what they were doing but I can't I'm not allowed. ${ }^{52}$

Putting up appearances became a personal strategy to alleviate the anxieties and the pressure being put on individuals to meet societal expectations. Seeing young women of almost her age socialise with the marines was more exciting than the plain life she lived in the convent. But Alice's life was already planned for her. She was going to become a nun. At 15 years old in 1942 Alice moved from the Savalalo convent to another convent in American Samoa for three years. An uncle's wife, who was a devout Catholic as well, talked Alice out of becoming a nun and she eventually left convent life. Alice's experience perhaps echoes a reality familiar to other young women who may have repressed their personal desires while seeking the courage to change.

52 McElhiney, interview. 
Alice's wartime experience contrasts with Faafouina Selesele's experience in the village of Satupa'itea, in Savai'i. The oral histories recounted by these women suggest how young women were always under pressure to meet not only the churches' expectations but their parents' expectations as well. They also add to our understanding of how women endured such pressure. Faafouina's example indicates how some young women tried to shake off these influences by making decisions for themselves and that some had the hardy personality required to weather the consequences.

I ran away with my husband and lived with his family [in Palauli] ... while I was still attending the pastor's school at our village. It was only after a while that I said to my husband that we have to return to my family and apologise to my parents for what we did that we got married then. But my parents were very disappointed because I eloped with the man, and that ruined their reputation in the village. My father at the time was very active in the village [and national] politics at the time so this did not look good on him. ${ }^{53}$

Faafouina made a conscious decision to remove herself from such role-model duties when she decided to elope. Looking back, she laughed off her gutsy youth: 'The devil got the better of me when I took a husband and left school. Ha ha. But o le mea na ou malie $\mathrm{i}$ ai - it is what I agreed to. It was totally the opposite of what the faifeau was preaching every Sunday. Ha ha. ${ }^{54}$

Faafouina's case illustrates that some wartime experiences were about people trying to cope with their own personal circumstances and trying to make choices for themselves. Although Faafouina's decision may have been frowned upon by the village and her family, the main thing for Faafouina was that she made her own decision of her own accord: 'O le mea na fai io ma loto! It was my decision. Mine and my husband's.' Faafouina risked being disowned by her parents and it was never an option for her to seek refuge with the church. Faafouina never regretted her choice. Her attitude towards the church is very telling of how some individuals viewed the church that they grew up in during the war.

The minister always preach to the people to be good. But we come home from church and do exactly the opposite. Some of us in our generation did not really care. He preached to us, warning that there will be people coming

${ }^{53}$ Faafouina Selesele, interview by Louise Mataia-Milo, 18 October 2014, Selesele, Vaega, Satupaitea. 54 Selesele, interview. 
for the war but we did not really bother. Each of us had our own individual plans, and we did not even take the arrival of that 'malaga' seriously. ${ }^{55}$

The experiences of Makerita, Alice, and Faafouina, echo only some of the different ways in which the church, the war, and their agency intersected. At times the pressure placed on them as individuals could be repressive, and was complicated by the close connection to the families which they had to obey. What is interesting also is that these three lives during the war period although different are also similar in some ways. The wartime church was a repressive mechanism which caused Faafouina to rebel, Makerita to conform and Alice to rethink her calling. These stories also improve our understanding of the influences that could come to bear on personal choices.

Reactivating women's wartime memories about their relationships with the churches reawakened concealed concerns about the uneven nature of the relationship. While all the research participants responded that the church was good for spiritual nurture during the war, they almost all said that the church did not help them cope with the changes during the war and they ended with a critical view of the church. Alice's opinion is that the church did not do anything to prepare young women for the arrival of the war. 'I don t think so ... I do not think we really know what was going on. In fact, I do not believe that we were greatly affected very much. Maybe the people outside. ${ }^{56}$ Alice's reaction suggest that the convent offered protection from the social life on the other side of its walls. Her opinion about the church though is similar to those of other women who experienced the war in the rural villages.

Tiresa of Vatia claims that the church was the one that needed help more than the villagers. Her experiences living in a very remote village provide a picture which contrasts with those from Apia, Pago Pago, and Nu'u'uli. Tiresa remembered that during the war, it was the church that required assistance rather than giving assistance to the women. Tiresa was adamant that the church did nothing for young women at the time.

The church [LMS at Vatia] did not help the women. They had nothing! What did they have to give to help us? If the donations [alofa] to support the church minister did not reach a hundred dollars, what is there to expect?

\footnotetext{
55 Selesele, interview.

56 Alice's opinion contrasts Makerita's wartime experiences at Moamoa where they were told to 'listen carefully and following the instructions'.
} 
We saw that it was only during the war that the alofa reached a hundred, when most of the time, the alofa would be only $\$ 20$. And that came from selling fish to the marines or from women selling the mats. ${ }^{57}$

Tiresa and Alice may have found it difficult to express these opinions when they were younger. Challenging the authority of the church, was unheard of in the 1940s. All three women claimed that they reserved a sense of indifference to the church, but they did not have the courage to show it.

This study has not found evidence of any specific programs set up by any of the denominations to cater for the welfare of women during the war apart from the usual church services on Sundays. In a way, this study presented an opportunity that allowed them to make sense of both the wartime past and their current realities. Perhaps the most critical view of the church during the war comes from Tuala who argued that the war did not change the way the church thought about women.

Women's place in the church (shake her head to signal there was no place for women in the church). O le taimi lenei ua ese - this time it is different. Butt before the war, there was no role. They always put down the women. [Tapping the table.] They did not try to improve women's position. Although women were members of the choir, they all listen to the word of the minister who was treated like a God. Aua, e fetu'u oe! E fetu'u! Because you will be cursed (by the faifeau). I think the church will have to realise that the time has changed. And the time has changed people. The church will have to realise that. NO! The women at this point are still the same. Specifically, women and the church. ${ }^{58}$

Tuala is not alone in her opinion the women's place and role in the church, especially during the war years. She holds the view that the war did not help improve Samoan women's place in the church. Tuala's responses reflect the different approaches of the various Christian denominations. Tuala who grew up in the LMS church, being the grand-daughter of a church minister, lived a privileged life as a part-European young woman and at the same time valued her Samoan culture. Weary of the of war, Tuala and some of the women she lived with believed of only one thing that would help them cope with the changing social context was for the war to end.

We wanted the war to finish. That's the main thing. The women will get on with their lives. The girls will get on with growing up. But it should be

${ }^{57}$ Fiti-Brown, interview.

${ }_{58}$ Hunter-Malietoa, interview. 
finished. Come to the end. What's the use of killing people and not having graves for it? The women should improve on their work but they were not improved, something stopping them - the church. ${ }^{59}$

Tuala sums up the feelings of many Samoans. The war was something that neither they nor the churches could control. Both were struggling to negotiate the wartime circumstances.

The analysis of Samoan women's wartime experiences with the church shows that there were many sides to the relationship. The churches' authority diminished, but they still had a repressive influence on women. The churches dominated and altered the trajectory of women's lives yet during the tumultuous event that affected young women's lives, the churches did very little to offer guidance or spiritual advice that was more meaningful to them. Some of the women ended up in the church during the war, as was the case of Sr. Makerita. On the other hand, there were changes afoot, especially in education for some denominations that allowed women to discover potential post war careers. Women were also actively employing their traditional roles as organisers of fundraisers and helpers to the churches they serve and as companions to the soldiers who needed help. Women gave themselves to the service of the church, during the war, yet, as Tuala and others note, the war did very little for the women's place in the churches and called for a change in attitude towards women. All the interviews show that apart from the schools, which include village/mission schools at the minister's residences, there was very minimal exchange between the churches and the young women in the churches' traditional role of spiritual nurturer.

${ }^{59}$ Hunter-Malietoa, interview. 


\section{Chapter Five. Consuming Wartime Pleasures: Samoan Women's Engagement with Wartime Popular Culture}

In this chapter, popular culture is used as a frame to bring into focus some of the everyday aspects of women's wartime experiences. These are experiences that have escaped the notice of those scholars who share the view that wartime economics, mostly Samoan men's economic activities, stimulated a series of social transformations which led to economic benefit and outward migration. ${ }^{1}$ By contrast, the focus on popular culture provides a new way to explore how women effected 'on the ground changes' during the war. Social change is a messy internalised personal process that does not always have a neat linear (top-down) trajectory with clearly defined boundaries. The women's narratives reveal that social change is the sum of agency. Women's engagement with wartime popular culture is a significant example of how new experiences create new knowledge that can be adapted and integrated to local situations, informing cultural practices that are relevant and useful to families.

Popular culture is the way of life, interests and things that appeal to ordinary people in their everyday life rather than the educated few. Wartime popular culture in this research includes the cultural materials or objects specifically designed by various army departments to regulate morale and to drive the patriotic will to defend one's country. This view is in line with the Gramscian approach to popular culture that John Storey describes as a 'compromised equilibrium.' In other words, wartime material were tools designed to sustain control of the soldiers' psyche and to oppose any opposition to a cause. However, the theatre of war was not an isolated environment. Like all other places of the war, whether in combat zones or peripheral areas such as Samoa, ordinary people encountered wartime popular culture. A wide variety of media such as films, music, cartoons, and adventure stories were commissioned and were shipped to the men and women deployed to the different theatres of war around the world. ${ }^{3}$ This was how wartime popular culture catapulted into predominantly indigenous societies such as

\footnotetext{
${ }^{1}$ Franco, "Samoans, World War II, and Military Work,".

2 John Storey, An Introduction to Cultural Theory and Popular Culture (Athens: University of Georgia Press, 1998), 12-14.

${ }^{3}$ James Cooke, Chewing Gum, Candy Bars and Beer: The Army PX in World War II, (Columbia: University of Missouri Press, 2010).
} 
Samoa that was occupied by the Allied forces. Women's engagement with this culture would influence people's lives in significant ways.

\section{Popular culture before the war}

Samoan popular culture before the war was predominantly indigenous in origin though shaped by the churches and colonisation. In the 1920s and 1930s the Samoan women who later experienced World War II engaged with popular culture in a variety of ways. Families and villages provided the main avenues for popular cultural experiences such as Samoan games, singing, making Samoan music and dancing. Daily commitments to family, the community, and the church such as taking part in weaving, the entertainment of travelling parties and religious celebrations were the norm and traditional popular culture functioned as part of socialisation. Chanting, singing, dancing and art were forms of record keeping and taught youngsters etiquette, language etymology, entertainment skills and social control. Songs and dances commemorate important events in people's lives. Proverbial expressions derive from the environment and daily activities such as fishing and hunting.

Popular traditional games in the 1930s included group games such as lape, togitogia nonu, talagatau'i and tolotolouga, just to name a few. ${ }^{4}$ Ana Peletisala of Solosolo confirms that these were the type of leisure activities that many Samoans were into either in the moonlight or during the day.

Sa matou faia [taaloga] e pei o le toliga nonu, o le talagataui. E sau le isi tagata nofo i o ta luga ia sau le isi si'i mai si'i mai. - We used to [play] the games such as the toliga nonu and the talaga taui. This is where one other person comes and sits on your lap, and others will do the same on top of the person sitting on you. ${ }^{5}$

Faanunumi recalled that some of the favourite pastimes for young women in her village and district were games such lape, and a game called poge, which is similar to hide and seek: 'e nonoa mata i le i'e ae o isi e lalafi. Ae ota tei ota tago atu o le tama ota alu le atoa - your eyes are covered while others go to hide. [Then she had to go and find where

\footnotetext{
${ }^{4}$ Lape is a ball game similar to softball while, as described by Ana, togitogia nonu involves people sitting on top of one another to form a pillar. Tolotolo Uga' (crawling crab) is a guessing game where one team tries to guess the identity of a participant who is concealed behind a mat (who may emit short squeaks to help or confuse identification) while the other team sing a short song.

${ }^{5}$ Savea, interview.
} 
they hid.] I get frightened when I touch a boy, I run!' According to Faanunumi, the best part of the experience was the entertainment and feasting at the end. It was the custom for the losing team to provide food for the winning side as a forfeit. The thrill came from foraging food to give to the winning team. Faanunumi and her sister would often get their brother into trouble because of this.

I would persuade my brother Sou, to climb my father's coconuts that grew by the shore. Father did not like people climbing these coconut trees. So my sister and I forced our brother to climb the coconut in the dark, and he has to climb down with the coconuts. He would then hand them to my sister, Vaileta who would then pass them to me. Everything has to be done in the dark and in quiet in case we get caught and then get a hiding. ${ }^{7}$

Samoan women also engaged with indigenous popular culture in gendered groups such as the aualuma. As a younger sister of a chosen taupou, Faasalafa remembered her prewar experience with Samoan popular culture as part of the aualuma.

O aso ia, sa momoe tasi uma teine i le fale o le aualuma. In those days all the young women slept together at the house of the aualuma. In the evening, if an aumoega comes we would sing and play the guitar and don't sleep - it was always the Solosolo village anthem that we used to sing and dance to - o le vi'i lava o Solosolo sa usu e sisiva ai. ${ }^{8}$

Singing in this instance was associated with learning the etiquette of acceptable behaviour during the aumoega. At the same time, singing the village anthem was a public declaration of one's knowledge of genealogy and history.

Samoan women's engagement with popular culture reflected social and racial divisions. Colonial social capital gained by the accident of birth and family wealth enabled some half-caste women to have a more extensive experience with foreign popular culture compared to women in the villages. ${ }^{9}$

Samoans with western connections sometimes had their daughters educated in Germany, the United States or New Zealand, exposing them to a much wider range of pre-war popular culture. The young women returned to Samoa and brought with them

\footnotetext{
6 Tupai-Taeao, interview.

7 Tupai-Taeao, interview.

${ }^{8}$ F. Leota, interview.

${ }_{9}$ Damon Salesa, "Emma and Phebe: 'Weavers of the Border'," 145-67; Alailima, Aggie Grey: A Samoan Saga.
} 
some of the culture they had experienced overseas. It is also important to note that there were half-caste Samoans who chose to live as Samoans and who did not use their European connections. Amanda Galea'i is of German and American heritage. Despite her apparent European features, Amanda maintained that her family's lifestyle was grounded in the Samoan way, though they were aware of their foreign heritage. ${ }^{10}$

Singing and entertaining were also part of school life. Figure 8 below shows young Samoan women dressed in the fashion of the 1930s performing Christian plays and Samoan dances. Ana claimed that students routinely performed such plays and dances to celebrate church occasions such as the Bishop's birthday, feast days and jubilees or centenaries. ${ }^{11}$

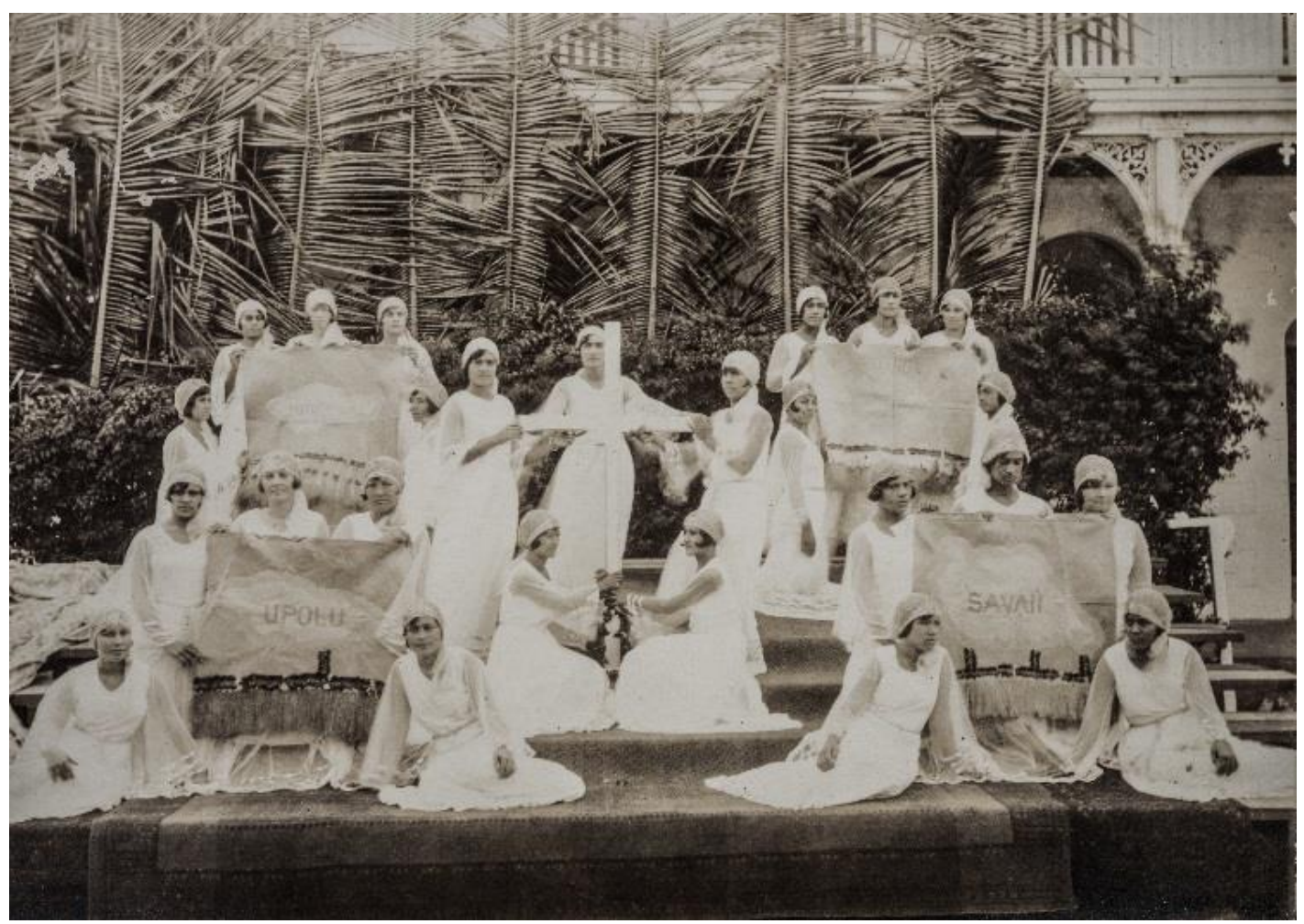

Figure 8 Drama: Students of a Catholic School in the 1930s or early 1940s. The performance is probably about the central place of Christianity in Samoa, represented by the crucifix in the middle, surrounded by maps drawn on Samoan fine mats of the four main islands of the archipelago-Upolu, Savai'i Tutuila, and Manu'a. (Source: Archdiocese of Samoa Archives, Vailima.)

\footnotetext{
${ }^{10}$ Iuli, interview.
}

${ }^{11}$ Savea, interview. 
The LMS and the Roman Catholic churches had centenary celebrations in 1930 and 1945 respectively. The Malua Theological College also had its centenary in $1944 .{ }^{12}$ Songs and dances were composed to commemorate these milestone events. Ana recalled her role as a student during the celebrations associated with the 1945 centennial of the arrival of the Catholic Church in Samoa.

We had the centenary celebrations at Moamoa, the headquarters of the Catholic Church. All the Catholic schools attended and our school hosted all of them. The two schools from American Samoa, at Leone and Lepua, they came and performed. Even the schools in Savai'i. To prepare for the guests all the students at our school had to make coconut cups and clean them by scraping off the husk from the shell - sa valuvalu ia ipu popo e faaaoga e tali ai le toatele e inu ai latou ti - we cleaned the coconut cups so they would have a cup to drink their tea from. ${ }^{13}$

Athough the task may seem insignificant, it highlights the means and resources used by the Samoans in the 1940s when hosting large events and traveling parties. They are very different from contemporary Samoan society. The festivities, according to Ana, went on for a few days. Her memory focused on her role as a student, enjoying the spectacles of the event, which were usually the things that appealed to young people such as the drama performance and dancing to the music played by the Vanila Boys' School.

They built a huge stage behind the cathedral at Moamoa and our school and the Vanila boys' school brass band sat on the stage facing the audience. We were all excited sitting next to the faili, the brass band. Fr. Petelo wrote a play that other students performed in front of us on the stage. It was really nice and everyone enjoyed it. The very next morning, the Vanila brass band led the pilgrim march from Moamoa all the way to Leauva'a and and then back again. All of the schools did it and the band was the best thing about it. $^{14}$

\footnotetext{
12 Malua Theological College, "Malua Theological College History," http://www.malua.edu.ws/History/tabid/4285/Default.aspx, accessed 20 November 2016.

13 Savea, interview.

14 Savea, interview.
} 


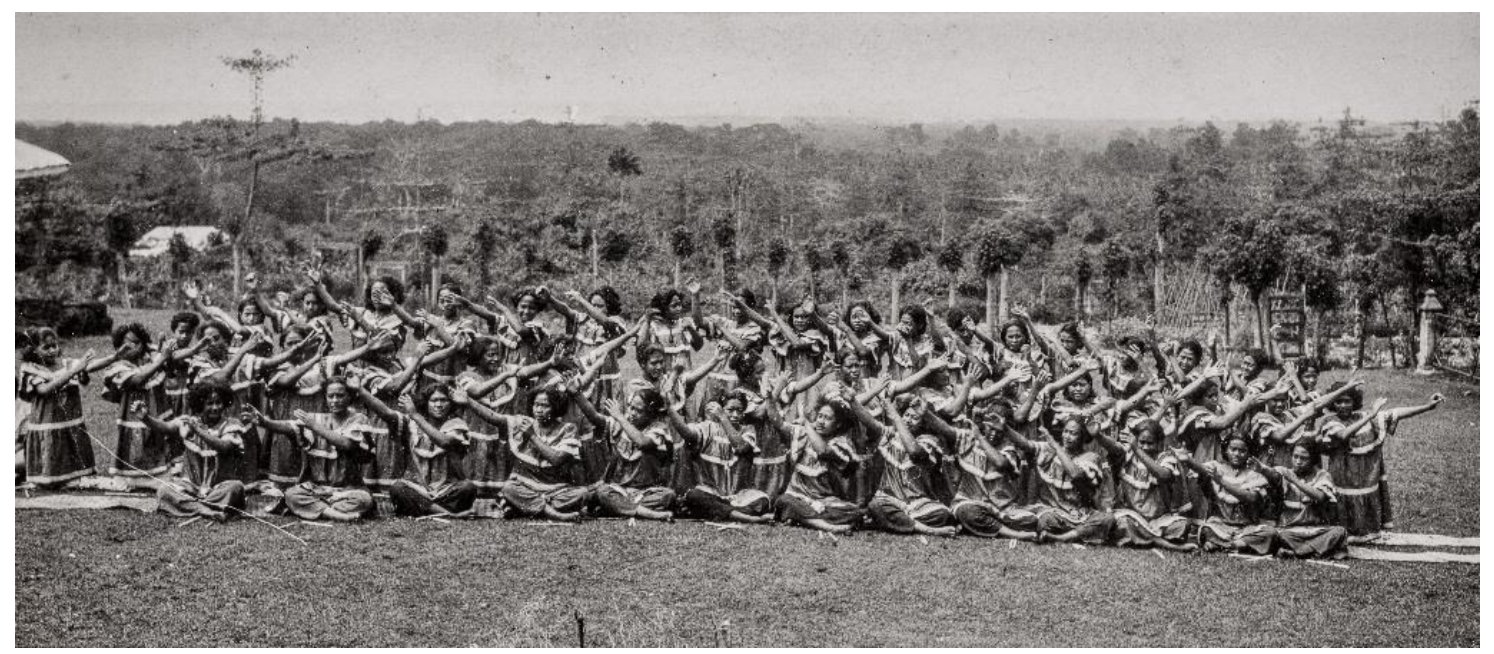

Figure 9 Students of the SMSM Convent School, Moamoa, in the late 1930s performing a maulu'ulu dance in the school's 'apana' uniforms, at one of the church's celebrations. (Source: Archdiocese of Samoa Archives, Vailima.)

Ana clearly recalls young people's love of festivities. Singing and dancing had great appeal to youth in Samoa. At such times school rules were relaxed and, in the celebratory spirit, the school would decorate the buildings and adorn the dancers with flowers and colourful uniforms. However, these celebrations were infrequent and once the guests left the strict rules of the hostel life returned.

Fashion is also a part of popular culture. Ana related that the nuns did not approve of bodily adornment. The nuns' preference for certain kinds of dresses stimulated an evolution of the school uniforms and the widely-accepted fashion in the early 1940s.

The nuns do not like seeing you wear any jewellery. Either earrings or rings. They just walk up and remove them. They tell us we are not allowed to wear them. They explained that we were not allowed because only married women wear earrings and wear rings. That was the nun's explanation. We did not really like it. It was Sr. Alefosio (Alphonse) even the way girls dressed in the apana uniform she did not like it one bit - e ita ia o le taupousa i le apana. She preferred le 'ofu molesi', I am wearing an ofu molesi, to the apana. Because the ofu molesi is much lighter and the apana is a nuisance, especially when we do physical work like loading the horse drawn cart with the kapisi for the market. ${ }^{15}$

The modesty in dress and deportment taught at the mission schools reflected Christian virtues of purity and chastity. The ideal was to avoid encouraging sexual attraction in others, so the whole body was covered in the 'apana' or Mother Hubbard dress, as in

15 Savea, interview. 
Figure10. Adornments were mainly the Marian medals. In the LMS schools, girls wore their hair long, in one or two plaits, in a style from the Victorian age. ${ }^{16}$

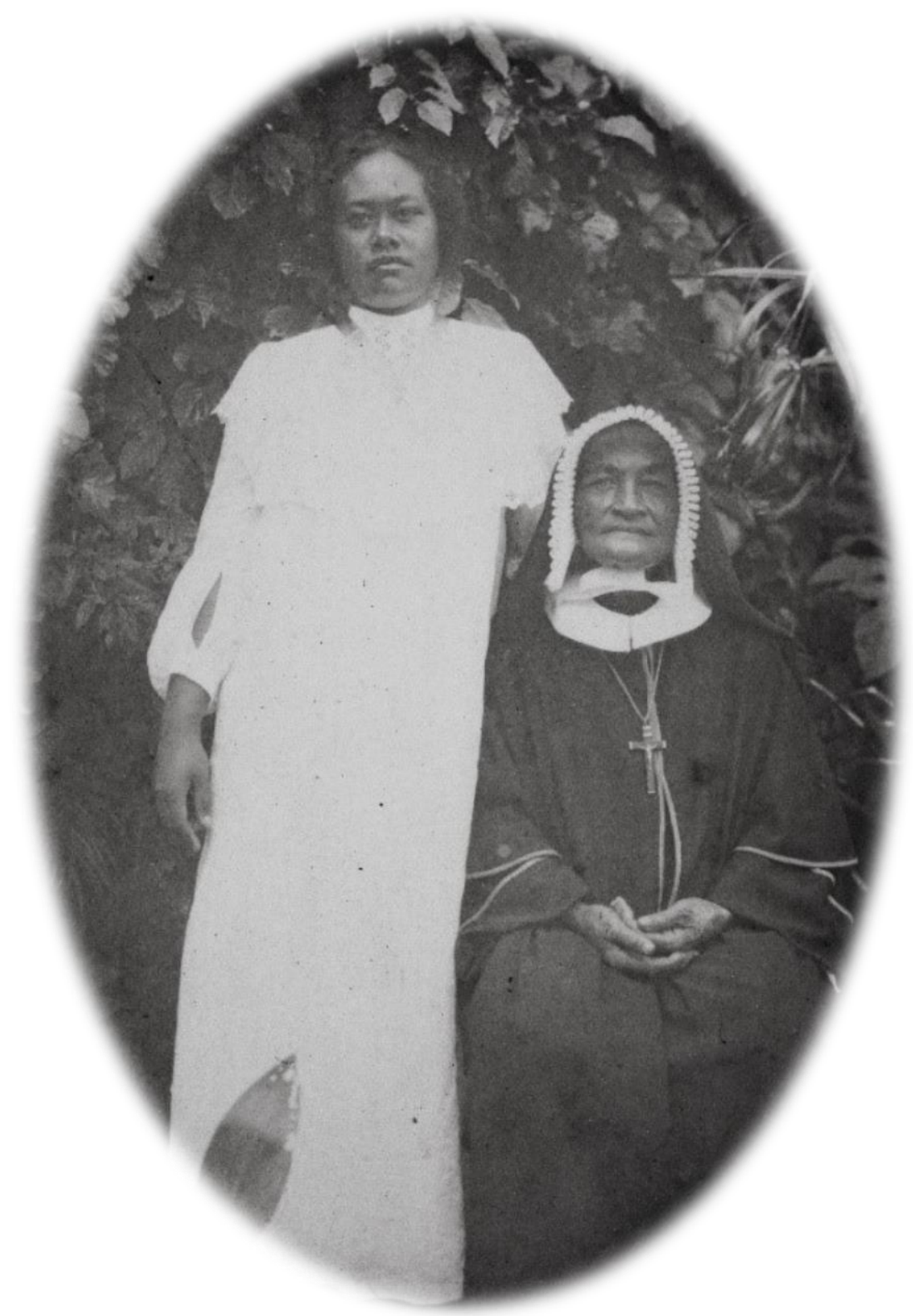

Figure 10 Unidentified Samoan women. The younger woman wears a full apana (Mother Hubbard dress) and a Catholic nun in her traditional habit. (Source: Archdiocese of Samoa Archives, Vailima.)

16 Elizabeth Marchette Roach, "From English Mission to Samoan Congregation", 112. 
According to Ana the 'apana' was not practical compared to the 'ofu molesi' - a transliteration of 'modest dress' - which was a newer, shorter version of the apana that was popular in the 1930s. 'Ae e fiafia lava i ai teine matutua - the older girls liked it'. ${ }^{17}$ The Catholic nuns turned the apana dress into a puletasi, a top in the apana style usually worn with a plain matching lavalava. Figure 11 shows that the puletasi apana was a formal uniform worn by the students at Moamoa on special occasions. The decision to move away from the apana signalled that the church community was changing with the times, at least in terms of 'modest fashion'.

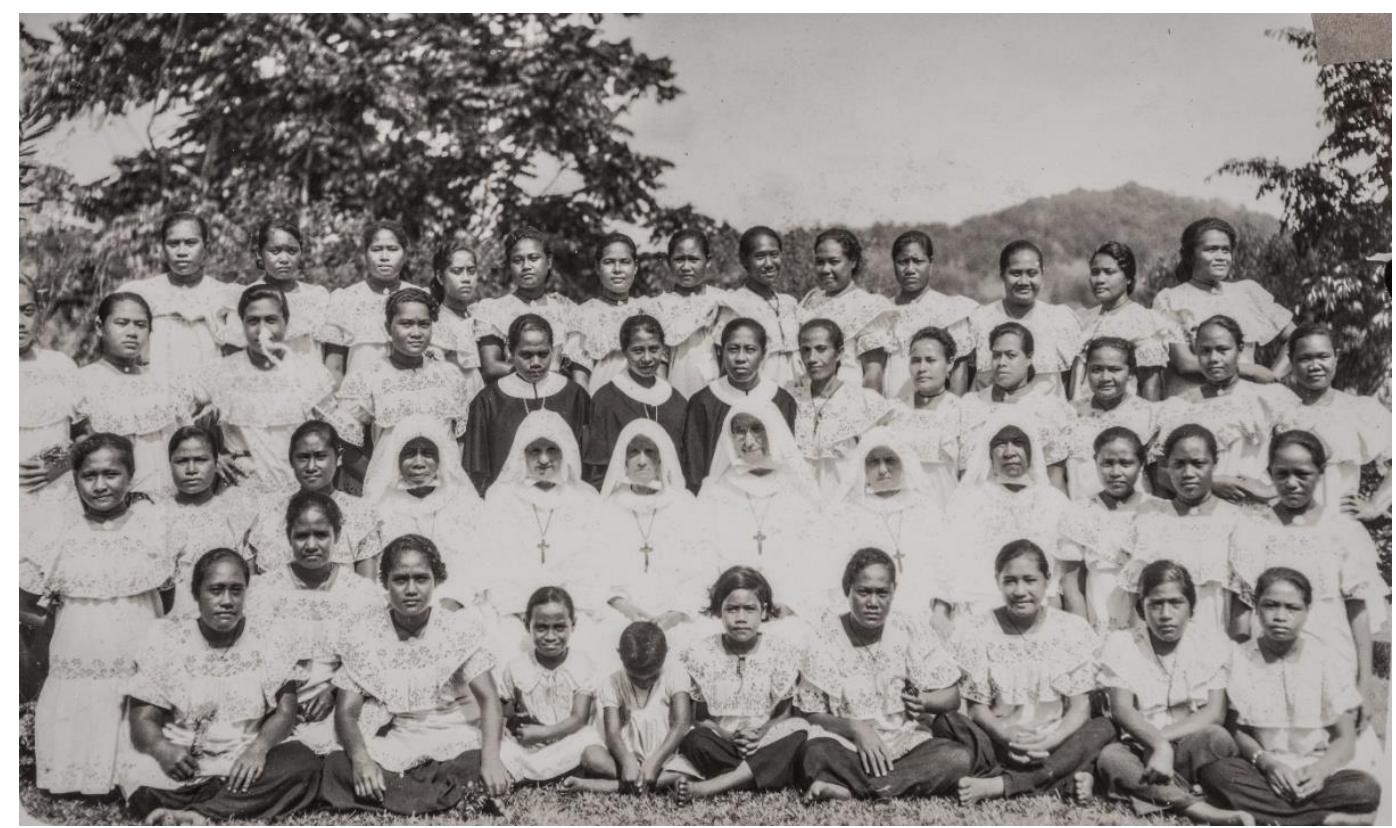

Figure 11 Many young women educated in the Catholic Church became nuns. This photograph was taken in 1939 at Moamoa, after four novices took their perpetual vows. The novices standing in the middle of the third row are L-R -Antonina Apolo, (in dark habits) Sr. M. Sosefina, Sr. Malia Selina and Sr. M. Falanika. Sitting in the middle row are: Sr. Malia Kalala, Sr. M. Hedwige, Mother Mary Alphonse (whom Ana claimed did not like the Apana), Sr. M. Paula, Sr M. Leonie, Sr. Malia Filomena. The students are wearing a modernised version of the apana as a puletasi and are embroidered with flowers, usually in the Marian blue colour. (Source: Archdiocese of Samoa Archives, Vailima.)

${ }^{17}$ Savea, interview. 


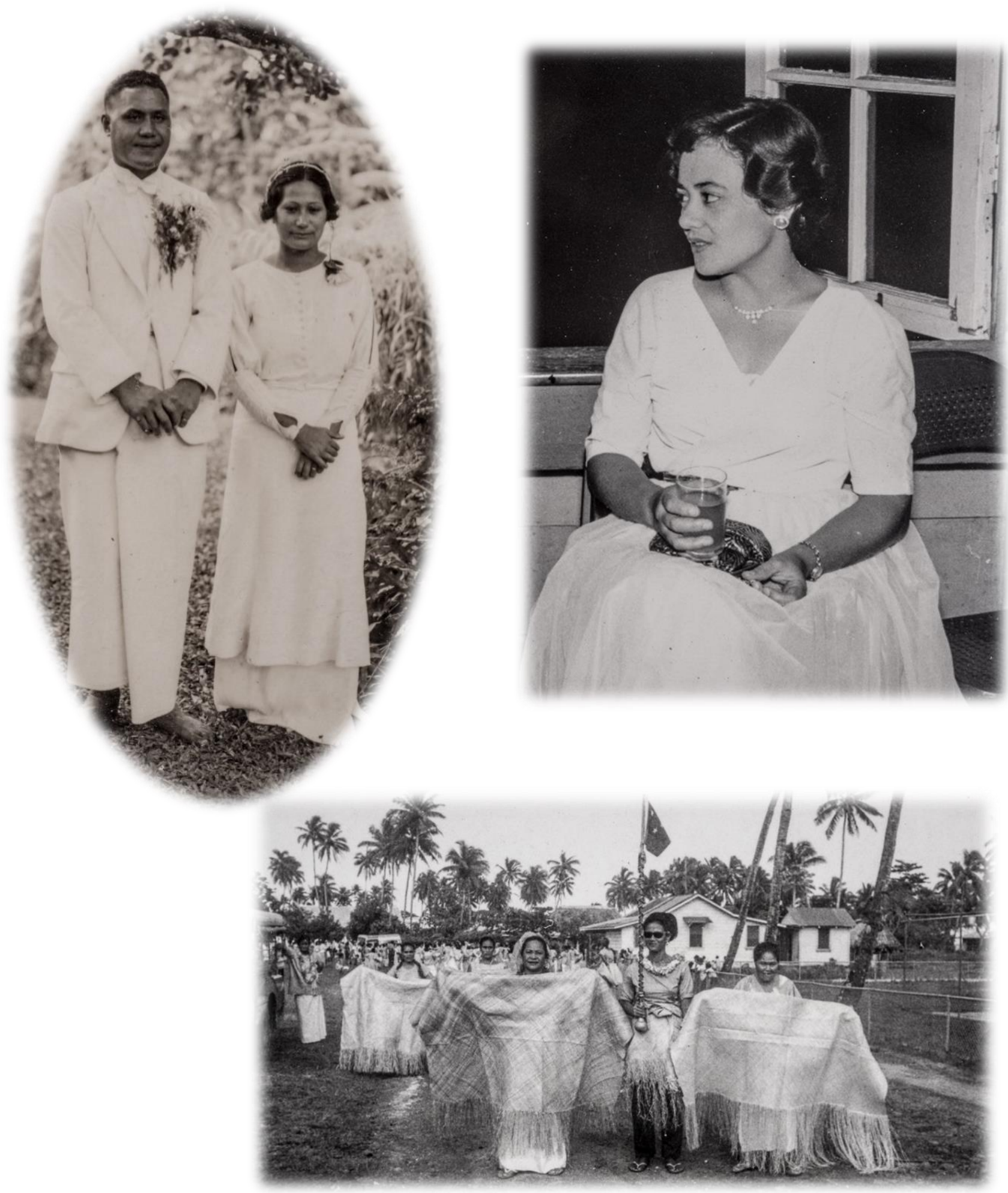

Figure 12. Snippets of Samoan women's style of dress from the 1930s, 50s and 60s: Clockwise from the left: The wedding of Tamasese and Noue in 1924 (notice how the wedding dress is worn with a lavalava, as a puletasi; Moira Walker, 1951; A scene at a Faalelegapepe, women showing off their newly woven fine mats. The woman in pants led the march, circa 1960. (Source: Archdiocese of Samoa Archives, Vailima) 
Geography also shaped pre-war engagement with popular culture. Urban villages such as Apia and Vaiala, Pago Pago and Fagatogo, where the half-caste and foreign population were more numerous, were more open to the social exchange of ideas and cultural objects than the remote villages. There are fewer hotels, bars and stores as one leaves the urban setting and moves toward the villages. In the villages interactions with foreigners were less frequent and were limited to the general merchant supply stores. Villages such as Satupa'itea and Falealili, whose main form of transportation was the fautasi - the long boats - seldom interacted with foreigners. People shied away at the mention or sight of the palagi or visiting foreigner; 'sa matou fefefe i papalagi - we were afraid of the papalagi' said Faanunumi. ${ }^{18}$

Pre-war Manu'a seemed dismal to the youth as compared with the war years. Both Saunia and Saini claim that Samoan culture and religious zeal epitomised popular activities at the time. Saini recalls that 'it was always Kilikiti (Samoan Cricket) that we played. Sometimes our [women's] village team would go to Faleasao or Faleasao would come to play at Ta'u. ${ }^{, 19}$ Saini's relationship with her mother reflected pious virtues. 'My mother told me not to tafao vale - wander aimlessly, like what she was seeing with the young men and women. I should stay at home. ${ }^{20}$ Locally owned family businesses such as O.F. Nelson and Co., Carruthers and Sons Ltd., Bartley and Sons Ltd., imported goods from New Zealand, Australia or Europe. These local companies catered for foreigners, the growing part-European population and the general public. Items advertised in the local newspapers such as the Western Samoa Mail from the 1920s to the early 1940s included products such as Vitalis hair tonic for men, Resch's Double Bitter Ale. ${ }^{21}$ Charmosan face power and cream, as seen in Figure 13, was the only product for women advertised frequently.

\footnotetext{
18 Tupai-Taeao, interview.

${ }_{19}$ Milo, interview.

${ }^{20}$ Milo, interview.

21 "DB Ale Advertisement, Western Samoa Mail, Saturday December 311938.
} 


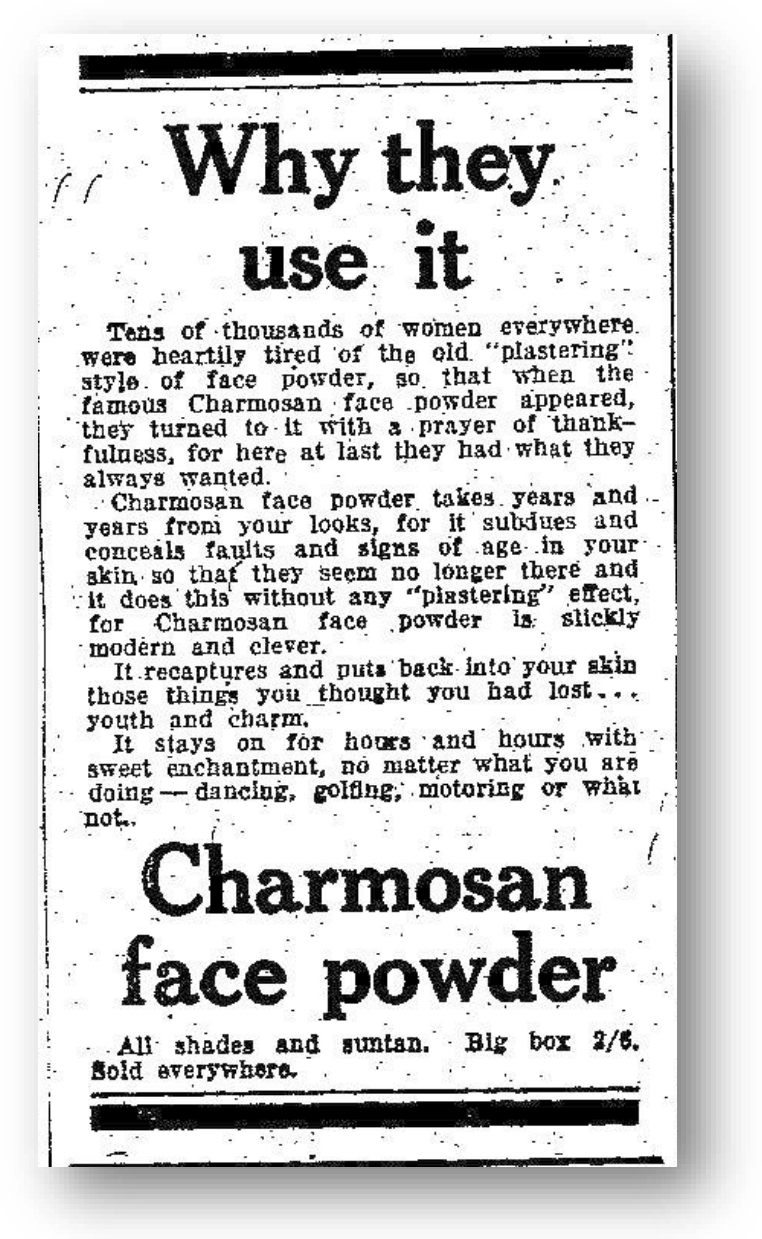

Figure 13. Charmosan Face Powder as advertised in the Western Samoa Mail, Saturday, December 31 1938.

Most of the advertisements were in the English language suggesting that these products were primarily for foreigners and part-European Samoans. The advertisement for Charmosan face power is in English and targets the European part of the local population. The indigenous Samoan notion of a beauty regime, according to Amanda, was just, 'coconut oil and the fisoa, and only when it is available, the Natura soap to wash with. ${ }^{22}$ O.F. Nelson and Co. in the 1938 and 1939 issues of the Western Samoa Mail had advertisements in Samoan on the goods for the 'Faamati' which specifically targeted LMS church members. ${ }^{23}$

\footnotetext{
${ }^{22}$ Iuli, interview.

${ }^{23}$ Faamati is an LMS missionary creation where the congregation attends to the maintenance of the missionary's house, furnishing and fittings. The maintenance is usually done in the month of March (Mati), thus it is called fa'amati (the March way).
} 


\section{Embracing wartime popular culture}

Horowitz's view of popular culture as a feeling of confidence and optimism, 'a genuine expression of creativity that emerged from below', highlights the spirit in which women in Samoa embraced the wartime popular culture. ${ }^{24}$ For most Samoans, the engagement with wartime popular culture was a new experience in their lives. Amanda Galea'i reminisced that: 'We accepted these things [items of popular culture] because it was fun, new and we were all excited. ${ }^{25}$ In Amanda's case, the anticipation of new opportunities and interests removed the initial fear of displacement when the troops first arrived in her village.

The sudden increase of foreign males led to a sudden increase in social relations between the American GIs and Samoan women. Moreover, the newcomers brought with them huge quantities of American consumer products such as food, music and other intangible US cultural items for their consumption. Pre-war popular culture suddenly became less desirable. At another level, new commodities and items of popular culture offered Samoan women a variety of ways to socialise not only with the marines but also amongst themselves.

Caring for soldiers' morale was one of the priorities incorporated into war build-up programmes by the United States War Department. Setting up of the Morale Branch, in cooperation with the Army Exchange Service (AES) and other civilian subsidiaries, was part of a substantial operation devoted to ensuring soldiers' morale was kept high as they transitioned from civilian life to being a soldier. Massive quantities of merchandise, referred to by military officials as 'comfort items', were shipped to American bases, including American Samoa. ${ }^{26}$ These items included shaving cream, soap, cigarettes, magazines, books, food, chewing gum, candy and beer just to name a few. These items were stocked in the Post Exchange (PX) stores and were available for purchase by the servicemen at very low prices. Joseph Cooke's history of the Post Exchange shows how this provision of 'comfort items' ensured the citizen soldier had the primary enjoyments

\footnotetext{
${ }^{24}$ Daniel Horowitz, Consuming Pleasures: Intellectuals and Popular Culture in the Postwar World (Pennsylvania: University of Pennsylvania Press, 2012), 2-3.

${ }^{25}$ Iuli, interview.

${ }^{26}$ Cooke, Chewing Gum, Candy Bars and Beer, 25.
} 
of life.$^{27}$ However, as history has taught, sometimes the best laid plans can go astray. As the marines began to venture out to the villages so did their personal property and the merchandise.

The marines used these 'comfort items' to connect with the local population, projecting a glimpse of American material culture that most Samoans were unaccustomed to. Offerings of candy, cola and books stimulated young Samoans' demand for such goods. The GIs' generosity with these items generated a perception that the GIs were rich, a view that Cooke argues was nowhere near the reality. ${ }^{28}$ The troops' wages were well below those of the average worker in America, but their generosity encouraged Samoan villagers to believe that they had befriended a wealthy and kind ally.

\section{Comfort foods and other new commodities}

The enchanting effect that chocolate bars and chewing gum had on children as well as older Samoans exemplifies the argument that the war was an exciting time of new experiences with food. The military prepared Samoans to be self sufficient during the war by encouraging them to grow their food. Agricultural projects were introduced in schools and in the villages. But a hurricane in 1939 affected food supply. The military brought in flour and sugar to supplement the local diet until the plantations could recover. This move subtly changed a whole generation's taste as they began to aquire a taste for processed food. Amanda talked about the many different things they did with flour during the war:

Ua oge Tutuila, Sau le isi vaatele o le Navy, aumai taga alaisa, taga suka, taga falaoa mata. $\mathrm{Na}$ tufa i nuu uma lava. Ia matou laki ai! $\mathrm{Na}$ fai matou papa falaoa mata. $\mathrm{Na}$ oge, sa fai le matou koko alaisa, alaisa faapopo. Matou aai foi i le sua alaisa. ae sili lava le papa. Aua e na o le falaoa mata lava ma le vai ma le penu.

There was famine in Tutuila. A Navy ship brought bags of rice, sugar, and flour to give to the villages and that was how we got lucky. We made [faa]papa. There was a shortage food here. We had Cocoa rice, Coconut rice, rice pudding and many others but the popular one was the Papa. Because it was just the flour, water and coconut milk. ${ }^{29}$

${ }^{27}$ Cooke, Chewing Gum, Candy Bars and Beer, 11.

${ }^{28}$ Cooke, Chewing Gum, Candy Bars and Beer, 8.

${ }^{29}$ Iuli, interview. 
The war brought new ingredients in huge volumes. Innovative Samoans created recipes to use these ingredients and introduced them into the Samoan diet. These recipes now have become associated with Samoan identity around the world. However, the dark side of this diet is that these ingredients are also associated with diseases such as diabetes and obesity. Amanda also created her own version of doughnuts during the war to sell to the marines at the makeshift cinemas in her village. ${ }^{30}$

As in other theatres of war such as Kiribati and Papua New Guinea, the American GIs were friendly with local children and broke the ice using 'comfort items' such as sweets. Isabella from Tuasivi, who was ten years old at the time, vividly recalls the excitement associated with the American candies and wonders whether they were the reason she was sickly:

Masalo o le mea lena sa ou mai sela ai! - perhaps that is why I had asthma. The 'Baby Ruth' was a very popular candy mai i Amelika - from America. E le ta'ua e latou o se chocolate - they do not call it chocolate, it was always candies, it does not matter if it was Baby Ruth or other, they always call it candies. I remember they come in bottles, not plastic. They were in big glass bottles, with these little candies in them, all colours of the American flag, the stars, and stripes and there was also chewing gum. ${ }^{31}$

Isabella's new experience with wartime sugary treats was shared by other children. How the candies were packaged, 'all in the colours of the American flag, the stars and stripes' was representative of another deeper purpose. They served to remind the soldier of the basic enjoyment in life that was at risk of being lost to the enemy and thus to justify war to the volunteer soldiers.

Although imported sweets were not uncommon in the urban areas at the time, they were rare in the villages. The typical snack of a young Samoan, according to Sauni of Manu'a, was always a fruit or penu (shredded coconut) in a coconut shell. ${ }^{32}$ But the demand for candies rose because the marines kept giving them out. In the village of Leone, Amanda vividly recalls her introduction to the new craze for a 'sugar high':

One of the things we like was singing and getting together at night. The blackouts were still on but when you have the full moon we would get together and sing and play. One night, a marine turned up with cookies.

\footnotetext{
${ }^{30}$ Iuli, interview.

${ }^{31}$ Ryan, interview.

$32 \mathrm{~Pa}$ 'au, interview.
} 
Faatoa ota ila ai foi lea mea. We have never had cookies since we were born. But we ate these cookies, and we liked it and drank water from the bucket [action of hands cupping], there were no jugs then. There were many of us with our brothers, sisters, cousins and even our neighbours. On another night we did our pesega-singing again, and another marine came and gave us lollies. This was the first time we tasted the candy called 'Baby Ruth' and we all enjoyed them. There were a lot of other candies but this was the most popular one. Ia o le tala lena o matou. Ua fiafia, toe ai ma le lole! That is the story. We were all excited, and we ate lollies. E valaau lava Baby Ruth! Baby Ruth! ua pei a ua milionea! We kept calling out Baby Ruth! Baby Ruth! Like we were millionaires. ${ }^{33}$

Candies and other sweets created a euphoric experience for the young people. The local snacks of fruits and coconuts were no match for the Baby Ruth. Amanda's memories also reveal that these experiences did not happen in isolation; they were part of connected daily activities. An ordinary evening activity such as singing and playing with other children in the moonlight, suddenly became interesting because there was chocolate involved, not only for herself but for many others in her neighbourhood.

The GIs were synonymous with new food experiences. Isabella ate candies in all the colours of the American flag. Amanda had cookies and the Baby Ruth. Other food items soon followed. In Upolu, many soldiers shared their 'K-rations' with the locals. ${ }^{34}$ The marines lived amongst the Samoans and interacted with them using these comfort items. The villagers witnessed the marines' daily routines, including the 'chow' times when some of the young men would steal away with food for the neighbourhood children. Amanda remembered getting apples from one of the young men. 'Their mess hall was by the Catholic brothers' residence, where Aumavae is right now. You always see the maligi walk towards there all the time. But one maligi came and offered us apples. He had it under a poncho or whatever that thing was called. And of course, each of us all had apples ha ha! ${ }^{135}$

The items that were meant for the soldiers' consumption appealed to the Samoans because they were new and they appealed to the young people. Samoans began to acquire new tastes, including the demand for sugar, and formed new habits. The

\footnotetext{
33 Iuli, interview.

34 Alailima, Aggie Grey: A Samoan Saga.

35 Iuli, interview.
} 
soldiers were used to the candy, but it was novel to the local young people. As the novelty wore off, the candy became an everyday item.

The craze with sweets led children to follow the marines almost everywhere they went. ${ }^{36}$ Nanati remembered how the children of Nu'u'uli became familiar with the marines, enabling them to frequent the mess hall as young helpers. One of the new scenes at the Mess halls during 'chow' times were the young kids, mainly boys, who would call out to the GIs for their scraps to feed the pigs and chickens (traditional sources of protein for the Samoans).

Each of the kids had a tin, and they would line up waiting for the marines to finish then they would call. Ga'i! Ga'i! - Here! Here! [Pointing to their empty tins.] Later on, you would [call out] "Maligi over here!" calling the US marine out in English. They were quickly picking up the language. ${ }^{37}$

The usual daily tasks for young boys was to collect coconuts to feed the pigs and chickens changed during the war years. Many young boys seized the convenient opportunity at the mess hall instead of going to the plantations. Even the Samoan livestock had a new diet.

\section{Soap Suds and Shampoo}

Apart from the candy bars, other items highly demanded by the marines, and later by the Samoans, included tobacco, tooth paste and razor blades. Cooke writes that the all male panel in charge of the items required by military decided that nurses would need sanitary napkins, belts, assorted lipsticks, face powder, rouge and many other essential items for a woman's beauty regime and shampoo. ${ }^{38}$ Many of these commodities were unfamiliar to Samoans, but they soon became a part of their daily lives. Amanda Galea'i's shampoo incident is a good example.

One rainy day, my sister and I were weeding grass at our garden. A young guy [marine] who just returned from their morning drills in the bush had shampoo. Ae e lei iloa e au le mea e tau o le shampoo. [I did not know what shampoo was]. I thought it was whiskey because it was orange in colour. $\mathrm{He}$ said, 'Hi Banana!' and he poured some of the content of the bottle on my

\footnotetext{
${ }^{36}$ Lizzie Collingham, The Taste of War: World War II and the Battle for Food, (London: Penguin Group, 2012), 456-7.

${ }^{37}$ Savusa, interview.

38 Cooke, Chewing Gum, Candy Bars and Beer, 55-56.
} 
head and then headed towards the Convent where they usually shower. ${ }^{39} \mathrm{I}$ did not make a fuss because I thought it was an excellent oil. But then it continued to rain and felt my hair [touching her temple] and realised it had lather/suds! I got up and ran after him to ask what he has done to me. Ou tago i le ma'a togi ai ae sola! - I picked up a rock and threw it at him but he ran away. ... He later came back with another bottle and this time, it was green like mint. I saw him hide it in his pocket and said to me, 'I'm sorry!' Then he explained what shampoo is for and that it lathers the hair. After that, I was not angry anymore but was pleased because the other girls don't have shampoo. Before that, there was only the some called 'Natura' that we cut into small bars use that to wash the hair. And there was also the fisoa. ${ }^{40}$ Ua mimita ai la a'u ma ou fiafia ai. ${ }^{41}$

Amanda had a two-fold interpretation of her encounter with the shampoo. In the first instance it was a first-hand personal experience with a foreign product. The other more hidden interpretation implied by Amanda's comment is that the incident became a marker that separated her from other girls who 'don't have shampoo'. The multiple uses and applications of cultural items, in this case shampoo, indicate how personal agency can change the meaning and purpose of popular cultural items. Getting access to such objects became a quest for personal influence. ${ }^{42}$

John Carey, a marine, claimed that the children's fascination with soap suds brought them closer to the marines. ${ }^{43}$ The shampoo incident was an event that marked the interaction and exchange of material between the two people. It bears out Karl Marx's view that people make history, but not under the conditions of their choosing. Amanda's experience might seem insignificant, but it was a historic moment that shaped her interests. The use of shampoo became the new norm. During the war, Amanda's access to and use of shampoo set her apart from others. Amanda, in her personal way, made history when she discovered the usefulness of the shampoo for her personal purposes.

\footnotetext{
${ }^{39}$ Amanda was called 'Banana' by the marines who were at Leone during the war. The marines did not like the name 'Amanda' because they claimed it was German.

${ }^{40}$ Fisoa - the lather leaf (Columbrina Asiatica). Samoans used the fisoa to wash with.

41 Iuli, interview.

42 John Storey, Inventing Popular Culture: From Folklore to Globalization (Malden, Blackwell Publishing, 2003), $\mathrm{x}$.

${ }^{43}$ Carey, A Marine from Boston, 84.
} 


\section{Wartime Reading}

As well as bringing GIs, candy and other PX merchandise, the war also brought entertainment in the form of books and movies. Between 1943 and 1946 members of the United States Army Library Services (ALS) allied with a group of American publishers, librarians and authors to form the Council on Books in Wartime. Their primary objective was to supply American servicemen with reading material to help sustain morale and the drive to fight. The council created the Armed Services Editions (ASE) that supplied 1,322 titles in a variety of genres including the classics, history, comedy, westerns, romance and poetry. ${ }^{44}$ The ASE were paperback volumes, condensed to pocket-size and easy for the soldier to carry. About 122 million copies were shipped out to the various theatres of the Second World War, including the forward bases in Samoa. Many military historians have commented on the success of these literary weapons of war. The New York Times immortalised this wartime initiative by quoting an American serviceman in New Guinea applauding the books 'as popular as Pin-Up Girls' ${ }^{45}$

Poole's study of the ASE highlights that the reading material was designed for the soldiers to read and then discard. ${ }^{46}$ The council did not anticipate that the books would end up with the young Samoans who read some of the material they got from the marines they befriended for their own entertainment. This experience took them away from their reality into dream land, creating a desire to transform oneself, even if only for a moment. Many young Samoan women encountered romance novels, comics and Hollywood magazines during the war.

The exposure to 'romance' stories - referred to generically as 'Mills and Boon' - stands out in many participants' recollections. Winnie Laban recalls her late mother's memory of a marine who threw a little book into the rubbish. Out of interest her mother retrieved the book with the title 'Little Lolita'. She opened it and started reading, she knew how to read in English, and discovered a world of affections she had never

\footnotetext{
44 Alexander H. Poole, "As Popular as Pin-up Girls: The Armed Services Editions and American Print Culture, 1943-1947" (MA thesis, University of North Carolina at Chapel Hill, 2009), 4-5, 70-71. See also Christopher P. Loss, "Reading between Enemy Lines: Armed Services Editions and World War II," The Journal of Military History 67, no. 3 (July, 2003), 811-20.

45 Poole, "As Popular as Pin-up Girls", 58.

46 Poole, "As Popular as Pin-up Girls:", 70.
} 
experienced before. ${ }^{47}$ It is important to note that the ASE listings did not include 'Mills and Boon' titles as part of the 'keeping a healthy morale' scheme. Furthermore,

Nabokov's Lolita was not published until $1955 .{ }^{48}$ However it is not unusual to have this kind of conflation of wartime experiences with later experiences in the 1950s or 1960s. What is significant here is the association between reading romance stories and the wartime experiences. ${ }^{49}$

Amanda attested to the availability of these popular texts at Leone and how the young women enjoyed them during the war.

Apart from the Mills and Boon books there was also the comics. I liked them all especially the Times magazines. There were some that were not allowed to be brought in. But there was another magazine called Hollywood. That name was written outside cover. But for me it was always the Times magazine I like and the Readers Digest that I give to my mum to read, she likes them as well. That was what the nuns and the priests also read. $^{50}$

The availability of a variety of new reading material other than the school books and the bible stimulated the imagination and encouraged individuals to embrace new activities. As John Fiske suggests, 'the more popular the text, the more likely it is to be open, allowing the various subcultures to generate meanings from it that meet the needs of their own subcultural identities'. ${ }^{51}$ Isabella's recollection of her engagement with the new books during the war illustrates Fiske's point that individuals created new meanings and that literary experiences gave them an imaginary space to be themselves and escape their reality:

There was a lot of Mills and Boon but Papa did not allow us to read them. And the comics, there were boxes full of comics from Sapapali'i i maligi. Papa goes through the comics that we read and the ones we were not allowed to - I think the boy and girl things - Romance. Oh Mills and boons, I loved reading those because I was 13, I was starting to get interested in those. But Papa didn't allow it. I think it was very stupid at the

\footnotetext{
${ }^{47}$ Laban, interview.

48 Vladimir Nabokov, Lolita (Paris: Olympia Press, 1955).

${ }^{49} \mathrm{It}$ is of course possible that 'Mills and Boon' books may have been supplied by other sources or that they entered Samoa as part of the marines' personal effects.

50 Iuli, interview.

${ }^{51}$ John Fiske, "Television: Polysemy and Popularity," Critical Studies in Mass Communication 3, no. 4 (1986): 392.
} 
time. Today, it is natural for a girl or a boy to be interested in that. Not at the time. ${ }^{52}$

Despite the strict censorship at home Isabella still managed to get copies of these 'forbidden' books that dealt with taboo subjects that she could not talk to her mother about. Many soldiers often wrote to the ASE asking them to produce novels like Strange Fruit by Lillian Smith, which were more erotic or racey. The publishers responded: 'if the men want to read trashy novels then let's send them trashy novels. ${ }^{53}$ Strange Fruit was a 1944 bestseller that dealt with interracial romance. It was first published under a different name but was banned in many states because of the many steamy sex scenes it contained. ${ }^{54}$ These kinds of books introduced some of the young Samoan girls to the notion of sex. And this made Isabella more curious.

All the time. The girls at school brought these from the marines and we used to swap and I hide them. And you know in Savai'i, there are no flushed toilets, and it's a walk from the house. I go to the toilet with my Mills and Boon and read, read, read. After the toilet I would go under the tree close to it and sit down and read until you hear mama calling out to find where you are. You would go to answer but you made sure to hide your book carefully. It was always about the sex between a man and a woman - the romance. Ha ha ha! You know my mother never tell me these things but reading that raised my curiosity. I wanted to find out more and to try it out. And you wonder when you will experience it. Ha ha! That was it. Ia ae e leai foi gi tama aulelei -there were no good looking guys as well! Sometimes the stories were about a relationship that was not successful. But at least you get to learn that not every relationship can be successful. Its lovey dovey at times and love collapse at some other times. ${ }^{55}$

The idea behind the books was to arm the soldier's minds, but they also armed the minds of young girls and women. Reading the stories was also an emotional retreat from their different yet similar realities. Teenagers in Samoa who could access this material got a taste of what 'lovey dovey' relationships mean, subtly educating Isabella and many others about romance and expectations, and about sex.

\footnotetext{
52 Ryan, interview.

53 Molly Guptill Manning, When Books Went to War (New York: Houghton Mifflin Harcourt Publishing Company, 2014).

${ }^{54}$ Cheryl L. Johnson, "The Language of Sexuality and Silence in Lillian Smith's "Strange Fruit"," Signs 27, no. 1 (2001), 2-3.

55 Ryan, interview.
} 


\section{Motion Pictures and Beauty Culture}

The US War Department also screened films as part of the entertainment program for the marines to sustain morale and prevent boredom. Walter Wanger in 1941 wrote that the threefold principle behind the movies for the soldiers was to clarify the importance of the civilian's place and responsibility in society, to inspire the individual's confidence in the democracy he was fighting for and, lastly, for relaxation. ${ }^{56}$ The creed was the underlying reason why Hollywood movies were relevant in the war campaign. Wanger's famous claim that 'movies can be used on every front of the fight for morale' was perhaps true when applied specifically to the American GIs. ${ }^{57} \mathrm{He}$ did not anticipate the effects these motion pictures would have on the Samoans when they screened in the villages. The war department did not anticipate the potential social impact on the host society.

Although the movies were shown specifically for the marines, it was not difficult to invite the villagers as they were the everyday audience to all the military's activities. The motion pictures in the villages drew odd combinations of Samoans into the tents. The GIs, Samoan men and some women and children congregated to see American representations of fantasy and reality beamed glamorously onto the screen. Some of the women saw the 'aka kau ma aka kaupoe! - war movies and cowboy/western movies. Seeing movies was unheard of in many villages far from Apia and Pago Pago. Prior to the war the only place which showed movies in Western Samoa was the Tivoli Cinema in Apia. And as we have seen in chapter two the films shown in Apia were intensely censored by the New Zealand Administration in Auckland and Wellington before they were sent to Samoa. They were carefully selected to portray the invincible white protagonists. Any films showing any material that might incite an indigenous uprising against the administration were avoided.

The movies provided a first encounter with a world which many Samoans did not know existed. The films subtly encouraged individuals to adopt new attitudes. Amanda shared

56 Walter Wanger, "The Role of Movies in Morale," American Journal of Sociology 47, no. 3 (November 1941), 378.

${ }^{57}$ Wanger, "The Role of Movies in Morale," 378-83. See also; Michael Sturma, "Movies under the Sea: Film, Morale, and US Submarines During World War II," The Journal of Popular Culture 47, no. 6 (2014), 1213-1225. 
how her brother Otto responded when he first saw a film at the makeshift cinema that the marines put up in front of 'Le Mauga o Siona' - The Mount of Zion:

Oka! Oka e! (in awe) Over by Siona, the LMS church, was where they had the tent for the movies. It was those silent films. O le malie ia!-It was funny, my brother Otto first went to watch a movie. And there was a scene where a killer is coming with a knife. He (Otto) got up and ran thinking the man in the film was coming to get him. A couple of them kids had the same reaction. They were all scared. But the marines told them it was not real so they all sat down again and continued watching. Our generation loved it. They did it every night as well. We saw Betty Grable movies while the war was on. And they showed Dorothy Lamour in South Seas. Everyone clapped when the South Seas came on because those marines really liked the Polynesian women $!^{58}$

In many screenings around Samoa, the local population did not 'run away' but rather, embraced the films as entertainment.

Amanda's notion of Polynesian women during the war contrasted with the Hollywoodinfused and glamourised portrayal of 'Polynesian women' which shaped the American GI's view of Samoan women. ${ }^{59}$ The Hollynesian celluloid women, clad in sarongs, were military sanctioned doses of erotic fantasy. The older Samoan women were not oblivious to such publicly displayed fantasies and saw how the marines compared their young women to the likes of Dorothy Lamour, the embodiment of all the GIs' romantic imaginings. Alice remembered how she was compared to an actress in a movie that she had never seen: 'We heard all that, but we never go to those movies. Who was it that people said that I looked like her? She had long hair like mine. I was not allowed to cut my hair. But I cannot remember who it was, but they always say, hey when you let your hair down, you look like a lady [a Hollywood actress]. But that's all we just dream! Only dream about things like that'. ${ }^{60}$

The Samoan women saw how the marines tried to project these western perceptions on to them. As Amanda describes,

\footnotetext{
58 There is a tendency for people to give the short form of the movie titles they saw. Amanda's reference to 'South Sea' refers to 'Aloma of the South Seas' which came out in 1941.

59 Sean Brawley and Chris Dixon, Hollywood's South Seas and the Pacific War: Searching for Dorothy Lamour (New York: Palgrave MacMillan, 2012).

${ }^{60}$ Louise Mataia-Milo, Interview with Alice Mary McElhiney (Manurewa, Auckland New ZealandSaturday, April 4 2014).
} 
The palagi, a marine named Lucky who told us his real name is James, but he said he wanted us to call him Lucky because of the war. ${ }^{61} \mathrm{He}$ was the same guy who taught us the song. He was the one who met Tolei, a Samoan girl who had long long hair and always walks by our house to go to the shop. Lucky asked her what her name was, and she said Tolei. And he called out in a loud voice, Dorothy Lamour! Dorothy Lamour! The name stuck even after the war. Tolei had no idea who that was. She didn't understand because she did not go to school. She lived in 'Aoa. ${ }^{62}$ Her father is from 'Aoa. But I think because of her hair. She was very tall and slender and had long black hair. ${ }^{63}$

Tolei never have imagined herself as an embodiment of foreigners' obsessions, but Lucky did. As a representation of Dorothy Lamour's character, Tolei was also given the Hollywood fuelled meanings and expectations. The marines tried to accustom themselves to the new social environment by assigning what they were familiar with. Their use of glamourous women's names on the Samoan young women illustrates how some individuals used the magnetic power of the movies to lure some Samoan women into romantic relationships.

Regrettably, there are no lists of titles of movies shown by the armed forces in Samoa. But the Samoan women who watched movies saw these 'embraces' and the sexual connotations of the 'Hollynesians' that may have offered something different. ${ }^{64}$ The celluloid women portrayed a world in total contrast to the Samoan woman's world regarding values. They also certainly presented a challenge to the Christian Samoan pecking order of behaviour because they sent a message of confidence to the Samoan women encouraging them to be like those characters.

The movies influenced the way young women (those who were exposed to the films) saw themselves. As the war went on, young Samoan women gradually changed their conduct and appearance to 'heighten their sex appeal' by emulating hairstyles and fashion seen on the screen. ${ }^{65}$ Hairdressers began to appear around Apia and Pago Pago

${ }^{61}$ This may explain why it was difficult for some children of the marines to find their fathers because they went by names that were different from those in the enlistment rolls.

${ }^{62}$ Aoa is an isolated village on the northern east coast of Tutuila. What Amanda meant was that Tolei had no knowledge of who Dorothy Lamour was and why she was called that.

${ }^{63}$ Iuli, interview.

${ }^{64}$ Hollynesian refers to Hollywood actresses who played Polynesian women characters in Hollywood films. See: Patty O'Brien, The Pacific Muse: Exotic Femininity and the Colonial Pacific (Seattle: University of Washington Press, 2006).

${ }^{65}$ Kathy Peiss, Hope in a Jar: The Making of America's Beauty Culture (New York: Henry Holt and Company Ltd, 1998), 191-2. 
as Samoan women became the new and unintended consumers of the products and values promoted and sold by Hollywood. Alice saw a new vogue in Apia during the war.

[It was the] first time to have hairdressers. But you never hear about it. People do their own [hair]. They had it in their little Samoan house. And someone would have a hairdresser in there; I know when I go past it I saw a whole lot [of young women] going in, and I asked the question, what are they doing in there? And someone answered saying, 'Oh that is a hairdresser! You go in there, and you do your hair the way you want it because the Americans were there and the girls wanted to wear their hair like that other style you know where they put all their hair up instead of the Samoans always hanging their hair down.' When the Americans were there, they started having all these fancy hairdos, putting up their hair and that was the first time they had that hairdressing in those little faleo'o (small Samoan huts) different from the big family houses. These are the town girls - and you often wondered what the hairdresser would do to your hair. $\mathrm{Ha}$ ha! $!^{66}$

The interest with the way they looked and how they wore their hair was new to the Samoans. The 1945 census in Western Samoa itemised only one hairdresser in operation in Apia. This is the first time that a hairdresser specifically for women is recorded in Apia. ${ }^{67}$

The cash which flowed from the American marines as payment for washing clothes was another a stimulus for the transformation in Samoan women's beauty culture as women began to reinvent the looks they saw in the movies. Alice saw how the young women in Apia gradually changed the way they dressed: 'girls started wearing dresses, where they always used to wear just the ie lava lava and they started wearing all these fancy things going down the neck - things were changing. ${ }^{68}$ While items such as lipstick, shoes, and fashionable clothing are taken for granted by younger generations of women, these were things beyond the reach of most Samoan women before the war, even if they were available in the merchant stores. Cash enabled Samoan women to become consumers of these feminine goods during the war. Amanda remembers her older sisters and how access to money changed the way they dressed. The older girls were able to buy materials and dressed themselves nicely. Each had their own particular style.

\footnotetext{
${ }^{66}$ McElhiney, interview.

${ }^{67}$ IT 1287 EX 38/1/2. Census 1945., ANZ.

68 McElhiney, interview.
} 
This enabled Samoan women to access the construction of the Hollywood icons they saw in movies like Aloma of the South Sea and Sweet Rosie O'Grady. Amanda tells us that:

When the marines came, there was an awful lot of cash, money and they you see them Pulotu and her friends paint their lips and do this to their faces [imitate the act of applying the blusher on cheeks]. A lot of them kept their hair short and wanted to wear dangling earrings. Yes, they painted their eyes as well, and they were so beautiful because they now had lots of money. They even managed to have shoes whereas most of them never had shoes their whole lives. During the war, we saw a lot of high heel shoes for the first time here and the totini, silk stockings. They wore these here.

There were even gangs where the girls from [the next villages] would dress up nicely and then walk all the way here to wait for the bus or try to catch a ride to go to Fagatogo to dance. If not, then they stop and hang out with other girls over here. ${ }^{69}$

Isabella's experices with wartime popular culture contrasted with those of Amanda, Alice and Nanati because of her intimate connection to the people who were promoting the engagement. Isabella's story, as we have seen, was not typical of all Savai'i women because her family was part of the New Zealand Administration. The families of Faafouina in Vaega, Palepa in Safotu and Tauvaga in Lefagaoali'i had no direct engagement with wartime cultural material. The remote location of their villages sheltered them.

Isabella's mother was able to take control of wartime circumstances. She offered other women an opportunity to engage with wartime entertainment and try out the new looks with the means that were available to her. Isabella saw how the performances gradually altered the way people saw themselves.

The marines brought a lot of changes not just to our family but the whole island. The girls who come to dance are the ladies from the villages, some of them were female prisoners (who were serving their sentences here in the compound). The band members were all Samoan musicians - men, some of them were prisoners too, who could sing and play the guitar and ukulele. Mama would dress them up. E tago lou tina ave i ai ula ilaila! My mother would give them necklaces, the shiny ones to wear and they return it afterwards. E fa'a'aulelei ai i le siva - to pretty them up for the dance. They did not wear shoes not even jandals. Ta te ofo I le le tutu ai o gi maligi - I am surprised that some marines did not stand on [their feet]. But we were not looking at the feet. We thought that the girls were pretty! No

${ }^{69}$ Iuli, interview. 
lipstick! They used the red crepe paper on their cheeks, you know [as a] blusher. Ha ha, I remember there was a room behind our house where mama's house girls and the inmates use to do that. We watched them as kids doing that. I think e le'i faia laugutu i pepa because e wash off. I remember mama use the cashmere powder on the girls ha ha ha. E lulu i le lima (signal shaking the powder on the palm of her hand and then dabbing the face motion) Ha ha! But because we don't know any other girls, any other prettier girls, we thought they were all pretty. Some wear their hair up in a bun; some wear it down and some it's braided and brings it to the front of the shoulder. Ae sisiva lava ma nei maligi! - And they always danced with the marines! They enjoyed themselves. The boys [American servicemen] liked it too. I think, a break from the barracks and all the hard training. The siva was always during the night. In the end, everyone goes home. The ladies would wave goodbye to my mother and say 'see you next week'.

Despite the differences in the locality and the degree of 'pretty up' applied, the objective was the same; that is to invent the look which identified the new modern self. Amanda's reference to the 'gangs' of women who began to wander through the villages looking for their own entertainment indicates the development of the courage to step out for themselves.

The act of beautifying oneself as Kathy Peiss notes was a 'lightening rod for larger conflicts over female autonomy and social roles. ${ }^{17}$ Young Samoan women, much to the dislike of the older generation who preferred 'natural beauty', emphasised their womanliness by embracing the new vogues.

Nanati observed a new vogue with the older girls in Nu'u'uli which was very different from her own age group's wartime experience.

In this village, the usual wear for the Samoan ladies was the puletasi in those days. You never see any of them wear dresses up to here (pointing to the knees), but it was not long after the marines arrived that I saw them wearing pants, from the marines. This was their introduction to wearing pants, the ladies. They were not used it. Ia ae na ola ane lava e na o le ie! Since they were born it was always just the ie [lavalava]! $!^{72}$

Nanati also confirmed that young Samoan girls in their early teens still went around without any tops during the day.

\footnotetext{
${ }^{70}$ Ryan, interview.

${ }^{71}$ Peiss, Hope in a Jar: The Making of America's Beanty Culture, 7-8.

72 Savusa, interview.
} 
Before the war, beauty products were only available to women who had the means to acquire such luxury. Most of the Samoan women in the villages did not use foreign cosmetics. Nevertheless, the painted or 'made up' Samoan woman of the Second World War was a public declaration of individualism and self-liberation. Young girls and older women would often make fun of them because they were not used to seeing Samoan women with cosmetics. And according to Amanda, the older girls, like her sister Pulotu, were trying out these new things, similar to the female characters beamed out by the projectionists. ${ }^{73}$ The 'look' worked because it attracted both young enlisted men and officers. It was this look as well that became a point of conflict between the young women and Samoan society when some of the women left their homes and villages to live with or nearer to the American servicemen they befriended and consorted with. Some may have hoped that these newfound relationships would lead to a happy ending of social elevation.

But as discovered by some women, the images on the screen could also be deceiving. Summerfield and other feminist historians have long argued that the war was a leveller of society. ${ }^{74}$ In this case, it seems that the war provided the opportunity for an already unbound individual to exercise their self-determination; this posed a threat to society that had to be contained. There was an uneasy contest between the interiority of Samoan women's sexuality and the exteriority of political power. The war provided women with the space to decide whether to conform to Samoan society's expectation or go against such traditions. The hairstyles, the painted look, the dress and the entertaining were all critical parts of the declaration to be a singular woman who dared to be socially ridiculed.

Samoan attitudes towards women and popular culture began to change when women began to leave the security of their villages to consort with the soldiers. Several participants in this research indicated that this was an outrageous thing to do. Nanati related that the older women of her village blamed the younger women because 'they followed those marines around and they ended up sleeping together because of the

\footnotetext{
73 Iuli, interview.

74 Penny Summerfield, "Gender and War in the Twentieth Century " The International History Review 19, no. 1 (Feb., 1997), 4.
} 
money. ${ }^{75}$ These women became an embarrassment to the whole village and were often stigmatised.

Some of them, I'm embarrassed to say, e ta te ma'asiasi e tau atu, they became teine toso lau downtown. ${ }^{76}$ They wore beautiful clothes and were beginning to date some of the officers. Some of them went and lived with the officers and never came back home or tried to stay with other Samoan families who lived nearer to the maligi. ${ }^{77}$

The attractive made-up women with pretty dresses were a spectacle to see. To society, the 'look' at first was safe. However, when the pretty women made a conscious decision to use their agency it challenged the power structure and caused moral panic.

\section{Taimi o le Siva}

The United Services Organisation (USO) was a non-profit organisation that worked closely with the War Department to provide entertainment programs and movie screenings for the servicemen as part of the effort to sustain morale while the war was on. In Europe, the USO, the military and the local officials organised dances with the local women and other recreation activities to divert soldiers' from 'seeking amusement at unwholesome enticements often found in the communities they occupied. ${ }^{78}$ There were no known brothels in Samoa but the USO organised with local authorities for women's dancing groups to entertain at the weekly socials at the 'Pearl of the Pacific', the social club for enlisted men at their camp at Satapuala. Officers, on the other hand, socialised separately at the Casino Hotel at Sogi, at the Catholic Club next to the Mulivai Cathedral and at Aggie's Gentlemen's Bar just to name a few. ${ }^{79}$ Other venues included local restaurants at Magia, close to Satapuala. ${ }^{80}$

Samoans pride themselves in their hospitality in hosting and entertaining guests by displaying their dances. Many villagers eagerly set up women's dancing groups to entertain at the marine camps. Tuala was one of the young dancers from Vaiala who entertained the enlisted men and thought it was an enjoyable experience. Being a young

\footnotetext{
75 Savusa, interview.

76 Teine toso lau - a Samoan expression which often refers to women who have pre-marital sexual relationships.

${ }^{77}$ Iuli, interview.

${ }_{78}^{78}$ Cooke, Chewing Gum, Candy Bars and Beer, 28-29.

${ }^{79}$ Liua'ana, Samoa Tula'i.

${ }^{80}$ Isabella Stowers' Will, BBAE 1570 A645 1115/ P520/1953, ANZ.
} 
person, Tuala did not take much notice of what was going on other than following the guidance of the older women who led their group.

My earliest memory of the war was my siva at Satapuala. It was organised by Epi Enari, Karanita's mum. She taught classes for women at Malifa (Technical School) at the time. She organised it for us. It was a village group dance of young women from Vaiala. $\mathrm{Na}$ fai le matou siva laau and other. I remember we wore red and white floral uniforms. There were so many marines in the audience. Straight after our items we got on the bus that was organised for us and came back home. I did not. I was very young then. ${ }^{81}$

Tuala enjoyed the dances to entertain the marines. However, what was important to her was the effort by the women leaders like Epi who organised this opportunity for young women from Vaiala to see and be part of the war effort.

In American Samoa, many of the participants say that there were places in Pago Pago and Fagatogo where Samoan women socialised publicly with the marines. Outside of the camps, there were other places where the marines found entertainment. Saini and Saunia claim there were no canteens in the Manu'a Islands, but the church hall at Fitiuta held dances. ${ }^{82}$ Sometimes women either in their role as members of the aualuma or in their roles as women of the church capitalised on these socials to raise money for the church. ${ }^{83}$ Many showed off their new dance moves such as the jitterbug and the foxtrot which they had learned from the young American servicemen.

The dances were indicative of the process of change where the community acted like intelligent individuals who knew the source of money for development projects without leaving the village to look for funds. Amanda recollected how the aualuma which seldom met during the war organised a fundraising social which brought all the marines and the whole village together.

We had a social at the Catholic malae. Those were the days when we were still poor, but the aualuma was beginning to have money. They put up wooden posts and then these were surrounded with white fabric, about a hundred yards, forming a little wall, fence. I remember there was no electricity, but we had those small lamps hanging on the posts. Plus we had a full moon. My father and Avegalio looked after the money because the older ladies [of the aualuma] said they were honest. Inside here we all

${ }^{81}$ Hunter-Malietoa, interview.

82 Pa'au, interview; Milo, interview.

83 Iuli, interview. 
danced with the marines. At the same time tried to hide from my father ha ha! ${ }^{84}$

These 'safe fundraising socials' won the approval of the village elders because they benefitted the community as a whole, not an individual. Apart from the regular fundraisers there were also spaces in the village where the marines could socialise with the Leone young women. Amanda tells us that:

There was a house by the water where my friend Ruby's father put a piano he won from the Catholic brothers' raffle. That house turned into a dance venue for many young people to hang out. We used to make excuses to our father and ran away to that place for a dance. So whether there were marines or not, we would all dance at that house. Always the jitterbug! Sometime the foxtrot, the waltz. They (the marines) always want to cuddle... when they left we kept on dancing those moves. Lol. O le malie ia o Leone i lea vaitaimi. Leone was a funny place at the time. ${ }^{85}$

Unlike the very public access to dancing at Leone, the weekly socials hosted by Isabella's mother at the government compound at Tuasivi were exclusively for the entertainment of the marines.

My mother use to host a siva on Saturdays. We lived in a government house with a big veranda with two moli penisini and the Samoan girls would come with their ula mosooi with lovely fragrance and the marines would come who set up camp at our neighbour's land.... It was just a band of guitars and ukulele and they waltz, o le uosi a o le siva and sometimes there is a break with a Samoa girls siva samoa. No chairs, the marines would just stand around with folded hands and watch the Samoan girls dance.

Sometimes the marines would go up and play the instruments as well while the band has a break. We were inside the room with a glass window to look through. We were not allowed to come out. But I remember watching that! Ae maua ai kupe! They got money for it. Because e kago mama fai aga baking e o atu e sisiva ma fatau mea na. Mama used to bake, they [the marines] would come to dance and buy those. E ulu foi le siva i le tala Amelika! To get in, you have to pay as well, one American dollar. Ae o le kele ai ia o kupe a Mama! Mama made a lot of money - Ha ha! The dance finishes at 12 midnight, the marines would go back to their tents, the dancers would return to the village and we go to sleep. ${ }^{86}$

${ }^{84}$ Iuli, interview.

${ }^{85}$ Iuli, interview.

86 Ryan, interview. 
The jovial setting described by Isabella shows that a lot of preparation went into hosting such entertainment. Isabella, watching from the window, was the unseen observer of all this socialising between her mother's dancers and the marines.

Not all Samoans subscribed to the new trends brought by the war. In other villages on Savai'i and most of Upolu socialising was discouraged and village rules carried significant authority as seen in Matautu, Falealili and in Vaega at Satupaitea. Enthusiastic movie goers challenged the authority of chiefs and elders when the former objected to having movies shown in places that were traditionally viewed as 'sacred ground' and seldom used except for cultural purposes. At the same time, there were others who preferred to keep the marines' social activities such as dancing and movies away from the centre of the village. The makeshift cinema moved from the middle of the village in Leone to further inland towards the bush. The older people did not want to let other villages know that that they had succumbed to imported influence and allowed their young men and women to socialise together in spaces that were sacred. As described by Amanda:

Our generation enjoyed these movies but Siaumau [an influential elderly chief] said to take the movies away from the centre of the village into the bush. And they did! We always asked my father if we could go. Otherwise we would make an excuse to visit one of our aunties who knew how to bake and lived closer to where the faletifaga was. We did not care less with the silent movies. ${ }^{87}$

Conservative cultural and religious views hindered other individuals' engagement with popular culture. The older generation were aware of the relationships which inevitably began to develop between Samoan women and the GIs. Older women unassumingly warned young women in the aualuma about these changes in behaviour. They complained and scolded them at the aualuma's meeting as witnessed by Nanati, 'Sa matua otegia lava e lou grandma ma le faletua o Soliai le Tinifu because of what they were doing with the [maligi]. ${ }^{88}$ In other villages, older women could be heard trying to stop their young from frequenting these popular events.

Many of the old women had a go at the young women. You can hear them oke - telling off in Samoan over here. Often I hear them say, 'Soia ia! Aua

\footnotetext{
${ }^{87}$ Iuli, interview.
}

${ }^{88}$ Savusa, interview. 
le tata'a ae omai i le fale! - Stop this at once! Do not wander off but come home!' But many did not care about these complaints or warnings by the older ladies. But there were also some of the older ones around 60 or 75 [years old] joined in the dance and sing here Leone. Many of them around 75 all came to dance and sing. ${ }^{89}$

Nanati recollected that, 'O le magaia ia o le olaga i maligi! Life was great with the maligi'. Nanati described how many Samoan men and only a few women flocked to Nu'u'uli. Often young women felt frustrated because their mothers or grandmothers stopped them from going to these popular gatherings. Young girls such as Nanati were told to avoid walking around the village in case 'e toso oe e se maligi - you might get pulled by a maligi!'

Here on our land, [pointing to the back of the house] was where they had the place for the movies - the faletifaga - cinema o ga'i! It was always filled by the Nu'u'uli people because it was an open tent. Anyone can go in. they would watch movies about wars, sometimes they had a lot of movies with a lot of singing and dancing and sometime there were the cowboy movies. They did not have those other movies. That was after the World War II. There was the man, Bing Crosby. Oh and that beautiful lady named Dorothy Lamour. She had brown hair. But I was always not allowed to go. My Grandmother would try to tell a fagogo - story to us while all the time we wanted to go to the movies. ${ }^{90}$

Many parents did not approve of young people's contact with the marines through the popular dances. Especially since many of the American GIs were married men and many young women were beginning to develop relationships with them. Amanda related how she may have frustrated her father at times when she decided to go to the dances without his permission.

E sosola! E sosola! - We sneaked out. We ran away! I had two cousins who slept here [at our house]. My father sleeps on the other side of the house opposite us. He always rocks his foot like this [signal] that tells us is awake. When it stops that is how we know he is asleep. Then we crawled out of the house and go to the siva. The clothes we slept in we also danced in ha ha! One of us had to hold our sheets so we take turns in dance. Yes we took our ie afu. Sometime you keep it under your arm and dance. My father who always sleeps with his torch and five small rocks in case a moetolo comes, would wake up to find we were not there. He would send Otto to where

\footnotetext{
89 Iuli, interview.

90 Savusa, interview. Fagogo - story telling. This was a favourite pastime activity for Samoan children. The adult, usually the parent or grandparent would tell a story to the children with the purpose of teaching morals, imagination and skills to the young ones. Since the introduction of cinemas, and other night entertainments the fagogo became less and less.
} 
the sound of the piano was coming from to summon us home. He did not really scold us, because we obeyed and come home. That is what we did with Saili ma Tautala - we always sneaked off ha ha. Pulotu was always allowed because she was much older. ${ }^{91}$

The older people were always suspicious and were worried about their young people getting caught in this wartime fever. But some young people were already aware of the differences between them and the marines. Amanda learned that most the GI's were married men. 'Sr. Mathew said to me when the war first started, "those are all married men" so from the beginning I knew that most of them left their wives back home and come here for the war. I kept that warning in my mind throughout the whole time. They were all married men! ${ }^{92}$

When reflecting on their experiences, all the informants remember how the wartime objects for entertainment that came with the marines made life interesting for all of them regardless of where they lived. Many young people like Amanda and her cousins tested their parent's patience and the degree of their budding independence as individuals.

The frame of popular culture provided my interviewees with a unique opportunity to reflect on their lives as young women during the war. Their reflections show that engagement with popular culture meant different things to different people in the community. The different paths which Samoan women took in their engagement with wartime popular culture meant that they interpreted their experiences very differently from each other. Samoan women entered the frame of wartime popular culture from different angles and experienced the wartime period on different terrains. The different veins of social capital to which they had access, their pre-war lives with the church and their geographic locations, shaped their terms of engagement with the new wartime culture. These unique local historical experiences were international experiences as well as gendered experiences and had a bearing on how women understood the social and historical impact of the wartime era.

The narratives illustrate how the war harnessed women's resourcefulness and made life before the war seem backward and uninteresting compared to the verve ushered in by

${ }^{91}$ Iuli, interview.
${ }^{92}$ Iuli, interview. 
the American servicemen and their material culture. Perhaps Amanda's comment best summarises what Samoan women must have felt about the changes in their lives when they engaged with wartime popular culture: 'E lei mafai e se isi ona taofi, ua alu ma le atoa suiga ua o'o mai! No one could stop it, the changes were in full speed!' ${ }^{93}$

The examination of Samoan women's engagement with the popular culture that came with the marines has shed light on the subtle connections between the consumption of wartime pleasure in its many forms and social transformation. At the same time, it shows that people make history in the most ordinary of ways. That is, mundane events can have historical weight and effect social change. Things that may seem ordinary are themselves great historical moments that shape individuals' responses and their relations to each other.

The engagement with new foods and commodities shows how even small objects could be saturated with cultural values and symbolism, far greater than their practical functions. American cash became a sought-after currency to sustain Samoan consumption of American culture. The use of American products and the development of beauty regimes, fashion and music led to the subtle Americanisation of the Samoan Islands.

Popular culture was an ecumenical force which drew different people into spaces they did not usually share, generating new social dynamics. The singing in the moonlight that sent young children into a sugary trance, the makeshift cinemas and the siva nights brought the marines, children and women, young and old, as well as chiefs, to socialise together. Social boundaries became blurred. The popular cultural activities concentrated people's emotions. This ecumenical force pulled American marines and women into intimate relationships. The sexual relations that came after remained elusive but we know that they resulted in the birth of many Samoan children with American heritage.

93 Iuli, interview. 



\section{Chapter Six. Samoan Women's Wartime Sexual Encounters}

Samoan women's sexual relations with the American marines resulted in the birth of many Samoan-American children. This aspect of women's wartime lives is laden with uncertainty and emotional experiences, especially for the women and children concerned and is therefore difficult to talk or write about. Samoan society's discontentment, then and now, has been reflected in the way wartime sexual relations are remembered. That discontent sometimes includes the silences punctuated with the intonations of whispers and the sneering facial expressions that I described in the first paragraph of this thesis. This kind of remembrance normalised the widespread misconception that equates all Samoan women's wartime experiences with illicit sexual relations with members of the armed forces.

Samoan women's sexual encounters with US servicemen during the Second World War were neither ubiquitous nor inevitable. Sexual relationships did sometimes lead to the birth of the children, but this outcome does not provide the full picture. Athough the New Zealand and US officials claimed that Samoa had one of the highest rates of wartime births, there are no official statistics on the number of women who had sexual relationships nor an exact count of the number of children born. ${ }^{1}$ Sexual encounters involved a mixture of consensual and coerced acts. A deeper understanding of these has the potential to completely change the existing view of women's wartime intimate relationships. One argument that this chapter makes is that Samoan society's attitude towards women changed because of the high incidence of pregnancies. While many women who had war babies were stigmatised, the women who had sexual relationships with the marines but who did not have children escaped the sentence of social judgement.

This study maintains that talking about wartime sexual experiences, although uncomfortable and unusual in any circumstance, is a significant pathway to understanding clearly why this aspect of our women's wartime past has been remembered in a particular way. The level of Samoan women's understanding of sex

\footnotetext{
${ }^{1}$ James Michener, "History of US Naval Station, Upolu, Western Samoa," 1945, RG 313-58B-3061NA SB, cited in Mothers' Darlings by Judith Bennett and Angela Wanhalla; Inspector of Police to Sec to the Administration, 12 February 1946, EX 38/1/2 ITI 287, ANZ.
} 
and bodily knowledge also needs to be taken into account as well as the perceptions of the American seviceman.

The chapter has three main parts. After a brief discussion of interethnic relations, the first section focuses on the women's narratives and their reflections on the range of experiences they had as young women during the war. One of the questions examined in this part of the discussion is to what extent did Samoan women's engagement with wartime popular culture influence these encounters. The second part of the discussion focuses on the women's reflections on their understanding of bodily knowledge and the fundamentals of sexual experience. Attention is paid to the critical contribution of women's institutions such as the aualuma which cultivated young women's sexual knowledge. The assumption here is that understanding bodily experience orders behaviour and informs personal agency including the decision to participate in sexual activity. The third part of the discussion looks at how women's wartime sexual encounters impacted on the social and moral fabric and exposed society's perceptions of sex as a mechanism of power and control.

\section{Inter-ethnic relationships and illegitimacy}

There is no way of knowing all the types of sexual encounters that happened in Samoa during the war. What is known is that women had sexual encounters with the American GIs because there were babies born and fathered by the 'maligi o le vaega au - marines of the (US) Forces. ${ }^{2}$ We have not yet considered very much the Samoan women who had sexual encounters, either consensual or coerced, but who did not have babies. Then there are the clandestine relationships that occurred amongst the Samoan and "halfcaste" population. Samoan society did not stop functioning when the American forces took over. Samoans, "half-castes", and foreigners coexisted during the war and engaged with one another in a variety of ways.

Sexual encounters with foreigners were not new in Samoa. The pre-history of Samoa is punctuated with intermarriage between Samoan women and neighbouring islanders from Tonga, Fiji and even the smaller islands of Futuna and Tuvalu. Intermarriage between Samoan women and traders in the nineteenth century trading and whaling era

2 Mataia-Milo, "There Are No Commoners in Samoa," 54-5. 
produced individuals such as Emma Coe, Phebe Coe, Margaret Young (who became the Tui Manu'a), Private Allen Williams, O.F. Nelson and the famous hotelier, Aggie Grey. ${ }^{3}$ There were many others scattered around the archipelago. Inter-ethnic relationships became gradually accepted over the decades. As discussed in Chapter two, the colonial powers' obsession to control marriages between Samoan women and foreigners did very little to stop miscegenation. By the First World War there was already a growing population of mixed blood Samoans, afakasi/ toto lua - half-castes/ people of two bloodlines in the two Samoan territories.

The US Command intelligence report on Western Samoa's ethnic profile, as shown in Table 1, placed emphasis on the 'township' of Apia as the location where most of the part-European population resided. The report anticipated that any opposition to the US command would come from the "half-castes". About 50\% of the "Full European" sector of the population were members of the New Zealand administration and foreign merchants who had operated in Samoa since the turn of the century. Nearly half of the "half-caste" population according to the statistics lived in Apia.

\footnotetext{
${ }^{3}$ Damon Salesa, "Troublesome Half-Castes": Tales of a Samoa Borderland." MA thesis, University of Auckland, 1997; Salesa, "Emma and Phebe"; Alailima, Aggie Grey, a Samoan Saga.
} 
Table 1 Ethnic Profile of Western Samoa in comparison to the township of Apia, $1942^{1}$

\section{Ethnicity}

Full Europeans

Persons of mixed European and Samoan Descent

(Legally Europeans)

Samoa natives

Chinese labourers

Other Chinese

Melanesian labourers

Total

\section{Apia Western Samoa \\ including Apia}

200

1,250

4,900

24

10

16

6,400
$\%$

60

43

8

8

21

${ }^{1}$ US Naval History Division, "US Naval History of Western Samoa," Micro-MS-0850-1, ATL, 24. 
Inter-ethnic relationships and illegitimacy were not new phenomena. Over the years, society had accepted the children born out of wedlock (in the Christian sense) through the slow process of social absorption. Governor Bryan wrote in the mid-1920s that 'Traditionally, a child born out of wedlock labours [under] no disadvantages, and an unmarried mother is soon forgiven by her family and the community. ${ }^{1}$ The governor's observation suggests that illegitimacy was not a contentious subject.

Marriages in the Samoan perspective are important channels through which families are connected to chiefly titles, prestige and political influence. Hence the importance for Samoans of knowing and recognising both maternal and paternal ancestries. Even in polygamous Samoa, children were acknowledged by the paternal family through the cultural rituals at the time of the child's birth. For most of the $19^{\text {th }}$ century there was never a question about the children because they were all claimed by the extended family, the aiga. The concept of illegitimacy was introduced only with the concept and practice of monogamous Christian marriages.

Samoan women's sexual relations with members of the armed forces resulted in an explosion in the number of illegitimate children throughout Samoa. Michener estimated that about 1,600 children were born from wartime relationships. ${ }^{2}$ Kennedy has estimated that 'approximately a thousand children of mixed ethnicity were conceived during the height of the war years. ${ }^{33}$ The villagers' estimates suggest that the number of children born out of wedlock from relationships with Americans during the period between 1942 and 1946, amounted to almost 2000. The Pacific Island Monthly reported that registered births for 1945 was 2161 while the deaths were recorded at $647 .{ }^{4}$

Bennett notes that both the military and colonial governments had specific instructions from the US High Command that servicemen could not marry women of any ethnicity without the commander's permission. ${ }^{5}$ Despite military regulations, some American GIs who had relationships married their Samoan partners 'in the Samoan way', which was

\footnotetext{
1 "American Samoa - a General Report by Governor H.F. Bryan - October 1926." ACFX 8294 W1510 IT A3 3/15, ANZ.

2 James Michener, "History of US Naval Station, Upolu, Western Samoa."RG 313-58B-3061, NARA;

Mataia-Milo, "There Are No Commoners in Samoa," 54-5.

${ }^{3}$ Kennedy, The Tropical Frontier, 98.

4 "Social Conditions" Pacific Islands Monthly, 17 December, Vol XVI, No. 5, 32

${ }^{5}$ Bennett and Wanhalla, ed. Mothers' Darlings of the South Pacific, 18-22.
} 
still illegal. Some individuals penned their affections in favourite books such as bibles as a pledge of their love for each other, like the case of Homer and Vaofefe Willess in 1942, American Samoa. ${ }^{6}$

The Western Samoan census in 1945 enumerated illegitimate 'half-castes' with a specific count of 252 'American G.I.' children. ${ }^{7}$ The difference between the census and other statistics, according to the NZ administration official, was that 'a great total of such births have not been adequately given but have been included in Samoan native schedules and cannot therefore be traced. ${ }^{8}$ The pulenu'u (village mayors) classified many of the American-Samoan children as 'natives'. Similar problems had also occurred in the 1936 census where illegitimate half caste persons were classed as Samoan Natives. Chinese-Samoan children living with their Samoan mothers in the villages were given Samoan names and included in village schedules prepared by pulenu'u. ${ }^{9}$ In short, there was no special register of Samoan children fathered by the American marines during World War II and there were already children in American Samoa from similar pre-war relationships. ${ }^{10}$

The large number of births strained the processes whereby children normally were absorbed into society. In the absence of the father, the ceremonial acknowledgement of the child and the social obligations and responsibilities of the paternal side in raising the children remained incomplete, which is frowned upon in Samoan culture. Moreover, the children were a constant reminder of a time when society had let its guard down on social and moral mores. They were markers of when women exercised their personal agency and crossed social boundaries. The children became synonymous with failure and Samoan society, in a moral panic, treated the women who 'betrayed the order' as scapegoats for this shameful period.

It is a natural human behaviour to draw on past experiences to find meaning in new encounters. But in the absence of experience, the new encounters becomes new

\footnotetext{
${ }^{6}$ Mataia-Milo, "There Are No Commoners in Samoa", 65.

${ }^{7}$ Census 1945. IT 1287 EX 38/1/2, ANZ.

${ }^{8}$ Census 1945. IT 1287 EX 38/1/2, ANZ.

${ }^{9}$ Inspector of Police to Secretary to the Administration, 12 Feb 1946, IT 1287 EX 38/1/2, ANZ.

Mataia-Milo, "There Are No Commoners in Samoa", 54-5.

${ }^{10}$ Iuli, interview. Amanda refers to Leone children born in 1937 and 1938, fathered by Navy servicemen stationed at the Dispensary at Leone.
} 
experiences that create anxious emotions at first, until they make sense. ${ }^{11}$ Society's displeasure and stigmatisation of the women is part of the same process. The scale of the situation placed everyone under pressure. The young men and women who were learning to be adults, the older men and women who were policing the once solid social boundaries, the military and local authorities who had their regulations to adhere to. There were many possibilities that may explain people's actions and reactions.

The US servicemen were wartime sojourners who were on their way to the front. Samoa was a transit place for them. The wartime reality for the soldiers was that their lives could end at any time, so there was not always a sense of obligation or responsibility tied to sexual encounters and their after effects. Some individuals' relationships were more serious than others; they tried to provide for the child. ${ }^{12}$ In some cases the marine returned and formally married the Samoan woman after the war. $^{13}$

\section{Narratives of sexual encounter}

Joan Scott in one of her influential works stated that 'when experience is taken as the origin of knowledge, the vision of the individual subject (the person who had the experience or the historian who recounts it) becomes the bedrock of evidence on which explanation is built. ${ }^{14}$ Scott's point is useful for thinking about Samoan women's wartime encounters. The key component of knowledge for an indigenous society such as Samoa is the communication of knowledge by observing others and by doing, but this is not the case with sex and bodily knowledge. This, I believe, makes bodily knowledge a highly politicised terrain. The general assumption is that knowledge shapes action, yet even in the $21^{\text {st }}$ century the topic still makes for an uncomfortable conversation even amongst women.

Knowing the number of children born to US servicemen raises further questions about the nature of these sexual encounters. Were these sexual relations consensual or were they coerced or were there other influences that shaped the trajectory of Samoan

\footnotetext{
11 Scott, "The Evidence of Experience." 773

12 Mataia-Milo, "There Are No Commoners in Samoa," 61.

${ }^{13}$ Mataia-Milo, "There Are No Commoners in Samoa," 66-73.

14 Scott, "The Evidence of Experience," 777.
} 
women's wartime sexual encounters? To find an answer to these simple yet complicated questions, one must first explore the kinds of sexual encounters that the women who chose to share their wartime lives described. The narratives presented by the women interviewed give their understandings of their own experiences or those they were aware of. Their stories are the evidence of wartime agency. They are the muses of their own lives in wartime Samoa.

\section{Shadows in the night}

During the war, Alice and other girls boarding at the Convent School (now St. Mary's) at Savalalo witnessed from an elevated yet secluded balcony the clandestine relationships and exchanges of affection that took place in the dark of the night. Alice saw shadows in sexual acts and internalised what she witnessed and did not say anything to prevent upsetting the order of things. The young women created an appearance of 'virtuous self' to keep the 'cultural and religious' status quo while at the same time they were beginning to experience sex by observing from a safe distance.

We used to see things going on at night. 8o'clock we go to bed, say our prayers and we go to bed and we just whispered to each other and wait until sister is asleep and then we sneaked out on the veranda outside. There was a very high fence, hedge. On the other side of the hedge, there were boys and girls doing bad things or whatever they were doing over there. Of course, we can see from the top and we had to be very quiet in case sister heard us. And then we saw all these things that we didn't know that part. Because we saw them hugging and kissing and lying down and then. [silent] [Question: Were they having sex?] Yes! We never make a noise and then we sneaked back to bed. ${ }^{15}$

The shadows and the dark gave anonymity to the men and women, but the observers on the convent balcony could clearly see the sexual activities that went on. Although Alice at first did not understand what she saw, the acts registered in her memory and it became the bedrock of her knowledge about sex. Conditioned by the Christian principles that governed her upbringing, even in her reluctance to say the word 'sex', and without any prior sexual experiences of her own, Alice then cast the moral judgement that 'they were doing bad things'.

15 McElhiney, interview. 


\section{Cheeky Dancing}

Some sexual encounters followed meetings at the 'siva' where the young soldiers were sexually stimulated by enticing choreographed performances. This is where women's engagement with the new wartime popular culture enters the picture. The village dancing groups, like the one that Tuala danced in, and candies led to the beginning of intimate relationships between some marines and Samoan women.

Many of the informants were children at the beginning of the war and as such were often ignored during adult conversations and social activities. They had the freedom to move unrestricted amongst the groups because of the assumption that children are too young to notice or make sense of things. Isabella, for example, was only 10 years old when the war started. Three years later she was already a young adult, observing the preludes to sexual encounters.

Perhaps if we were a bit older it would have been a different story. We were always locked in the bedroom. Mum always say, 'Don't come out, stay in there!' The three of us. But you know the windows, there are no lights in the bedroom but the light from outside comes through the window, we take the curtain off and we could see the siva. Mama would come to see us in the room and we were watching through the window. It was alright with her. Even papa as well, he would come and ask us, 'Are you alright?' E le moemoe e faitatala e o e tilotilo - we don't sleep, we wanted to watch. We were allowed to watch. ${ }^{16}$

From the window of her bedroom, Isabella watched the dances hosted by her mother. She saw a new world revealed to her. A new world that she did not understand. Isabella recalled how they sometimes saw scenes that were more than dancing, and this fascinated her. Their seaside veranda at the government compound by Cape Tuasivi was transformed every weekend into a stage where the dancing and drama of romance and emotions were exchanged. It was here that Isabella received her first lesson in 'love'.

I saw a maligi kissing a girl, and you think, Auoi - wow! Ha ha, you know real embrace and making love, real proper kisses! That is how I found out about kisses because in Savai'i, e leai gi tifaga. There were no movies that you know about 'make love' or anything! This was my introduction to the kiss between a man and a woman - Looking at the marine and the Samoan lady. I saw it, and I said to Sisa, 'auoi vaai i le maligi ma le teine la e kisi! Oh my, look at the marine and a lady kissing! Sisa said 'Auoi! Auoi! - Oh

\footnotetext{
${ }^{16}$ Ryan, interview.
} 
my! Oh my!' She [Sisa] thought the girl was lucky getting kissed by the marine. My brother was very young. And he would ask, 'O fea? O fea?' $\mathrm{He}$ didn't know because he was about 8 or 7 , he was very young. Ha ha ha! I was 10 at the very beginning. ${ }^{17}$

Isabella was awe-struck when she saw an intimate moment between one of her mother's dancers and a US marine. Although the act Isabella witnessed was not as erotic as the shadows having sex in the dark that Alice saw, Isabella took it as 'a real embrace and making love'. ${ }^{18}$ The two young women saw the 'acts' but had different responses.

The allure of the dances and mixing with men was something very new in Samoan society. Except for village events, men and women seldom socialised together. Some of the girls wanted to join dancing groups so they could do their part in entertaining the marines. Most parents did not approve of this trend. Isabella recalled how one young woman preferred to suffer the consequences so she could socialise with the young men from the armed forces.

But there was a girl; I forget her name now, but she always usesd to get hidings from her mother or father because she was not allowed to come to these socials. Ae e sola mai lava - she ran away to where we were. O ia lega e kisi kisi maligi! She was the one who was always kissing the marines! ${ }^{19}$

The dances that Isabella enjoyed with her two other siblings were at the New Zealand administration headquarters, a private space away from the villagers and away from the clergy's criticism. The privacy made the dances a lot more daring and coy in contrast to the entertainment found in more public spaces in Apia, Leone and Nu'u'uli and other parts of the Samoa Islands.

There were Samoan women who knew how to hula; I do not know where they learned it from... but their dances were all Samoan [and] mama dressed them. E amata a na siva le teine - The lady would begin her dance I remember this, the woman's ie lavalava is down to her knees in length and her kiki e i luga i'i - the grass skirt is up to here [signalling the length of the skirt at the thighs]. My mother sews these shorts for her [to wear inside]. So she would siva siva and then she unhooks and drops the ie and dances with just the [kiki]. Then you listen to the roar of the maligi applauses, clapping and whistling. ${ }^{20}$

\footnotetext{
${ }_{17}$ Ryan, interview.

${ }^{18}$ Ryan, interview.

${ }^{19}$ Ryan, interview.

${ }^{20}$ Ryan, interview.
} 
The howling applause signalled the marines' approval of the performance. Perhaps the live performance outclassed the celluloid women (the Hollynesians on the silver screen that they were unable to interact and become intimate with) because the weekly dances and these types of performances created a possibility of having sex with real women. These specific types of dances raised everyone's hopes.

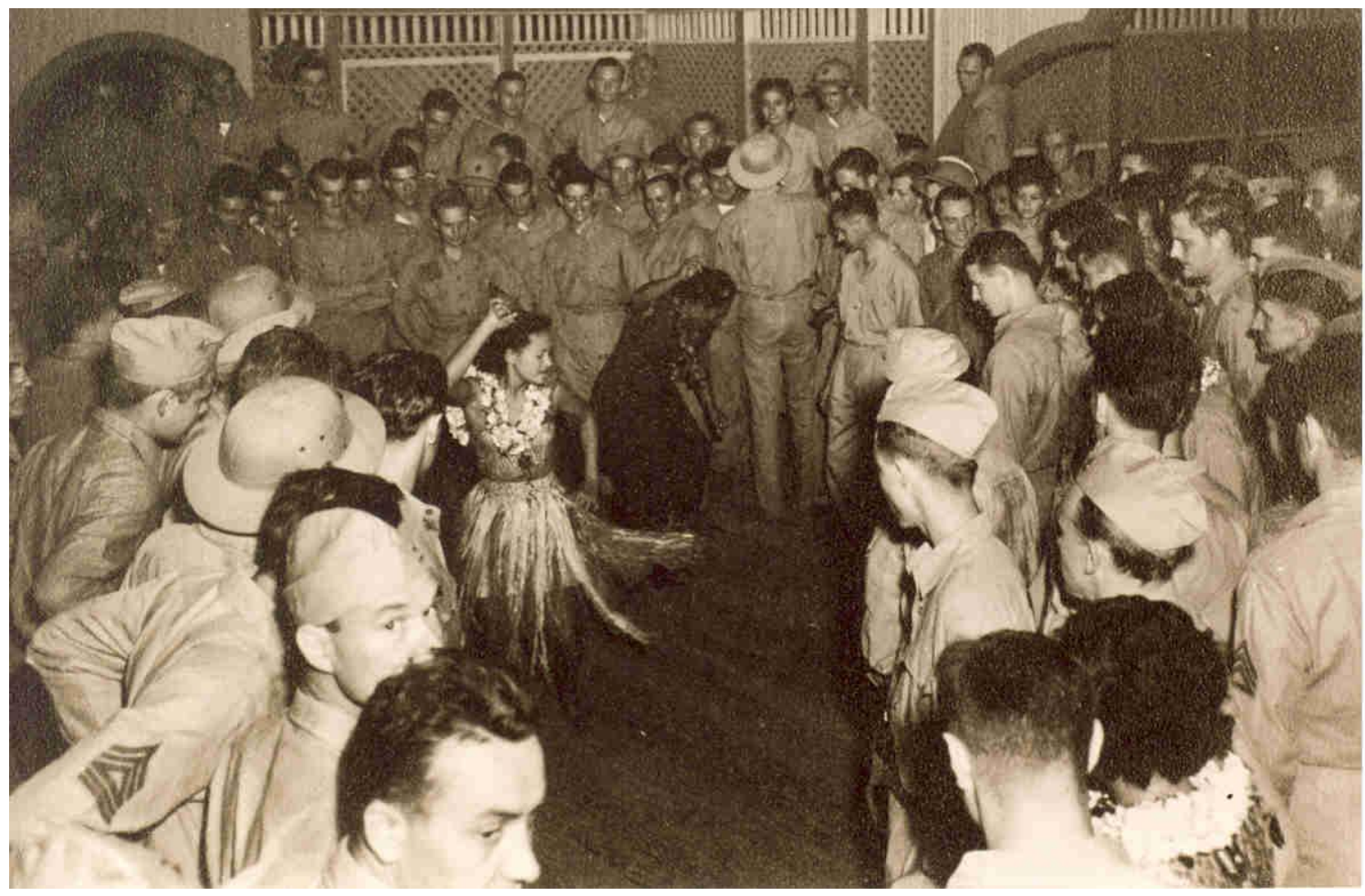

Figure 14 The Cheeky Dances? Entertainment at the 'Pearl of the Pacific', an entertainment hall for enlisted men at the US Marines Camp at Satapuala, Western Samoa during WWII. (Source: National Archives, MESC, Malifa.)

For the hosts, the dances were part of the entertainment efforts by a New Zealand official to raise morale for the troops. Isabella's mother was the wife of a government official. The money collected at the door and from the food stall would help run the household and pay for the band and the girls as well. For the dancers, keeping in mind that the Samoans traditionally were status conscious, perhaps some people imagined that in these budding relationships there was the chance of perhaps marrying a marine, though no one would have admitted entertaining such thoughts. For young girls such as Isabella, there was hope that future experiences would be as enjoyable as what she saw at the dances. For the marines, the dances were an entertainment that filled the hours as they counted down the time to their deployment at the front in the Solomon Islands or 
in Papua New Guinea or their return to the US. Any chance to enjoy the physical pleasures on offer was welcomed with open arms because it might be their last.

This lady who danced using the kiki, I remember mama used to call that dance, 'o le sausaunoaga a le tamaitai ma le siva a le teine - A lady's performance and a girl's dance', dancing in a cheeky way! E pei e taufa'alili - Like a teasing way, that there is a meaning to her actions towards the guys. Well, the papalagi know what the actions were, there was a sexual nature to the dance, o lea fa'atoa ou iloa (I just know now) ae o le taimi lena ou te faapea, poo lea le uiga o le la mea - but at the time I always wondered what the meaning was. ... That lady who used to do that dance was appealing when she did it while we were watching. And all the other girls were very good at dancing. Some of them were plump but were very graceful. Well I thought they were. I don't know how they felt about it, I was young but I know and remember, the whistles and the clapping when she dropped the i'e and danced with just the kiki. And remember [too] it was not just the panties she was wearing; she had shorts inside. And the top was apaau pe'a [strapless]. The Samoan women, were mature and didn't wear any papa susu [bra on their breasts]. No bras at the time. Mama used to sew the strapless with elastic at the back that they can just put on and the elastic holds everything at the back. ${ }^{21}$

Isabella's memory provides us with insights as to how young girls understood these performances. Although she was unaware of the carnal codes inscribed in the shows in her first teenage year, Isabella held on to these powerful memories. The choreographed performance in the actions and the dropping of the i'e lavalava, the way they dressed, and the two-part act as depicted in the name were all sexually evocative and mimicked the fantasies in the movie screens. However, participating in such exotic antics for entertainment had larger resonance than the momentary thrill it delivered. These 'cheeky dances' as Isabella called them epitomised how, during the war, some individuals capitalised on playing up the stereotypes of 'South Seas' fantasies. Indigenous women engaged in performances, knowingly, slowly transgressing the boundaries of moral codes as part of the entertainment for the marines' pleasure.

Reflecting on the images and memories that she had kept for over 70 years, Isabella was confronted with their underlying meanings. She was a close observer of the social encounters at the dances her mother hosted. Her wartime experience, as a young woman, an observer, as a storyteller becomes the historical lens that connect the realities of the wartime past to the present generation. Reflecting on her life during the

${ }^{21}$ Ryan, interview. 
war, Isabella does not acknowledge the significance of her role as a historian in the ordinariness of her life.

To me now, looking back at the experiences, it was an experience. But at the time, I was innocent. I enjoyed watching them. I enjoyed looking at all these many palagi. Oka Oka ae o le aulelei ia o nai tama; they were handsome young men. And some men as old as Papa at the time. Ae e leai lava so ta ita manatu i ai like e te manao i ai - and I never had any thoughts then that I would like them as a boyfriend. ${ }^{22}$

Women's accounts of their lives negotiate the contradictions and the discrepancies between the self and the relationship with others. Isabella's account allows us to discover a multitude of roles and situations that were not known before. She tells of her mother as a home maker, an administrator, a village midwife a choreographer of the dancers and 'the dance'. She also describes the real problems of sexual delinquency (which will be discussed later). Looking out from her bedroom Isabella witnessed a performance carefully choreographed to suit the marines' fantasy. In the beginning, she did not understand it but she eventually saw the romantic plot through the outpouring of emotions that were hard to control and even now in the $21^{\text {st }}$ century she unpacks these memories and continues to learn and empathise with the women she shared her wartime experiences with.

The allure of the nightlife at the dances at Tuasivi Cape was a far cry from the humdrum of ordinary life in the convent. However, even Alice recalled how the presence of the marines gave those attending the convent a new interest that broke from the strict routines in their lives.

Every Friday, after mass, I'm allowed to go home, and before 5 in the evening, I'm back in the convent. That was my life. But I enjoyed my life. And even the Americans it was nice to see something different. To see different men walking like that, walking the street and they always seem very happy, when you look at them they do not seem to be abusive, they always wave, and smile at you. And they all got girlfriends you know! $!^{23}$

The reference to good-looking marines who 'do not seem to be abusive' is undeniably the innocent view of a young woman who lived a sheltered life, oblivious of the coded messages in their demeanour. This also suggest an awareness, even if only retrospective,

22 Ryan, interview.

${ }^{23}$ McElhiney, interview. 
of the potential for abuse. Many of the marines were teenagers like Alice. They were young, naive and did not have the life experiences that would allow them a deeper cultural understanding. Hollywood was their main educator, and this can be seen in their first impressions of Samoan young women. In his memoirs, a former marine, John J. Carey, described the view of Pago Pago as they entered the mouth of the harbour:

The place didn't seem to have many people or traffic and we could only see a few jeeps in the entire area. Nothing seemed dirty, and there was no litter or junk. Everyone was quiet and seemed to enjoy the paradise before our eyes. If there was music I would have thought I was watching a Dorothy Lamour movie, I never saw anything like it before and don't expect to see anything to match it again. ${ }^{24}$

Carey's pensive description of Pago Pago in 1942 reveals a young man on an adventure rather than a soldier scouting the area for potential danger. Like many young marines, Carey was looking for the familiar symbols like Dorothy Lamour and Frances Farmer who was the 'dose of poison' in the young American's idealistic musings.

Many of us remembered a movie just before the war called 'South of Pago Pago' with beautiful girls all running around in grass skirts. Wow, how lucky could we be, as we strained our eyes looking for a grass skirt. Someone suggested we look for a hardware store that sold lawnmowers. ${ }^{25}$

What Carey and other marines were looking for was an idealised view of the South Seas, described by Brawley and Dixon as a 'sensuous arcadia where, unrestrained by western social mores, islanders engaged freely in sexual relations within and outside the bounds of marriage. ${ }^{26}$ These views had been cultivated through the pens of Robert Louis Stevenson and Somerset Maugham. Others responsible for the same stereotypes include Herman Melville's 'sensational romance of naked maidens' and the artwork of Paul Gauguin. ${ }^{27}$ These lenses through which, foreigners saw island women were reinforced by the Hollywood films. Then came the revelation when seeing them in real life, from a close distance, reaffirmed the fantasies.

\footnotetext{
${ }^{24}$ Carey, A Marine from Boston, 78.

25 Carey, A Marine from Boston, 78.

${ }^{26}$ Sean Brawley and Chris Dixon, "Searching for Dorothy Lamour: War and Sex in the South Pacific, 1941-45." Australian Journal of American Studies 18, no. 1 (2012), 5.

${ }_{27}$ Peter J Kitson, "Sustaining the Romantic and Racial Self: Eating People in the 'South Seas"', in Culture of Taste/ Theories of Appetite: Eating Romanticism by T. Morton (New York: Palgrave MacMillan, 2004), 77 91; Michael Sturma, South Sea Maidens: Western Fantasy and Sexual Politics in the South Pacific. (Westport: Greenwood Press, 2002), 140.
} 
We heard cheering and everyone ran to the port side and frankly we were lucky the sudden weight shift, didn't capsize the ship. What the guy yelled was, 'Holy shit, look over there! Tits! Beautiful bare tits!' On the dock were a couple of young Samoan girls with bare feet, long black hair with a pretty flower over one ear, and they were waving to us. They wore a short wraparound skirt, that we quickly learned was a lava-lava, and it covered them from the waist, half way to the knee. This was their entire wardrobe. They were something to behold. ${ }^{28}$

The culmination of such a view was a sexual end. The fact that the US Forces were given the liberty to use all the Samoan resources, including its people, meant different things to many different people. Alice's view about the marine's smile can mean two things; it might have been genuine or it might have had a sexual connotation.

In 1942 the Photography Regulations were published in Western Samoa as an amendment to the censorship regulations. The new law stipulated that all privately owned cameras be handed in. ${ }^{29}$ These regulations disrupted the livelihood of commercial photographers but most villagers did not own any cameras. The irony of this rule is that while the Samoans were regulated, the US marines had cameras to take photographs of Samoans they were interested in. Most of the private photos taken by soldiers were usually of young women as in the picture below.

${ }^{28}$ Carey, A Marine from Boston, 78.

29 The Western Samoa Gazette, Volume 1-5, 1939-1945, 863. 


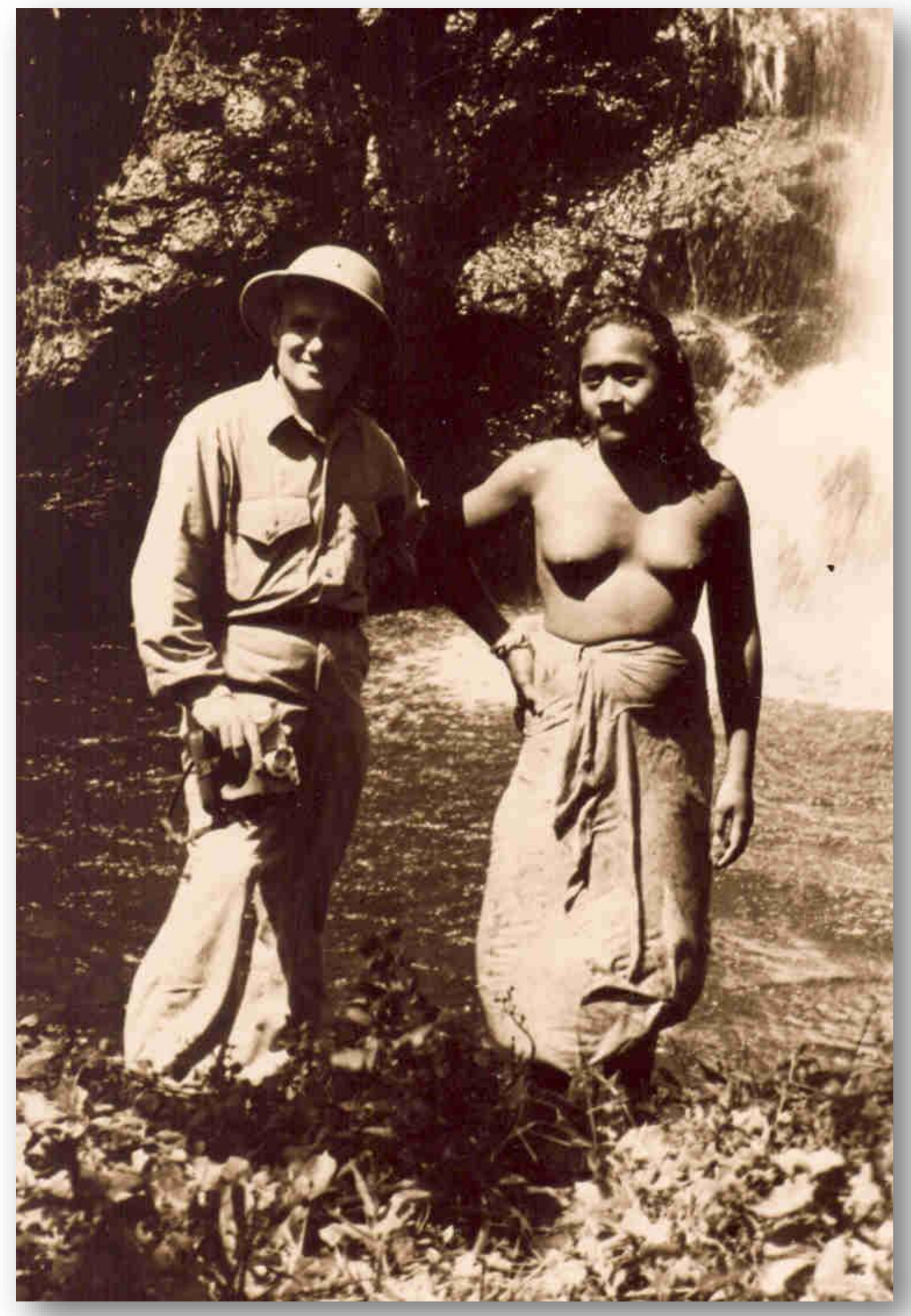

Figure 15 An American Serviceman and a young Samoan girl somewhere in Western Samoa. Taking photographs with topless young women was one of the marine's fascinations. (Source: National Archives, MESC, Malifa.) 
Nanati, Asuega and all the other women in this study confirmed that young women could still go about with their breasts uncovered. It was only during the war that this normality changed. Roland Marbaugh, a former marine of the $3^{\text {rd }}$ Marines stationed in American Samoa, described in his diaries an incident that occurred shortly after the arrival of the main body of the marines in 1942:

The next crisis to arise was the fact that some of the women wore a lava lava around their waist but nothing above. General Larson was bound to cover those pretty mounds with cloth.... The decision was, after three days, that if the Navy issued two green tee shirts to each woman, the chiefs would see that they were worn. The morning after the issue, they all appeared, wearing the tee shirts. But they all had cut two holes in front and every breast was bare! Later on they took to wearing their lavalava clear up to the armpits. The rank and file did not favour this. ${ }^{30}$

Local village narratives have it that it was the marines' carnal fascination with women's bodies that caused women to cover up. Asuega describes a scene she remembered in her childhood that recalled the marines' attraction to the women. She describes a daily scene in Pago Pago that she saw as a 12-year-old.

The marines were there by the road next to the little stream there [pointing on towards the bridge], the marines would pass by the bridge to go eat. There was a track that meanders out to the back where the spring was, that's where women always go to bathe and did their washing. The marines always like to go past that way get to the Mess Hall up where the road is to Fagasa now. I remember when I was young, I saw the marines were always happy when they come by the stream, because the women were there bathing, ia ae e kilokilo aku uma i ai maligi i susu o kaukau mai - the marines, they see all their breasts hang down. My older sisters also used to bath at that same stream. ${ }^{31}$

Bathing in a stream or a freshwater pool was a normal scene in Samoa but it was totally new to some of the marines who misinterpreted this public display of the naked body. The activity drew the marines closer to where the women congregated. Marbaugh's memory of his time in Samoa confirms the obsession that developed with Samoan women's nakedness. He describes a scene very like the one recalled by Asuega, but from a marine's point-of-view.

A pipe was run to each village, and out in the village square the pipe was elevated and curved into a shower and laundry. At about five p.m. every

${ }^{30}$ Roland Marbaugh, 'Full Memoirs', in A Journey with the Marines (www.witnesstowar.org), 159.

${ }^{31}$ Lauvai, interview. 
day, the women and girls gathered at the showers to bathe after their daily chores. The marines gathered too. This was fine, except there were complaints that the boys were laughing and making snide remarks. The feast was called (this meant that the officers had a meeting with the village chiefs). Immediately afterwards a general order was posted stating that it was permissible to watch the bathing in silence and with a straight face. Our C.O. told us, 'okay, you can watch the butt-scrubbing, but I'll bust the first man to crack a smile. ${ }^{32}$

The sanctioned and conditional 'watching' of the women bathing is an example of how social rules were relaxed during the war. In normal circumstances, this behaviour would get the soldiers in trouble with the law.

\section{Sex and Candy}

Wartime popular cultural items, as discussed in chapter 5, were loaded with many meanings. The candies' primary function was as an energy booster for the body and children who were were addicted to their sweet taste followed the marines all the time for more. In Manu'a, the combination of marines, candies and females raised many eyebrows. The chiefs sought to pre-empt the marines from taking advantage of local woman. As Saunia attested, Tufele Faatoia, the Manu'a District Governor since 1924, discouraged any social relations between the palagi marines and the women of Manu'a. All the informants from Manu'a claimed that Tufele wanted only Samoan marines in Manu'a. ${ }^{33}$ Unfortunately, this did not happen. According to Tufele and the village mayor, these lollies 'na pigi ai nai teine Fitiuta, ruined the young women of Fitiuta by the marines... some maligi sent boxes of candies but Tofele found out about it, and they never reached the women. ${ }^{34}$

There were no older informants in Manu'a to give an older age group's view about the relationship between the candies and sexual relations. However, songs reveal how people thought about such wartime relationships. Saunia remembered during the interview a song composed and often sung by young children who absorbed the wartime activities they saw:

A sau se maligi nofo mai i fafo Faagau mai le ua, faamata salamo.
A maligi comes, sits outside.

Head bowed, in a humble look.

32 Ron Marbargh, A Journey with the Marines, 160.

${ }^{33} \mathrm{~Pa}$ 'au, interview.

$34 \mathrm{~Pa}^{\prime} \mathrm{au}$, interview. 
Viga loa le teine, fia tietie taavale i le po loa le maligi aumai le afifi lole fai mai 'Ko!'
The girl then desires to ride a car in the night. Sau The marine brings a bag of candies, and says '[lets] Go!'35

The lyrics of children's songs would change every time they were used but the meaning and the history they tell remains the same. In this song, it seems that the GI gave candies to the kids to keep them happy while he took off with the young lady. The last word, 'Go', can easy be transliterated as 'ko' which means 'pregnant'. The candies as suggested by Saunia were what lured some young women to go with the marines. The candies in this context were laden with different meanings than those given to them by children such as Amanda and Isabella. Amanda's memory as indicated below reveals how some marines used food to win over women.

I can never forget a guy named [Eddie] Griffith, from Indiana. I often wonder if he had died. Every time I hear Indiana on TV, I would remember him. He was called 'Red' because of his red hair. He often comes to see Pulotu, also known as 'Red' because of her thick reddish brown hair. O Red na fia alofa lava ia Pulotu - Red wanted to love/court Pulotu. He brought a salami. Oka se salami! [Signalling the length of the Salami to the middle of the arm.] He hid it under a poncho he was wearing. We couldn't believe our luck. And it was a Sunday; we had just finished eating palusami and taro. $\mathrm{He}$ said to us, 'that is salami'. It seemed he stole it from somewhere or perhaps he is a cook or something. So we cut it up that afternoon and began to slice, slice, slice, e pei lava o le isi toonai le la ua toe ai ai i lena afiafi - Like we were having another Sunday lunch again in the evening. ${ }^{36}$

'Red' from Indiana perhaps hoped that the path to a woman's heart was through her belly. But he did not anticipate the attachment of Pulotu's younger sisters Amanda and Flo. Amanda related that they all became friends, but not in the way 'Red' would have liked. This story has many different versions, not only in Samoa but across the Pacific and in the other theatres of war. Many emotions, hopes and expectations became attached to these food items, heightening Samoan women's engagement with the American servicemen.

\section{'Good time girls' who don't get pregnant}

The participants agree that during the war, there was a rise in what they referred to as 'good time girls'. The common Samoan expression that they gave these women was

\footnotetext{
35 Pa'au, interview.

${ }^{36}$ Iuli, interview.
} 
'teine toso lau'. Asuega called them, 'toso lalau', Faanunumi called them, 'o keige ua solomili i maligi - the ladies seduced by the marines'. Amanda thought they were the most beautifully clothed women in town.

This is the story of the teine toso lau downtown. These women wore beautiful clothes. O le mananaia ia o ofu o teine ia. They dated the Officers and went to their lodgings. Yes, there were houses for the Officers and houses for the lower ranks as well. Some of the girls who showed up wore very beautiful clothes and they went out and toso lau and never returned home. Some of them stayed with other Samoan families who lived closer to where the officers and the marines camped. ${ }^{37}$

Some of the Samoan "good time" girls, were relatives of the interviewees. These young Samoan women and the marines were learning to be adults in a tumultuous time. Asuega remembers how some of her older siblings and their friends became "good time" girls, something she claims the older people of the village did not like. But Asuega asserts that there were many women in Pago Pago who had sexual relationships with the American GIs. Some had babies, but others were very lucky because they did not become pregnant.

I had a sister named Lavasa, she had friends named Teuila (Ginger), and Siava. All from our village, Pago Pago. They always go with some of the marines and eva! But they never had any babies from the marines. I think they had sex with the marines but they did not become pregnant. I think the marines just used them but they never had the babies, yet they were always hanging out with the marines. O le toso lalau ia! And my sister Lavasa and her friends were all nurses. What was good here is that they went and toso lau and there were no babies.

I used to hear they would go with the marines and I saw they had a lot of money. There was a joke I heard those three use to say to each that 'he and he and he and he and she!' then followed by a big laugh. I always knew they were up to something those ones. I don't know where they went with the maligi and do those things. But I know they enjoyed themselves. ${ }^{38}$

As a person who lived through the war as a young woman, Asuega acknowledges the existence of young women whose sexual behaviour challenged the expectations of society. Although she uses critical labeling words such as 'toso lau', which equates to having sexual intercourse with men they do not know a lot about, Asuega did not see it as problem, especially when they did not get pregnant. However, Asuega's change in

\footnotetext{
37 Iuli, interview.

${ }^{38}$ Lauvai, interview.
} 
attitude when she remembered the Pago Pago women who had children fathered by the marines, reflects the malleability of judgement when it comes to moral codes.

Pago Pago had babies. The marine babies were born around 1942, '43. There were so many of them here. E number one Pago Pago i le toso lalau, but I do not want to talk about that. I use to call them, 'E! koso lalau!' They are all grown now, married and are outside of the country. Some of these ladies were a lot older with families. And they still had babies from the marines. Their husbands thought they were pregnant from them and only found out at the birth it's a maligi. E ka ke ma e faamakala ia aikae! - I am embarrassed to tell about these shit eaters! ${ }^{39}$

Asuega did not mince words to describe her disappointment with the women who consorted with the US servicemen while they were still married. Her reactions suggest that adultery rather than illicit relations was the problem. Single women, if they did not become pregnant, escaped societal punishment. But when a married woman consorted with a marine and then became pregnant, things became a thousand times worse for her. I described a similar incident that occurred in the district of Faleata in Western Samoa. ${ }^{40}$ The social punishment for these "good time" girls' misbehaviour depended on whether they became pregnant or not.

The changing wartime social situation then begs the question, to what extent did Samoan women protect themselves from unwanted pregnancies? What measures did the colonial and cultural authorities offer to prevent unwanted pregnancies? The US soldiers were issued condoms as a way of preventing Venereal Disease (VD), which was the generic term for Sexually Transmitted Disease (STD) that could cripple a whole unit for weeks. The soldiers were well informed about the effects of VD with Sex Hygiene and VD pamphlets that were issued at every US marines' camp by the US War Department. The pamphlets explained about sex relations, and how to steady their sexual impulses while at war. The risk here is that the bacteria or virus that causes VD is carried by the woman. More importantly, the marines had access to prophylactic kits to

\footnotetext{
${ }^{39}$ Lauvai, interview.

40 Mataia-Milo, "There Are No Commoners in Samoa", 62-4
} 
treat themselves if there was any suspicion of infection. ${ }^{41}$ There do not seem to have been any educational or medical measures directed at Samoan women themselves.

Wartime sexual encounters between Samoan women and American servicemen challenged the social boundaries and how they were lived out daily. Illegitimacy had been introduced to the Samoan way of thinking by the missionaries and Europeans together with other binaries such as good versus evil, darkness versus light, marriage versus fa'apouliuli (living in darkness i.e., de facto/unmarried). Illegitimacy is only problematic when seen from a western perspective. The western perception, as outlined by Andree Levesque, is that 'reproduction was only respectable within the bounds of marriage. ${ }^{42}$ This contradicts Samoan cultural norms where both the lineages of both parents were acknowledged. Even during the war there were Samoan women who remained unmarried but who had children from several Samoan men. Often, these Samoan women were labled as 'le au salea', which is a euphemism for a courtesan, to put it in a polite manner. ${ }^{43}$

Not all wartime sexual encounters were consensual. Some women still live with the trauma of rape by some American marines and the baby that came afterwards is a constant reminder of what happened to them in their youth. Rape is not uncommon in Samoa. Isabella revealed that some of the inmates in prison at Tuasivi were mainly moetolo and toso teine. ${ }^{44}$ Coerced sexual encounters also happened in Samoa during the war. Liua'ana reported a church minister who was dismissed because he was involved in providing such services during the war. ${ }^{45}$ The vast differences between Samoan women's sexual values and those of the marines, prompted many to exploit Samoan women, knowing it would be easy to escape such crimes.

${ }^{41}$ US War Department, “Sex, Hygiene and Venereal Disease” Pamphlet, September 30, 1942, (Washington, US War Department), http://www.thefewgoodmen.com/thefgmforum/threads/venerealdisease-prevention-in-ww2.15250/ accessed, 1 December 2016.

42 Andree Levesque, "Prescribers and Rebels: Attitudes to European Women's Sexuality in New Zealand, 1860 - 1916," in Women in History: Essays on European Women in New Zealand, ed. Charlotte Macdonald, Barbara Brookes and Margaret Tennant (Wellington: Allen \& Unwin, 1986), 4.

${ }^{43}$ Salea - a type of pandanus leaf often discarded by weavers because of its coarse texture, dull colour and that is easily punctured. Women would only use these to weave mats for underlays. It is important to note that such labels are seldom expressed in public.

${ }^{44}$ Louise Mataia-Milo, "Interview with Isabella Stehlin Ryan," (New Lynn, Auckland 7 May 2015).

Moetolo - normally translates as a sleep crawler/ night crawler. Toso teine - rape of a woman.

${ }^{45}$ Liua'ana, Samoa Tula'i. 
The war came, I was there. I had a girl friend from Tutuila. She said to me, 'Tautau lets go and get some washing' (Faamolemole o le upu o le a alu atu - Please the word is going to come out.) Ua ma o, ua tu'u le tagamea, ae fai le isi tagamea - We went, we did not do that washing but another washing was done [touching her crouch]. This was done [Tautau kept touching her crotch], it was a different kind of washing. The man held me. I saw my friend was not upset by this. She was the reason why we went. The palagi came [please the word] he came to me [touching her crotch to signal the act of sex] - that is how I got my daughter here [tapping her daughter/interview assistant on the arm]. This is the evidence. My girlfriend left [for Tutuila], she had a child and I stayed here with my [daughter] [tapping her daughter's arm, who was now crying]. O lea! - This one! Her father is a palagi [making a sound to resemble a name she was trying to remember? sioooosi?] I forgot the name of the palagi. ?Temtres? I think. ${ }^{46}$

Tautau was a 22-year-old widow with three young children in 1942. At 97, Tautau's only memory of the war was the trauma she went through with her friend. Washing clothes for GIs was an easy way to make money during the war, but in this case this trusted exchange veiled something more threatening.

The palagi came, held me, trying to get me to agree, I tried to push away but he forced me. Ua faamalosi loa au e le palagi, e leai se mea ou te mafaia, ou te au vaivai. - The palagi raped me and I could not do anything, I was too weak. [Tautau cried and was upset, then became silent for a few minutes, daughter crying. - Interview called off.] ${ }^{47}$

Old age robbed Tautau's memory of the name of the American GI who forced himself upon her. Yet she did not forget the event itself and the evidence of her experience. According to Tautau, the palagi was a 'fitafita o le ami - soldier of the army'. Tautau's story illustrate the increased risk of sexual violence for young women who lived alongside the marines.

Tautau regretted agreeing to accompany her friend and the ordeal that resulted. Whether Tautau's friend was also forced we will never know. What we know of Tautau's traumatic ordeal is that after so many years she was still affected by it. It is her earliest wartime memory. What is heart breaking is that she recalled coming home and being judged for consorting with a Marine instead of being seen as a victim of a sexual assault. Laurel Thatcher Ulrich's frustration with the famous slogan 'well behaved women seldom make history', the suggestion that only good or pious women deserve to

46 Tautautasileniualeotaleuluaiali'i Leota, interview by Louise Mataia -Milo, 29 August 2014.

47 T. Leota, interview. 
be characters of history, also rings true for Samoan women. ${ }^{48}$ They have been represented as passive participants and little attention has been paid to their wartime lives, especially their sexual encounters.

The rape of women by American marines has not entered the record of Samoan women's history. But Tautau and her story, as described above, raises many questions about the dynamics around wartime sex. Most of this generation have passed away, taking with them their secrets about sex with the marines, whether these relations were transactional, consensual or coercive. But how did the women deal with the trauma of sexual violence? Did they share it with their familes and friends? Did they report it to the local authorities or to the military Police (MPs)? Did they entertain the possibility of abortion as an expression of their rejection of what happened to them? And what was the view of the US command about such crimes? Were they treated the same as in other theatres of the war?

Precisely how many Samoan women were raped during the US Forces' occupation of the Samoa Islands will remain unknown because the majority of that generation of women is now gone and there is no official record of any reported incidents of rape involving US marines. To date, no statistics or any reports about sexual violence against Samoan women have been found. It seems that these records were destroyed after the war. Military historians also have been silent about reawakening such experiences and have perhaps banked on the understanding that it is something best forgotten.

We do know though that rape was reported by the Military police as at the top of the crimes committed by GIs in Europe. ${ }^{49}$ It is estimated that about 1.4-1.9 million women in Germany were raped by soldiers of the Red Army during World War II.

Messerschmidt in her 2006 work outlined that many German women committed suicide as a result and that rape alone led to the conception of 200,000 children. ${ }^{50}$ How many of the approximately 800 to 1,200 Samoan children fathered by US marines were a result coerced sexual encounters will remain unknown. From Tautau's narratives it seems that

48 Laurel Thatcher Ulrich, Well-Behaved Women Seldom Make History (New York: Alfred A. Knopf, 2007).

${ }^{49}$ Mary Louise Roberts, What Soldiers Do: Sex and the American GI in World War II France (Chicago: University of Chicago Press, 2013), 195.

${ }^{50}$ James W. Messerschmidt, "The Forgotten Victims of World War II," Violence Against Women 12, no. 7 (2006), 706-12. 
many were not reported. Roberts in her study of the US soldiers in France condemns the Americans' arrogance and sheer power displayed in the attitudes of the American soldiers towards women and sex that led to French anti-Americanism in the post war era. ${ }^{51}$

The different sexual encounters highlighted in the Samoan women's naratives in this thesis show a wide range of sexual encounters, as "good time" girls, as observers and as victims. This new history invalidates the remembrance of Samoan women's wartime experiences as just, 'o keige Samoa ma lakou kamai maligi'. At the same time, the high rate of births from such a small population calls into question the level of women's understanding of carnal/bodily knowledge, and their understanding of sex which are fundamental to the experience. These questions reveal more about the society than the individual.

It is to these equally sensitive questions that I now turn. What did the women interviewed have to say about how they understood sex and bodily knowledge and the cultural influences on this knowledge? Did their wartime behaviour, including the decision to participate in sexual activity, reflect personal agency?

\section{Bodily knowledge}

Bodily knowledge in this research refers to women's understanding of sexual health including sexual anatomy. Women's bodies and their sexuality have been a highly contested space throughout history. In Samoa, the level of women's understanding of their bodies is indicative of the complex jumble of traditions deep-rooted in customs with a strong Christian influence that contested the control of women's bodies. Katrak's study of indigenous women's sexuality claims that 'traditions that govern the woman's body, are more important than the woman. ${ }^{52}$ For a Samoan woman, Christian morals, and the Samoan concept of the va tapui'a were the entwined traditions that shaped a woman's lack of knowledge about her body. The social separation of a woman's biology

51 Roberts, What Soldiers Do, 7-11, 230.

${ }^{5}$ Ketu H. Katrak, "Politics of the Female Body: Postcolonial Women Writers of the Third World", (New Brunswick, N.J.: Rutgers University Press, 2006), 156-58. 
alienates the individual from using their sexual agency. Moreover, when they exercise personal sexual agency outside of the norms of tradition, they pay a severe price for it.

Bodily knowledge is always euphemised and surrounded in secrecy. The Samoan concept of the va tapui'a - sacred relationship, for example, has a bearing on the way bodily knowledge is transmitted. ${ }^{53}$ Samoan codes of social behaviour prescribe that a woman/a sister is the feagaiga or covenant of her brother. This is why bodily knowledge for women is transferred through gender-specific socialisation at the aualuma. ${ }^{54}$

The young learn by observing and participating in cultural activities. At puberty a young woman learns the importance of virtue and her participation in the hosting of aumoega - marriage courting parties. A young woman's role in this activity is very minimal, however. Tiresa stressed that young members of the aualuma and the children that frequented the aualuma house were sent home when the aualuma hosted a aumoega and a faletautu. 'O aumoega e matuai faasa ai lava teine laiti ma tamaiti. - Young ladies and children were not allowed at the aumoega ${ }^{55}$ According to Tiresa and Faasalafa, young women attended the hosting of such parties only with the consent of the elderly women. Moreover, the older women's role in these traditional gatherings was to ensure that traditions and protocols were observed.

Tiresa was already part of the Vatia aualuma in 1941 who hosted an aumoega from the village of Solosolo just after the beginning of the war. Many aualuma groups did not meet during the war so there was a break down in the networks of advice for young women. Amanda stated in her interview that towards the end of the war only some groups of women who lived within the same area would get together, like the 'proxy' aualuma set up by Pulotu and her friends to host 'Moso'oi Pala'. ${ }^{56}$

\footnotetext{
53 Va-tapui'a - the close relationship between a sister and a brother. Also referred to as a 'sacred/ taboo relationship between a sister and brother. The worst offense in pre-Christian society was incest between a brother and sister. Elders believe that once the va is broken in this manner, humans have become no less then animals. Despite the strong cultural laws that regulated behavior, incest continued to happen. 54 Anne Marie Tupuola, "Learning Sexuality: Young Samoan Women," in Bitter Sweet: Indigenous Women in the Pacific, ed. Phyllis Herda, Tamasailau M. Suaalii and Alison Jones (Dunedin: Otago University Press, 2000), 61-71. Tupuola found a similar hesitance of Samoan young women to talk about their sexuality in her own research based in New Zealand.

${ }^{55}$ Fiti-Brown, interview.

56 Iuli, interview.
} 
Christian views of pre-marital sex as unclean and 'sinful' contradicted Samoan beliefs and resulted in the censorship of bodily and sexual knowledge by the 1930s. Koke Aiono highlights her reliance on her father's sisters, who were familiar in the cultural protocols of marriage relations from the aualuma, rather than her mother who grew up in a pastor's house and knew little about the customs of the taupou. ${ }^{57}$ These competing ideas to influence women's bodies echoes Mathur's claim that women's bodies are contested sites. ${ }^{58}$ The young women were conditioned to view sex as something unclean and 'sinful'. The women were not prepared for sexual encounters because the channels of information were blocked. The lack of understanding of bodily knowledge placed them in a vulnerable position in the presence of thousands of marines who saw Samoa as an arcadia of sexual fantasies.

Participants' responses to questions about what kinds of conversations they had with their mothers about sex and bodily knowledge ranged from short expressions of 'lipi ola - absolutely nothing' to 'autometi a le iloa - automatic knowledge' to being silent. Another common response to these questions comes from their body language, and their gestures, the way they shifted their bodies and faces. During the interviews, most of the participants shifted eye contact from the interviewer to looking outside, focusing on some invisible object that was hard to see. Their posture changed and the mood shifted from excitement to quietness, signalling some reluctance to talk. When the more sensitive issues were raised, such as wartime abortion, maternal health, and sex with the marines, some of the participants suddenly altered their intonation to a quiet whisper in case someone else might hear. The changes in gesture and body language indicate a physical security mechanism for safeguarding memories about a private subject.

The mother-daughter relationship is also central for communicating vital information. However, Isabella claims that the conflict between the Samoan cultural and Christian views heavily influenced her mother's life and in turn affected her understanding of her body. In fact, Isabella found her lack of bodily knowledge, especially about reproduction, frustrating and she now protests the factors that affected her own mother's ability to talk about such women's issues and bodily knowledge: 'My mother

\footnotetext{
${ }^{57}$ Enari, "Fuatino Koke Aiono," 72.

${ }^{58}$ Kanchan Mathur, "Body as Space, Body as Site: Bodily Integrity and Women's Empowerment in India," Economic and Political Weekly 43, no. 17 (April 26 - May 2, 2008), 53-54.
} 
was a faifeau's - pastor's daughter and she is very much into girls being protected, I think more sexually. You can't go anywhere without her wanting to know - something that was hard for the young to understand because you never know why! I thought she was over protective, too fiapule - want to be the boss, too strict. That was my thinking. ${ }^{59}$ Isabella in her senior years apprehends that her mother's life was very much influenced by the conflict between cultural and religious outlook about women and how she had to be the manifestation of what a Christian woman is supposed to be. 'Mama was not a girl from town, [she was] a faifeau's-pastor's daughter! E polesi le amio e fa'a'aoao uma i ai teine o le aulotu - She had polished manners that all the girls from the congregation try to emulate. ${ }^{60}$

Isabella was in her pre-teen years during the war and her body was beginning to change, something that she was anxious about. Her mother's silence did not help and she was also not a member of the aualuma. Isabella suffered on her own.

You know even the [monthly] period, never talked to us about it. You learned from other girls in school, and from her, [shaking her head] not a word! My first experience was going to school and I had my period and I cried, because I didn't know why. But one of the girls said to me, 'eh, that is what happens to all the girls.' Then I came home because I had to turn the skirt on the side and I told my mother and then she told me, you know. E leai se mea, there was nothing to prepare you for anything. As if the period was a sin or something dirty or wrong. She just showed me how to use the rags to pin on your panties. And she said to me, 'o mea ga e tutupu a i masina uma - it's going to happen every month. Just like that! That was mama! I wish I knew a bit more long before, even to prepare me about my emotions, and the pains. So when I had my children I thought I was not going to repeat that ${ }^{61}$

The disinclination to pass on bodily and sexual health knowledge to young women restricted the flow of knowledge to the next generation. This perception politicises the position of everyone who has an interest in the realm of Samoan women's sexuality. The whole subject becomes a contest about power relations, and about who has the right to control bodily knowledge. It further implies that to make a woman aware of her body would empower her, so it is best to keep the young woman in the dark. The idea that knowledge would help the individual make informed decisions and proactively

\footnotetext{
${ }^{59}$ Ryan, interview.

${ }^{60}$ Ryan, interview.

${ }^{61}$ Ryan, interview.
} 
prepare her for motherhood is ignored. On the other hand there is also the view that she would use the knowledge to promote individual desires that may bring disrepute to her family.

The contest over Samoan women's bodily knowledge is a contest of perceptions between Samoan cultural institutions and Hebraic or Victorian views on Samoan women. Then there is the Samoan view (which encompasses both camps) versus the anthropologists of the late 1920s who placed on the world stage a view of Samoan adolescent women and their sexual mores as being promiscuous. This subtle repressive mechanism produced a generation of women with very vague knowledge about a crucial component of what makes a woman's experience. Young women such as Alice in their adolescent years found that the silences about bodily knowledge were mystifying.

When we talk about it, we were so ignorant! We asked questions like, 'what did they do, you know they go in there and have a [pause], and they don't use the word 'sex'. Because we don't know that, we used to say, 'do they do those things? You know. That men and women do... you know! We were so innocent we don't know what's really going on, even though in your mind that's what they are doing but you don't ask the question. ${ }^{62}$

The wartime circumstances challenged such cultural coding and opened new experiences to young Samoan women who considered their own understanding of sex and bodily knowledge then as 'ignorant' and 'innocent'. Alice was older than Isabella and was beginning to enquire about boys' and girls' relationships in the 1940s. Her source of knowledge was through the day pupils at her school who brought stories about their social lives outside of the convent which she thought were a lot more interesting than the tedious life of the convent. Alice remembered that even secret conversations were censored by self-proclaimed unofficial agents of sexual knowledge.

We have secrets - talking about boys [asking] 'I wonder what it was like to go out with boys'. We were very [pause] we just don't know nothing about it! So we talked about it and silly questions we asked another girl, like, 'Did you know when they go to bed, what do they do?' You know it's very, very innocent about those things because you don't listen to people doing that? We were all in this same sort of thing and we lived that sort of life or you mix with the girls at school [the day students], they were the ones who bring stories and talked about the same things, the Americans, maybe they lied you know saying, 'oh I have a boyfriend, he is an American, he is good

${ }^{62}$ McElhiney, interview. 
looking, and he promised that he will come back and take me to America' that sort of thing they talked about - and you know, being isolated like that you always like to listen to their stories and what they say.... We just dream! Only dream about things like that, about what you're going to do, and what sort of man you are going to marry and things like that! And if it goes further [someone will say] 'Stop that! You are not supposed to talk about things like that.' Somebody would hop in. Somebody older than you saying, 'Hey you are not supposed to talk about those things!' And this is news coming from the outside girls. You want to be friendly with those ones, they bring that news. Sometimes you believe what they say that they have a boyfriend and what's his name? And they can tell you a funny name and you believe it, but then you say, 'does your mother know what you do' and they say, 'oh yes I went out with him last night and I had some chocolate and he gave me this [signal a present in the palm of the hand] and he said that he is coming back and take me home, take me to his family.' All that sort of thing, and every day you want to talk those ones because they got news coming from outside, whether they were telling the truth or lie. ${ }^{63}$

Alice's experiences indicate how gossip, often considered as an idle and malicious form of social control, can fill in the gaps of knowledge. Watkins' and Danzi's discussions on Jewish and Italian women posit that 'gossip permits the testing of normative waters from the safe distance... to observe their friends' reactions'. ${ }^{64}$ This contrasts with Robert Louis Stevenson who characterised gossip as 'a Samoan sickness'. Stevenson's description of Samoan gossip, does not describe Alice's 'circle of consultation' or what Watkins and Danzi refer to as 'gossip networks'. Conversations with the day schoolers channelled knowleged to Alice about was was going on outside of the nun's compound. Alice lived in a convent during the week and together with her friends she identified that the lack of knowledge about sex and the excitement of a social life was a problem. They evaluated the day pupils' liberal social lives and their new behaviour during the war and experienced the normative pressure to conform as they learned what their friends were up to, outside of the convent.

The church influenced Isabella and Alice's level of bodily knowledge. Alice lived and went to school in the convent and was already committed to becoming a nun; she had a very limited understanding of sex and bodily knowledge. Perhaps there was an

\footnotetext{
${ }^{63}$ McElhiney, interview.

${ }^{64}$ Susan Cotts Watkins and Angela D. Danzi, "Women's Gossip and Social Change: Childbirth and Fertility Control among Italian and Jewish Women in the United States, 1920-1940," Gender and Society 9 , no. 4 (August, 1995), 469-71.
} 
assumption that since they intended to live a life of celibacy, there was no need for such knowledge.

The narratives clearly show the girls limited knowledge about their bodies and raise question about who owns the Samoan woman's sex? Is it the individual who makes a conscious decision about what to do with her body? Is it the local culture that has coded the woman's body and the social orientation which the woman challenged during the war when she cohabited with a marine? Or is it the church?

\section{Sex as power}

The Samoan women of the Second World War era inherited a history of sexual agency that was heavily controlled by Samoan cultural and religious codes. Mageo in her discussion of Samoan women's spiritual possessions asserts that the women, 'who are not supposed to be powerful', negotiate this legacy by camouflaging personal agency. ${ }^{65}$ Mageo's notion that 'victimization maybe a camouflage for agency' is important to understanding how Samoan women thought of bodily knowledge and perhaps negotiated their sexual behaviour during the war. ${ }^{66}$ From a feminist point of view, the Samoan social structure succeeded in the exclusion of women's sexual agency from the framework of power by regulating their sexual mores.

Wartime circumstances caused people to act differently from during peacetime. The influx of foreigners caused many types of socialising that were difficult to control. Neither the Samoan culture, nor the church, nor the colonial governments had any jurisdiction over the marines' sexual mores and therefore they were unable to exert much force on their moral behaviour. As can be seen in the high incidence of illegitimate children, sexual relations occurred and they rattled the fundamentals of Samoan social structure, caused moral panic and heightened people's sense of responsibility. The older people and the missionaries condemned the women who had sexual relations with the marines.

Samoan society's criticism and stigmatising of women, either through beatings or name calling was not new. Margaret Mead outlined in 1928 that some women received severe

${ }^{65}$ Mageo, "Spirit Girls and Marines," 76

66 Mageo, "Spirit Girls and Marines," 76 
beatings and had their hair shaved for unrestrained sexual conduct. ${ }^{67}$ Isabella mentioned that some of the girls who had intimate relations with the marines were given a hiding by one of the parents, usually the mother. Jeanette Mageo has asserted that marriage in pre-Christian Samoa was a sexual economy geared towards a political end that uplifts the status of the family chiefs, the village and the district. ${ }^{68}$ Michener discovered this first hand through the father of his Samoan companion who told him: 'white babies good for Samoa ${ }^{99}$

The reputation of Samoan society suddenly was called into question. This enraged many people and led to the stigmatisation of women who had babies with the US marines. Saunia and Saini saw how the chiefs responded in a critical way towards women. The chief of Manu'a used his position to have all the marines removed from the Manu'a group: 'Most of the women who got pregnant from the marines in Tutuila came back and had their children here. There were many women from this village (Fitiuta) who had babies from the maligi. This angered Tufele and he said that all the marines would be removed from the island. None of the women were not allowed to go down to the water to say goodbye to their maligi. ${ }^{70}$

Although the anger may have subsided and the process of social absorption slowly mended the seams between the old and the new experiences, tempers could flare up from time to time. Sarcastic songs were often sung to commemorate these painful yet character defining moments. Saunia remembered during the interview how the village children created songs about the adults' attitude towards the young women who became intimate with the marines.

Se na fai ai foi pese a tamaiti i le'a mea. The children composed a song in remembrance of this episode.

$\begin{array}{ll}\text { Talofa lava, } & \text { Talofa lava } \\ \text { Ua vali ou laugutu, } & \text { You paint your lips, } \\ \text { sele fulufulu mata, ma vali laumata. } & \text { pluck your eyebrows, paint your eyelids. } \\ \text { Pe ana mafai lava ona ou kovana, } & \text { If only I was the governor, } \\ \text { ua ave uma outou e faggoto i tai } i \text { le moana, } & \text { I will sink you all in the deep moana }\end{array}$

\footnotetext{
${ }^{67}$ Mead, Coming of Age in Samoa, 273.

${ }^{68}$ Mageo, "Spirit Girls and Marines," 146-148.

${ }^{69}$ James Michener, The World is My Home, 42.

70 Pa'au, interview.
} 
Tufele matua (Tufele the elder) was angry with his village of Fitiuta and Ta'u, about our village girls. Because there were so many papalagi here at our village. I saw them like that. ${ }^{72}$

Tufele matua's retort typifies a chief's reaction against the young women who defied the status quo and the expectation that women be virtuous and honourable Christians.

Some elders tried to avoid contact with women who socialised with the marines. Others tried to stop the girls from attending the weekly siva. Such reactions reflected their embarrassment and the impact these sexual encounters would have on Samoan society in the long term. However, the old people's reactions, as seen in Tufele's response differed very much from those of young people whose lives were not yet coloured by the social constructs of the time. Isabella described her reaction as a13 year old girl when she discovered a 'war baby'.

There was a family from Fagamalo, Faamoe was the man's name. I know it was not his daughter but a girl from his family had a baby from a marine and I remember going there admiring the pepe paepae manaia lava - a very nice white baby! Pei sa manaia lota alofa ma lota fiafia i le pepe paepae, e paepae a - It seemed I was very fond and loved the baby and was happy with it because the baby was white, so white! Yes that was the experience at that time. We didn't care whether it was out of wedlock or what! All we thought of was that e manaia le pepe pa'epa'e (it was a beautiful white baby). I remember the baby was a girl. I wonder where she is now. There were many other babies like that. There were other American marines who were there when the girls gave birth and they registered the children. ${ }^{73}$

The young Isabella disregarded moral judgement and simply embraced the child whose physical features fascinated her. The young adults such as Isabella already understood circumstances into which the 'pepe paepae', soon to be a common occurence of this era, was born.

The example of women who consorted with American marines while already married presents a different aspect of Samoan women's wartime sexual encounters. People all have different ways of viewing their often-brief wartime relationships with the marines. Sex has always been used for politics, only this time some women opted to focus on

${ }^{71}$ Lapa refers to the coarse hard surface of the corals that were once used to scrape objects like food.

${ }^{72} \mathrm{~Pa}$ 'au, interview.

${ }^{73}$ Ryan, interview. 
their own personal politics. Cynthia Enloe claims this application of personal agency was a form of resistance towards the rules that repressed personal agency. ${ }^{74}$ Enloe's idea resonates with Mageo's notion of camouflaging personal agency. ${ }^{75}$ Women like Asuega, Isabella and Alice, however, were too young to make changes to their lives.

One way of thinking about the challenge in women's sexual conduct is that women understood that foreigners were not burdened with the obligations of connectedness, unlike the Samoan men. Young women chose pre-marital or extramarital relations with Americans over the expectations of chastity or fidelity. The order of mores was reversed. Many would criticise Asuega's truth about the "good time" girls from her village that noticeably stained the reputation of their families, chiefly titles and traditional political influences. Yet her reflections reveal how the war loosened the once tightly riveted social and moral behaviours and how some women did not conform to social expectations.

Amanda and Asuega revealed that some women chose to leave their families to get closer to the marines they had relationships with. They wandered away from the village to socialise with foreigners. Amanda claimed that women would go to places in Pago Pago and Fagatogo to get close to the marines. Alice in Apia confirmed there were a few places that existed in Apia which offered sex.

Yeah, well yes like people that was selling sex and that, yes! I heard that was how it started, from Eki [Aggie] Grey, but I did not know what it was like at the back, and because you were so young, [when] people talk about it, it doesn't enter your mind what they were doing, until much later and then you realise, there was really something going on. During the war, there were a lot of houses like that, that men go in with women and have those sex, whatever you call it. You know! And you would talk about it when you go pass and people say, 'That's where they go! That's where the Americans and the girls meet.' It's funny too because some of the Samoan girls (women) seem to encourage their kids, the girls to go to these places.... This is in town, the area right in town (where her family lives). ${ }^{76}$

\footnotetext{
${ }^{74}$ Cynthia Enloe, "'Gender' Is Not Enough: The Need for a Feminist Consciousness." International Affairs 80, no. 1 (2004): 95-97.

75 Mageo, "Spirit Girls and Marines."

76 McElhiney, interview.
} 
One of the characteristics of the change in sociey's behaviour is that women who had babies were ridiculed more as compared to women who did not have babies. If this is the case, then where do individuals like Tautau, who was assaulted, fit into the picture? It seemes that society was unable to offer any healing for the victim(s) of sexual violence during the war. Perhaps being ridiculed was better than being singled out as having corrupt morals.

Scott posits that language or systems of meanings, is an effective system of signification that categorises people. ${ }^{77}$ Society, in its anger assigned specific derogatory metaphoric expressions and sets of meanings to the women who had sexual relations with a US marine. The metaphor of the 'tosolau' for example has a set of built-in meanings which specifically indicate Samoan society's anger when women exercised their sexual agency during the era. For Amanda and Isabella it was during the war when women started to have white babies that they became aware of people applying the term tosolau to Samoan women. Tosolau is a fishing term for pulling to shore a fishing net made of lau - coconut leaves. The term suggests that women who had sexual encounters with the marines were not keeping to the traditions of marriage, but choosing to cohabit with the marines, whose genealogy, and resources they were unable to access. People relate to each other as historical characters who are constituted through their experience. The event of the war constituted the stigma category of the 'tosolau'. I have listed some of the shaming metaphors for the Samoan children of the marines in the Mothers Darlings. ${ }^{78}$

Samoan women's sexual agency during the war may have been seen by the elder people as a reflection of society's inability to have any political power over women's sexual mores. Stigmatisation was a common response but not all shared such views. Isabella as a young girl adored a marine baby born close to her home, 'A girl had a pepe paepae magaia - a beautiful white baby. It had blue eyes. We [the kids] did not care if it was out of wedlock or not. All we liked was that it was a nice white baby. ${ }^{79}$ Many of these relationships only began to surface when the US troops rolled out in 1944. Marbaugh

\footnotetext{
77 Scott, "Gender: A Useful Category of Historical Analysis," 1062.

78 Mataia-Milo, "There Are No Commoners in Samoa," 66-67.

${ }^{79}$ Ryan, interview.
} 
writes of his discovery of these romances as the $3^{\text {rd }}$ Marines made their way back to Pago Pago from the villages in 1944:

It was quite a sight, with the men all swinging along and their girlfriends crying and clinging to them all the way. Many romances came to light that hadn't been known about before. One of my buddies had married a beautiful Samoan girl under Samoan law, which was illegal at the time. Now she was pregnant, I heard him tell her he would return for her. She replied, 'You pepello [sic] (liar). You leave, I have little marine, and I never see you again.'

Fa'anunumi remembered a song that people sang after the war which depicts the effects of wartime sexual relations:

Le tausaga e 42, na tu'i ai au e fagafanua,

le vaatofu a sapani se manu a ou leaga ai

fua. Le niga lenei o maligi ma le latou faifai

isi. ta lau mai ai nei mea mata pu laiti.
In the year 42 ,

I was fired at by a Japanese submarine and

it almost got me. The maligi, with their casual manner, manner brought about these [people] with squinty eyes.

Tele lena o le valea, o nai tamaitai laiti. Tau faitagitui i le nafu ma faasiisii tamai maligi. faatofa atu $i$ ai, ae tali mai na le mafa. Aue, talofa e, pe o ni fanau ea a ai. ${ }^{81}$
The foolish young women at the wharf, in

lament, held up the small marines to

farewell. But without a response, they all end up in despair.

Although the war ended well for the Allied forces, it did not end well for the many Samoan women who had had children with the American marines. Only a handful of relationships resulted in marriages at the end of the war. Many women carried the stigma with them all their lives. The "goodtime girls" who did not get pregnant escaped this societal wrath. Those who were raped took a vow of silence about their experiences. Many of the children and now their grandchildren from these sexual relations have tried to connect to their American side but mainly without success. ${ }^{82}$

${ }^{80}$ Marbaugh, A Journey with the Marines, 209.

81 Tupai-Taeao, interview.

82 Bennett and Wanhalla, ed. Mothers' Darlings of the South Pacific, 1,77-8. 
This chapter has explored Samoan women's wartime sexual encounters and revealed the many forces at play. The women's narratives make sexual encounters more visible and show the diversity of sexual experiences and understandings at the time. Not all women who had sexual relations with American servicemen consented to such intimacy. Some women encountered sexual violence. The lives of women who were sexually assaulted by the marines need to be addressed. Understanding the fine complexities of Samoan women's wartime sexual encounters shows the awkward nature of the multiple wartime agencies that were in contest with one another. The contest between the individual and the society over sexual mores and personal agency is indeed a power struggle over who has influence over these social mores. Samoan's women engagement with wartime popular culture also influenced sexual relationships. The Samoans who acquired a taste for candies, like the young women, became vulnerable when some of the marines exchanged them for sexual favours.

Finally, the wartime social circumstances transformed the way women thought about themselves and how they began to challenge the status quo by exercising their personal agency. During the war Samoan people, their traditions and their understandings of sex intersected with other cultural and foreign ideas about sexual mores. Women's sexual encounters with the marines may have been viewed as a betrayal of the social order or a loss of Christian morals and some certainly suffered the social consequences of pregnancies out of wedlock. But this thesis has revealed a darker side to wartime sexual encounters as well. Women in war zone areas were vulnerable to rape. Tautau's experience highlights that sexual violence did occur in Samoa during the war. Some of the children were products of sexual violence. Knowing these facts about Samoan women's wartime violent encounters then calls into question the correctness of the 'o keige Samoa ma lakou kamai maligi' vision of history. 


\section{Chapter Seven: Conclusion}

This thesis has addressed a topic that has often been treated with sarcasm and silence: the experiences of Samoan women during the Second World War. The questions asked about the wartime lives of these women have led to the discovery of a variety of wartime experiences that were extraordinary for all, exciting for some and painful for others. This thesis is also a response to the misrepresentation and lack of consideration given to Pacific lives during this global phenomenon. Historians preoccupied with politics and economics have overlooked the importance of ordinary people's lives and the historical significance of the normal business of living in the course which social changes were normalised. Samoan women's wartime lives matter and deserve to be a part of Samoan history and the history of World War II.

Seeking answers to questions about a very silent part of our shared history meant requesting the help of the generation of women who experienced the war. Their contribution, through sharing their personal experiences, became the bedrock of our knowledge, connecting the present to the past. Although the women interviewed are by no means representative of the population at the time of the war, their stories are the windows that allow us to enter Samoa's wartime history. The interviews revealed aspects of women's complex lives not known before. The women's subjectivity, their understandings and the meanings they made of their wartime realities illuminate their relationship to their history. Each of their experiences was different. There was no archetypal wartime experience.

The study has examined the extent to which the war impacted on four aspects of Samoan women's lives. It began by locating their lives within the wider history of Samoa on the eve of the war and showing how colonial entanglements had a bearing on the different trajectories that women's lives took. The war was another type of 'lesolosolou’ which the Samoans, especially women, endured. Women's lives before the war were already "governed by many"-by other people, concepts, culture and the churches - though they also retained their own personal agency and were far from passive. As individuals, women articulately negotiated their lives and their roles and 
balanced the competing demands of tradition, colonial temperament, Christianity and the unfolding wartime situation.

The war brought to Samoa a multitude of American servicemen who saw Samoa through a "romantic" lens as an arcadia of unrestrained social mores. In contrast, through this research Samoan women reveal their wartime experiences in their own words. The women's narratives indicate that the war interrupted lives in many ways causing them to rethink their roles in response to the changes.

One of the major findings of this research is that social transformation was a response to the war's disruption of physical and cultural spaces and the critical structures and ideologies that are central to Samoans' way of life. The arrival of the war brought a mixture of reactions. Some were fascinated by the sheer magnitude of the events occurring and the new vistas that broke the monotonous tune of island life. But soon the novelty wore off and the excitement was replaced by anxiety when people began to see how the war would disrupt their lives, change their routines and force them to find alternative means of living.

Wartime regulations and the building up of the Samoa Defence Group changed peoples' perceptions of land and resources and the meaning attached to them. Most of the cultural obligations and institutions that guided individuals socialisation such as the aualuma did not function properly because their usual spaces were taken up by the military command. At times, people felt dislocated from their own physical and social environments which made Samoan women seem like vagrants in their own homes. Throughout the thesis I have emphasised the argument that the ordinary business of negotiating daily life during the war brought about social change. There were significant turning points in the narratives examined. However, as the narratives have shown, women managed to exercise their agency even though other forces such as the church and cultural obligations weighed heavily on them. They show the resilience of the human spirit.

The churches were critical institutions that had central places in women's lives. The interviews conducted for this research enabled some women to reflect upon the churches' influence on their lives during the war. Their reflections are significantly important because they confirm what we know and surprise us of what our assumptions 
are about Samoan women's wartime relationship with the churches. The majority of the women revealed that there was a disconnection between young women. Most of the women claim the churches were not useful to them during the war as spiritual nurturers. Many believed that the war was a missed opportunity to improve women's position within the churches other than schools. The questions raised by this particular finding are also pathways to understanding women's relationships with the churches in this period. It is a reminder too that our shared history is always partial and further considerations is required to find the essences of such dissatisfactions with the churches during the war.

On the other side of the same coin, the war heightened the pre-war tensions between Samoan women's agency and the power of the churches. The colonial administrations discounted the churches' authority. Despite the clergy's reluctance, the churches provided spaces in which American troops lived and socialised with the Samoan population, creating social situations that were difficult to control. The archives also show how the churches saw the war as a blessing in disguise, an opportunity to benefit from the new worshippers who had 'cash'.

Wartime popular culture in its many forms contributed to the rapid absorption of new ideas and the adaptation of cultural practices. Women's engagement with wartime popular culture resulted in 'on the ground changes' that stimulated social transformation. These too should be appreciated as significant historical moments in their own right. Women articulated their engagement with wartime popular culture to make new experiences relevant to their current realities and less threatening in the long run to their families, villages and culture. Transformation was a way to keep these factors in balance. I have argued here that people's daily engagement with wartime popular culture encouraged the personal will for social transformation from within the confines of Samoan social structures. The mundane nature of wartime life has tended to diminish the historical significance of such daily engagements as a stimulant of social change, making them less likely to be seen as turning points in history because too plain, too ordinary to demand historians' attention. Samoans were introduced to new items of consumption by the marines. Candies, cookies, flour and sugar entered the Samoan diet. Items like shampoo, dynamite, books and other goods brought by the US military for the marines were introduced to the Samoan women and their families. Popular 
foodstuffs had the power to change a generation's diet. The wartime substitutes such as rice, flour and sugar continue to affect the population today. Movies, songs, dancing and reading books all made their marks on Samoan society as well. The engagement with wartime popular culture and the new tastes that Samoans acquired for these items are examples of how wartime experiences subtly invaded our old ways. The changes at the grassroots lasted a long time as people continue to enjoy the faapapa and the cocoa rice today, food that contains a lot of sugar.

As the findings indicate, women's engagement with wartime popular culture involved an immersion into other people's cultural representations of them. The 'dusky maiden' and the 'hollynesian' examples were certainly played up during the war: in the weekly socials, at the makeshift cinemas and even on daily basis. Many of my informants were young and unaware of such categories. Returning to these memories of engagement through their reflections in the interviews the women discovered how they were subtle agents of change, accommodating other people's representations of themselves.

The discussion of women's sexual encounters with the American servicemen has highlighted the many forces that competed to influence women's sexual mores. It underscores the notion that sex is power. Whoever controls women's bodies and affects their ability to understand the cultural codes afforded to their bodies, controls their agency as well. The discussion illuminates the variety of sexual encounters that took place during the war. Some women observed sexual encounters while others, either married or single, made conscious decisions to have consensual sexual relationships with American GIs. Others were victims of sexual violence. Some became pregnant and had babies, but many did not. Those who did not often escaped censure.

The popular idea that Samoan women's wartime sexual encounters were characterised by an unrestrained morality is incorrect. Samoan women had a variety of sexual encounters during the war and their narratives speak volumes about the joys and pains of such life-changing moments. Through the women's narratives we see social transformation as negotiated by individuals at the personal level. The story of Samoan women's wartime lives also shows that social transformation is not a singular linear process of events and unique experiences. Social transformation also comes from individuals' negotiation of the circumstances that present themselves in the most 
extraordinary times. Yet at the heart of all this change was the concern to ensure that the balance between the culture and the self was in harmony.

What does it mean to know more about Samoan women's wartime lives? This thesis has deepened our understanding of Samoan women's wartime experiences. The narratives of Samoan women in this study have given us a renewed and more in-depth understanding of their wartime lives and shown the old views of Samoan women as hypersexualised beings to be inadequate. Their responses to the wartime conditions shaped their lives and reflected on their roles and relationships. The narratives can also be a part of the healing, about rediscovering their wartime selves, and they allow us to take that journey with the women. Paying attention to women's experiences and wartime situations and the use of oral history is very important for bringing forth the hidden histories that exist within our communities. When these histories are known, they revitalise our confidence in and inform appreciation of our history.

Women's lives changed, but their memories survived as did the meaning of their wartime experiences. The reawakening of memories of traumatic experiences can be difficult, but at the same time it relieves the holder of the pressure and the load they have carried. These were lifetime memories, histories and knowledge, connected to aspects of their lives and the lives of their ancestors as well. The women questioned themselves, and shared their understandings of their wartime encounters. This new history becomes the new map that will inform the next generation who will ask questions about what Samoan women did during the Second World War. After doing this study, I now have a more nuanced understanding and appreciation of Samoan women's wartime lives. This thesis is a record of Samoan women's wartime experiences showing how they overcame obstacles in creative ways, exercising their social agency to effect social transformation. Their narratives about their wartime roles, their engagement with the church and popular culture and their sexual encounters add to scholarship on women and war.

This research overcame many a challenge. Timing was the crucial factor that dictated the scope and the depth of this research. Twelve of the thirty two individuals interviewed for this study have now passed away. In the twilight of their years, they 
shared their wartime lives. Their contribution to history enables others to see wartime Samoa. They will be muses of Samoan history long after they are gone.

There is a future for this research. I started with four aspects of Samoan women's lives, but the thesis has touched on some other areas of enquiry. For example, there is the potential for further research into: wartime diet and health, tracking the origins of noncommunicable diseases in Samoa; the Samoan songs that record women's wartime encounters; women's wartime education and nursing. Exploring the fine lines in the wartime relationship between Samoan women and the different church denominations is definitely an area to explore. Other tangents of interests may include Samoan women's beauty regimes and fashion and the influence of the trading companies operating in Samoa during the 1920s. Some of the latter are still in operation so the archival records will not be a challenge. The priority though should be focused on collecting life stories about the Samoans who witnessed the war in Samoa. This is a high priority because the opportunity for the wartime generation to contribute to this narrative will soon be gone.

The history of Samoan women's wartime experiences did not begin with me. As a storyteller and as a historian I facilitated this narrative with my interpretations. The Samoan women were the real historians. Their wartime lives are the new strands woven into our narratives. Their stories become unique motifs in the tapestry of Samoan women's history. I now bring it forth for you, the future generation.

Ua alu atu le afi, ua alu atu le afi, e! 


\section{Appendix 1: Participant Information Sheet}

\begin{tabular}{|l|l|}
\hline \multicolumn{2}{|c|}{ RESEARCH INFORMATION SHEET } \\
\hline Project Title: & \begin{tabular}{l} 
Samoan Women's Wartime Experiences, 1939-1944. \\
\hline Researcher:
\end{tabular} \\
$\begin{array}{l}\text { Louise Mataia-Milo, School of History, Politics, Philosophy and } \\
\text { International Relations, Victoria University of Wellington }\end{array}$ \\
\hline
\end{tabular}

Greetings and Talofa lava. I am a PhD student in the History Programme at Victoria University of Wellington. As part of this degree I am undertaking a research project leading to a thesis. The project I am undertaking aims to examine Samoan women's experiences during the Second World War. The research will seek in particular to explore four aspects of their experiences. These are women's roles in their families and the village, their wartime engagement with the church, the world of the traditional midwife during the war and lastly, their engagement with wartime popular culture.

\section{This research project has received approval from the Victoria University Human Ethics Committee.}

I invite Samoan women in the age range of 83 to 95 to participate in this research.

You have been identified as a possible participant for this research and I would like to invite you to be interviewed for this research project. Before you decide, you need to understand why the research is being done and what it will involve for you. Please take time to read the information carefully. Ask questions if anything you read is not clear or if you would like more information. Take time to decide whether or not to take part.

As a willing participant in this research, you will be asked to be an interviewee in a recorded interview. I will ask you to share your personal views about your experiences of life in Samoa at the time of the war and in the years before and after. You may also be asked if you have any photographs or other wartime objects you wish to show that may be useful to this research.

Your participation in this research is entirely voluntary. The interview involves an openquestioning technique. The nature of the questions will depend on the way in which the interview develops and if the line of questioning develops in such a way that you feel hesitant or uncomfortable you may decline to answer any particular question(s) and/or may withdraw from the project without any disadvantage of any kind.

The interview will be digitally recorded and indexed by me. The index transcript will be given to you to verify the accuracy of the information and clarify your intended meaning. It is also a chance for you to add any other information or remove any commentary from the record. The interview process and information analysis for this project will be carried out from August 2014 to April 2015. You can withdraw from the project without any disadvantage by April 30, 2015. 
The recordings will be stored in the Alexander Turnbull Library Oral History and the University of Victoria Library. While the project is being completed only the researcher and the two supervisors will have access to these recordings. You have a choice about what happens to your interview at the end of this project. You may consent to the digital recording being archived for historical posterity or you may ask that it be destroyed once the project is completed. You may also allow that I keep a copy of the interview confidentially. As a voluntary contributor to this research you have a choice to either have your own name used in the final thesis and any publication or ask that a pseudonym is used instead.

This research project is for academic purposes. Any information you share in the interview will contribute to the writing of the $\mathrm{PhD}$ thesis, academic research papers and presentations. It is my intention to publish the research findings in a book.

The research project is partially funded by the University of Victoria and myself. Your participation in the project is greatly appreciated, and you will receive a small gift as a symbol of my appreciation.

I sincerely hope that you will be able to help with this important research project. If you agree to take part please complete the consent form attached. We can schedule a time suitable for a pre-interview meeting so I can discuss any further questions you have about the project. We will then organise a time for a recorded interview. The contact details for this research are at the end of this document.

Louise M.T. Mataia-Milo

PhD Student

School of History, Politics, Philosophy and International Relations, Victoria University of Wellington

Office: 064044638935

Mobile: 0640223645873

Samoa Contact: 06857228843

American Samoa Contact number: tbc

louise.mataia@,vuw.ac.nz

Supervisors:

Dr. Adrian Muckle

Senior Lecturer

School of History, Politics, Philosophy and International Relations

adrian.muckle@,vuw.ac.nz

064044636773

Prof Charlotte Macdonald

Professor of History

School of History, Politics, Philosophy and International Relations

charlotte.macdonald@,vuw.ac.nz

064044636761 


\section{Appendix 2: Consent Forms}

\section{TA’UTINOGA O LE MALIEGA A LE UA FILIFILI E AUAI I LENEI SAILI'ILIGA}

Manulauti: O aga ma a’afiaga i tamaitai Samoa o le Taua Lona Lua o le Lalolagi.

Ua mae'a nei ona ou faitauina le Itulau o Fa'amatalaga e uiga i le saili'iliga o lo'o faia nei ma ua ou malamalama i ai. Ua fa'amalieina foi a’u fesili sa i ai.

\section{Fa'amolemole tusi mai le fa'ailoga o le fa'asa'o $\sqrt{ }$ i totonu o le pusa e fa'ailoa ai lou finagalo:}

Ua ou malie atoatoa ou te auai i lenei saili'iliga.

Ou te manao i se kopi o lau fa'atalatalanoa e aumai mo au.

Ua ou malie e fa'a'aoga fa'amatalaga mai i lenei fa'atalatalanoaga i se lomiga.

Ua ou fa'atagaina le fa'a'aogaina o:

$\square$ lou igoa i se lomiga.

$\square$ se igoa e ese mai i lou igoa moni i lenei lomiga.

Ua ou avatu le fa'atanaga e fa'a'aoga ai ni mea faitino e pei o ata, tusitusiga ma isi mea fa'apena, na ala atu ia te au i lenei lomiga.

$\square$ Ou te tu'u atu foi lau maliega ma le fa'atanaga mo nā o lē o lo’o fa'aulu'ulu i ai lenei sailiga, e nā o ia lava ua ou fa'atagaina e teuina le kopi o lenei fa'atalatalanoaga.

$\square$ Ua ou malie i se kopi o lenei fa'atalatalanoaga e teuina lelei i le Faletusi o Alexander Turnbull Library ma le Faletusi o le Iunivesite o Vitoria, Ueligitone.

Ou te manao e fa'aleagaina ma fa'atamaia le kopi o lenei fa'atalatalanoaga pe a mae'a lenei saili'iliga.

Ua ou mautinoa ma ou malamalama o lo'u auai i lenei saili'iliga ua faia lea i lau maliega. Ua ou iloa e mafai lava ona ou fa'amavae ma lenei poloketi e aunoa ma se fa'amatalaga o so'u afaina ae e le'i o'o lea i le aso 30 Aperila 2015. O le a fa'aleaogaina foi so'u sao i lenei saili'iliga.

Suafa o lē o le à fa'atalatalanoina:

(Fa'amolemole se'i tusi lima mai)

Saini o le o le ā fa'atalatalanoaina:

Aso o le Fa'atalatalanoaga: 


\section{CONSENT FORM FOR PARTICIPANTS}

\section{Project Title: Samoan Women's Experiences during WWII.}

I have read the Information Sheet concerning this project and understand what it is about. All my questions have been answered to my satisfaction.

Please tick $\downarrow$ the statements to give your consent:

I agree to take part in this project.

I would like a copy of the interview to be made available to me.

I agree that information from this interview may be used in a publication

I consent to the use of:

$\square$ my own name in the publication.

$\square$ a pseudonym in place of my name in the publication.

I give permission for any photos or any other physical material that I provide to be used in the publication.

I am happy for the interviewer to retain a copy of the interview in their personal possession as long as it remains confidential to them.

I am happy for the interview to be archived at the Alexander Turnbull Library and at the Victoria University of Wellington Library.

I would like the recording of the interview to be destroyed, once the research has been published.

My participation in the project is entirely voluntary. I understand that I may withdraw myself (or any information I have provided/ including any visual, audio and tangible objects) from this project by the 30 April 2015 without having to give reasons and that all information gathered from me will be destroyed.

Name of Research Participant (Please Print):

Signature of Research Participant:

Date of Interview: 


\section{Appendix 3: Questions for Oral History Interviews}

\section{Interview Outline and Questions Guide}

The following is the outline of the interview topics and questions to use as a guide to the recorded interview. The interviews will be conducted using open ended question technique. The questions may change depending on the development of the interview and the experiences of the interviewee.

\section{Biographical Questions}

What is your name? Where and when were you born? Where did you grow up? Where have you lived? Where did you do your schooling? Who were your parents? When were you married? Who did you marry? How many brothers and sisters? How many children did you have and when were they born? What jobs have you had? What do you do for a living now?

$\mathrm{O}$ ai lou igoa? $\mathrm{O}$ fea ma anafea na e fanau ai? $\mathrm{O}$ fea na e soifua mai ola ai? $\mathrm{O}$ fea le nuu sa e nofo ai? $\mathrm{O}$ ai aoga sa e aoga ai? $\mathrm{O}$ ai ou matua? $\mathrm{O}$ anafea na e faaipoipo ai? $\mathrm{O}$ fea le nuu na lua faaipoipo ai? $\mathrm{O}$ ai lou toalua? $\mathrm{E}$ fia ou tuagane ma ou uso? E toafia lau fanau, a'o a aso fanau? $\mathrm{O}$ a galuega sa e faigaluega ai? $\mathrm{O}$ le a lau galuega o fai e tausi ai oe I le taimi nei?

\section{Before the war}

1. What was life like for you as a young Samoan woman in your family before the war? Where did you live? What did you do normally? Was there a routine? Can you say that this was the norm for Samoan women at this time? Can you describe some of the things you can remember?

I le vaitaimi o e talavou, o a ou tiute ma au galuega fai I le aiga a'o le'I tupu le taua? $\mathrm{O}$ fea sa e nofo ai? $\mathrm{O}$ a au galuega masani ona fai? E iai se faasologa masani o ou tiute I aso taitasi? Faamatala nisi o galuega o e manatua?

2. What was your relationship with your parents/ family like? What did your parents do for a living? What were your parents' expectations of you? Were you told about this? What were the expected values of a Samoan woman when you were young? Was your mother responsible for teaching you these values or were there other women or people who helped with this? How did they do it?

I lou olaga talavou, o le a se faamoemoega o ou matua mo lou olaga talavou? O le a sou iloa I le taua o lou olaga talavou I lea vaitaimi? Sa faamatala ma fautua atu lou tina le taua ole olaga talavou o se tamaitai Samoa I lea vaitaimi? Oa ni ana tala na fai atu ia te oe?

3. How well did you follow these values/ roles? Did you readily accept your roles before the war? Why/ Why not? 
Pe sa e taliaina ou tiute ma gafa sa aoaoina atu ia te oe? Oa ni mafuaaga sa e le fiafia ai I ou tiute ua maea ona tuumatamaga. Oa foi ni mea sa e fiafia I ai I ou tiute faatamaitai I le aiga?

4. What about during the war, did you notice any changes in your roles and your relationship with your family? Examples? In your opinion, what was the one thing that caused all this?

Ae a le taimi o le taua, pe sa e maitaua le eseesega o ou tiute mai taimi ua tuanai? Aisea le mafuaaga. Sei aumai se faataitaiga faamolemole po'o le a sou mau/ taofi i le mafuaaga o lenei suiga?

5. What was a favourite pastime activity for young Samoan women? Was this the normal thing for young Samoan women to do? Why?

O le a se galuega, se taaloga, se faalapotopotoga sa fiafia iai tamaitai talavou I lou vaitaimi? O se mea masani lea sa fiafia iai tamaitai e fai? Sa iai la se suiga o ia mea faapea ma uiga o tamaita'I ile taimi ole taua? Ete silafia le mafuaaga?

6. What sort of music did you listen to before the war? Did your family own a radio? How did you get music? Do you have a favourite type of dress, food that you loved before the war? Did you do all your socializing in your village?

Oa itu aiga musika sa e faalogologo ai I le taimi ae lei faia le taua? $\mathrm{Na}$ iai se leitio a le tou aiga? Afai e leai, e faapefea ona maua au musika. Oa ituaiga ofu na fiafia iai tamaitai I lea vaitaimi o le olaga - aea

meataumafa? Sa tele ni mafutaga ma ni faatasiga na e auai atu I ai I le tou nuu?

7. What were some of the social clubs/ groups you heard of when you were young. Was it a normal thing for women to go to a club? Did this change during the war? Why? How? Did the old people at the time approve of it? Why/ Why not?

Oa ni fale-kalapu na masani ona e faalogo i ai I le taimi o e laititi ae lei faia le taua? Ae a le taimi na maea ai le taua? O se vaaiga masani le o o tamaitai I le kalapu? Na sui lea vaaiga I le taimi o le taua? I le fea le itu? O lea se tala a le au matutua I lea aga?

8. Did you join the aualuma? When, how old were you when that happened? What was it like? What are some of the things you did as a group? What was the cultural significance of these group events? Was it a good thing to join the aualuma? Were there other groups that young women of your age joined? Can you name them? Did these change when the war happened? How/Why/why not?

Sa e auai ile aualuma a tamaitai? O le a le tausaga lea, ae ua fia ai tausaga o lou matua? Sa e fiafia e auai I lea aualuma? O a nisi o mea sa outou faia faatasi ma isi tamaitai ole aualuma? O le a se taua o le aualuma I le aganuu a Samoa? Sa iai se suiga I galuega faa-aualuma ile taimi ole taua? O le a le mafuaaga o nei suiga?

9. Did going to the aualuma require your parents' permission or was it something that you just went to? What was the structure of the aualuma? Where were you located in this structure? What about now?

$\mathrm{O}$ le auai ile aualuma e manaomia ai se faatagaga mai matua, pe ete alu lava oe I lou loto fuatiaifo? O le a le faatulagaina ole aualuma? I lea 
vaitaimi, o gafea o lea faatulagaga ole aualuma e iai oe? Ae a la le taimi nei, o gafea o lea faatulagaga ua e iai?

10. Who was responsible for instructing the women in the structure of the Aualuma? Was the aualuma affected by the village politics at the time? How? Who was the person with the greatest authority within the Aualuma? How do these individuals get to these positions of authority? $\mathrm{O}$ ai le Sa'oaualuma ae po o a foi le faavasegaina o le aualuma? $\mathrm{Oa} \mathrm{ni}$ aafiaga o le faagaioiga o le aualuma i upufai a le nuu I le taimi o le a oo mai ai le taua. E mafai ona e faaata mai lea vaega faamolemole. O ai o le aualuma e uumia le malosi ma le pule? E faapefia ona maua pe ausia e se tamaitai lea tulaga?

11. Did you notice any power struggle within this grouping during the war? What issues were of a significant point of contention? How did this affect you as a young woman and your relationship with other women?

Oa ni mataupu na ave I ai le faamuamua a le aualuma I le taimi o le taua poo le taimi foi ua amata ona iloa e tagata o le nuu o le a faia se taua? $\mathrm{Na}$ iai ni feteenaiga I le lotoifale o le aualuma I le taimi o le taua? $\mathrm{O}$ a ni mafuaaga? O le a se aafiaga o tamaitai I nei feteenaiga?

12. Did these power struggles extend outside of the group to families/ church/? How? How was this played out in the Aualuma and in your family before the war? What about during the war? What do you think was the key element for this change?

Pe sa e maitauina le sopo atu I tua o le li'o o le aualuma o ia feteenaiga agai I totonu o aiga ma le ekalesia? Aisea le mafuaaga? Pe sa faatitino I le taimi o taua?

13. What about your mother? Was she in the Aualuma as well or was she in a different social group? Did you hear her talk about similar type of things?

Sa auai lou tina I le aualuma I lea vaitaimi, pe ese se vaega e iai? Sa e faalogo I nisi faalapotopotoga faapei o le aualuma o faamatala e lou tina?

14. What about the church? What values did the church teach you how to behave? Can you name them please?

Ae a le tulaga faalelotu? Sa aoaoina oe ele lotu i mea e ao ona fai, ma mea e le faia e tamaitai? E mafai ona e faailoa mai ia mea faamolemole?

15. What about in the mission schools? What was the normal curriculum they taught?

Ae a aoga ale Lotu? O a mea sa aoaoina I aoga a le Lotu?

16. What is your understanding of Samoan women's power relations? How was this played out in the Aualuma and in your family before the war? What about during the war? What do you think was the key element for this change?

O le a lou silafia I le malosiaga o faasinomaga o tamaitai I faiga aualuma I totonu o afioaga? E faapefea ona faatino lea malosiaga I totonu o aualuma ma lou aiga, a'o le'I faia le taua? Sa afaina pe sa iai ni suiga I lea malosiaga ile taimi ole taua? E te silafia le mafuaaga taua o lea suiga?

17. What about your mother and other women of the family, what did she/ they do for a living? What were her roles in the family and in the village and the church? How was their role different from yours? 
Ae faapefea lou tina ma isi tamaitai o le aiga? Oa latou mea na fai e tausi ai le aiga? Oa latou gafa I le aiga ma nuu faapea le ekalesia? Ae a oe, e tele se eseesega o ou tiute ma tamaitai o le aiga?

18. Did the US Naval administration/ New Zealand colonial administration have much to do with women at the time? Were they seen in the village often?

I lea vaitaimi o e talavou, sa iai se aafiaga o tamaitai I pulega a Niu Sila?

Sa oo atu ni tagata papalagi Niu Sila I tua I nuu ma afioaga

19. What did the colonial administration focus on before the war? How did these affect the Samoan women? Can you describe the general characteristics of the adminstrator's relationship with the indigenous women?

Sa iai ni tulafono poo ni aiaiga e aafia ai tamaitai I lea vaitaimi? $\mathrm{O}$ a ia tulafono, ae faapefea ona iloiloina? Sa iai se fesootaiga o le pulega a Niu Sila ma tamaitai Samoa, ona o nei tulafono ma aiaiga?

\section{The coming of the war}

1. Can you tell me your earliest memories of the coming of the war? What were you doing when you first heard about the coming of the war?

E te manatua le taimi muamua sa e faalogo ai ole a faia le taua? $\mathrm{O}$ a au mea na fai I lea taimi, ae o fea foi na e iai. Ua fia ou tausaga I lea taimi??

2. Were there any notices in the paper from the New Zealand / US Naval Administration?

Sa iai ni faasalalauga mai le ofisa o Niu Sila po'o le ofisa o le fuavaatau a Amerika e uiga ile taua? E mafai ona faamatala mai?

3. Was there a special village council meeting about it? Sa fai se fono a Alii ma Faipule ole nuu e uiga ile taua?

4. What was the general mood? What did your family and the village thought about the war? What did they do to prepare for the war?

$O$ le a se lagona sa iai ile nuu ina ua faalogo ile taua? Ae a lou aiga, sa iai ni lagona e uiga ile taua? Sa iai ni tapenaga a le nuu mo le taua?

5. What did the old people say about the war? At church? At the Aualuma? What did the people say about the American marines before they actually arrived to Samoa/US Samoa/ your island/your village? Were any of these stories true?

O le a se tala a tagata matutua e uiga ile taua? Ae a le Lotu? Ae a le Aualuma? Sa iai ni faamatalaga a le nuu e uiga I maligi ma papalagi o le taua, ae le'I taunuu atu nisi I Samoa?

6. Can you describe some of the scenes in town or in your village when the American marines arrived? Were the people excited about it?

O a ni vaaiga poo ni faailoilo o le taua na muamua e vaaia? Se'I faamatala mai ia vaaiga I totonu o lou nuu? O le a le tausaga lea? Sei e 
faamatalaina mai se vaaiga I le taimi na omai ai fitafita Meleke? O le a se faalogona faaalia o o tatou tagata?

7. What were some of the things that you were asked to do to accommodate the arrival of the 'guests'?

Pe sa fa'atalosagaina outou e faia ni tonu aua le taliga o 'malo' o le taua?

8. Did your family host any of the soldiers in your home? What were you told to do? Can you explain how your family hosted these Americans?

Sa iai se fitafia sa avea ma malo masani a le tou aiga? $\mathrm{O}$ a ni gaioiga masani sa faatagaina faaletulafono aua le tausiga o le malo? Sa fiafia lou aiga e tali nei fitafita?

9. Did the New Zealand administration say anything about how to host the soldiers? Who did your family get their instructions from?

O lea se tala a le pulega a Niusila I le taliga malo? O ai e aumai ai faatonuga mo le taliga malo I le vaega au a Amerika?

10. What were the normal things you had to do as a host - dance, serve food, conversations? How did the soldiers take this 'hosting'? Can you remember some of the comments the soldiers made about you or the women who hosted them? Were you asked to do anything else?

Oa gaioiga masani e fai pea tali malo I fitafita? Faafiafiaga? Tausiga? Talanoaga? $\mathrm{Na}$ fiafia alii fitafita I taliga o I latou? Oa ni tali o alii fitafia na fai I tamaitai sa gafa ma le tausiga o I latu? Na iai ni manaoga o alii fitafita na talosaga atu ai ia te outou?

11. How did the war affect the aualuma's activities? Were there things that you used to do as young women in the aualuma that you could not do during the war? Can you give some examples and explain why this happened.

$\mathrm{Na}$ faapefea ona suia e le taua ia galuega fai soo a le aualuma faapea tina taitasi? Oa ni faataitaiga o ni gaioiga ua le toe faia I le taimi o le taua?

12. What were some of the things you did as a young Samoan woman during the war? Were they the things you wanted to do?

Oa ni mea na masani ona e faia I taimi ua mavae sa le mafai ona toe faia I le taimi o le taua? Sa e manao e faia lea tulaga?

13. Did the war affect your relationship with your mother or with other women? Did you notice any difference? What were these differences? Why?

Sa aafia le lua mafutaga ma lou tina I le taua? Aea ia le tou va nonofo ai ma isi tamaitai o le nuu ma le aiga. Oa ia suiga sa e maitauina? 
14. Did your roles and responsibilities change during the war? What was significant about these changes?

Sa iai ni suiga I ou tiute ma au galuega I le vaitaimi ole taua? E iai se taua o ia suiga?

\section{Women, WWII and the Church}

1. Did the war affect the church's role as a provider of spiritual nurture and education for you as a Samoan woman? How?

I lou tulaga faatamaitai Samoa, e faapefea ona aafia galuega ma aoaoga faalelotu I le taua?

2. What were some of the church activities were you involved in? What was the level of your involvement?

Oa mafutaga ma gaioiga a le lotu sa e auai atu I ai? O le a sou sao I lea vaega?

3. What were some of the changes you noticed as a young person during the war? Why did the changes take place?

$\mathrm{O}$ a ni suiga ma ni aafiaga I tulaga faalelotu ile vaitaimi ole taua? O a mafuaaga o nei suiga?

4. Did the church invest a lot of time and resources on moral instructions of women during the war? What were they and how were these 'morals' taught?

Faamata na tele se tapenaga a le lotu mo le aoaoga ofaakerisiono I tamaitai I le vaitaimi o le taua? $\mathrm{O}$ ai o le aufaigaluega na gafa ma lea galuega?

5. Did you attend the mission schools or the village schools?

Pe sa e aoga I se aoga a le lotu po'o se aoga a le malo? Na masani na o atu ni fitafita I le tou aoga? Aisea?

6. Did you talk with any soldiers? What did they say to you?

Sa e talanoa ise fitafita? $\mathrm{O}$ a ni faamatalaga sa fai atu ia te oe?

7. What about social activities such as school dances etc., were there specific types of dances taught to girls? When did this happen?

Sa iai ni faiga siva, siva ale aoga sa faia I ia taimi? Sa iai ni siva faapitoa sa aoaoina mo tamaita'i? O le a le tausaga lea?

8. What subjects were taught at the mission schools before the war? Did these change when the war happened? 
O a mataupu sa aoaoina I aoga faalelotu a'o le'I faia le taua? Sa iai ni suiga I nei aoaoga ile taimi ole taua?

9. Why do you think these changes happened?

O le a sou iloa I mafuaaga o nei suiga?

10. Do you think these changes in the churches approach affect you as an individual?

Faamata o nei suiga faalelotu ua aafia ai lou olaga?

11. Did they benefit you in the long run? How?

Faamata o nei suiga sa aoga ia te oe mole lumana'i? E faapefea ona aoga?

12. What about the skills being taught at school at the time? Were you taught short-hand, typing, accounting, book-keeping at school? Can you give some examples?

O a ni mataupu aoga sa aoaoina ai oe i aoga i lea vaitaimi? Sa aoaoina mataupu tau tupe maua ma tupe fa'a'alu ma mataupu tau tusitusi ma lomitusi?

13. Did these help you make better choices than those available to your mother when she was young?

Sa aoga nei mataupu ia oe mo lou lumanai ma le faamoemoe e sili atu nai lo'o avanoa sa maua e lou tina

14. Can you tell me some of the highlights of your schooling life as a young Samoan woman during the war? How different was it from before and after the war?

Fa'amatala mai nisi o mea taua I lou olaga aoga ile vaitaimi ole taua? E iai se eseesega o nei mea ile vaitaimi a'o le'I faia le taua, male vaitaimi ua mae'a le taua?

15. In your own opinion, did the war change the church's way of thinking about women? In what way?

O le a lou taofi, sa tele se suiga o aoaoga ma le vaaiga a le lotu i tamaitai? I le a le itu? Sei aumai ni au fa'ataitaiga fa'amolemole?

\section{Samoan maternal health and traditional midwifery and sex during WWII.}

1. Based on your experience at the time, can you tell me how your community saw the role of the traditional midwife?

O lea lou taofi I le matafaioi ma nafa o le faatosaga Samoa?

2. Before the war was it normal for women to have home births or were they taken to the hospital?

Ae lei faia le taua, o ai sa masani ona o ai tina maitaga e ola ai? 
3. How many traditional midwives in the village at the time? Were there many in your village aualuma? Were they respected in this circle because of their role as a healer? What did you think of these women?

E toa fia faatosaga o le tou nuu I le taimi o le taua? E sasao uma nei faatosaga I le aualuma? Faletua ma tausi? Komiti tumama? O le a le tulaga o faaaloaloga e ave i e sa gafa ma le faiva o le faatosaga?

4. Were there times that the Aualuma requested a midwife's comments with regards to maternal health? If this happened, what did she talk about? Did this occur often during the war or was it done in a subtle manner? Can you describe how this topic was handled by the women as a group? Was this different when your mother or other women in the family talked about it?

$\mathrm{Na}$ i ai se taimi na talosagaina ai e le Aualuma le fesoasoani a se faatosaga mo se aoaoga I tamaitai? Oa ni mea na talanoa ai. Na tupu lea mea I le taimi o le taua? $\mathrm{Na}$ ese mai ia faamatalaga mai lau talanoaga masani faatamaitai ma lou tina faapea isi tamaitai o lou aiga?

5. What did you and your friends think about her advice? What did your mother think about the midwives?

O lea lou mafaufau I ai e uiga i le aoaoga ma timaiga a le faatosaga? $\mathrm{Na}$ fiafia I ai lou tina I lea mea?

6. Did you have children using the help of a traditional midwife? What were some of the things you had to do before and after the birth?

I taimi o ou maitaga, sa e faaaogaina le fesoasoani a le faatosaga faasamoa? Oa ni mea na faatonuina oe e fai?

7. During the war, was there much exchange between the traditional midwives and the soldiers or the colonial administration?

I le taimi o le taua, na tele ni taimi na fetufaai ai tomai faaletaulasea a le vasega o faatosaga samoa ma alii fitafita meleke ma le pulega faakolone niusila?

8. How did the war influence the role of the traditional midwives? Did your mother approve of this nature of the traditional midwife?

$\mathrm{Na}$ faapefea ona aafia le nafa o tina faatosaga I le taua. $\mathrm{Na}$ auai le manatu o lou tina I le natura o le galuega faatosaga Samoa?

9. Were there more births at the hospital or in the villages?

I le taimi o le taua, na tele atu ni tina sa fananau I le falemai nai lo o tua I le nuu?

10. Was there an awareness that traditional midwives were sought after to terminate any unwanted pregnancies during the war? Did this happen a lot before the war? Why/ why not?

Sa fesiligia faatosaga e tamaitai ua tofale ina ia faatamai'a ia le to? Faamata o se aga masani lea a tamaitai samoa I le taimi o le taua? E te silafia po'o a aiaiga e ona mafai ai ona faatinoina se faatamaina o se pepe I le faasamoa? 
11. Was this aspect of the role frowned upon during the war? Can you explain how, why or why not? Are there specific situations that you know of in your village

Sa tele ni tala e fai agai lea vaega o le galuega faatosaga I le taimi o le taua? E mafai ona e faamatala le vaega lea faamolemole. E te silafia ni vaega na tutupu I lea tulaga?

12. What did the church say about this side of the midwife's role? Were there any specific words used to explain or describe this aspect?

O lea le mau a le lotu I le itu lenei o le galuega faatosaga faasamoa? E iai ni faaupuga po o ni upu faapitoa e faamatalaina ai lenei galuega ma ona vaega?

13. Do you know of any midwife that you grew up with at the time? Who were they?

E te silafia ni faatosaga I le taimi o le taua? O soifua mai pea I latou? E mafai ona e faailoa mai?

Samoan women's engagement with Popular Culture

1. What contact (if any) did you have with US or NZ soldiers? Did you talk with any soldiers? What did they say to you? Did they offer you or any of your friends and relatives any items to consume or books, metal, or any items of clothing?

E faape'I ni a outou masaniga ma fetufaaiga ma fitafita Amerika ma Niusila? Pe sa tele ni tou talanoaga faasamasamanoa ma alii fitafita? Oa ni mataupu sa tou talanoa I ai? Pe na ofa mai e alii fitafita ni meatotino e pei o tusi faitau, mama siliva, ofu ma isi mea faitino faapena?

2. What about social activities such as school dances etc., were there specific types of dances taught to girls? When did this happen?

Ae'a siva ma pese Ia outou aoga ? E iai ni mea faapitoa na aoaoina atu e

fitafita ia te outou poo isi foi tamaiti? $O$ anafea na tupu ai?

3. Were there any public gatherings or socials? Where were these held? Who was responsible for organizing these?

E tele ni mafutaga ma ni faatasiga lautele na fai I lea taimi? I fea? $\mathrm{O}$ ai na gafa ma tapenaga o ia fiafia? E mafai ona e talanoa e uiga I ia fiafia?

4. Were there any women who were running shops, restaurants that you or the people were familiar with? Can you talk about them and what they were especially liked about?

E te silafia ni tina ma tamaitai na fai ni a latou pisinisi e pei o ni fale talimalo, fale aiga I lea vaitaimi? E mafai ona e talanoa I ai poo a latou ituaiga pisinisi sa fai? O le fea o nei mea sa e fiafia iai? Aisea?

5. To what extent did the level of your involvement affect your role in your family and community during the war?

O le a se aafiaga o ou tiute ma galuega faatamaitai I totonu o le aiga ma

le nuu sa afaina I le taimi o le taua?

6. Do you remember any of the things that soldiers brought to Samoa? Books, food, music, fashion etc? 
E te manatua nisi o mea na aumai e fitafita maligi ma papalagi I Samoa?

Pei o tusi, meaai, musika, ituaiga siva, ma nisi?

7. Did you and your peers enjoy the use of these items? Why? Did you share them with some of your family members? What did they say?

Sa e fiafia ma au uo e fa'aaoga nei meaalofa mai papalagi? Aisea? Sa e faasoa atu I lou aiga? O le a so latou lagona?

8. What was the everyday attire for women of your age before the war? Did this change during the war? Why? Did women wear pants before the war?

O a lavalava masani o tamaitai o lau tupulaga sa fai a'o le'I faia le taua?

$\mathrm{Na}$ suia o latou lavalava ile taimi o le taua? Aisea? Sa faia ni ofuvae

fealua'I o tamaitai a'o le'I faia le taua?

9. What were some of the social events you witnessed or took part in during the war? Were you involved in the dance groups that entertained for the American marines at the various camps? Can you describe your experiences of this?

O a ni faafiafiaga poo ni faigasiva sa e auai pen a e iloa sa faia I le vaitaimi o le taua? Sa e auai ise faafiafiaga mo fitafita sa faia I nisi o nofoaga? E mafia ona e faamatalaina nei faafiafiaga?

10. In your village, what did you do as a young Samoan woman during the war? Did you enjoy dancing a new type of dance brought in by the Americans or the New Zealanders?

I le vaitaimi o le taua, o a ou tiute faatamaitai sa fai I totonu o lou nuu?

Sa e fiafia e auai I faigasiva fou faapapalagi ia na aumai e papalagi o le taua?

11. What were some of the songs and dances you can remember from the war period? Did you dance any of them as a young woman during the war?

E te manatua nisi o pese ma siva faapapalagi I lea taimi o le taua? Sa e pese ma siva I nisi o nei siva?

12. Can you tell me, what were some of the popular songs and food items?

E mafia ona e faamatalaina nisi o nei pese ma ni meaai faapapalagi sa iai I lea taimi?

13. Do you think Samoan women were more engaged with wartime popular culture than Samoan men? Why was this? What made it so?

I lou silafia, faamata sa sili atu le fiafia o tamaitai Samoa e auai I

faafiafiaga faapapalagi nai lo tamaloloa Samoa? Aisea? E iai se mafuaaga

e fiafia ai tamaitai Samoa e auai?

14. What about in the area of fashion, what did the American marines bring to the Samoan people? How was this trend sustained? Were there local businesses that brought in American goods after that?

Ae a le vaega o teuga faapapalagi, sa iai ni ituaiga lavalava papalagi, oni mea teuteutino, ma teuteu foliga na aumai e fitafita I Samoa? Faafefea ona maua nei teuga I nuu? Sa iai ni faleoloa e faatau ai nei teuga faapapalagi?

15. Did this popular culture affect your role in your own family? And the community? How?

I le oo mai o nei teuga faapapalagi, pese faapapalagi, ma meaai faapapalagi, sa iai se aafiaga I ou tiute faaleaiga? Tiute Faalenuu? E faapefea ona aafia? 
16. What was the relationship between the soldiers and the women like? How different was this relationship to the Samoan men?

O le a sou silafia I le mafutaga a le tamaitai Samoa ma le fitafita papalagi? O le a se eseesega o le mafutaga ma le tamaloa Samoa?

17. Did your family approve of the use of new items in the home? Why/ why not?

Sa talia e lou aiga le fa'aaoga o mea faapapalagi I totonu o lo outou fale? Aisea?

18. Can you say that your experiences reflect a general picture of Samoan women's experiences?

E te talitonu o lou silafia ma ou lagona i mea sa tutupu I le vaitaimi o le taua, e atagia ai finagalo o tamaitai Samoa sa soifua I lea taimi.

19. Were there changes that the people did not like? What were they and how did the community deal with it?

Sa iai ni tagata sa le fiaifa ini suiga I lea vaitaimi o le taua? $\mathrm{O}$ a nei suiga?

O le a se mea a le afioaga sa faia iai?

20. Are any of the women you experienced the war with still living? Where do they live now?

E te silafia nisi o tamaitai sa outou soifua faatasi mai I le vaitaimi o le taua? E te silafia o fea o soifua ai nei?

21. Is there anything else you would like to add?

E iai se isi au mau e fia faaopopo, poo se mea fo'I e te fia logoina mai ou te le'I talanoa atu ai?

\section{End of interview/Ua mae'a le faatalatalanoaga:}

I would like to thank you most sincerely for sharing your history with me.

E momoli atu le faafetai i lau faasoa mai o lou tala'aga i le taimi o le taua. 


\section{Bibliography}

\section{Primary Sources}

\section{Archives New Zealand, Wellington, New Zealand}

AAEG W3240 950 Box 613 C 311/6/5 1. Countries Series - Western Samoa - Social Affairs - Health 1928-1961.

AAD - LW 3363 Box 333. Censorship World War II 1938 -39.

ACFX 8294 W1510 IT A3 3/15. American Samoa - a General Report by Governor H.F. Bryan - October 1926.

ACGA 8280 IT1 431 EX69/151 1. Evacuation of Women and Children from South West Pacific Territories - WWII.

ACGA 8280 IT1/455. Censorship of Films for Western Samoa - 1920-1936.

AGCA 6051 ROLL 81 German Samoa Archives.

ACGA 8280 IT1 211 Labour - Samoa - General Files.

ACGM 18974 Samoa-BMO2/1/3. Papers Relating to Deputy Administrator Williams, $1915-1918$

AD1 1379 336/1/37. Aliens and Prisoners of War - Civilian Internees from Samoa. Undated.

BBAE 1570 A645 1115/ P520/1953. Stowers, Isabella - Magir, Apia, West Samoa Married Woman.

IT 1287 EX 38/1/2. Census 1945.

IA1 3046 171/2/1. Wartime Administration Arrangements - Proclamations, Regulations - Application of to Western Samoa, Cook Islands, Niue Island.

WAII 1517 DAZ 121/9/B10/5. HQ 3 Division - Office Records - US Forces in Western Samoa Agreement between USA and New Zealand.

\section{Alexander Turnbull Library, Wellington, New Zealand}

Oceania Marist Province Archives. Archives of the Catholic Diocese of Samoa and Tokelau. Pacific Manuscripts Bureau microfilm series. Reels, OMPA 63, 67.

US Naval History Division. "US Naval History of Western Samoa." Micro-MS-0850-1

LMS Samoan District Correspondence with the NZ Administration, 1915-46. MS Roll 08 PMB 0144.

Appendix to Journals of the House of Representative (AJHR)

NZ Administration of Western Samoa (NZAWS) Annual Report 1922

NZAWS Annual Report 1933

NZAWS Annual Report 1939

NZAWS Annual Report 1942

NZAWS Annual Report 1945 
NZAWS Annual Report 1947

National Archives and Records Administration (NARA), San Bruno, USA

T-1182 Records of the Government of American Samoa used in this thesis were made available by Judith A.Bennett.

T-1182 ROLL 18. Records of the Governor's Office - Fono Proceedings, 1900-1950.

T-1182 ROLL 19. Records of the Governor's Office - Fono Proceedings, 1930-1939.

T-1184 ROLL 20. Records of the Governor's Office - Fono Proceedings, 1940-1946.

T-1182 ROLL 32 Part 1. Fono Proceedings, Miscellaneous Papers, 1900-1920.

T-1182 Roll 56. Records of the Attorney General's Office, 1938-1956.

\section{National Museum of Samoa/Archives, Apia, Samoa}

Various photographs

\section{Archdiocese of Samoa Archives, Apia, Samoa}

Various photographs

\section{Newspapers and periodicals}

Western Samoa Mail, 1938-1941.

Pacific Island Monthly, XI, no. 7 (1938) -Vol XX, no. 2 (1947).

The Western Samoa Gazette, 1923-1948

\section{Interviews conducted by Louise Mataia-Milo}

\section{New Zealand}

Hunter-Malietoa, Tuala Falenaoti Terese M. 12 August 2014, Ranui Home, Mount Albert, Auckland.

Laban, Winnie. 22 February 2016, Kelburn, Wellington.

McElhiney, Alice Mary. 4 April 2015, Manurewa, Auckland

Oderharver, Leafaitulagi Theresa. 8 May 2015, Sandringham.

Ryan, Isabella Stehlin. 7 May 2015, New Lynn, Auckland.

Williams, Hedwig Sivao, 4 February 2015. Catholic Bishop's Residence Ponsonby, Auckland. 
Savusa, Nanatiifaleteleife'auatamalii. 12 December 2014, Nu'u'uli.

Pa'au, Saunia. 6 December 2014, Fitiuta, Manu'a.

Malautea, Isapela. 13 December 2014, Lauli'i.

Milo, Saini Mauga. 4 December 2014, Ta'u, Manu'a.

Lauvai, Asuega F. 16 December 2014, Pago Pago.

Tauala Fiu, Alataua. 4 December 2014, Ta’u, Manua.

Iuli, Amanda Galea'i. 26 November 2014, Leone.

Fiti Brown, Tiresa. 12 December 2014, Vatia.

Tiatia, Nila. 13 December 2014, Lauli’i

Alova'a, I'auluao. 14 December 2014, Ili’ili, Tafuna.

Taala Mavaega, Faalogo. 17 December 2014, Ili'ili, Tafuna.

Seumalo, Seumalo Ukulele. 2 December 2014, Vailoa Tai, Leone.

\section{Samoa}

Atogi, Nonu Masae, 16 October 2014, Paia.

Faalogo, Faalogou Fai Taputu Sone. 16 October 2014, Paia,

Enesi, Tauvaga Lemana. 17 October 2014, Lefagaoali'i Uta, Safune.

Faumuina, Faapusa. 17 October 2014, Matavai, Safune.

Namulau'ulu - Schmidt, Galumalemana Netina Galo. 29 September 2014, Vailele, Vaimauga.

Leota, Tautautasileniualeotaleuluaiali'i. 29 August 2014, Solosolo, Anoama'a.

Leota, Fa'asalafalesuafaoleotatoomata. 30 September 2014, Solosolo, Anoama'a.

Leauna'i, Sister Malia Makerita. 9 January 2015, SMSM Convent, Vailoa, Faleata.

Selesele, Faafouina. 18 October 2014, Vaega, Satupaitea.

Savea, Ana Peletisala. 22 September 2014, Solosolo, Anoama'a.

Soava'a, Malia. 28 September 2014, Moamoa, Faleata

Sooalo Leo, Palepa. 17 October, 2014, Lefagaoali'i, Safune. 
Tupai-Taeao, Faanunumi Rosa. 7 October 2014, Nu'usuatia.

Taupa'u Enesi, Maria Aigailetai. 30 December 2014, Salua, Manono.

\section{Secondary Sources}

Alailima, Fay. Aggie Grey, a Samoan Saga. Honolulu: Mutual Publising, 1988.

Akin, David. Colonialism, Maasina Rule and the Origins of Malaitan Kastom. Honolulu: University of Hawai'i Press, 2013.

Amerika Samoa Humanities Council. A History of American Samoa. Honolulu: Bess Press, 2009.

Anderson, Rosemary E. "The Origins of Cook Island Migration to New Zealand, 19201950." MA thesis, University of Otago, 2015.

Bailey, Beth and David Farber. The First Strange Place: Race and Sex in World War II Hawaii. Baltimore: Johns Hopkins University Press, 1994.

Baker, Kimeya. "The Contagious Diseases Acts and the Prostitute: How Disease and the Law Controlled the Female Body." Journal of Law and Jurisprudence 1, no. 1 (2012): 88-119.

Barradale, Victor Arnold. Pearls of the Pacific: Being Sketches of Missionary Life and Work in Samoa and Other Islands in the South Seas. London: London Missionary Society, 1907.

Bennett, Judith A. and Angela Wanhalla, ed. Mothers' Darlings of the South Pacific: The Children of Indigenous Women and U.S. Servicemen, World War II. Honolulu: University of Hawaii, 2016.

Bennett, Judith A. Natives and Exotics: World War Two and Environment in the Southern Pacific. Honolulu: University of Hawaii Press, 2009.

. "Fears and Aspirations: US Military Intelligence Operations in the South Pacific, 1941-1945." The Journal of Pacific History 39, no. 3 (2004): 283-307.

Bennett, Tony. "Popular Culture: A Teaching Object." Screen Education 35 (1980).

Bessell-Browne, Gwen. The Road to Kokoda and Other Verses. Melbourne: Robertson and Mullins, 1943.

Bindon, James R. "Breadfruit, Banana, Beef, and Beer: Modernization of the Samoan Diet." Ecology of Food and Nutrition 12, no. 1 (1982): 49-60.

Boyd, Mary. "The Decolonisation of Western Samoa." In The Feel of Truth: Essays in Zealand and Pacific History Presented to F.L.WW Wood and J.C. Beaglehole on the Occasion of their Retirement, ed. Peter Munz. Wellington: A.H. \& A.W. Reed for the Victoria University of Wellington, 1969.

—. "The Record in Western Samoa to 1945." In New Zealand's Record in the Pacific Islands in the Twentieth Century, ed. Angus Ross. London: C. Hurst \& Co., 1969.

Brawley, Sean and Chris Dixon, "Searching for Dorothy Lamour: War and Sex in the South Pacific, 1941-45." Australian Journal of American Studies 18, no. 1 (2012): 318.

- Hollywood's South Seas and the Pacific War: Searching for Dorothy Lamour. New York: Palgrave MacMillan, 2012.

Brunt, Tony. To Walk under Palm Trees: The Germans in Samoa. The Museum of Samoa, 2016. 
Buxton, Patrick A. "Brown Men and White in Samoa: Researches in Polynesia and Melanesia." London London School of Tropical Medicine, 1928.

- Researches in Polynesia and Melanesia: An Account of Investigations in Samoa, Tonga, the Ellice Group, and the New Hebrides, in 1924, 1925. London: London School of Hygiene and Tropical Medicine, 1927.

Campbell, I. C. Worlds Apart: A History of the Pacific Islands. Christchurch: Canterbury University Press, 1989.

Campbell, I. C. "Resistance and Colonial Government: A Comparative Study of Samoa." The Journal of Pacific History 40, no. 1 (2005): 45-69.

Campbell, I.C. "To Not Reinstate the Past: Wartime Optimism and Planning for the British Solomon Islands Protectorate," The Journal of Pacific History 42, no. 1 (June 2007): 55-72.

Carey, John J. A Marine from Boston: A First Person Story of a US Marine in World War II: Boot Camp, Samoa, Guadalcanal, Bougainville. Bloomington, Ind.: First Books Library, 2002.

Cato, A. "Fijians and Fiji-Indians: A Culture Contact Problem in the South Pacific." Oceania 26 (1955): 14-34.

Chappell, David A. "The Forgotten Mau: Anti-Navy Protest in American Samoa, 19201935." Pacific Historical Review 69, no. 2 (2000): 217-260.

Charles, Persis. "Women and the Two World Wars: Report on Conference at Harvard." Women's Studies Quarterly 12, no. 2 (1984): 7-7.

Clark, Nancy L. "Gendering Production in Wartime South Africa." The American Historical Review 106, no. 4 (2001): 1181-213.

Cleveland, Les. "When They Send the Last Yank Home: Wartime Images of Popular Culture." Journal of Popular Culture, 18 (Winter 1984): 31-6.

Cody, Joseph F. (28) Maori Battalion, ed. Howard Karl Kippenberger, The Official History of New Zealand in the Second World War 1939-1945 (Wellington: Historical Publications Branch, 1956),

Collingham, Lizzie. "The Taste of War: World War Two and the Battle for Food." London: Penguin Group, 2012.

Consolata, Sister Mary (SMSM). Samoa with Love: Reminiscences of Forty-Five Years. Waltham, Mass: Marist Missionary Sisters, 1991.

Cook, Haruko Taya. "Memories of Japan's Lost War." The Journal of American-East Asian Relations 11, no. 1/4 (2002): 25-40.

Cooke, James. Chewing Gum, Candy Bars and Beer: The Army PX in World War II. Columbia: University of Missouri Press, 2010.

Coulter, John Wesley. The Pacific Dependencies of the United States. The MacMillan Company: New York, 1957.

Crawford, John. New Zealand's Pacific Frontline: Guadalcanal-Solomon Islands Campaign, 194245. Wellington: New Zealand Defence Force, 1992.

Crocombe, Ron, The South Pacific. 7th ed. Suva: IPS Publications, University of the South Pacific, 2008.

Damousi, Joy and Marilyn Lake, ed. Gender and War: Australians at War in the Twentieth Century. Melbourne: Cambridge University Press, 1995.

Darian-Smith, Kate, On the Home Front: Melbourne in Wartime 1939-1945. Melbourne: Oxford University Press, 1991.

Davidson, J.W. "Review of New Zealand's Record in the Pacific Islands in the Twentieth Century by Angus Ross." The Journal of Pacific History 5 (1970): 229-31. 
Samoa Mo Samoa: The Emergence of the Independent State of Western Samoa. New York: Oxford University Press, 1967.

Davis, Natalie Zemon. The Return of Martin Guerre. Cambridge: Harvard University Press, 1983.

. "Decentering History: Local Stories and Cultural Crossing in a Global World." History and Theory 50, no.2 (May, 2011): 188-202.

Denoon, Donald; Firth, Stewart; Linneken, Jocelyn; Meleisea, Malama; and Karen Nero, eds. The Cambridge History of the Pacific Islanders. New York: Cambridge University Press, 1997.

Douglas, Bronwen. Across the Great Divide: Journeys in History and Anthropology. Amsterdam Harwood Academic Publishers, 1998.

Downs, E. A., and H.B. Turbott. Health for Samoa/ Maloloina Mo Samoa. Translated by Ielu Iiga and Atimalala Mama. Wellington: E.V. Paul, Government Printer, 1937.

Dunnigan, James F., and Albert A. Nofi. The Pacific War Encyclopedia. New York: Facts On File, 1998.

Edmond, Lauris ed. Women in Wartime: New Zealand Women Tell Their Story. Wellington: Government Printing Office Publishing, 1986.

Elwell, Ruth. "Popular Culture and World War II." In Popular Culture and World War II: World War II in Asia and the Pacific and the War's Aftermath, ed. Loyd E. Lee. Westport, CT.: Greenwood Press, 1998.

Enari, Lynne. "Fuatino Koke Aiono." In Tamaitai Samoa: Their Stories, edited by Peggy Fairbairn-Dunlop. Suva: Institute of Pacific Studies, 1996.

Enloe, Cynthia "'Gender' Is Not Enough: The Need for a Feminist Consciousness." International Affairs 80, no. 1 (2004): 95-97.

Enloe, Cynthia. Seriously! Investigating Crashes and Crises as If Women Mattered. California: University of California Press, 2013.

Fairbairn-Dunlop, Peggy. Tamaitai Samoa: Their Stories. USP Suva: KIN Publication, 1998.

Falgout, Suzanne, Poyer, Lin and Laurence M. Carucci, Memories of war: Micronesians in the Pacific War. Honolulu: University of Hawaii, 2008.

Field, Micheal J. Mau: Samoa's struggle against New Zealand oppression. Wellington: A.H. \& A.W. Reed Ltd., 1984.

Fiske, John "Television: Polysemy and Popularity." Critical Studies in Mass Communication 3, no. 4 (1986): 391-408.

Francis, Andrew. "To Be Truly British We Must Be Anti-German": New Zealand, Enemy Aliens and the Great War Experience, 1914-1919. Oxford: Peter Lang, 2012.

Franco, Robert. "Samoans, World War II and Military Work." In Remembering the Pacific War, ed. Geoffrey M. White. Honolulu: Center for Pacific Islands Studies, School of Hawaiian, Asian and Pacific Studies, 1991.

Freccero, Carla Popular Culture: An Introduction. New York: New York University Press, 1992.

Friedan, Betty. The Feminine Mystique Harmondsworth: Penguin, 1965.

Friedman, Barbara "The Soldier Speaks: Yank Coverage of Women and Wartime

Work," American Journalism 22, no. 2 (2013): 63-82.

Friedman, Hal M. "The Beast in Paradise: The United States Navy in Micronesia." Pacific Historical Review 62, no. 2 (1993): 173-195. 
Gillespie, Oliver A. The Pacific, ed. Howard Karl Kippenberger, The Official History of New Zealand in the Second World War 1939-1945. Wellington: Historical

Publications Branch, 1952.

Gray, J.A.C. Amerika Samoa: A History of American Samoa and its United States Naval Administration. Annapolis, Md: United States Naval Institute, 1960.

Hall, Stuart. "Notes on Deconstructing 'the Popular'." In Cultural Theory: An Anthropology, edited by Imre Szeman and Timothy Kaposy. West Sussex: WileyBlackwell, 2011.

Harris, R. Carl. Building the Kingdom in Samoa, 1888-2005: History, Personal Narratives, and Images Portraying Latter-Day Saints' Experiences in the Samoan Islands. Heber City, Utah: Harris Video Cases, 2006.

Hau'ofa, Epeli. We Are the Ocean: Selected works. Honolulu: University of Hawai'i, 2008.

Hempenstall, Peter J. Protest and Dissent in the Colonial Pacific. Suva: University of the South Pacific, 1984.

Hollows, Joanne. Feminism, Femininity and Popular Culture. Manchester: Manchester University Press, 2000.

Hooper, Charlotte Manly States: Masculinities, International Relations and Gender Politics. New York: Columbia University Press, 2001.

Horowitz, Daniel. Consuming Pleasures: Intellectuals and Popular Culture in the Postwar World. Pennsylvania: University of Pennsylvania Press, 2012.

Hyde, Pamela. "Managing Bodies--Managing Relationships: The Popular Media and the Social Construction of Women's Bodies and Social Roles from the 1930s to the 1950s ". Journal of Sociology 36, no. 2 (2000): 157-71.

Johnson, Cheryl L. "The Language of Sexuality and Silence in Lillian Smith's "Strange Fruit"." Signs 27, no. 1 (2001): 1-22.

Kaplan, Martha. "Meaning, Agency and Colonial History: Navosavakadua and the Tuka Movement in Fiji. American Ethnologist 17, no.1 (1990): 3-22.

Katrak, Ketu H. "Politics of the Female Body: Postcolonial Women Writers of the Third World." New Brunswick, N.J.: Rutgers University Press, 2006.

Keesing, Felix M. "The Taupo[u]System of Samoa a Study of Institutional Change." Oceania 8, no. 1 (1 September 1937): 1-14.

. Felix. Modern Samoa: Its Government and Changing Life. London: Allen \& Unwin, 1934.

Keesing, Roger M. Custom and Confrontation: The Kwaio Struggle for Cultural Autonomy Chicago: University of Chicago Press, 1992.

Kelly, Joan B. Women, History, and Theory the Essays of Joan Kelly. Chicago: University of Chicago Press, 1986.

Kennedy, Joseph. The Tropical Frontier: America's South Sea Colony. Mangilao: Micronesian Area Research Center, University of Guam, 2009.

Kitson Peter J., "Sustaining the Romantic and Racial Self: Eating People in the 'South Seas'." In Culture of Taste/ Theories of Appetite: Eating Romanticism ed. T. Morton New York: Palgrave MacMillan, 2004, 77-91.

Lafitani, Siosiua F Pouvalu "New Behaviours and Migration since World War II" In Echoes of Pacific War, ed. Niel Gunson, Deryck Scarr, Jennifer Terrell. Canberra: Target Oceania, 1998 76-82.

Lake, Marilyn. "Female Desires: The Meaning of World War II." In Gender and War: Australians at War in the Twentieth Century, ed. Joy Damousi and Marilyn Lake. Cambridge: University of Cambridge, 1995, 60-80. 
Lal, Brij V. "For King and Country: A Talk on the Pacific War in Fiji." In Remembering the Pacific War, ed. Geoffrey M. White. In Remembering the Pacific War, ed. Geoffrey M. White. Honolulu: Center for Pacific Islands Studies, School of Hawaiian, Asian \& Pacific Studies, University of Hawai i at Manoa, 1991, 19-25.

Laracy, Hugh. "George Bogese: Just a Bloody Traitor?" In Remembering the Pacific War, ed. Geoffrey M. White. Honolulu: Center for Pacific Islands Studies, School of Hawaiian, Asian \& Pacific Studies, University of Hawai'i at Manoa, 1991, 14969.

—. "World War Two," in Tides of History: The Pacific Islands in the Twentieth Century, ed. K.R. Howe; Robert C. Kiste and Brij V. Lal. St Leonards: Allen \& Unwin, 1994, 149-169.

Latai, Latu. "Changing Covenants in Samoa? From Brothers and Sisters to Husbands and Wives?". Oceania 85, no. 1 (2015): 92-104.

Lee, Loyd E. ed. World War II in Asia and the Pacific and the War's Aftermath, with General Themes. Westport, Conneticut: Greenwood Press, 1998.

Lerner, Gerda. Why History Matters: Life and Thoughts. New York: Oxford University Press, 1997.

Levesque, Andree. "Prescribers and Rebels: Attitudes to European Women's Sexuality in New Zealand, 1860 - 1916." In Women in History: Essays on European Women in New Zealand, ed. Charlotte Macdonald, Barbara Brookes and Margaret Tennant. Wellington: Allen \& Unwin, 1986.

Liki, Asenati. "Rootedness in 'Aiga: Work and Movement among Teine Uli in Samoa and Aotearoa/ New Zealand." PhD thesis, University of Hawai'i, 2007.

Linnekin, Jocelyn. "The Teacher and His Copra: Debts, Taxes, and Resistance in Colonial Samoa." Ethnohistory 41, no. 4 (Fall 1994): 539-559.

Liua'ana, Ben Featuna'i. "Dragons in Little Paradise: Chinese (Mis-) Fortunes in Samoa, 1900-1950." The Journal of Pacific History 32, no. 1 (1997): 29-48.

—. Samoa Tula'i: Ecclesiastical and Political Face of Samoa's Independence, 1900-1962. Apia, Samoa: Malua Printing Press, 2004.

Longmate, Norman. The G.I.'s. New York: Scribners, 1975.

Loss, Christopher P. "Reading between Enemy Lines: Armed Services Editions and World War II." The Journal of Military History 67, no. 3 (July, 2003): 811-34.

Macdonald, Charlotte. "Taking Colonialism Home: Cook Island "Housegirls" in New

Zealand, 1939-1948." In Colonization and Domestic Service: Historical and Contemporary

Perspectives ed. Victoria K. Haskins and Claire Lowrie. New York: Routledge, Taylor \&

Francis Group, 2015.

Macgregor, Morris J. Integration of the Armed Forces, 1940-1965. Washington: Centre of Military History, 1981.

Macinnis, P. Kokoda Track: 101 Days. Fitzroy: Black Dog Books, 2007.

Mageo, Jeannette. "Spirit Girls and Marines: Possession and Ethnopsychiatry as Historical Discourse in Samoa." American Anthropological Association 23, no. 1 (1996): 61-82.

- Theorizing Self in Samoa: Emotions, Genders and Sexualities. Ann Arbor: University of Michigan Press, 1998.

—."Zones of Ambiguity and Identity Politics in Samoa," Journal of the Royal Anthropological Institute, no. 14 (2008): 61-78.

Mahina-Tuai, Kolokesa "FIA (Forgotten in Action) Pacific Islanders in the New Zealand Armed Forces." In Tangata O Le Moana, ed. Sean Mallon, Kolokesa Mahina-Tuai and Damon Salesa. Wellington: Te Papa Press, 2012. 
Malua Theological College."Malua Theological College History." http://www.malua.edu.ws/History/tabid/4285/Default.aspx.

Manning, Molly Guptill. When Books Went to War. New York: Houghton Mifflin Harcourt Publishing Company, 2014.

Marbaugh, Roland. 'Full Memoirs.' In A Journey with the Marines (www.witnesstowar.org).

Mataia, Louise. "Odd Men from the Pacific: The Participation of Pacific Island Men in the 28 (Maori) Battalion in the Second World War." MA thesis, Otago University, 2007.

Mataia-Milo, Saui'a Louise. "There Are No Commoners in Samoa." In Mothers' Darlings of the South Pacific: The Children of Indigenous Women and U.S. Servicemen, World War II, ed. Judith Bennett and Angela Wanhalla, 42-83. Honolulu: University of Hawai'i Press, 2016.

Mathur, Kanchan. "Body as Space, Body as Site: Bodily Integrity and Women's Empowerment in India." Economic and Political Weekly 43, no. 17 (April 26 - May 2, 2008): 54-63.

Maynard, Stephen Ronald. "Marine Defense Battalions, October 1939-December 1942: Their Contributions in the Early Phases of World War II." MA thesis, University of Texas, 1996.

McLane, John Ryan. "Setting a Barricade against the East Wind: Western Polynesia and the 1918 Influenza Pandemic." PhD thesis, University of Otago, 2012.

Mead, Margaret. Coming of Age in Samoa: A Study of Adolescence and Sex in Primitive Societies. New York: William Morrow, 1928.

- Social Organisation of Manu'a. Honolulu: Bishop Museum, 1930.

Meleisea, Malama. The Making of Modern Samoa. Suva: Institute of Pacific Studies, 1987.

Meleisea, Penelope Schoeffel. "Daughters of Sina: A Study of Gender, Status and Power in Western Samoa." PhD thesis, Australia National University, 1979.

."Women's Associations in the Rural Economy of the South Pacific: Case Studies from Western Samoa and East New Britain Provice, Papua New Guinea." Noumea: South Pacific Commission, 1983.

Meleisea, Malama and Penelope Schoeffel Meleisea, eds. Lagaga: A Short History of Western Samoa Suva: Institute of Pacific Studies, University of the South Pacific, 1987.

Messerschmidt, James W. "The Forgotten Victims of World War II." Violence Against Women 12, no. 7 (2006): 706-712.

M., H. "Samoa." The American Journal of Nursing 14, no. 12 (1914): 1069-73.

Michener, James A. Tales of the South Pacific. New York: Macmillan, 1947.

- The World Is My Home: A Memoir. New York: Curtis Publishing Company, 1992.

Munholland, Kim. Rock of Contention: Free French and Americans at W ar in New Caledonia, 1940-1945. New York: Berghahn Books, 2005.

Munro, Doug and Stewart Firth. "German Labour Policy and the Partition of the Western Pacific: The View From Samoa." The Journal of Pacific History 25, no. 1 (June 1990): 85-102.

Montgomery, Deborah. "Reassessing Rosie: World War II, New Zealand Women and the Iconography of Femininity." Gender and History 8, no. 1 (April, 1996), 108-132.

Moyle, Richard M., ed. The Samoan Journals of John Williams, 1830 and 1832, Pacific History Series No.11. Canberra: Australian National University Press, 1984.

Nabokov, Vladimir. Lolita. Paris: Olympia Press, 1955.

Nelson, Hank. "Kokoda: Pushing the Popular Image." Journal of Pacific History 2010, no. 1 (2010): 89-104. 
Nelson, Olaf Frederick. Misleading the Commission - Samoa at Geneva: A Commentary on the Proceedings of the Permanent Mandates Commission at Its Thirteenth Session Held at Geneva in June, 1928. 1928.

New Zealand Administration of Samoa. "Eighth Report of the Government of New Zealand on the Administration of the Mandated Territory of Western Samoa for the Year Ended the 31st March, 1933.", edited by Pursuant to Article 6 of the Mandate and Article 22 of the Covenant. Prepared by Direction of the Minister of Exterenal Affairs for the information of the League of Nations. Wellington: New Zealand Government, 1933.

Nicole, Robert. Disturbing History: Resistance in Early Colonial Fiji. Honolulu: University of Hawai'i Press, 2011.

O'Brien, Patty. The Pacific Muse: Exotic Femininity and the Colonial Pacific. Seattle: University of Washington Press, 2006.

Paisley, Fiona. "No Back Streets in the Bush: 1920s and the 1930s Pro-Aboriginal White Women's Activism and the Trans-Australia Railway," Australian Feminist Studies 12, no. 25 (1997), 119-137.

Peiss, Kathy. Hope in a Jar: The Making of America's Beauty Culture. New York: Henry Holt and Company Ltd, 1998.

Plimmer, William Neil. "The Military Occupation of Western Samoa, 1914-1920." MA thesis, Victoria University of Wellington, 1966.

Poole, Alexander H. "As Popular as Pin-up Girls: The Armed Services Editions and

American Print Culture, 1943-1947." MA thesis, University of North Carolina at

Chapel Hill, 2009.

Portelli, Alessandro. The Death of Luigi Trastulli and Other Stories: Form and Meaning in Oral History. New York: Stage University of New York Press, 1991.

Potts, E. Daniel and A. Potts. Yanks Down under, 1941-45: the American impact on Australia. Melbourne: Oxford University Press, 1985.

Poyer, Lin, Falgout, Suzanne and Laurence M. Carucci. The Typhoon of War: Micronesian Experiences of the Pacific War. Honolulu: University of Hawaii, 2001.

- Memories of War: Micronesians in the Pacific War. Honolulu: Univesity of Hawaii, 2008.

Provis, Peter. "'Track' or 'Trail'? The Kokoda Debate" Flinders Journal of History and Politics 26 (2010) 127-149.

Ravuvu, Asesela. Fijians at War, 1939-1945. Suva: Institute of Pacific Studies, University of the South Pacific, 1988.

Reid, Julie. "Mythological Representation in Popular Culture Today." Communication Theory and Research 33, no. 2 (2008): 80-98.

Roach, Elizabeth Marchette. "From English Mission to Samoan Congregation: Women and the Church in Rural Western Samoa." PhD thesis, Colombia University, 1984.

Roberts, Mary Louise. What Soldiers Do: Sex and the American GI in World War II France. Chicago: University of Chicago Press, 2013.

Roper, Michael. Masculinity and the British Organization Man since 1945. Oxford: Oxford University Press, 1994.

Salesa, Damon. "Emma and Phebe: Weavers of the Border".Journal of the Polynesian Society 123, no. 2 (2014): 145-67.

. "A Pacific Destiny: New Zealand's Overseas Empire, 1840 - 1945." In Tangata

O Le Moana: New Zealand and the People of the Pacific, ed Kolokesa Mahina-Tuai, Damon Salesa and Sean Mallon. Wellington, New Zealand: Te Papa Press, 2012. 
Racial Crossings: Race, Intermarriage, and the Victorian British Empire. Oxford Historical Monographs. Oxford: Oxford University Press, 2011.

Salesa, Damon. "Troublesome Half-Castes": Tales of a Samoa Borderland." MA thesis, University of Auckland, 1997.

Scarr, Deryck. Ratu Sukuna: Soldier, Statesman, Man of Two Worlds. London: Macmillan 1980.

Scarr, Deryck, Gunson, Niel and Jennifer Terrell, ed., Echoes of Pacific War: Papers from the 7th Tongan History Conference Held in Canberra in January 1997. Canberra: Target Oceania, 1998.

Schoeffel, Penelope. "Gender, Status and Power in Samoa." Canberra Anthropology 1, no. 2 (1978): 69-81.

. "Dilemmas of Modernisation in Primary Health Care in Western Samoa." Social Science \& Medicine 19, no. 3 (1984): 209-16.

. "Rank, Gender and Politics in Ancient Samoa." The Journal of Pacific History 22, no. 4 (1987), 174-193.

Scott, Joan W. "Gender: A Useful Category of Historical Analysis." The American Historical Review 91, no. 5 (December, 1986): 1053-1075.

. "Review: Response to Gordon". Signs 15, no. 4 (1990): 859-60.

. "The Evidence of Experience." Critical Inquiry 17, no. 4 (Summer, 1991): 77397.

. Gender and the Politics of History (New York: Columbia University Press, 1999) . "Storytelling," History and Theory 50, no. 2 (May 2011): 203-09

Sanchez, Pedro Cruz. "Education in American Samoa." PhD thesis, Stanford University, 1956.

Shankman, Paul. "Interethnic Unions and the Regulation of Sex in Colonial Samoa, 1830-1945." Journal of the Polynesian Society 110, no. 2 (2001): 119-47.

. "South Seas Confidential: The Politics of Interethnic Relationships in Colonial Samoa." In Globalization and Culture Change in the Pacific Islands, ed Victoria S. Lockwood. Upper Saddle River, N.J.: Pearson Education, 2004.

Shaw, David Gary. 'Recovering the Self: Agency after Deconstruction,' in Nancy Partner and Sara Foot (eds) The Sage Handbook of Historical Theory. London: Sage, 2013, 474-492.

Simanu-Klutz, Manumaua Luafata. "A Malu I Fale, E Malu Fo'i i Fafo' - Samoan Women and Power: Towards an Historiography of Change and Continuities in Power Relations in Le Nu'u O Teine of Saoluafata 1350 - 1998 C.E." PhD thesis, University of Hawai'i, 2011.

Small, Hilda E.A. Papauta: The Inland Rock. Auckland: LMS, 1967.

So'o, Asofou. Democracy and Custom in Samoa: An uneasy Alliance. Suva: University of the South Pacific, 2008.

Steinmetz, George. The Devil's Handwriting: Precoloniality and the German Colonial State in Qingdao, Samoa, and Southwest Africa. Chicago: University of Chicago Press, 2008.

Stevenson, Robert Louis. A Footnote to History: Eight Years of Trouble in Samoa. $1^{\text {st }}$ ed. 1892. Auckland: Pacifika Press, 1996.

Stoler, Ann. "Making Empire Respectable: The Politics of Race and Morality in 20th Century Colonial Cultures." American Ethnologist 16, no. 4 (1989): 632-60.

Storey, John. An Introduction to Cultural Theory and Popular Culture. Athens: University of Georgia Press, 1998.

-Inventing Popular Culture: From Folklore to Globalization. Malden:Blackwell Publishing, 2003. 
Sturma, Michael. South Sea Maidens: Western Fantasy and Sexual Politics in the South Pacific. Westport: Greenwood Press, 2002.

."Movies under the Sea: Film, Morale, and US Submarines During World War II." The Journal of Popular Culture 47, no. 6 (2014): 1213-25.

Summerfield, Penny. "Gender and War in the Twentieth Century". The International History Review 19, no. 1 (1997): 3-15.

. Reconstructing Women's W artime Lives. Manchester: Manchester University Press, 1998.

. "Culture and Composure: Creating Narratives of the Gendered Self in Oral

History Interviews," Culture and Social History 1 (2004): 65-93.

Sylvester, Christine. Feminist Theory and International Relations in Postmodern Era.

Cambridge: Cambridge University Press, 1994.

Christine Sylvester. War as Experience: Contributions from International Relations and Feminist Analysis. Canada: Routledge, 2012.

Tamura, Keiko. "Japanese Military Nurses in Rabaul." In The Pacific War in Papua New Guinea: Memories and Realities, ed.i Yukio Toyoda and Hank Nelson. Tokyo: Rikkyo University Centre for Asian Area Studies, 2006.

Tauasosi, Tina. "Sauaga O Tamaitai E a Latou Tane i Samoa: Wife Abuse in Samoa." PhD thesis, University of Hawaii, 2010.

Thomas, Nicholas. "Partial Texts: Representation, Colonialism and Agency in Pacific History." The Journal of Pacific History 25, no. 2 (1990): 139-58. -Entangled Objects: Exchange, Material Culture, and Colonialism in the Pacific. Harvard: The President and Fellows of Harvard College, 1991.

Tomkins, Sandra M. "The Influenza Epidemic of 1918-19 in Western Samoa." The Journal of Pacfici History 27, no. 2 (1992): 181-97.

Tosh, John, Stefan Dudink, and Karen Hagemann, ed. Masculinities in Politics and War: Gendering Modern History. Manchester: Manchester University Press, 2004.

Tupuola, Anne Marie. "Learning Sexuality: Young Samoan Women." In Bitter Sweet: Indigenous Women in the Pacific, ed. Phyllis Herda and Tamasailau M. Suaalii Alison Jones. Dunedin: Otago University Press, 2000.

Ulrich, Laurel Thatcher. Well-Behaved Women Seldom Make History. New York: Alfred A. Knopf, 2007.

US War Department. "Sex, Hygiene and Venereal Disease” Pamphlet, September 30, 1942 (Washington, US War Department), http://www.thefewgoodmen.com/thefgmforum/threads/venereal-diseaseprevention-in-ww2.15250/ accessed, 1 December 2016.

Vaai, Emma Kruse. "Sister Patrick's Golden Girls." In Tamaitai Samoa: Their Stories, ed Peggy Fairbairn-Dunlop. Suva: Institute of Pacific Studies, USP, 1996.

Walker, Ranginui. Ka Whawhai Tonu MäTou = Struggle without End. Auckland: Penguin, 2004.

Wanger, Walter. "The Role of Movies in Morale." American Journal of Sociology 47, no. 3 (November 1941): 378-83.

Watkins, Susan Cotts and Angela D. Danzi. "Women's Gossip and Social Change: Childbirth and Fertility Control among Italian and Jewish Women in the United States, 1920-1940." Gender and Society 9, no. 4 (August, 1995): 469-90.

Weeks, Charles J. "The United States Occupation of Tonga, 1942-1945: The Social and Economic Impact," Pacific Historical Review 56, no. 3 (August, 1987): 417-18. 
Wendt, Albert. "Guardians and Wards: A Study of the Origins, Causes, and the First Two Years of the Mau in Western Samoa." MA thesis, Victoria University of Wellington, 1965.

White, Geoffrey M. ed. Remembering the Pacific War. Honolulu: Center for Pacific Islands Studies, School of Hawaiian, Asian and Pacific Studies, 1991.

- Pacific Encounters: Island Memories of World War II. Honolulu: East-West Center, 1987.

White, Geoffrey M. and Lamont Lindstrom ed. The Pacific Theater: Island Representations of World War II. Honolulu: University of Hawaii Press, 1989.

White, Geoffrey M. and Eveline Buchheim. "Travelling War: Memory Practices in Motion." History and Memory 27, no. 2 (2015): 5-19.

Wildenthal, Lora. "Race, Gender and Citizenship in the German Colonial Empire." In Tensions of Empire: Colonial Cultures in a Bourgeois World, ed Frederick Cooper and Ann Stoler. Berkeley: University of California Press, 1997.

Winter, Christine. "Changing Frames." The Journal of Pacific History 47, no. 2 (2012): 34767.

Wood-Ellem, Elizabeth "Behind the Battle Lines: Tonga in World War II in Echoes of Pacific War, ed. Niel Gunson, Deryck Scarr, Jennifer Terrell. Canberra: Target Oceania, 1998.

Queen Salote of Tonga: The Story of An era, 1900-1965. Auckland: Auckland University Press, 1999.

Wood, F. L. W. The New Zealand People at War: Political and External Affairs. Official History of New Zealand in the Second World War 1939-45. Wellington: War History Branch, Department of Internal Affairs, 1958. 